\title{
Sediment Budget for Watersheds of West Maui, Hawaii
}

\section{Scientific Investigations Report 2020-5133}

U.S. Department of the Interior U.S. Geological Survey 
Cover. Photograph of low-intensity trade-wind rainfall over Honokōwai watershed headwaters with agricultural fields of Maui, Hawaii, in the foreground. Photograph by Jonathan Stock on July 20, 2014. 


\section{Sediment Budget for Watersheds of West Maui, Hawaii}

By Jonathan D. Stock and Corina Cerovski-Darriau

Scientific Investigations Report 2020-5133

U.S. Department of the Interior

U.S. Geological Survey 


\section{U.S. Geological Survey, Reston, Virginia: 2021}

For more information on the USGS-the Federal source for science about the Earth, its natural and living resources, natural hazards, and the environment-visit https://www.usgs.gov or call 1-888-ASK-USGS (1-888-275-8747).

For an overview of USGS information products, including maps, imagery, and publications, visit https://www.usgs.gov/pubprod/.

Any use of trade, firm, or product names is for descriptive purposes only and does not imply endorsement by the U.S. Government.

Although this information product, for the most part, is in the public domain, it also may contain copyrighted materials as noted in the text or images protected by State publicity rights. Permission to reproduce copyrighted items or the likeness of a person must be secured from the copyright owner or person whose likeness is being used. Photographs of non-USGS employees in this information product are used with their written consent.

Suggested citation:

Stock, J.D., and Cerovski-Darriau, Corina, 2021, Sediment budget for watersheds of West Maui, Hawaii: U.S. Geological Survey Scientific Investigations Report 2020-5133, 61 p., 1 plate, scale 1:25,000, https://doi.org/10.3133/sir20205133.

ISSN 2328-0328 (online) 


\section{Contents}

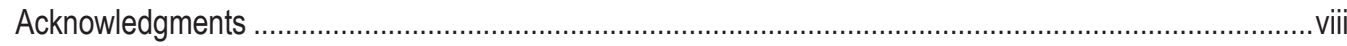

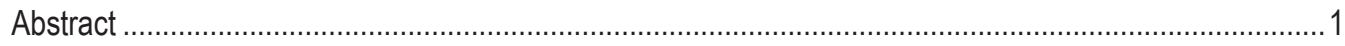

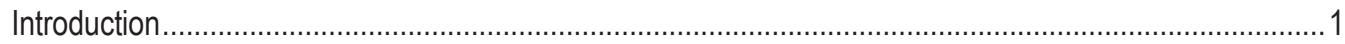

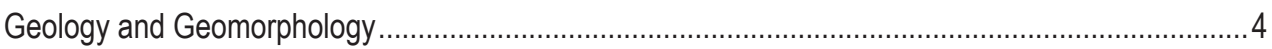

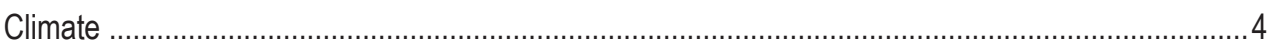

Geomorphic Processes in West Maui Watersheds................................................................ 5

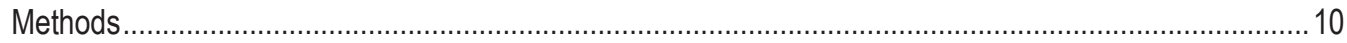

Infiltration and Particle-Size Analysis ................................................................................. 10

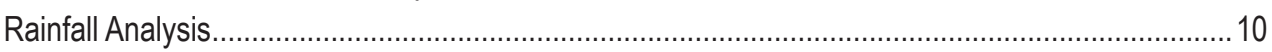

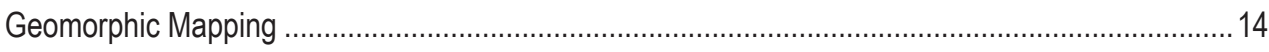

Survey of Historic Fill Terraces ............................................................................................ 14

Measuring Hydraulic Geometry and Monitoring Representative Bank-Erosion Rates ..................... 16

Testing Resistance of Bank Material....................................................................................... 18

Reconnaissance Sediment Budget................................................................................. 19

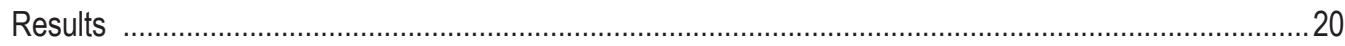

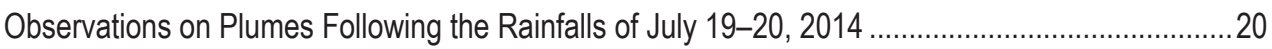

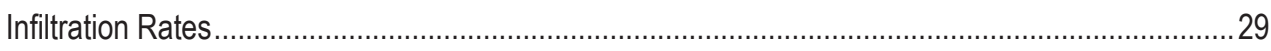

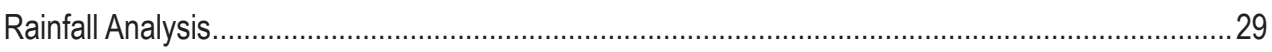

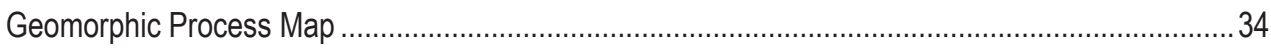

Hydraulic Geometry and Extent and Rate of Bank Erosion ....................................................... 38

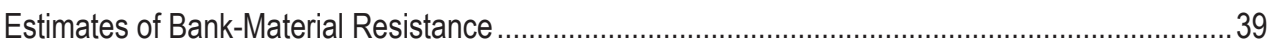

Reconnaissance Sediment Budgets for West Maui Watersheds................................................. 44

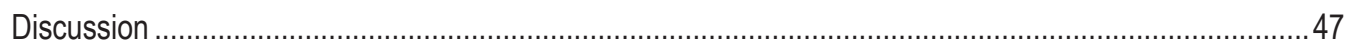

Conditions and Source of Annual Sediment Plumes ................................................................ 47

Evaluating Sediment Budgets............................................................................................ 47

Potential Tool for Prioritizing In-stream Mitigation................................................................... 51

Long-Term Sediment Sources from Large Landslides..........................................................53

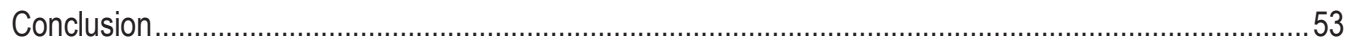

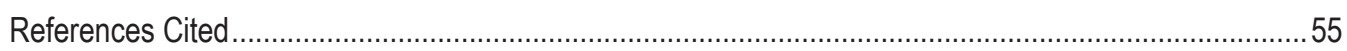

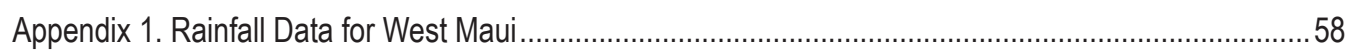

\section{Figures}

1. Photographs showing nearshore sediment pollution from terrestrial runoff in West Maui, September 14-15, 2016

2. Map showing geology and major watersheds of West Maui draped over shaded-relief topography......

3. Photographs showing sediments overlying Honolua Volcanic flows. A, Fine-grained sand and silt deposits overlying flows of the Honolua Volcanics in the vicinity of Ka'anapali Coffee Farms, Kaanapali watershed. B, Quarry wall exposure of flows of the Honolua Volcanics capped by bouldery alluvium .

4. Photographs showing gravity-driven hillslope geomorphic processes of West Maui. $A$, Closed-canopy forests in headwaters, where sediment transport is characterized by slow, episodic soil creep. $B$, Example of soil creep from tree throw in headwaters of Mokupe'a valley. $C$, Soil-mantled slope abutting stream, with feral pig activity moving dark, organic- 
rich soil into channel to right. $D$, Hillslopes characterized by rockfall processes, north of Honokōwai-upper rain gage. $E$, Weathered boulder showing impact marks from recent rockfall transport to Honokōwai Stream bed. F, Angular boulders deposited as talus by rockfall processes

5. Photographs showing fluid-driven hillslope geomorphic processes in West Maui. $A$, Channelized Horton overland flow from rains on July 19-20, 2014. B, Horton overland flow focused into rills on exposed saprolite of Honolua Volcanics. C, Sediment deposited by Horton overland flow in water-bar area of former agricultural fields. $D$, Dashed line shows contact between fine sediments with plastic drip tape pushed over in-place soils with peds. $E$, Ridge between Honolua Stream and Pāpua Gulch, showing sidecast layer removed by shallow landsliding and overland flow. F, Enlargement of sidecast, illustrating nonsorted deposit with fragments of burned shrubs concentrated near its base...

6. Historic deposits of fine sediment from agricultural practices near Wahikuli Gulch

7. Photographs showing valley geomorphic processes in West Maui. $A$, Gravel-bedded stream typical of fluvial sediment transport down slopes of $0.01-0.08$ in valleys of West Maui. $B$, Unsorted terrace sediments without imbrication, likely deposited by debris flows, mobile at slopes greater than about $0.03-0.05$. C, Sorted, imbricated deposits of a fluvial terrace above dashed white line. $D$, Fine sands, silts, and clays deposited as a historic fill terrace above Honokōwai sediment impoundment basin. E, Fill terrace of fine sediments overlying gravel deposits that are characteristic of West Maui's gravel-bedded streams with slopes of 0.010.08 . $F$, Historicfill terrace, upstream of $D$, with embedded 1970 s plastic drip tape from fieldirrigation system.

8. Historical artifacts embedded in fill terraces. A, Liquor bottle whose base stamp of Owens-lllinois Glass Co. indicates manufacture in 1954. B, Small glass vial from Honolua Stream fill terrace, likely a c.1900 opium container .....

9. Map showing locations of field tests and instrumentation in West Maui.

10. Photographs showing examples of infiltration-test sites at locations shown in figure 9. $A$, Unimproved road south of Honokōwai Stream with evidence of minor runoff from July 19-20, 2014, rainfalls. $B$, Trace evidence for road runoff on former agricultural fields south of Wahikuli Gulch but not for field runoff from July 19-20, 2014, rainfalls; site of md9-10 hydraulic conductivity tests

11. Orthophotographs of West Maui in 1951, illustrating pineapple and sugar-cane agricultural fields (unit ofa) and high-albedo sidecast cascading down the sideslopes (unit ss) due to former agricultural practices. A, Map showing location of maps $B-E$. B, Pineapple fields (unit ofa) with sidecast as high-albedo patches on valley walls. C, Fallow agricultural fields unit ofa) bounded by canopied forest with soil creep (unit scc). $D$, Contrasting patterns of pineapple and sugar-cane fields. $E$, Boundary of fallow agricultural fields with soil creep under forest canopy. Images $B-E$ show the source areas of fine sediments that were pushed into the valleys while shaping sugar-cane (unit sc) and pineapple (unit $p$ ) fields

12. Bank erosion monitoring sites in West Maui. Each reach is relatively straight, bordered by a brown, fine-grained fill terrace. Gulches in Pāpua $(A, B)$ and Māhinahina $(C)$ are ephemeral. $D$. Honolua Stream runs intermittently.

13. Cross sections of the stream channels, shown in figure 12, where we installed erosion pins to measure bank erosion. Solid black lines show field estimates of bankfull flow. Channel walls in these figures are composed of silts and fine sands from historic fill terraces.

14. Illustration of Partrec's cohesive strength meter deployed at $A$, Wahikuli Gulch fill terrace and $B$, 'Tao Stream, to characterize debris-flow-deposit matrix for a related project. $A$, The air tank along left edge pressurizes an internal water reservoir, which the instrument pumps to a jet nozzle inside the gray cup in the bucket. $B$, Test area

15. Plots of West Maui rainfall. $A$, Cumulative rainfalls for West Maui. $B$, Rainfall intensities at 10-minute discretization recorded by tipping-bucket gages during the storm of July 19-20, 2014 
16. Plot showing cumulative exceedance rainfall intensities for tipping-bucket gages

17. Four plots of hourly rainfall intensity for tipping-bucket rain gages in West Maui from May 2014 to October 2016: A, upper Honokōwai watershed; $B$, middle Honokōwai watershed; $C$, lower Honokōwai watershed; $D$, Kaanapali Stream watershed.

18. Map showing locations of coastal plumes observed by Stock on July 20, 2014, 13:00-18:00 HST (Hawaii Standard Time) .....

19. Photographs of West Maui coastal plumes observed July 20, 2014, 13:00-18:00 Hawaii Standard Time $(A-K)$ and July $30(L)$. A, Looking east of Keonehelelee. B, Looking west of Keonehelelee. C, Honolua Bay. D, Honokahua Bay. E, D.T. Fleming Beach Park. F, Nāpili Bay. G, Ka'ōpala outlet looking north. $H$, Ka'ōpala outlet looking south. I, Ka'ea Point looking north. J, Kahana Stream outlet. K, Honokōwai Stream outlet. L, Looking south from Honokōwai

20. Map showing locations of stream-sediment pollution observed by Stock on July 20, 2014, 13:00-18:00 Hawaii Standard Time, following the July 19-20 storm

21. Photographs of suspended sediment in West Maui streams, observed July 20, 2014, 13:00 18:00 Hawaii Standard Time. A, Honokōhau Stream. B, Pūnahā Gulch. C, Pōhakupule Gulch. $D$, Honolua Stream. $E$, Unnamed tributary to Honolua Bay near Honokohau Street. F, Kahauiki Gulch. G, Confluence of Honokahua Stream and Mokupe'a Gulch. H, Tributary gulch to Nāpili Bay. I, Tributary gulch to Honokeana Bay. J, Ka'ōpala Gulch outlet. K, Kahana Stream. L, Honokōwai Stream; M, Hāhākea Gulch outlet 10 m up from coast. $N$, Kahoma Stream from Front Street bridge in Lahaina.

22. USDA soil classification diagram of potential plume sediment sources, including airfall from agricultural fields and historic fill terraces in watersheds

23. Plot of particle-size distributions of surface soils from infiltration test sites on fields and roads of West Maui and historic fill terraces

24. Historic rainfall data from West Maui gages, plotted by water year (starts on October 1 )........33

25. Plot showing the number of hours of rainfall above a given intensity for historic rain gages in West Maui

26. Plot showing occurrence of largest storms in West Maui uplands since 1978

27. Plots showing the number of hours of rainfall above a given intensity for the larger storms over the record of Field $46(A)$ and Puu Kolii $(B)$.....

28. Plots of recurrence intervals for 1-hour rainfall intensities $(A)$ and 2-hour rainfall intensities $(B)$ in West Maui

29. Area of each geomorphic process as a percentage of total map area

30. Hydraulic geometry and grain size for selected channels in West Maui, including erosion-pin cross-section locations. Channel dimensions of $A$, hydraulic radius $\mathrm{R}$, and $B$, bankfull width $W$, grow downstream with drainage area $A$ at rates that are comparable to channels elsewhere. In $C$, the coarser particles that characterize grain resistance to flow (d84, or 84 percent of grains are finer) decrease as drainage area increases. We use the hydraulic geometry to estimate reach-averaged shear stresses for bankfull flow in West Maui valleys, with the notion that this value might be a very crude proxy for bank erosion rates

31. Bank erosion of historic fill terraces, West Maui. $A$, Pāpua 1 detail; $B$, Pāpua 2 detail; $C$, Honolua; $D$, Māhinahina detail

32. Map of West Maui showing watershed areas that are entirely upstream of agricultural influence, locations of surveyed historic fill terraces, numbered watersheds of table 6 , and pie charts showing the annualized sediment budget from the largest of the numbered watersheds, as reported in table 6 .

33. Distributions of $A$, measured heights, and $B$, visual estimates of the amount of coarse material (for example, larger than sand) in historic fill-terrace material of West Maui 
34. Lowering rates of historic fill terraces measured over a year, West Maui, Hawaii. Lowering rates in the higher annual rainfall (wet side) channels of Honolua Stream $(A)$, and its tributary Pāpua Gulch (B, Pāpua 1; C, Pāpua 2), are much higher than those found at Māhinahina gulch $(D)$.

35. A, Bank lowering rates merged for the three higher-rainfall sites (wet side) in West Maui, and $B$, the log-transformed distribution.

36. Plots showing the decline in water clarity (transmission) as increasing Partrac Cohesive Strength Meter (CSM) jet pressures erodes bank materials. A, 'Tao Stream, with low and high values for the same test area bracketing a fine-sand airfall test result, shown for comparison. B, Bank materials from West Maui's historic fill terraces.

37. Illustration of the annual fine-sediment load to the nearshore from each watershed in West Maui

38. Planet satellite imagery over West Maui showing December 22, 2017, nearshore plume (A) and interpreted plume boundary and sources $(B)$......

39. Illustration of simple three-cell longshore aggregation model for sediment pollution, showing longshore accumulation in metric tons, based on plume behavior

40. Published erosion rates for the Islands of Kaua'i, O'ahu, Moloka'i, Lāna'i, and Hawai'i, expressed as the lowering rate of a $950 \mathrm{~kg} / \mathrm{m}^{3}$ bulk-density soil.

41. Map of reach-averaged shear stress estimated for Ka'ōpala Gulch using hydraulic geometry and the 10-meter USGS digital elevation model (DEM)

42. Example of a simple model for bank inundation throughout West Maui's streams, based on correlating rainfall intensity with flow depth at a given drainage area and using hydraulic geometry to extend the correlation through the stream network......

\section{Tables}

1. Characteristics of selected National Weather Service rain gages, West Maui ..........................13

2. Surface lowering rates used in reconnaissance sediment budget...

3. Matrix infiltration estimates of saturated hydraulic conductivity $\left(\mathrm{K}_{\text {sat }}\right)$ and

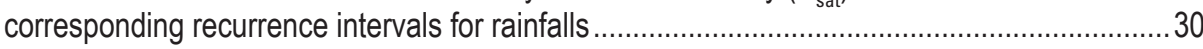

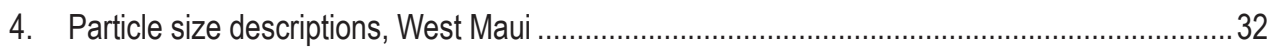

5. Recurrence intervals for exceedance rainfalls at Field 46 and Lahaina ..................................35

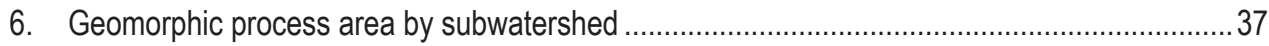

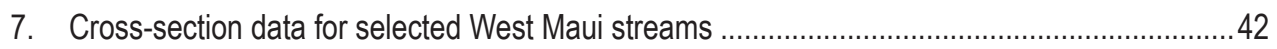

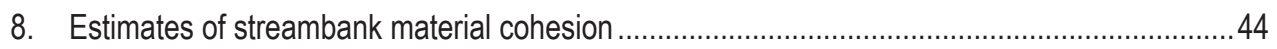

9. Sediment budget for bank erosion of historic fill terraces, West Maui ..................................... 45

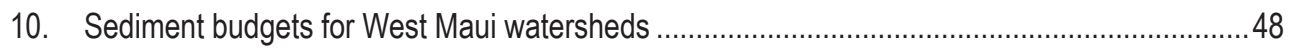

11. Compilation of estimates of Hawaiian lowering rates ...........................................................51

\section{Appendix Tables}

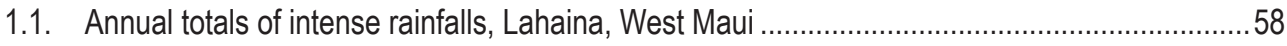

1.2. Annual totals of intense rainfalls, Puu Kolii, West Maui....................................................... 58

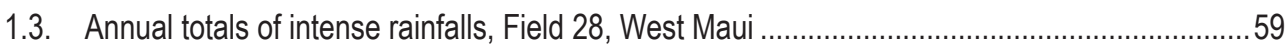

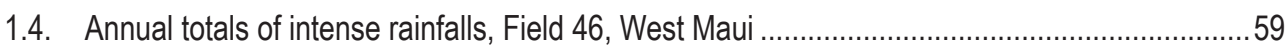

1.5. Record of heaviest rainfalls over 1 hour in Lahaina, West Maui ..........................................60

1.6. Record of heaviest rainfalls over 1 hour in Puu Kolii, West Maui ...........................................6 60

1.7. Record of heaviest rainfalls over 1 hour in Field 28, West Maui ............................................60

1.8. Record of heaviest rainfalls over 1 hour in Field 46, West Maui .......................................... 61 


\section{Plate}

Geomorphic Processes for Watersheds of West Maui, Maui County, Hawaii....https://doi.org/10.3133/sir20205133

\section{Conversion Factors}

International System of Units to U.S. customary units

\begin{tabular}{|c|c|c|}
\hline Multiply & By & To obtain \\
\hline \multicolumn{3}{|c|}{ Length } \\
\hline centimeter $(\mathrm{cm})$ & 0.3937 & inch (in.) \\
\hline millimeter (mm) & 0.03937 & inch (in.) \\
\hline meter $(\mathrm{m})$ & 3.281 & foot $(\mathrm{ft})$ \\
\hline kilometer $(\mathrm{km})$ & 0.6214 & mile (mi) \\
\hline meter $(\mathrm{m})$ & 1.094 & yard (yd) \\
\hline \multicolumn{3}{|c|}{ Area } \\
\hline square meter $\left(\mathrm{m}^{2}\right)$ & 0.0002471 & acre \\
\hline square kilometer $\left(\mathrm{km}^{2}\right)$ & 247.1 & acre \\
\hline square meter $\left(\mathrm{m}^{2}\right)$ & 10.76 & square foot $\left(\mathrm{ft}^{2}\right)$ \\
\hline square kilometer $\left(\mathrm{km}^{2}\right)$ & 0.3861 & square mile $\left(\mathrm{mi}^{2}\right)$ \\
\hline \multicolumn{3}{|c|}{ Volume } \\
\hline cubic meter $\left(\mathrm{m}^{3}\right)$ & 264.2 & gallon (gal) \\
\hline cubic meter $\left(\mathrm{m}^{3}\right)$ & 0.0002642 & million gallons (Mgal) \\
\hline cubic meter $\left(\mathrm{m}^{3}\right)$ & 35.31 & cubic foot $\left(\mathrm{ft}^{3}\right)$ \\
\hline cubic meter $\left(\mathrm{m}^{3}\right)$ & 1.308 & cubic yard $\left(\mathrm{yd}^{3}\right)$ \\
\hline cubic meter $\left(\mathrm{m}^{3}\right)$ & 0.0008107 & acre-foot (acre-ft) \\
\hline \multicolumn{3}{|c|}{ Rate } \\
\hline millimeter per hour $(\mathrm{mm} / \mathrm{hr})$ & 0.03937 & inch per hour (in/h) \\
\hline millimeter per year (mm/yr) & 0.03937 & inch per year (in/yr) \\
\hline \multicolumn{3}{|c|}{ Mass } \\
\hline kilogram (kg) & 2.205 & pound avoirdupois (lb) \\
\hline metric ton per year & 1.102 & ton per year (ton/yr) \\
\hline \multicolumn{3}{|c|}{ Density } \\
\hline kilogram per cubic meter $\left(\mathrm{kg} / \mathrm{m}^{3}\right)$ & 0.06242 & pound per cubic foot $\left(\mathrm{lb} / \mathrm{ft}^{3}\right)$ \\
\hline
\end{tabular}

Slope in radians ( $\alpha$ rad) may be converted to degrees $\left(a^{0}\right)$ as $\alpha^{0}=\arctan (\alpha \operatorname{rad})$ 


\section{Acknowledgments}

This work could not have been accomplished without a large number of collaborators, both in the field and in the lab. Photographs of partners to whom we are grateful for fieldwork are included below. We thank the U.S. Army Corps of Engineers (USACE) for support for field work from Military Interdepartmental Purchase Requests WX3JR941678572 and WX3JR951112223. USACE staff-Mitchell Moore, James Selegean, and Jessica Wiggsprovided reviews and field support. We thank the U.S. Geological Survey (USGS) National Cooperative Geologic Mapping Program for salary support for Cerovski-Darriau. Michelle Haynes (International Water Research) and Kim Falinski (The Nature Conservancy) supported us through field work and good guidance. We thank the USGS Pacific Coral Reefs project for rain-gage and other equipment grants. Pōmaika'l Kaniaupio-Crozier, Conservation manager for Pu'u Kukui Watershed Preserve, and his colleagues Hookahi Alves, Garrett Ancheta, Bryson Keonipaa Anoba, Dave Bryan, Donna Borge, Herb Coyle, Kainoa Pestana, Marcus Koa Range, and Daniel Tanaka provided logistical support, field work, and their wisdom about the landscape. We are deeply grateful for their hard work and contribution to our investigations. Tova Callender, West Maui Watershed Coordinator, introduced us to the field area and provided logistical support, field work, and much wisdom. Coral Reef Alliance staff, Wes Crile and Chana Ane, provided field help and were a great source of inspiration and good ideas. Professor Kirsten Oleson and students, Megan Barnes and Cecilia Le Viol, at University of Hawaii, Mānoa, helped with field work and brought their own good insights. Ron Rickman from the USGS Pacific Islands Water Science Center provided suspendedsediment data for Hawaiian streams. Ross Winans from National Oceanic and Atmospheric Administration (NOAA) scanned and orthorectified the 1951 orthoimagery of West Maui, which proved vital for mapping historic deposits of modified soil. We thank Maui Land and Pineapple Company, Department of Hawaiian Homelands, and Hawaii Department of Land and Natural Resources for enabling land access. Chris Brosius and the rest of the West Maui Mountain Watershed Partnership staff provided facilities, logistical support, and back-country access. An early and exhaustive review by Patrick Muffler (USGS) dramatically improved this manuscript. We thank Oliver Chadwick (University of California, Santa Barbara) and Katherine Skalak, Mark Landers, Amy East, and Alan Gellis (USGS) for helpful reviews. Errors are the responsibility of the first author. 
Tova Callender

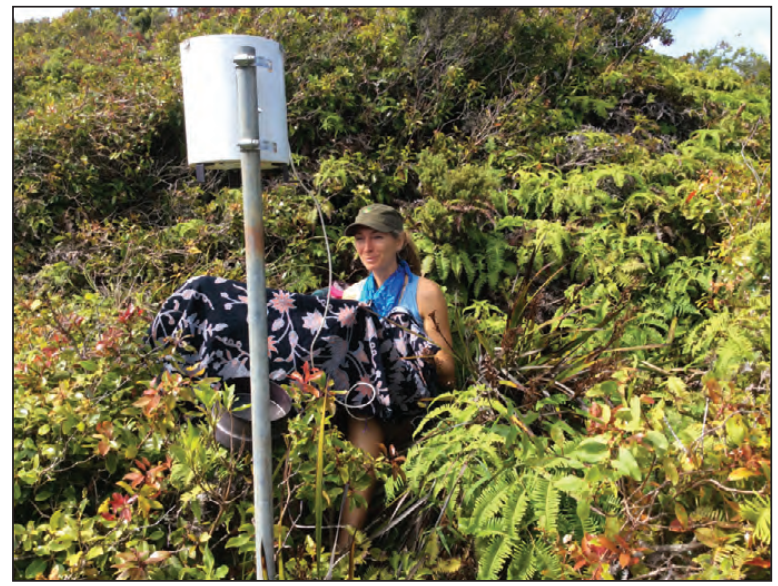

Chris Brosius

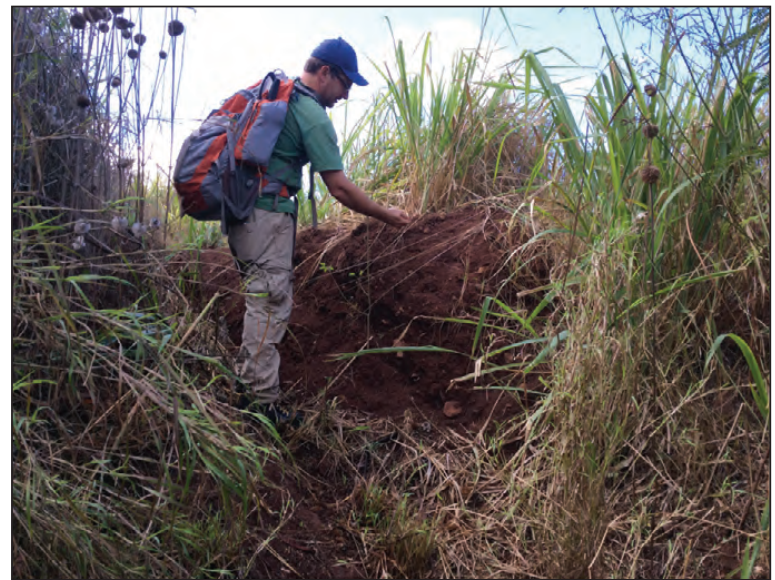

Corina Cerovski-Darriau and Marcus Koa Range

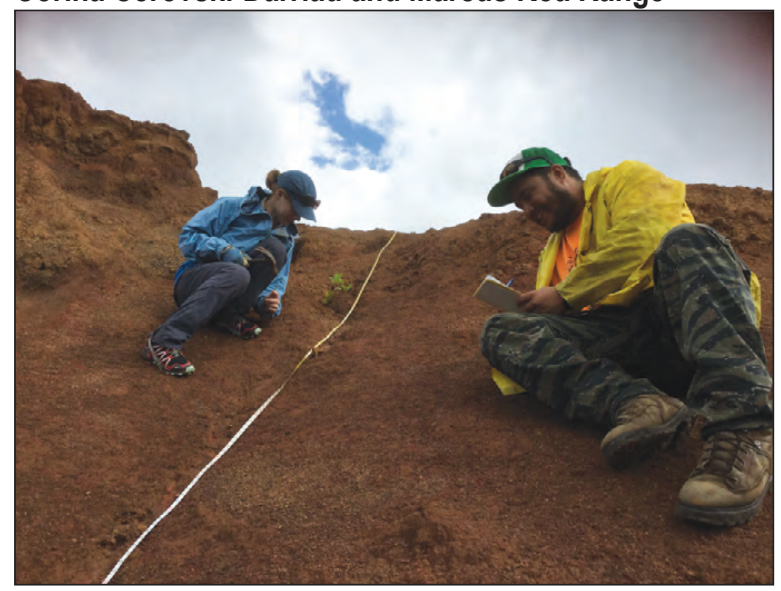

Kim Falinski

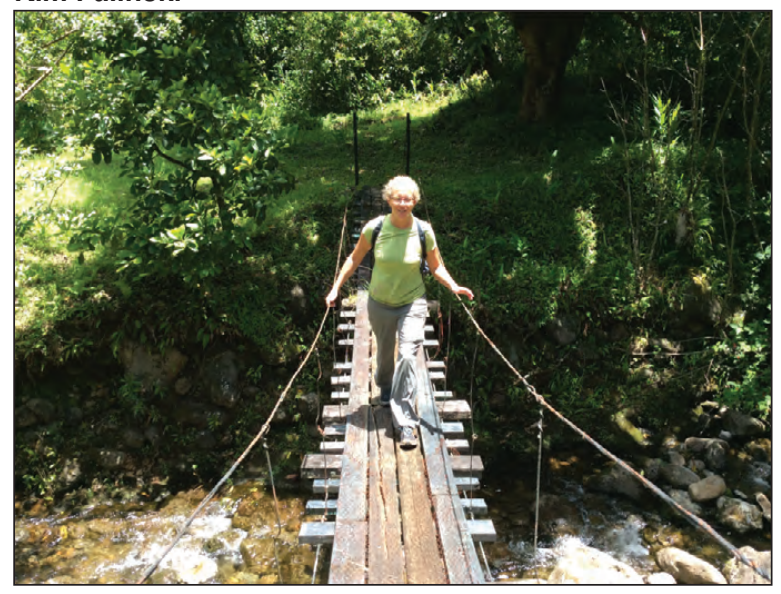

Wesley Crile

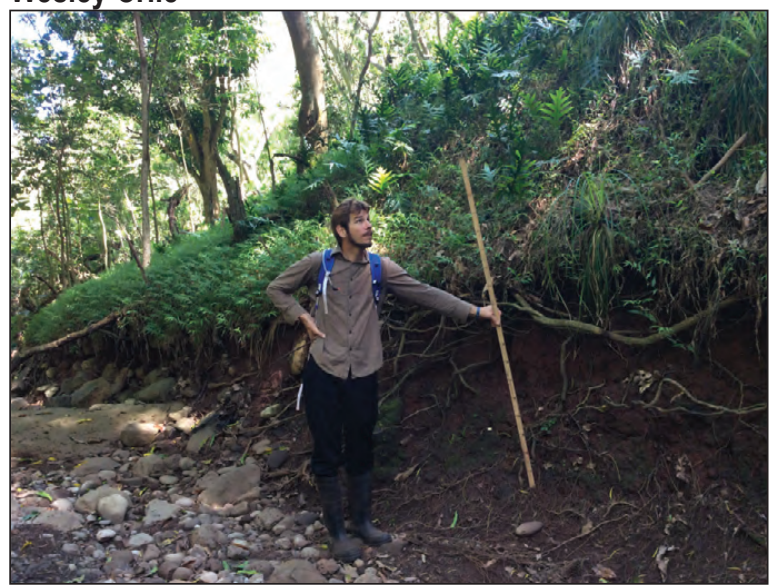

Bryson Keonipaa Anoba

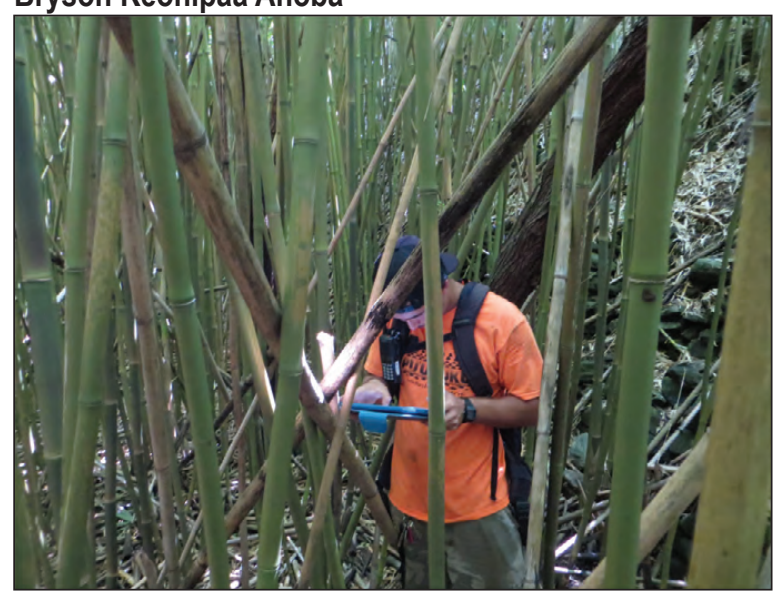


Garrett Ancheta

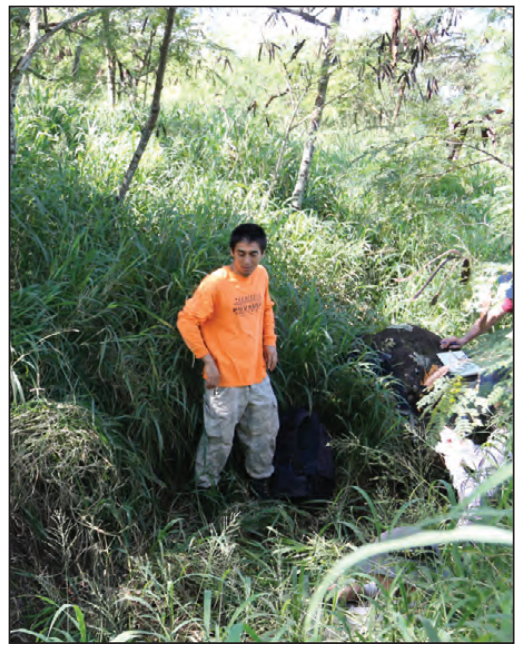

Megan Barnes

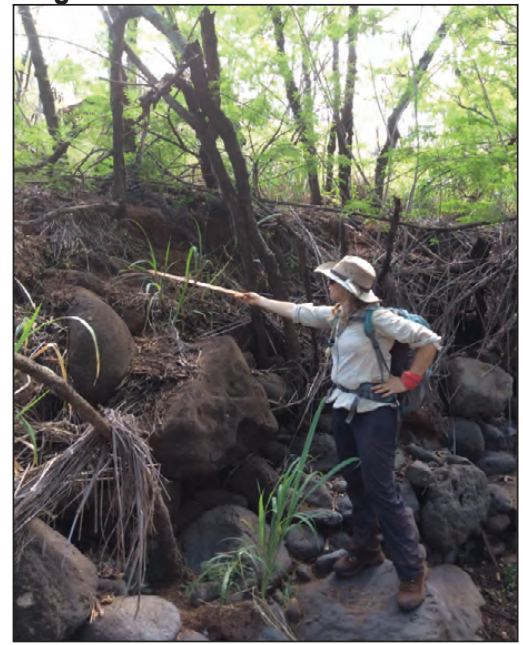

Daniel Tanaka

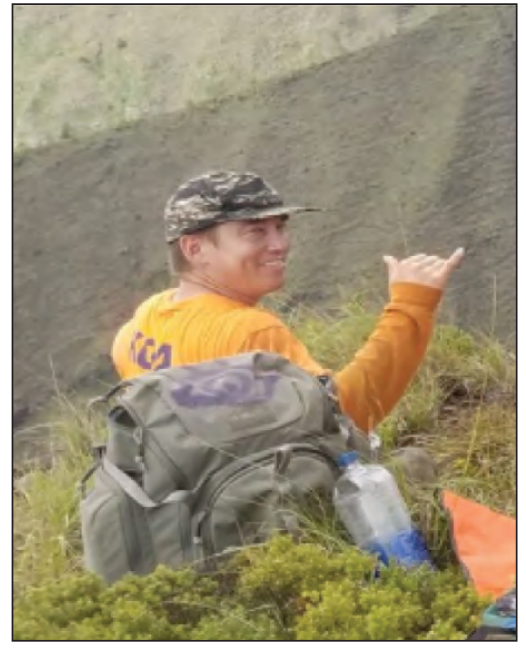

Pōmaika'i Kaniaupio-Crozier and Crile

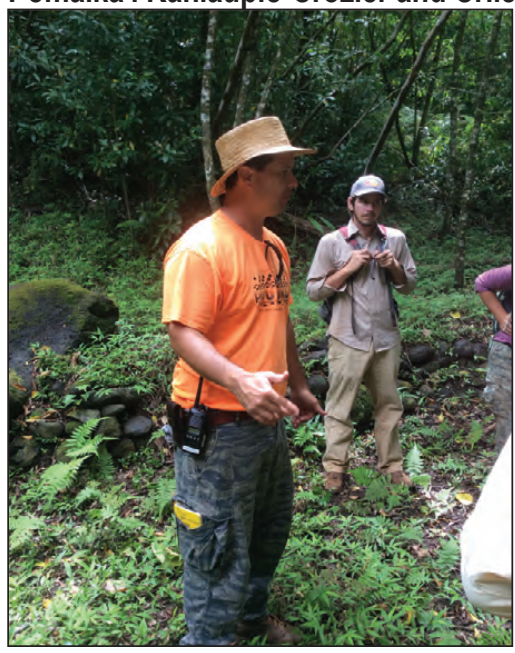

J. Wiggs, J. Selegean, and C. Ane

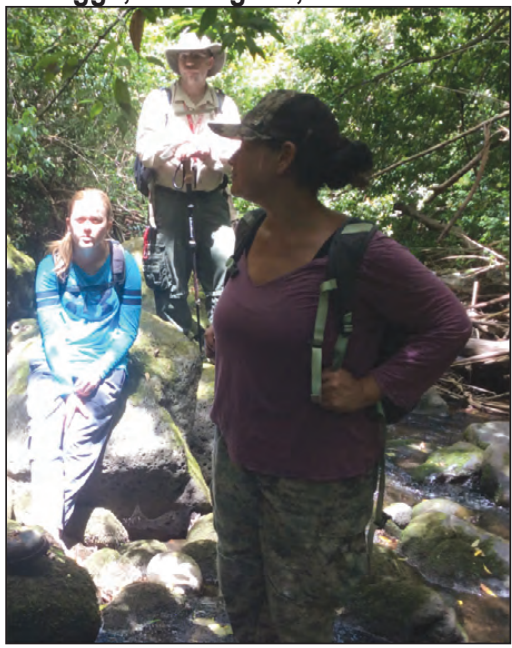

Mitchell Moore

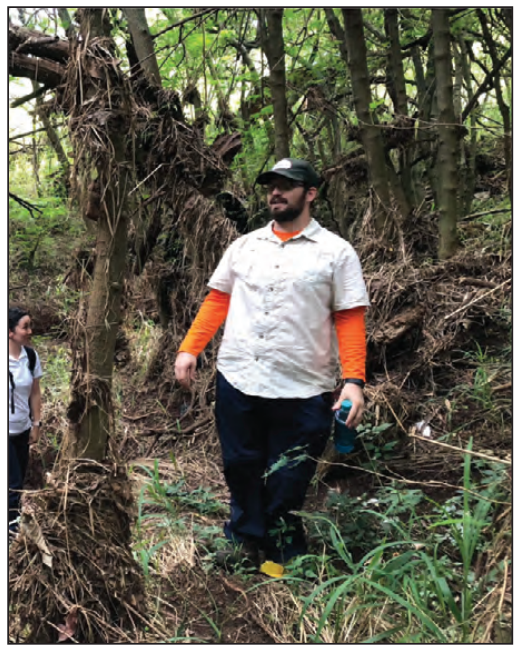

Cerovski-Darriau and Michelle Haynes
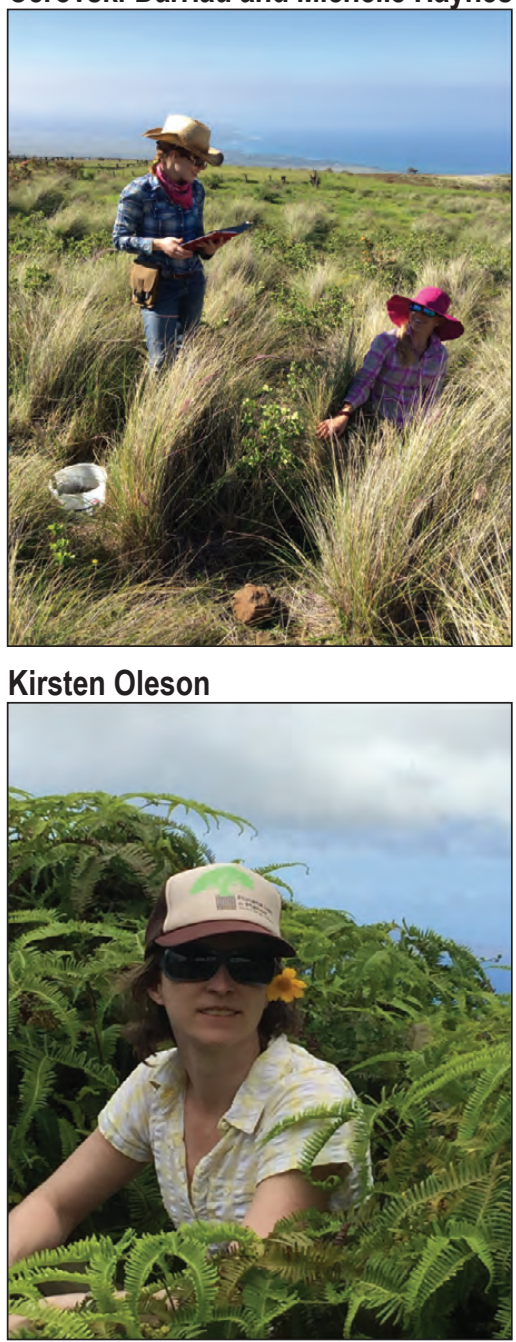

Kainoa Pestana

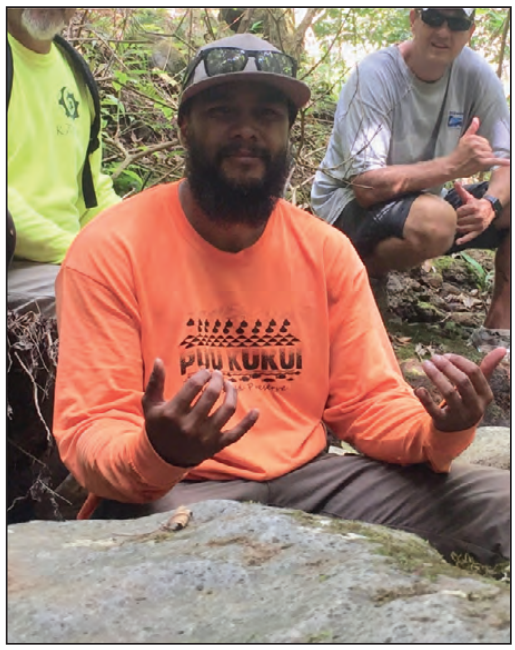


Hookahi Alves

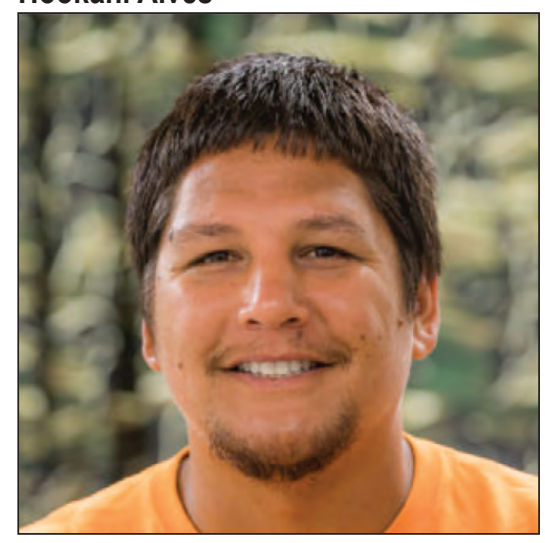

Herb Coyle

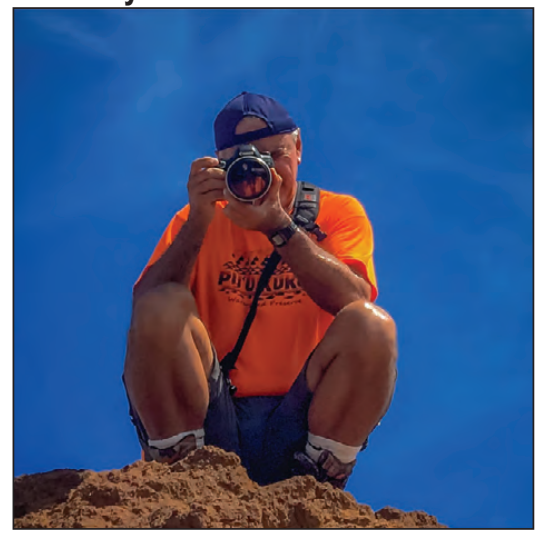

Cecilia Le Viol

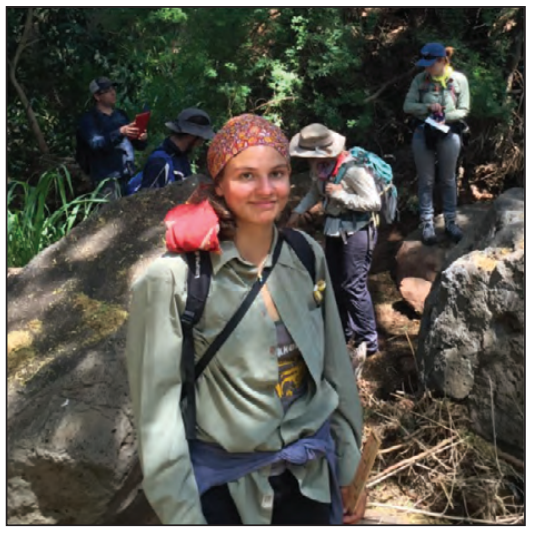





\title{
Sediment Budget for Watersheds of West Maui, Hawaii
}

\author{
By Jonathan D. Stock and Corina Cerovski-Darriau
}

\section{Abstract}

Episodic runoff brings suspended sediment to West Maui's nearshore waters, turning them from blue to brown. This pollution degrades the ecological, cultural, and recreational value of these iconic nearshore waters. We used mapping, monitoring, and modeling to identify and quantify the watershed sources for fine sediment that pollutes the nearshore each year. These results focus strategies to reduce pollution on the outstanding sources for this sediment.

Terrestrial runoff causing coastal plumes now occurs when two or more hours of rain falls at rates greater than 10-20 millimeter $(\mathrm{mm})$ per hour in source watersheds. Analysis of recent and historical rainfall indicates that West Maui communities can expect rainfalls to bring coastal plumes at least 3-5 times per year. Former agricultural fields and some unimproved roads are possible sources for the fine sediment of these plumes. We found, however, that these obvious sources do not produce plumes during small annual storms, because they drain water at rates that far exceed most annual rainfalls and because there is no evidence for runoff from rains that caused recent plumes. Streambanks now eroding into historic fill terraces of sands, silts, and clays are a more plausible source. These terraces are found only downstream of historical agricultural fields and are composed of silt and fine sand. Surveys show that the fill terraces occupy $\sim 40$ percent of streambank length, making them extensive. During 2015-2016, these deposits eroded at median rates of 5-24 mm per year. Summed over West Maui's watersheds, these rates imply sediment loads carried to the coast that can be ten times or more than modeled pre-human values. A sediment budget indicates that bank erosion of fill terraces from a few watersheds likely dominates the current annual finesediment load to the nearshore, with Kahana Stream watershed producing the largest annual input of 285 metric tons, the equivalent of 29 dump-truck loads every year.

Although past large storms have contributed to sediment loading, annual plume generation is now caused by smaller rainfalls eroding these near-stream terrace deposits, a legacy of historic agriculture. Treatments of former agricultural fields, roads, and reserve forests are consequently not likely to measurably effect sediment pollution from smaller, more frequent storms. Increased runoff from residential and commercial development of West Maui has the potential to exacerbate sediment plumes from such storms.

\section{Introduction}

Coral ecosystems of west Maui have ecological, cultural, and recreational value. The clean nearshore waters necessary for coral support a tourism enterprise whose revenue is essential to local communities, and the same reefs help reduce coastal erosion from storms (Storlazzi and others, 2017). This enterprise is increasingly under threat from global climate change, marine-resource use, and local land-based pollution (fig. 1). Sediment, nutrients, and other pollutants are now transported to Maui's coastal waters in runoff, groundwater seepage, and atmospheric fallout. Terrestrial sediment degrades coral ecosystems by blocking light used for photosynthesis and coral growth (for example, Davies, 1991; Anthony and Connolly, 2004; Storlazzi and others, 2015), inhibiting coral larval recruitment (for example, Gilmour, 1999; Perez and others, 2014; Jokiel and others, 2014), smothering and abrading coral (for example, Edmonson, 1928; Fabricius, 2005), and triggering increases in macroalgae (for example, Weber and others, 2012; Jokiel and others, 2014). On July 19-20, 2014, we witnessed coastal plumes of fine sediment along Maui's western shores, delivered by terrestrial runoff from a small storm. These events, once thought to be unusual, now occur many times each year. Although this kind of pollution is one of many factors threatening the survival of coral reefs and nearshore ecosystems, it is the factor that Maui's communities can influence profoundly. But first these communities need to know where the pollution is coming from.

To determine pollution sources, we used mapping, field experiments, monitoring, and data analysis to create a sediment budget that estimates the annual export of fine sediment (clays, silts, and sands) from the watersheds collectively known as the West Maui Watersheds (fig. 2). This region will hereafter be referred to as "West Maui." A sediment budget quantifies the sources, storage, and export of sediment from a watershed or other bounded area (Dietrich and Dunne, 1978; Dietrich and others, 1982; Reid and Dunne, 1996) over a designated time interval. There are many different applications of this concept, so sediment budgets "vary widely in scope, approach and methods" (Reid and Dunne, 2016). Our goal is to enable users to focus mitigation on mapped fine-sediment sources that most impact annual nearshore sediment pollution. To accomplish this end, we estimate finesediment supply by mapping geomorphic processes across West Maui's watersheds and estimating or measuring the rate 


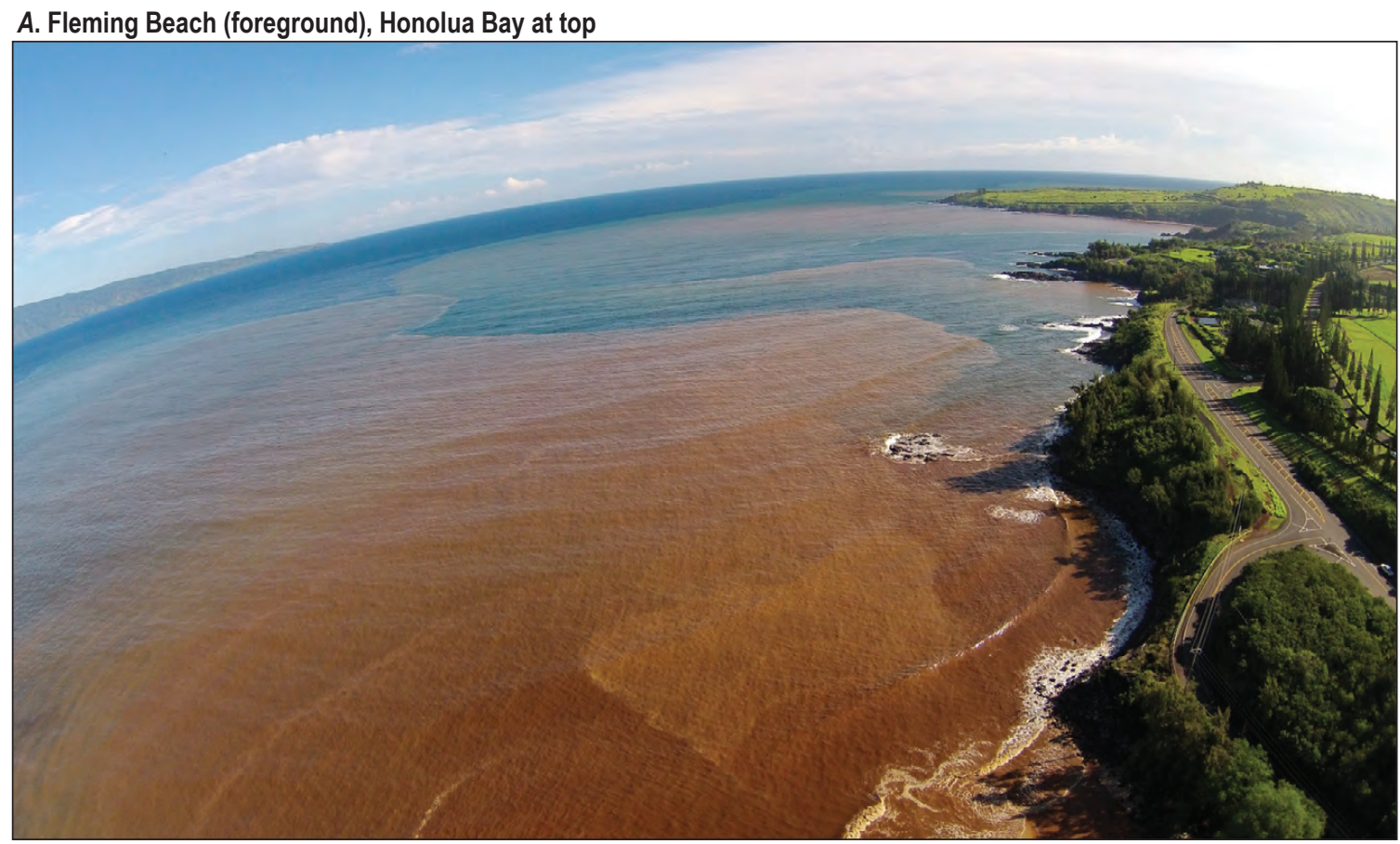

\section{B. Honolua Bay}

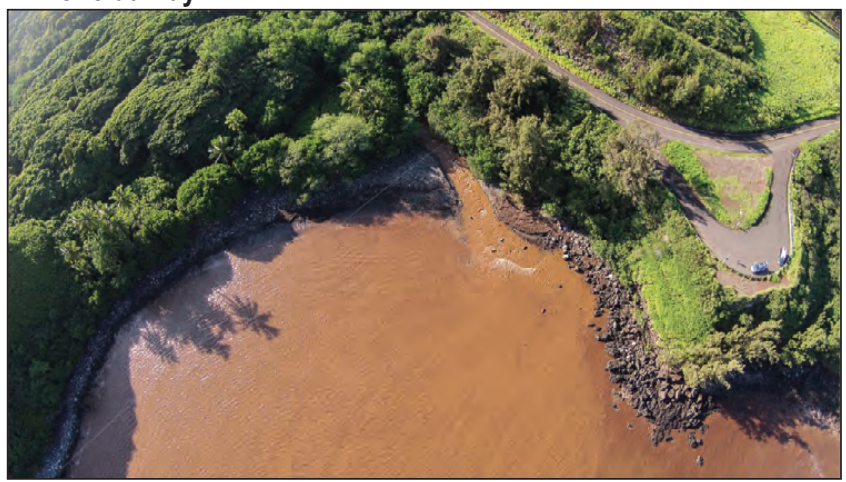

\section{Honokōwai looking south}

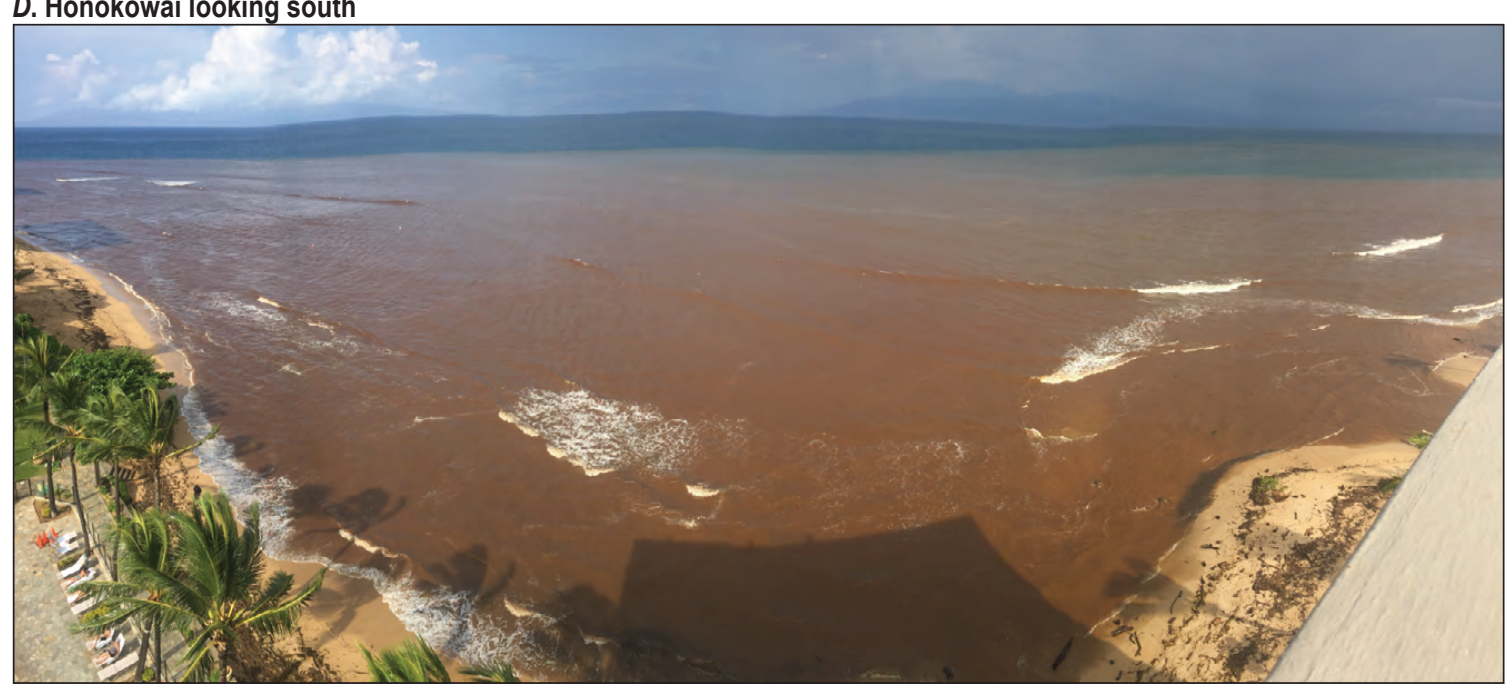

Figure 1. Photographs showing nearshore sediment pollution from terrestrial runoff in West Maui, September 14-15, 2016. Continued pollution risks the ecological, cultural, and economic value of these iconic West Maui sites. Images courtesy of Bill Rathfon, private citizen.

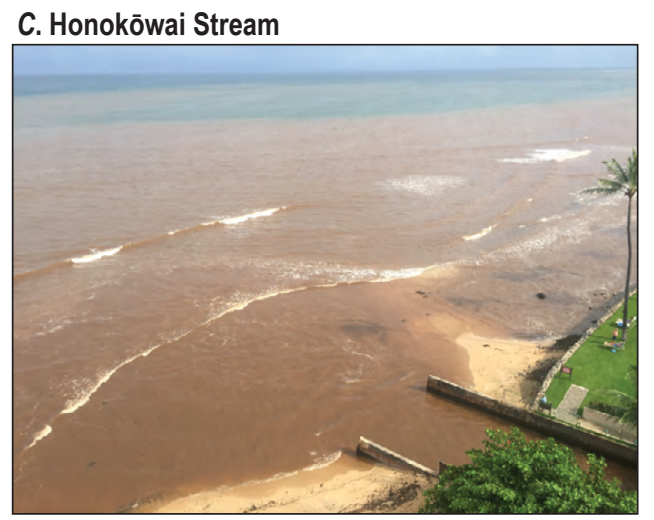




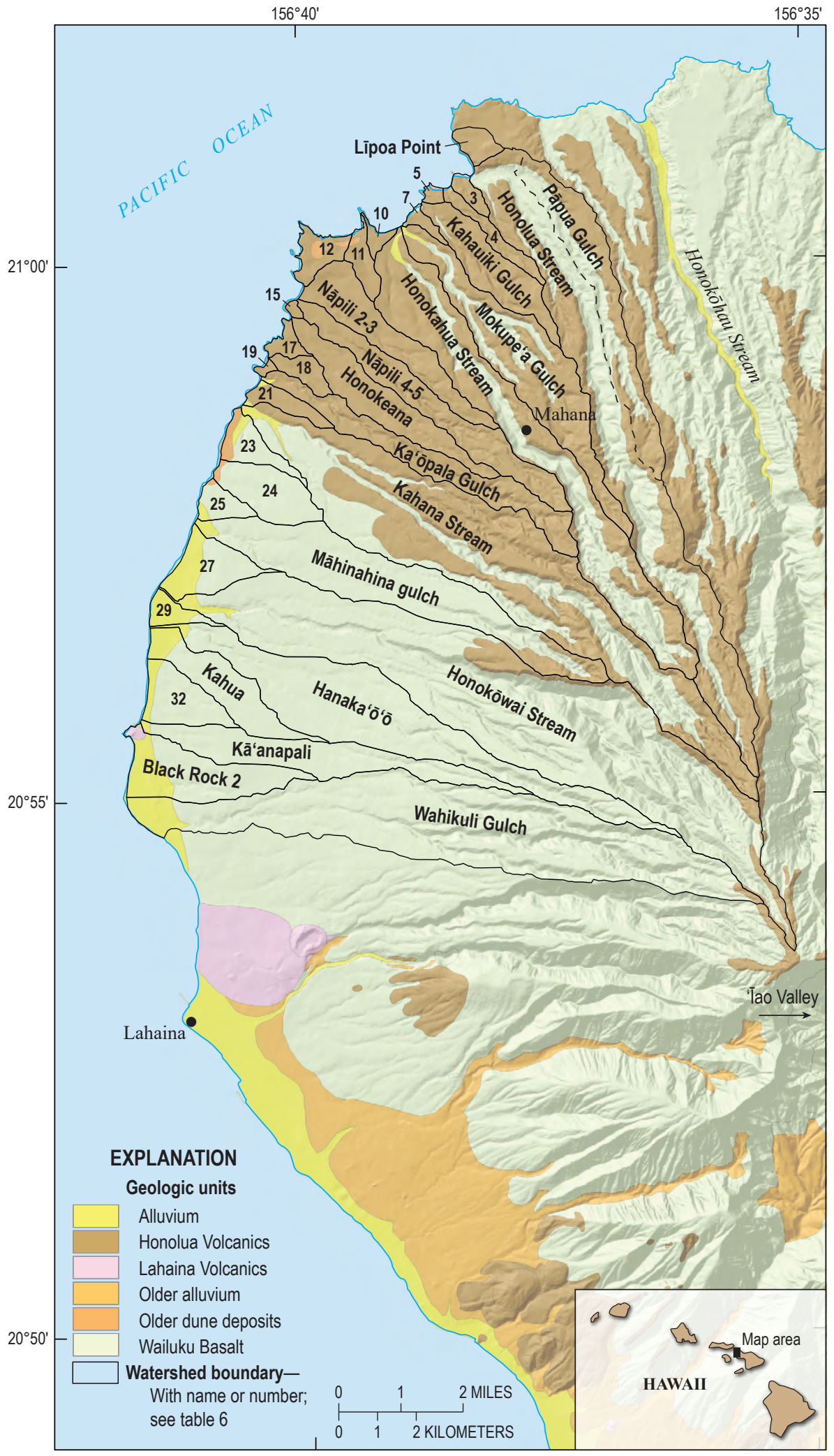

Figure 2. Map showing geology and major watersheds (unnamed watersheds are numbered) of West Maui draped over shaded-relief topography. Larger watersheds have steep headwaters characterized by rockfall and landslide processes and, towards the shore canyons, cut into low-relief surfaces composed of volcanic and alluvial deposits. A cap of bright-red-orange silts and fine sands over volcanic rock is a likely source of sedimentrich plumes polluting the nearshore after rainfalls. Geology from Sherrod and others (2007). of fine-sediment production for each process. We calculate sediment loads by multiplying each process area by its finesediment-production rate and summing these products for each watershed. We assume that this export is equivalent to supply, because we observed no short-term storage, a case we develop below. The resulting map explicitly shows potential mitigation targets, and the sediment budget allows the community to prioritize mitigation using potential impact.

There are substantial challenges to using this approach because good local measurements of erosion rate can take decades to develop. West Maui lacks short- and long-term estimates for hillslope sediment production from erosion pins 
or sediment traps (for example, Gellis and others, 1999, 2012), cosmogenic radionuclides (for example, Granger and others, 1996; Ferrier and others, 2013), and fallout radionuclides like cesium-137 or lead-210 (for example, McMurtry and others, 1995; Hill and others, 1997; Russel and others, 2001; Walling and others, 2002). West Maui also lacks suspendedsediment monitoring programs to provide authoritative values of fine-sediment export by streams, which can be used to close sediment budgets and test assumptions (for example, Warrick and others, 2015). The geology is largely uniform, which precludes some of the geochemical tools that could be used to assign suspended sediment (for example, Belmont and others, 2011) to mappable units. Erosion rates and suspended-sediment data are also needed to test the validity of generalized sediment-yield models (for example, Universal Soil Loss Equation-based approaches), whose parameters have proven difficult to apply in Hawaii's natural settings (for example, El-Swaify and others, 1982).

In the following sections, we develop the case for overcoming some of these data shortcomings to provide the best available science to guide mitigation decisions that are happening now. We describe the methods we used to map the areal extent of different geomorphic processes, record the rainfall intensities that activate processes, and calculate sediment production rates. These methods include field traverses to identify or verify sediment sources, infiltration tests to estimate saturated hydraulic conductivity of soils, analyses of rains impacting these and other deposits, and surveys of historic valley deposits that are likely sources for bank erosion. We describe how we measure annual bank erosion rates using cross sections of erosion pins and cohesive strength-meter tests to estimate the relative resistance of bank materials to erosion. We combine these elements to create a sediment budget for West Maui watersheds that incorporates both hillslope and bank erosion, and we discuss what this budget means for mitigating coastal sediment plumes. The goal is to provide science that the community can use to prioritize mitigation that keeps Maui's nearshore waters blue.

\section{Geology and Geomorphology}

Stearns and Macdonald (1942) and more recently Sherrod and others (2007) reported on the geology of West Maui. West Maui (fig. 2) was built as a basaltic shield by flows of the Wailuku Basalt, erupted 2 to $1.3 \mathrm{Ma}$ (megaannum or million years before present [1950]). These lavas flowed from a central vent, now occupied by 'Īao Valley, with rift zones marked by dikes that trend northward and south-southeastward. Flows dip steeply to the east and less steeply to the west. Stearns and Macdonald (1942) interpreted this asymmetry as a boundary effect created by the presence of an island to the northwest (Moloka'i) and the absence of an island to the east. Wailuku Basalt flows range from $\sim 1$ to 100 feet (ft) thick; unweathered flows are gray to grayblue. Pāhoehoe flows are interbedded with 'a'ā flows and autobreccia layers. Some dikes are found at high angles to the original flow direction, appearing as lineaments that cut across valley slopes. Wailuku Basalt flows are capped by weathered saprolites, airfall, soil, and, locally, alluvial deposits. Airfall deposits are widespread, and they represent the most likely reservoir of fine sand- and silt-sized material for coastal sediment plumes. Soils developed on both airfall deposits and volcanic flows are dark red and reddish brown (Stearns and Macdonald, 1942).

The Honolua Volcanics are a postshield, 1.3- to 1.1-Ma series of trachyte and benmoreite volcanic flows overlying the Wailuku Basalt flows. Flows of the Honolua Volcanics contain greater amounts of silica, potassium, and sodium than the Wailuku magmas (see fig. 23 in Sherrod and others, 2007). Reported thicknesses of the Honolua Volcanics range from $\sim 30 \mathrm{ft}$ to more than $200 \mathrm{ft}$ (Stearns and Macdonald, 1942; Patterson, 1971). The Honolua Volcanics formed domes (sheet 7 in Sherrod and others, 2007) because these magmas were more viscous than those of the Wailuku Basalt flows. Other surficial features, such as flow margins and pressure ridges, also have higher relief than equivalent features in the less viscous Wailuku Basalt. Saprolites developed on the Honolua Volcanics are white and gray (Sherrod and others, 2007), and soils are light gray, brown gray, and white (Stearns and Macdonald, 1942). Long after this shield and postshield volcanism, four small eruptions occurred near Lahaina at $\sim 0.6 \mathrm{Ma}$ and $\sim 0.3 \mathrm{Ma}$. Eruptions of the Lahaina Volcanics created four cones of low-silica volcanics (basanites), two of which released flows.

Valleys radiating from West Maui's center dissected rocks of the Wailuku Basalts and the overlying Honolua Volcanics. Low-relief remnants of lava-flow surfaces remain as wedge-shaped uplands, bounded by steep-sided valleys. Stearns and Macdonald (1942) called these remnants "flowslope plains," or "flow slopes" for short; later workers (for example, Patterson, 1971) called them "planeze." The northern watersheds are cut into both Honolua Volcanics and the underlying Wailuku Basalt. Starting near Honokōwai Stream and extending southward to Lahaina, watersheds are cut only in the older shield lavas of the Wailuku Basalt (fig. 2).

Bright-red-orange silts and fine sands blanket remnant flow surfaces of West Maui (fig. $3 A$ ). This material likely originated as airfall and other fragmental material during volcanism. It represents a prominent source of fine-grained material now visibly appearing in coastal waters as suspended sediment. These well-sorted, fine sediments are locally overlain by bouldery alluvium $\sim 2-3$ meters (m) thick (fig. $3 B$ ) that is the remnant of alluvial fans deposited prior to incision of the flow-slope plains.

\section{Climate}

West Maui's subtropical location leads to two very different rainfall events: tradewind-driven orographic rains and cyclones, and thunderstorms associated with low-pressure troughs or closed lows. About 70 percent of the year (Kodama and Barnes, 1997), a west-directed tradewind carries moist air 

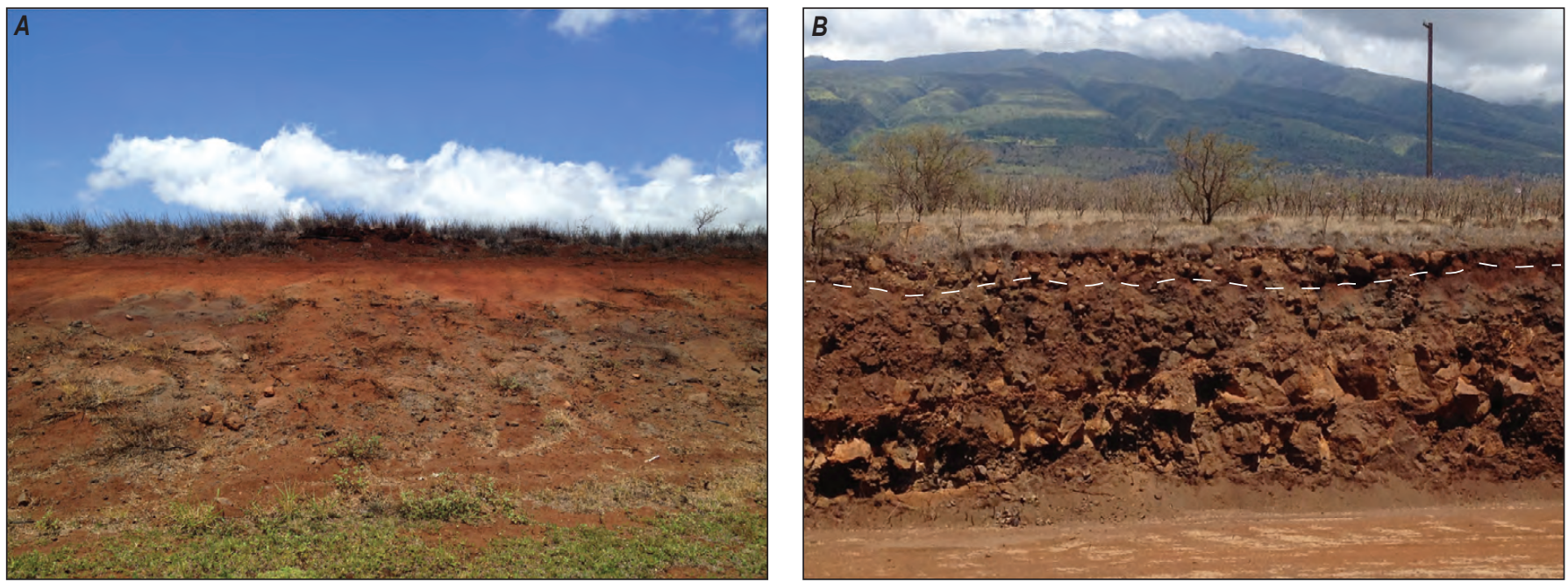

Figure 3. Photographs showing sediments overlying Honolua Volcanic flows. A, Fine-grained sand and silt deposits overlying flows of the Honolua Volcanics in the vicinity of Ka'anapali Coffee Farms, Kaanapali watershed. These red to red-orange granular deposits, as much as several meters thick, are found on low-relief surfaces. They represent volcanic airfall deposits or weathered saprolite, modified by pedogenesis. The most intense coastal plumes are red to red orange and likely come from deposits such as those shown here. B, Quarry wall exposure of flows of the Honolua Volcanics capped by bouldery alluvium above dashed white line. This alluvium likely represents an alluvial fan that once covered portions of the agricultural fields.

from the sea towards Hawaii's mountains, forcing air upwards. Adiabatic cooling results in a steady, low-intensity rainfall that starts on the east side of West Maui and extends over the crest and into the former agricultural fields of West Maui. The pattern of a wet windward side and a dry leeward side is one of the most obvious and remarked-upon climate gradients in the world. It separates dry land from rain forest, influencing how Hawaii's rocks weather and the geomorphology that transports sediments. Tradewind rains are not known to be intense enough to trigger either flash floods or landslides (for example, Kodama and Barnes, 1997), but their long duration provides much of Hawaii's water supply. Oki (2004) showed that, over the 20th century, Hawaii's water supply declined as tradewind-driven rainfalls decreased either in duration or intensity (Chu and Chen, 2005). Episodic cyclones and thunderstorms, however, do bring more intense rainfall to both wet and dry sides of the Hawaiian Islands. Cyclones may start in the subtropics as closed low-pressure systems (called "kona lows") or in the mid-latitudes as cut-off lows or the consequences of upper-level troughs. The cyclones generated by all three synoptic patterns and thunderstorms associated with upper-level troughs have the ability to bring intense rainfalls that exceed 10 millimeters per hour $(\mathrm{mm} / \mathrm{hr})$. Whether they do or not seems to depend on the mesoscale atmospheric conditions over each island when they arrive (for example, Kodama and Barnes, 1997).

\section{Geomorphic Processes in West Maui Watersheds}

Closed-canopy forests cover the headwaters of West Maui watersheds (fig. 4A). Soils and saprolites throughout these landscapes are bound by dense root networks. Root activity, burrowing animals, tree throw (fig. $4 B$ ), and other episodic activity move soil incrementally downslope at rates that are proportional to local slope (see, for example, Gilbert, 1909; Roering and others, 1999). This slow, episodic downslope movement is called soil creep. Where soil-mantled slopes abut the channels, pockets of fine-grained, dark soil can be entrained by stream flows. These areas are locally disturbed by pigs rooting up the soil with their snouts and hooves (fig. 4C). More commonly, soil creep fills in local depressions on old flow slopes, far away from valley margins. The margins of large valleys themselves are so steep that soil is patchy or absent (fig. 4D). Where slopes begin to exceed friction angles equivalent to $\sim 0.65$ (herein all slopes are reported in radians), soils thin to patchy exposures. At slopes greater than $0.70-0.85$, soil cover over rock is uncommon. Exposed bedrock fails episodically as rockfalls, some of which mobilize into debris flows. These flows likely cut shallow valleys fluted into the main-valley sidewall (fig. $4 D$ ). This terrain produces coarse particles (gravel to boulders) from rockfall, landslides, and other mass-wasting processes. Boulders and other coarse products of rockfalls (fig. $4 E$ ) and small debris flows accumulate as talus aprons (fig. $4 F$ ) or cones at valley-floor margins.

At elevations below closed-canopy forests, shrublands and grasslands cover the flow slopes. In middle and lower watershed areas, these low-relief surfaces were modified to serve as agricultural fields for the production of sugar cane and pineapple, starting in the 19th century. Large-scale agriculture ceased in the last decade. Some fields have been developed as golf courses (for example, in lower Honolua watershed) and others lie fallow (for example, lower Honokōwai watershed). 
A. Honokahua watershed

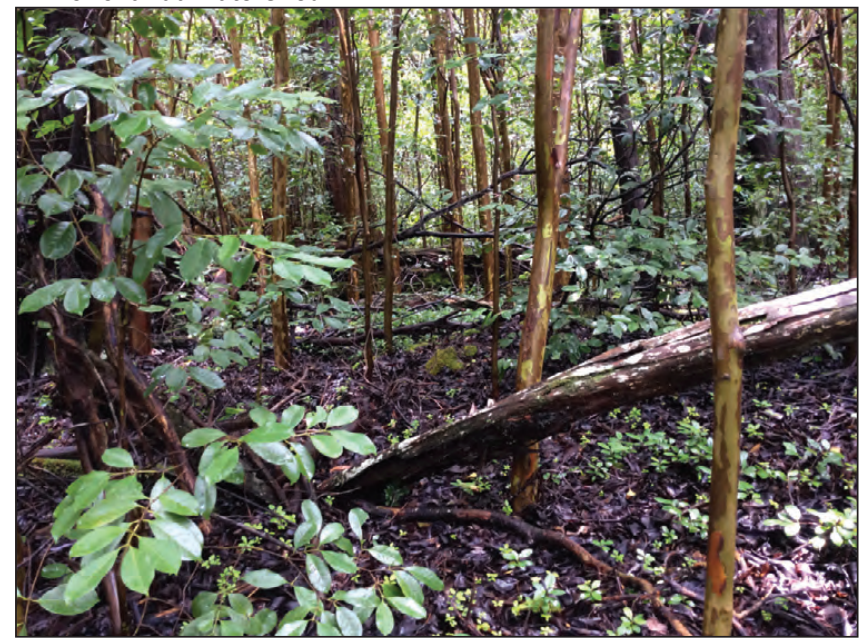

C. Honokōwai watershed

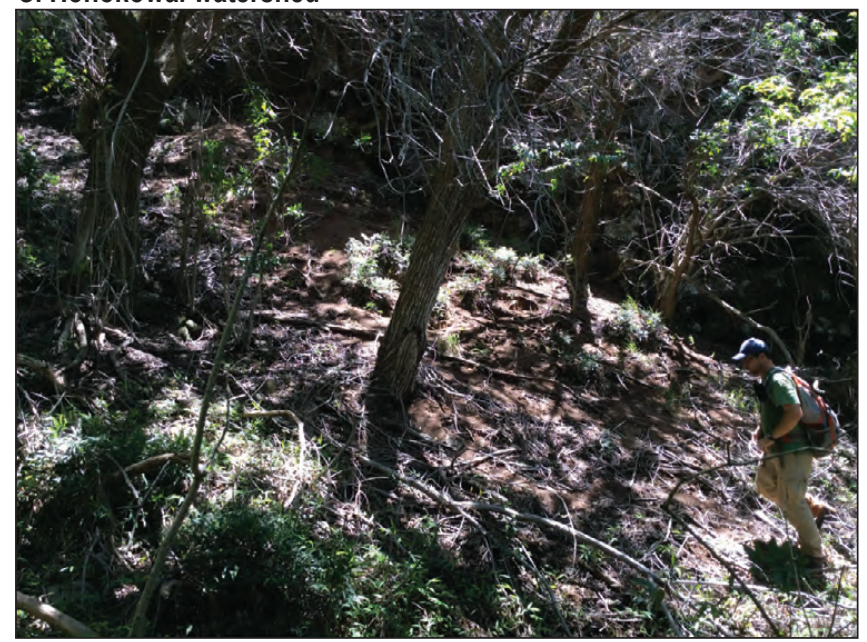

E. Honokōwai watershed

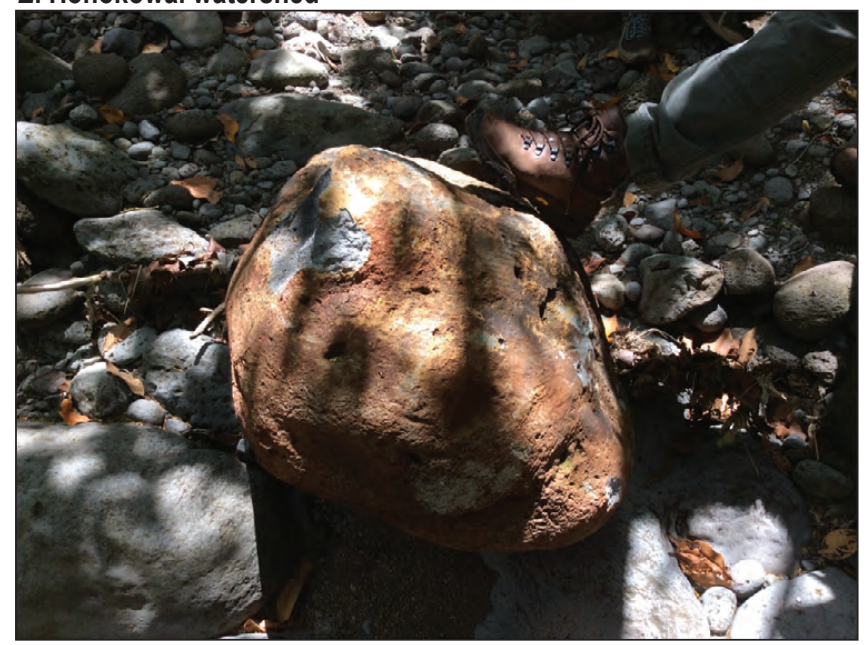

B. Honokahua watershed

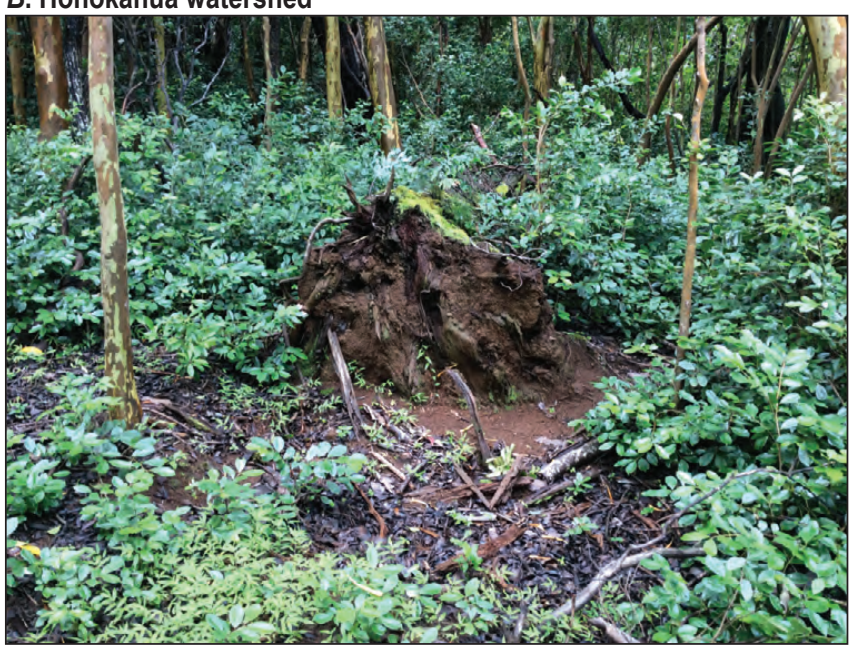

\section{Honokōwai watershed}

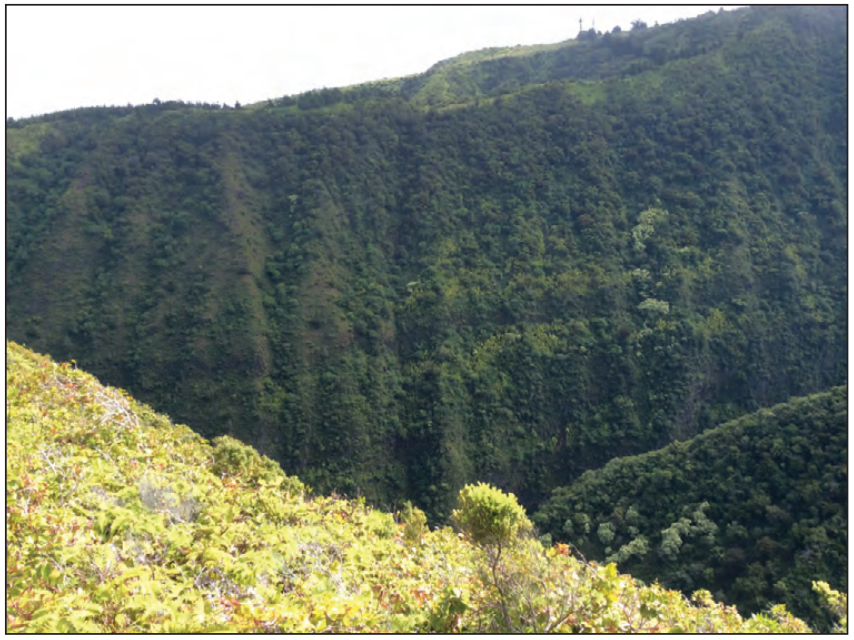

\section{F. Honokōwai watershed}

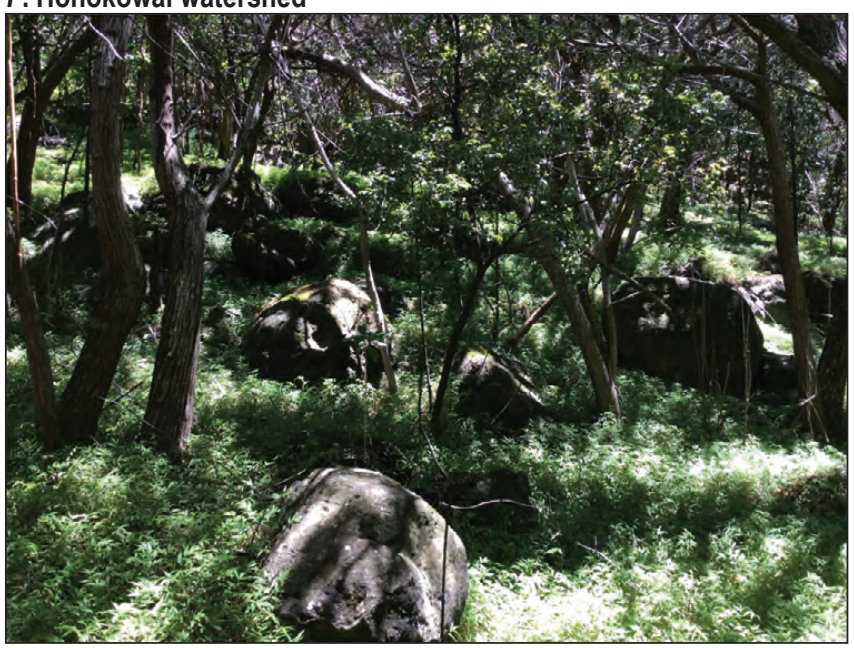

Figure 4. Photographs showing gravity-driven hillslope geomorphic processes of West Maui. $A$, Closed-canopy forests in headwaters, where sediment transport is characterized by slow, episodic soil creep. $B$, Example of soil creep from tree throw (episodic downslope soil movement from uprooted trees) in headwaters of Mokupe'a valley. C, Soil-mantled slope abutting stream, with feral pig activity moving dark, organic-rich soil into channel to right. Chris Brosius, West Maui Watershed Partnership Program Manager. D, Hillslopes characterized by rockfall processes, north of Honokōwai-upper rain gage. $E$, Weathered boulder showing impact marks from recent rockfall transport to Honokōwai Stream bed. $F$, Angular boulders deposited as talus by rockfall processes. 
The episodic movement of soil by creep occurs under these different land covers, at rates that are slow but not quantified.

Where human activity exposes soil or saprolite, rainfall rates influence erosion rate and transport. On slopes of exposed granular material, raindrop impacts send grains flying in all directions, with a net-downslope flux because those headed downslope travel farther than those moving upslope. This process of rainsplash leaves subtle pits in loose soil, particularly when the rainfall rates are too low to pond water. When rainfall rates exceed a soil's capacity to transmit water, ponded water may flow downslope as Horton overland flow (fig. $5 \mathrm{~A}$ ), entraining and transporting granular material. Where channelized, this flow leaves margins of loose vegetation fragments behind (grass, twigs, and leaves) and a channel washed clean of the loosest particles. Where subtle topography focuses this flow, rills (fig. $5 B$ ) and gullies form as water shear stresses entrain soil and saprolite. In developed land, drainage has been compartmentalized with local soil berms and waterbars. Some flows travel into these unconfined areas and deposit sand and coarser particles in small depressions (fig. 5C). A few flows feed into tributary streams, providing a source of sediment-charged water to mainstream valleys.

Ancient alluvial-fan deposits of gravel, cobbles, and boulders can be found on the flow slope. These deposits impede agricultural practice. Tool-marked boulders are now found in piles and as berms along the agricultural field margins. Piles of red-orange silty sand cascade over some field margins and down the sideslopes of the adjacent steep valleys as sidecast (figs. $5 D, E, F, 6$ ), the deposits formed by bulldozing material onto slopes.
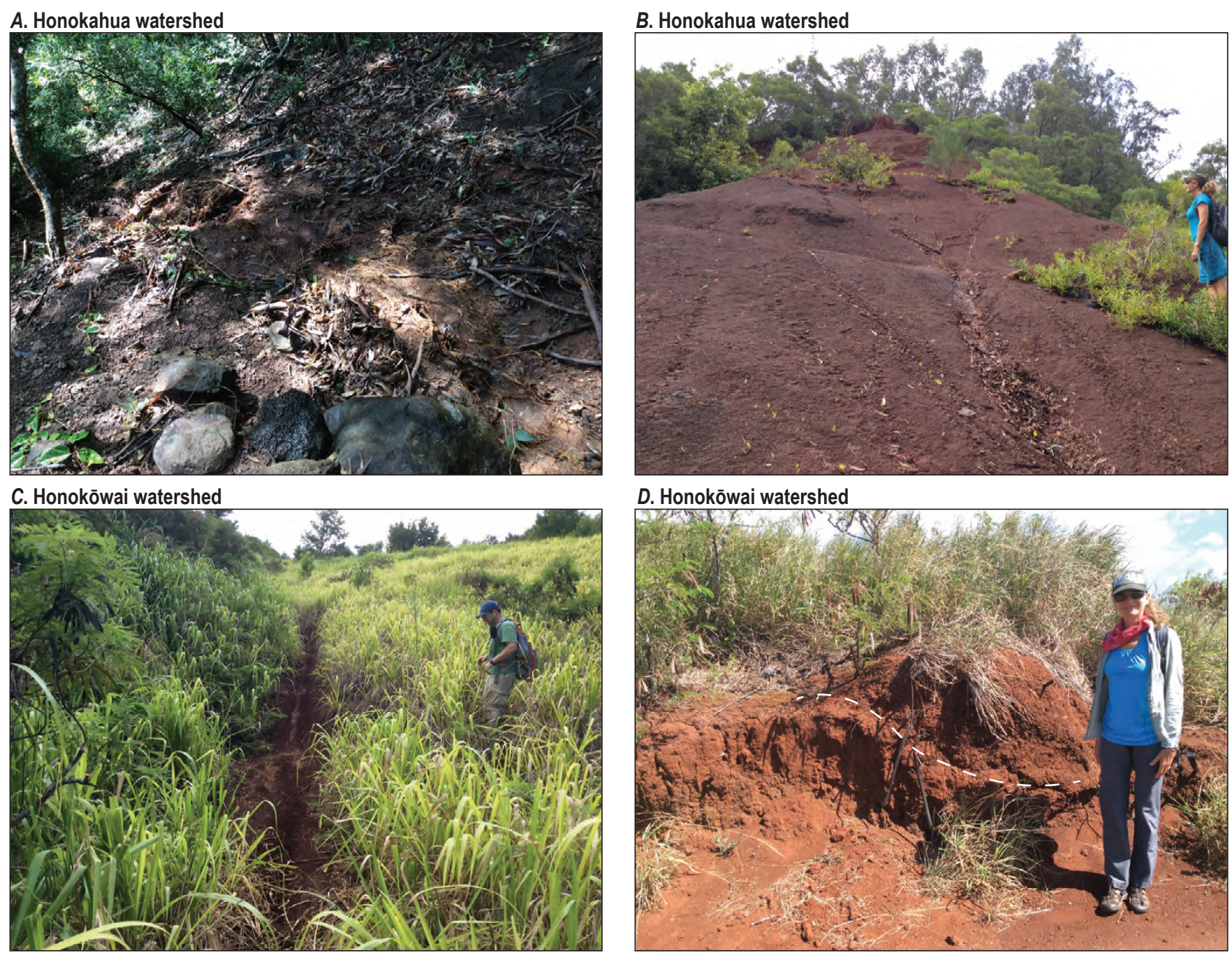

Figure 5. Photographs showing fluid-driven hillslope geomorphic processes in West Maui. $A$, Channelized Horton overland flow from rains on July 19-20, 2014. B, Horton overland flow focused into rills on exposed saprolite of Honolua Volcanics. Tova Callendar, West Maui Watershed Coordinator. C, Sediment deposited by Horton overland flow in water-bar area of former agricultural fields. Chris Brosius, West Maui Watershed Partnership Program Manager. D, Dashed line shows contact between fine sediments with plastic drip tape pushed over in-place soils with peds. Tova Callendar, West Maui Watershed Coordinator. 


\section{E. Honolua watershed}

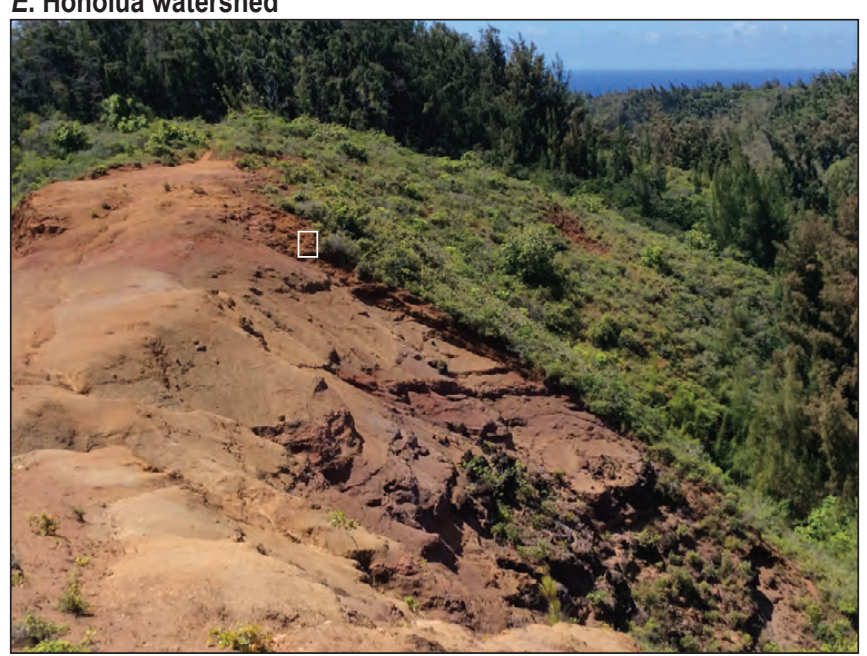

\section{F. Honolua watershed}

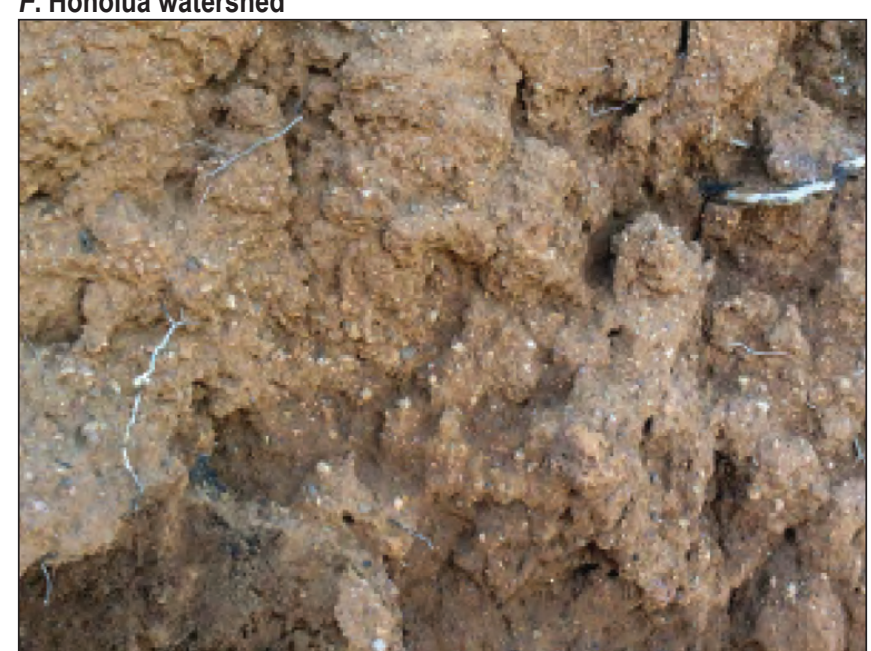

Figure 5.-Continued. Photographs showing fluid-driven hillslope geomorphic processes in West Maui. E, Ridge between Honolua Stream and Pāpua Gulch, showing sidecast layer removed by shallow landsliding and overland flow. Remnants of sidecast form an apron thinning downslope, delineated by dark, shadowed scarp running from center left of image to lower right. White box shows location of $F$. F, Enlargement of sidecast, illustrating nonsorted deposit with fragments of burned shrubs concentrated near its base.

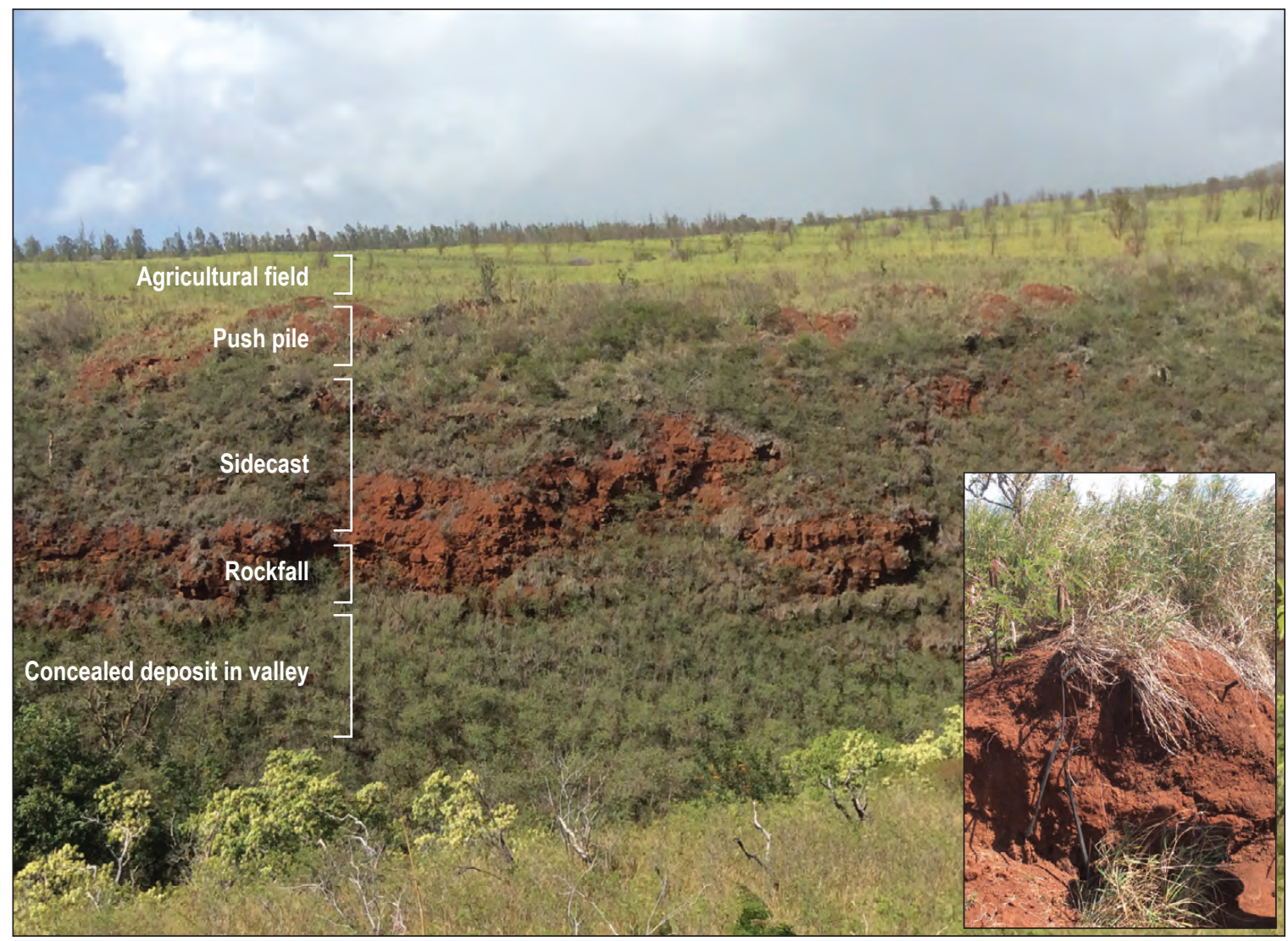

Figure 6. Historic deposits of fine sediment from agricultural practices near Wahikuli Gulch. Sugar-cane fieldworkers pushed piles of fine sediment with drip tape (see inset) to the valley margin and over onto the valley wall as sidecast. In the valley bottom, this sediment is present as small alluvial fans and as historic fill terraces. 
Steep (slope $>0.01$ ) valleys of West Maui are floored by pool-riffle, plane-bed, step-pool, and cascade bedforms composed of gravel, cobbles, and boulders (for example, fig. $7 A$ ). Pebbles and coarse sand are present in protected pockets and probably represent the mode of bedload. Silt or clay can be found as thin films in pools or stream margins or under large bed material but are not present in the active channel as large storage elements. There are no obvious pavements or armor (coarse surface layers underlain by finer particles). Upstream-facing tree trunks have scars up to several meters above the present bed surface, likely from debris flows or floods. Scar-damage heights are level with some terrace tops. Most of West Maui's streams are (or were) floored with gravel or coarser material.

Terrace deposits have sedimentary textures that record deposition by debris flow, stream-traction transport, or overland flow. From headwaters down to valley slopes of
0.03-0.05, some terraces have unsorted mixtures of sand and pebbles as a matrix for coarser particles (fig. $7 B$ ). Gravel, cobbles, and boulders are either clast supported or floating in the matrix. These deposits lack imbrication, and terrace surfaces commonly have aligned boulder berms. Silt and clay are likely present in the matrix but are not obvious in hand sample. These deposits record the passage of debris flows: mixtures of water, sediment, and vegetation whose movement is dominated by inertial forces. By contrast, other terrace deposits are clast-supported layers of imbricated cobbles with sand and imbricated pebbles as matrix (fig. 7C). These deposits record the grain-by-grain deposition of particles moved by fluid traction. In headwater areas, higher terraces tend to be more weathered (presumably older) than lower terraces. Downstream, the most weathered terraces are found near the margins of valley walls, and terraces closer to the active channel tend to be less weathered (presumably younger).
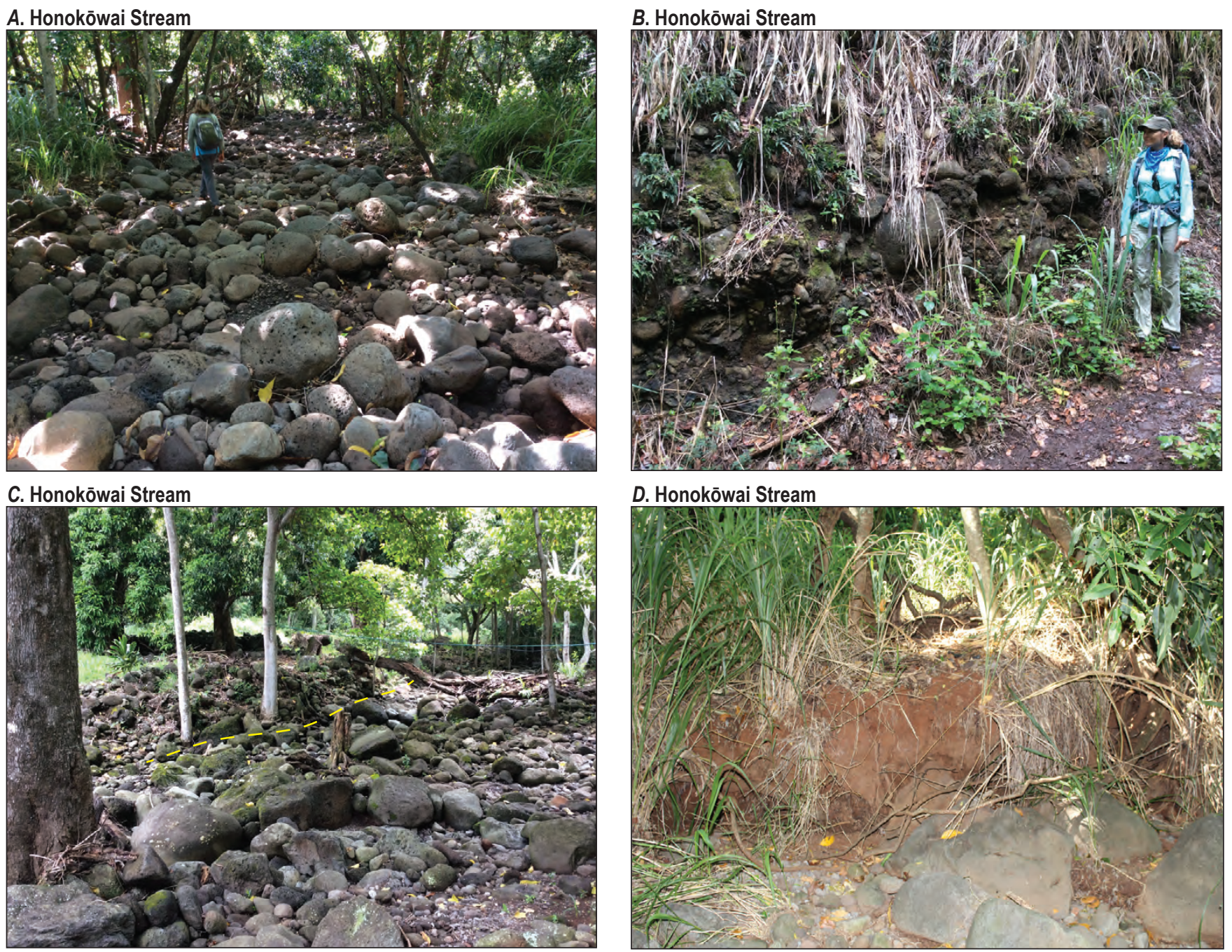

\section{Honokōwai Stream}

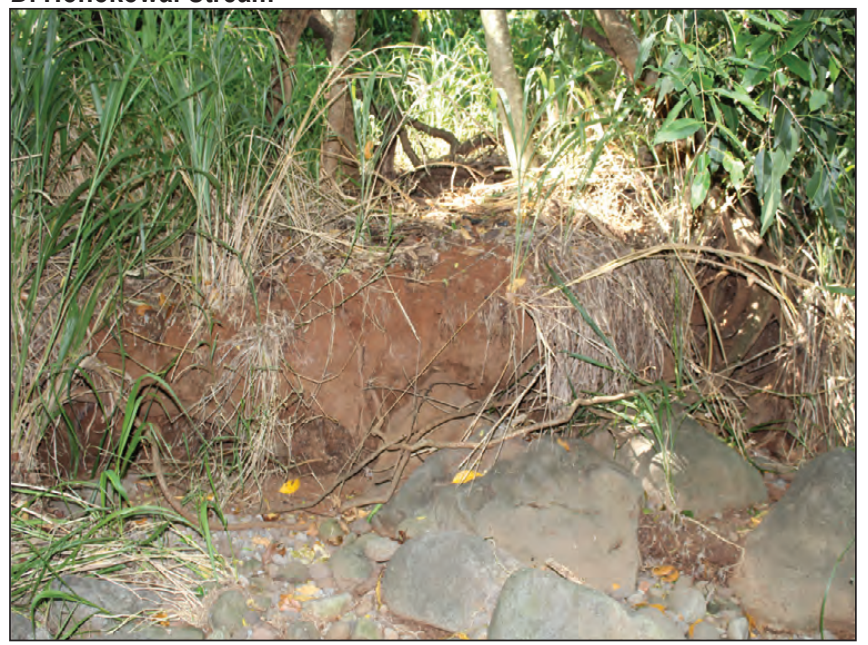

Figure 7. Photographs showing valley geomorphic processes in West Maui. A, Gravel-bedded stream typical of fluvial sediment transport down slopes of $0.01-0.08$ in valleys of West Maui. $B$, Unsorted terrace sediments without imbrication, likely deposited by debris flows, mobile at slopes greater than about 0.03-0.05. Tova Callendar, West Maui Watershed Coordinator. C, Sorted, imbricated deposits of a fluvial terrace above dashed yellow line. $D$, Fine sands, silts, and clays deposited as a historic fill terrace above Honokōwai sediment impoundment basin. 

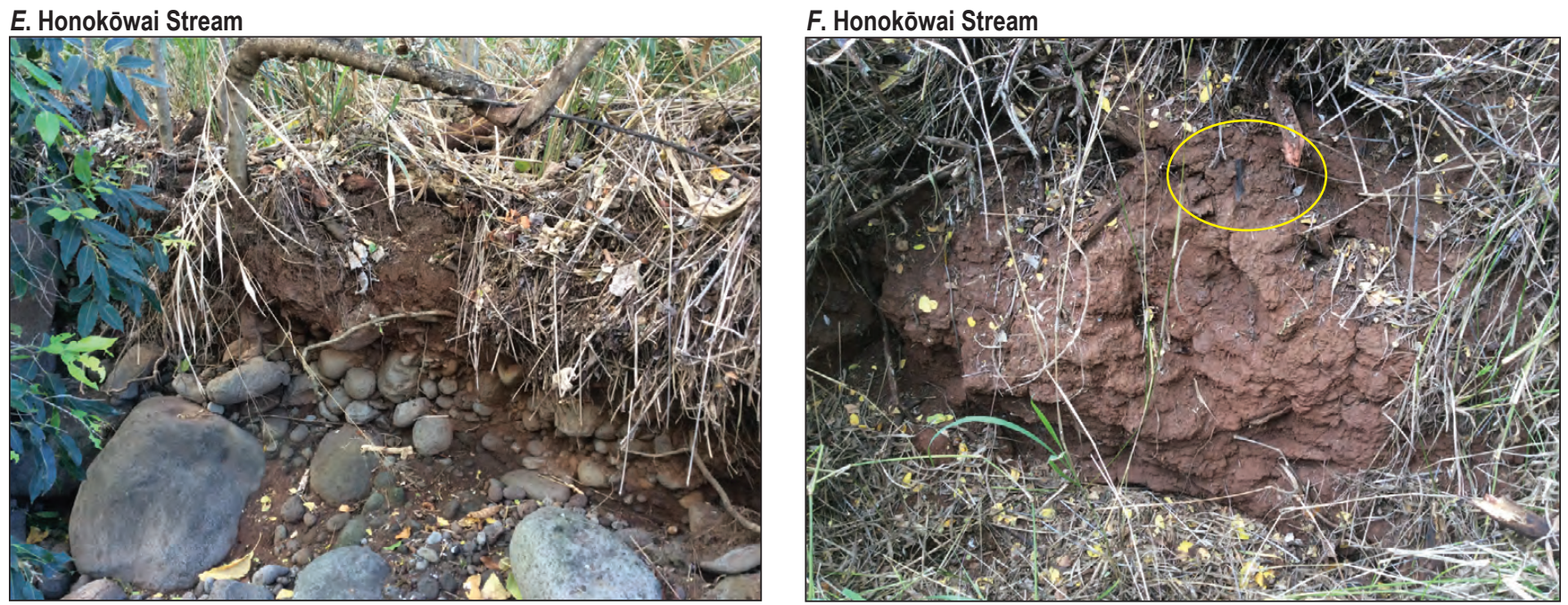

Figure 7.-Continued. Photographs showing valley geomorphic processes in West Maui. E, Fill terrace of fine sediments overlying gravel deposits that are characteristic of West Maui's gravel-bedded streams with slopes of $0.01-0.08$. $F$, Historic fill terrace, upstream of $D$, with embedded 1970s plastic drip tape (circled) from field-irrigation system.

Valleys adjacent to, or downstream of, agricultural fields have sandy silt draped over prehistoric, coarser-grained deposits (fig. 7D,E). These fine-grained deposits form historic fill terraces that are the stream banks along much of the lower channel. At some places, these fill terraces contain fragments of plastic irrigation drip tape (fig. $7 F$ ) and historical artifacts (fig. 8). The deposits are locally connected to aprons of similar material that slope up the sideslopes to join agricultural fields, perhaps as alluvial fans formed by overland flow depositing sidecast.

\section{Methods}

\section{Infiltration and Particle-Size Analysis}

To estimate rainfall rates that would cause overland flow on exposed soils, we performed 13 tension-disc infiltrometer measurements at 6 areas in former agricultural fields and unimproved (for example, dirt) roads (fig. 9), mostly on State of Hawaii-owned lands. These two land uses account for much of the exposed soil in West Maui that could provide fine sediment from hillslope runoff. At each measurement site (for example, fig. $10 A, B$ ), we chose a representative patch of undisturbed soil, cleared vegetation or large rock fragments from the surface, and used Decagon's tension-disc infiltrometer to infiltrate water. We used a suction head of $-1 \mathrm{~cm}$ to achieve a 15 - to 30-minute-long infiltration test. After each test, we excavated pits to look at subsurface water distribution. The patterns were elongated half spheres when sectioned, consistent with the absence of strong preferred flow paths in the well-mixed, finesand soils. We sampled soil from each site to characterize grainsize distribution, and we used the resulting U.S. Department of Agriculture (USDA) soil classification to estimate the van Genuchten parameters (van Genuchten, 1980) using Decagon's manual. From these tests, we calculated the saturated hydraulic conductivity $\left(\mathrm{K}_{\mathrm{sat}}\right)$ of the soils as an approximation of the rainfall rate above which soils would begin to pond water and erode by overland flow. The recurrence interval of storms that exceed this threshold-rainfall rate should provide an estimate of how often agricultural fields could release sediment to the nearshore.

We used a Beckman Coulter laser-diffraction particle analyzer to measure the grain-size distributions of soils. We sonicated samples but used no other pretreatment to disaggregate samples. Consequently, the grain-size distributions that we report represent the distribution of particle sizes relevant to permeability or sediment transport, not the clay mineralogy within the grains, which results from progressive weathering.

\section{Rainfall Analysis}

We searched the National Weather Service rainfall database for gages with 15-minute recording intervals near Honolua and Honokōwai watersheds (National Oceanic and Atmospheric Administration, 2014). We used these sub-hourly data to understand the historic record of rainfalls intense enough to cause erosive overland flow, their recurrence interval, and the intensity distribution of rainfalls for historic storms. The intent was to understand how often rainfalls could cause soil erosion and whether that frequency is changing. We used four gages (table 1) whose records span 7.3 to 27.6 years. Three of the gages are in the uplands (fig. 9), where trade-winddriven rainfalls occur (Field 46, Field 28, and Puu Kolii), and one gage is at the coast (Lahaina) where rainfall is dominated by low-pressure cyclonal events (for example, kona lows) or episodic frontal systems. Median rainfalls at the gages are $\sim 200$ millimeters per year ( $\mathrm{mm} / \mathrm{yr}$ ) at arid, coastal Lahaina and increase to the north from $\sim 400 \mathrm{~mm} / \mathrm{yr}$ (Puu Kolii) to $\sim 1,700$ $\mathrm{mm} / \mathrm{yr}$ (Field 46). 

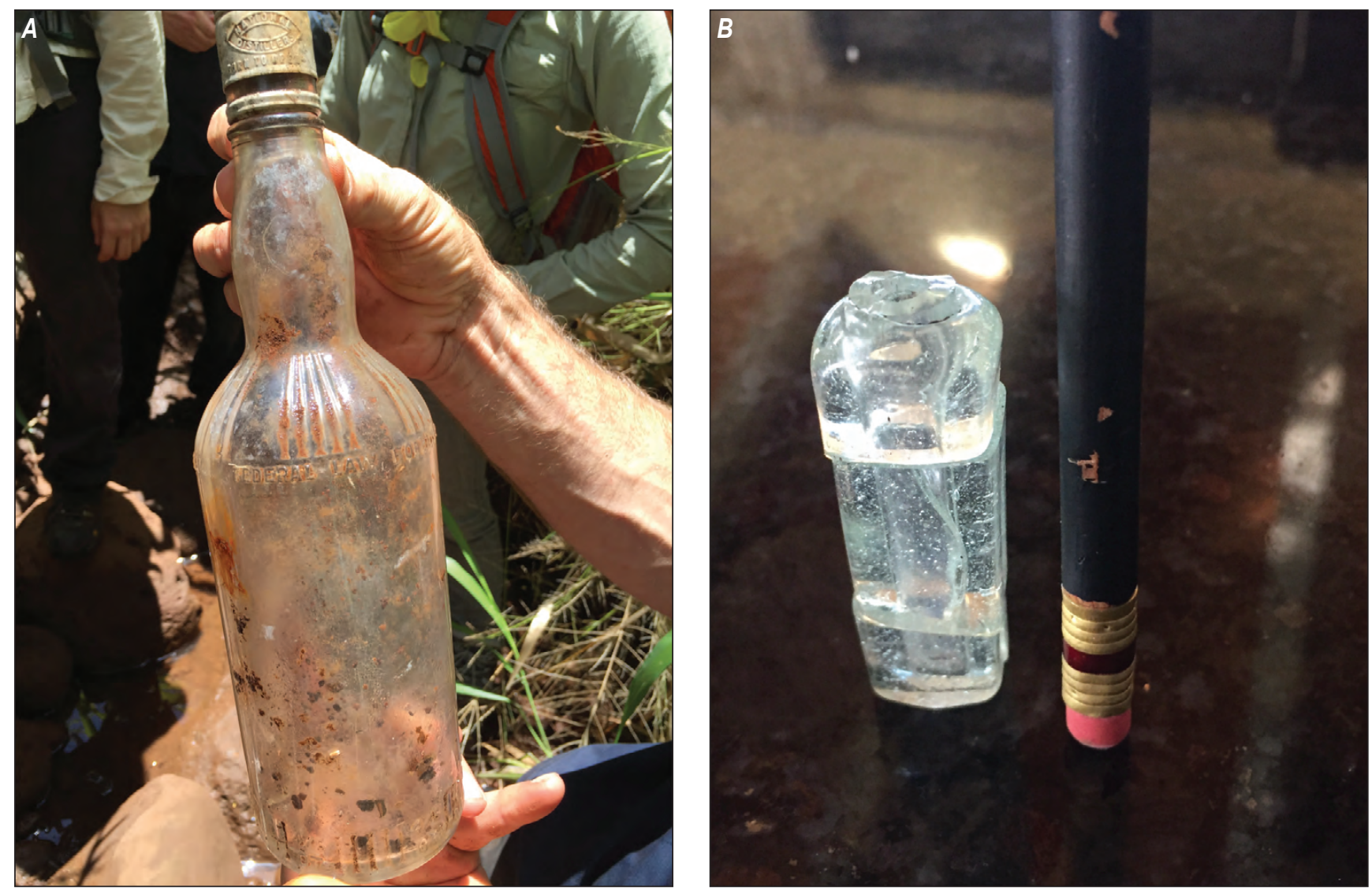

Figure 8. Historical artifacts embedded in fill terraces. A, Liquor bottle whose base stamp of Owens-lllinois Glass Co. indicates manufacture in 1954. B, Small glass vial from Honolua Stream fill terrace, likely a c.1900 opium container. These artifacts and the 1970s drip tape (fig. 7F) indicate that fill terraces were deposited throughout much of the 20th Century.

We removed a few spurious rainfall entries from the source data (for example, an isolated entry of 0.81 inches in 15 minutes). Each gage has missing data (table 1). Annual rainfall totals are summed over each water year, which starts on October 1 of each calendar year. The gages record rainfall at $2.54-\mathrm{mm}$ (0.1-inch) increments, so data are not continuous. We calculated rainfall intensity over 1 - and 2-hour periods using backward differencing (in other words, the intensity represents the total rain that fell over the past 1- to 2-hour period). We used the data to graph the number of hours each water year that 15 -minute rainfalls exceeded thresholds from 20 to $50 \mathrm{~mm} / \mathrm{hr}$ and to calculate the recurrence interval for 1- and 2-hour rainfall intensities from 20 to $50 \mathrm{~mm} / \mathrm{hr}$. We calculated recurrence interval $\tau_{\mathrm{r}}$ as follows:

$$
\tau_{\mathrm{r}}=\left(\mathrm{n}_{\text {present }}-\mathrm{n}_{\text {missing }}+1\right) / \text { ranking }
$$

where

$$
\begin{aligned}
& \mathrm{n}_{\text {present }} \quad \begin{array}{l}
\text { is the hours of rainfall present in the total } \\
\text { record, and }
\end{array} \\
& \mathrm{n}_{\text {missing }} \quad \text { is the hours of rainfall missing from the total } \\
& \text { record. }
\end{aligned}
$$

Events are ranked in order of decreasing intensity, so that the largest rainfall intensity has a rank of 1 , with rank increasing to $n_{\text {present }}$, the total number of rainfall hours in the record. In graphs, $\tau_{\mathrm{r}}$ is expressed in years.

To characterize the distribution of rainfall intensities in a given storm, we plotted the total number of hours exceeding a given intensity versus the intensity value. These plots are a convenient way to characterize both rain intensity and amount with two parameters. When the saturated hydraulic conductivity $\left(\mathrm{K}_{\mathrm{sat}}\right)$ of a surface is known, the plot can be used to estimate the hours of runoff and erosion that a storm could cause by reading the total hours exceeding a given conductivity.

Finally, we used the gages to reconstruct a history of heavy rainfall events in West Maui, defined by the number of hours of continuous rainfall at intensities greater than $20-50 \mathrm{~mm} / \mathrm{hr}$, a range that exceeds what we measured in the July 2014 plume-producing rainfalls. These records provide a sense of the frequency and magnitude of past storms capable of causing large sediment plumes in the nearshore. 


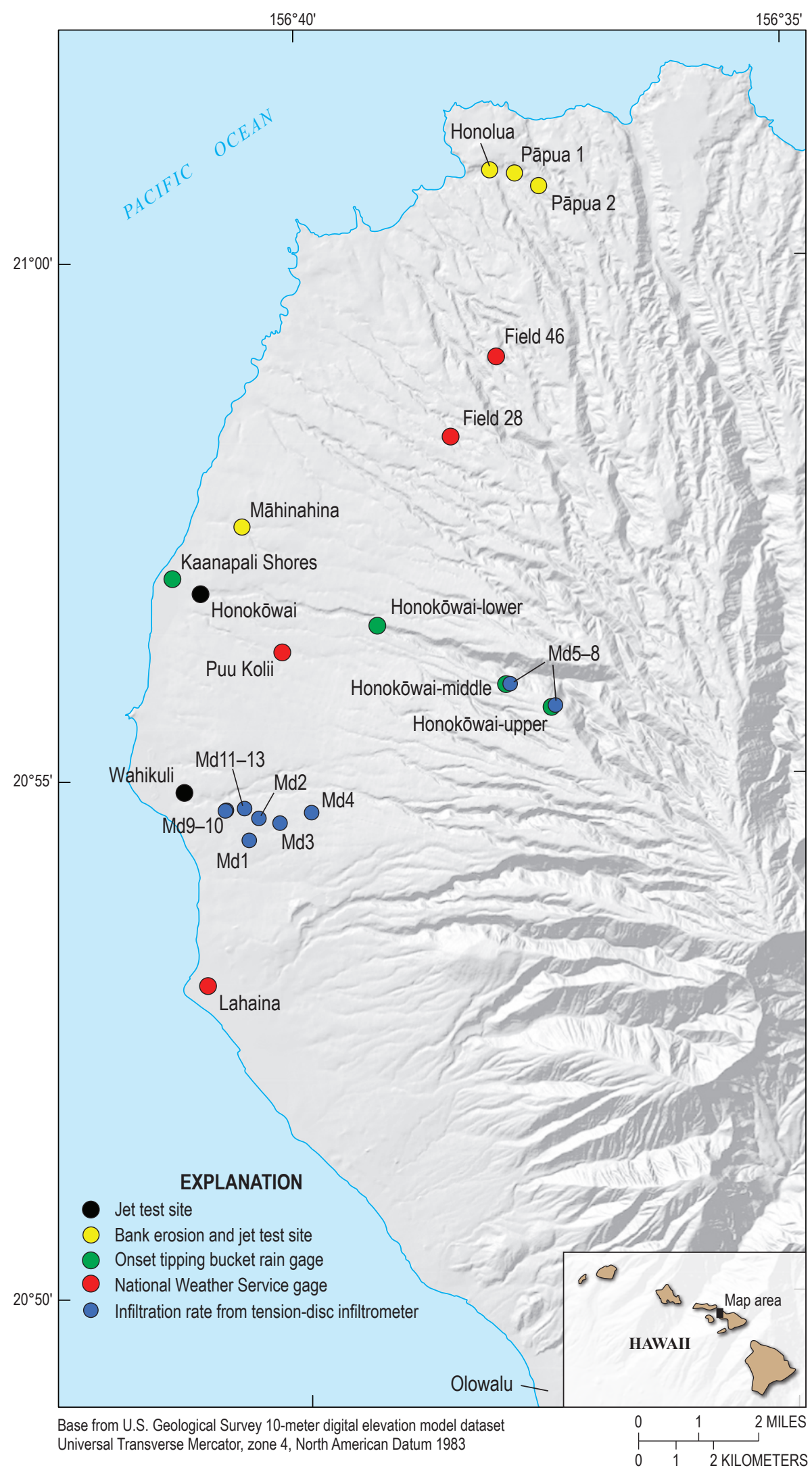

Figure 9. Map showing locations of field tests and instrumentation in West Maui. Onset RG3M tipping bucket rain gages were installed in spring 2014 by Tova Callender, West Maui Watershed Coordinator. Infiltration rates were determined from 13 infiltration tests conducted at 6 general sites with a tension-disc infiltrometer. Jet tests were conducted with a Partrec instrument, and bank erosion was monitored using erosion pins. National Weather Service gage data was obtained from National Oceanic and Atmospheric Administration (2014). 


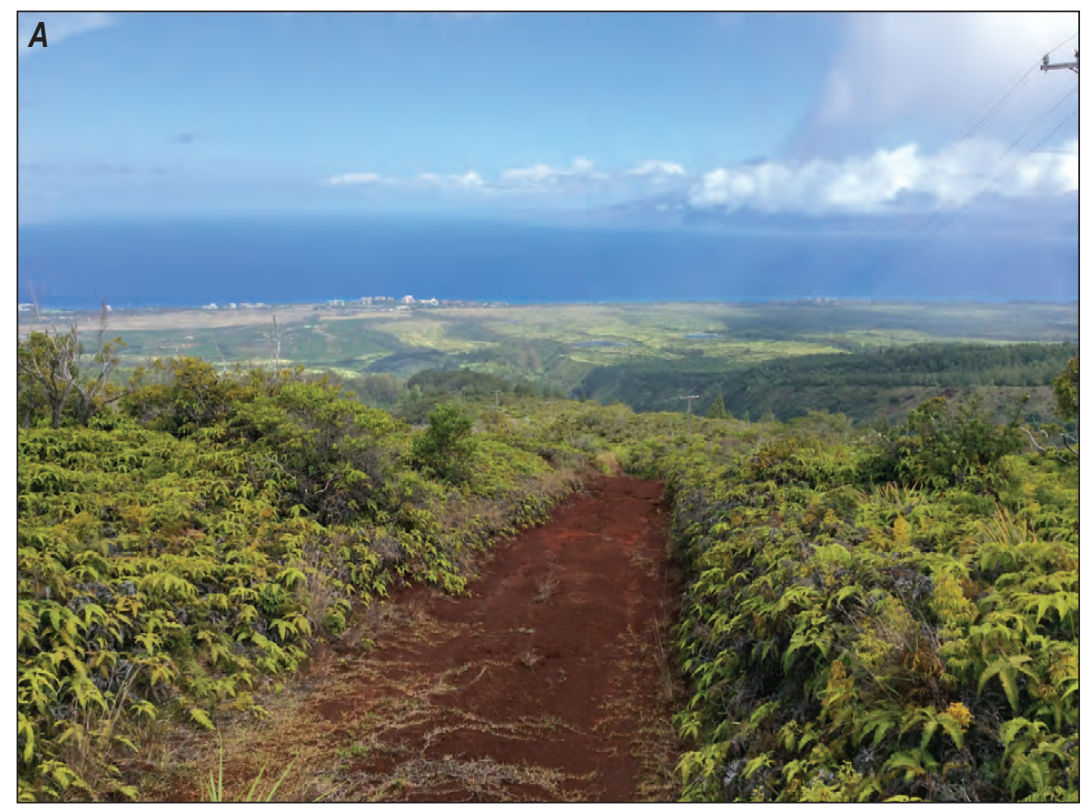

Figure 10. Photographs showing examples of infiltration-test sites at locations shown in figure 9 . $A$, Unimproved road south of Honokōwai Stream with evidence of minor runoff from July 19-20, 2014, rainfalls. We conducted hydraulic conductivity tests $\mathrm{md5}-8$ along this road. B, Trace evidence for road runoff on former agricultural fields south of Wahikuli Gulch but not for field runoff from July 19-20, 2014, rainfalls; site of $\mathrm{md} 9-10$ hydraulic conductivity tests.

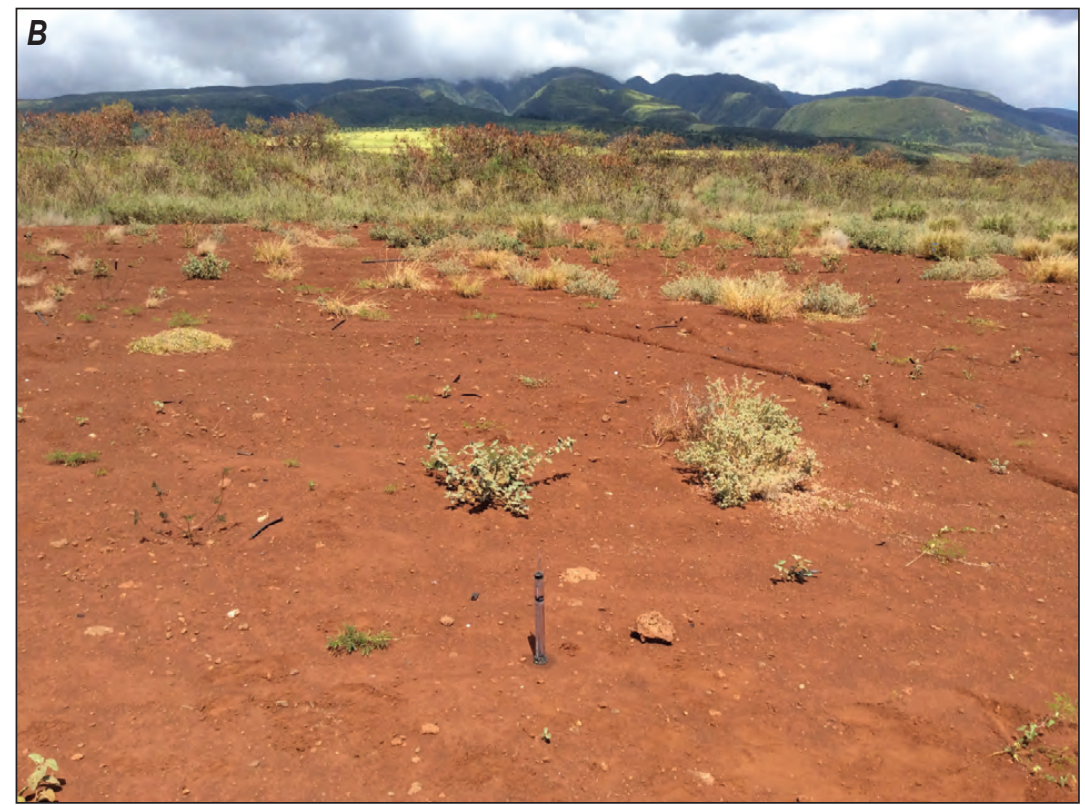

Table 1. Characteristics of selected National Weather Service rain gages, West Maui. See figure 9 for locations of rain gages.

[m, meters; $\mathrm{mm} / \mathrm{hr}$, millimeters per hour; $\mathrm{mm} / \mathrm{yr}$, millimeters per year]

\begin{tabular}{|c|c|c|c|c|c|c|c|c|c|c|}
\hline $\begin{array}{l}\text { Site of } \\
\text { rain gage }\end{array}$ & $\begin{array}{l}\text { Elevation } \\
\text { (m) }\end{array}$ & $\begin{array}{c}\text { Median } \\
\text { rain } \\
(\mathrm{mm} / \mathrm{yr})\end{array}$ & $\begin{array}{c}\text { Mean rain } \\
(\mathrm{mm} / \mathrm{yr})\end{array}$ & $\begin{array}{c}\text { Heavy } \\
\text { rain }^{1}\end{array}$ & $\begin{array}{l}\text { Very heavy } \\
\text { rain }^{2}\end{array}$ & $\begin{array}{c}\text { Sustained } \\
\text { heavy rain }\end{array}$ & Start date & End date & $\begin{array}{l}\text { Record } \\
\text { (years) }\end{array}$ & $\begin{array}{c}\text { Missing } \\
\text { data } \\
\text { (years) }\end{array}$ \\
\hline Lahaina & 5 & 239 & 275 & 3.0 & 0.7 & 0.8 & $11 / 1 / 1977$ & $10 / 25 / 2001$ & 24.0 & 0.036 \\
\hline Puu Kolii & 46 & 443 & 460 & 5.6 & 1.6 & 1.1 & $7 / 1 / 2002$ & $4 / 1 / 2013$ & 10.8 & 0.009 \\
\hline Field 28 & 107 & 1,055 & 1,017 & 7 & 2 & 1.4 & $1 / 5 / 2006$ & $4 / 19 / 2013$ & 7.3 & 0.021 \\
\hline
\end{tabular}

${ }^{1}$ Hours per year with rainfall intensity $>20 \mathrm{~mm} / \mathrm{hr}$.

${ }^{2}$ Hours per year with rainfall intensity $>40 \mathrm{~mm} / \mathrm{hr}$.

${ }^{3}$ Continuous hours per year with rainfall intensity $>20 \mathrm{~mm} / \mathrm{hr}$. 


\section{Geomorphic Mapping}

We mapped geomorphic processes in West Maui using 10-m USGS DEMs, 1951 orthoimagery, and 1/25/2014 1-m DigitalGlobe imagery. We derived slope maps of the $10-\mathrm{m}$ DEM using the maximum fall algorithm in ArcGIS, and we extracted a valley network by filling sinks and extracting drainage areas larger than 20,000 square meters $\left(\mathrm{m}^{2}\right)$ using ArcGIS. We find that including drainage-area values below this threshold leads to artifactual valley networks. The crude nature of the 10-m data, compared to 1-m lidar, means that many smaller features cannot be resolved and are absent from the map (for example, small landslide deposits, talus, terraces, and valley-margin details).

We divided the watershed area into 14 mappable units (see accompanying plate):

1. Landslide deposits and scarps (units Is, Iss)

2. Modified soil (unit ms)

3. Overland flow in agricultural fields (unit ofa)

4. Overland flow in exposed soils (unit ofh)

5. Rockfall (unit rk)

6. Sideslopes with mixed processes and sidecasts (unit ss)

7. Soil creep under canopy (unit ScC)

8. Soil creep in anthropogenic grasslands (unit scg)

9. Talus (unit tl)

10. Terrace (unit tr)

11. Developed areas (unit dv)

12. Valley deposits (unit vd)

13. Waterways (unit w)

To map rockfall (unit rk) areas, we used DigitalGlobe imagery and topographic slope to find steep (typically slope $>0.65$ ) valley walls with thin to absent soil and exposed bedrock. Small valleys sometimes indent or flute these rock walls (fig. 4D). Talus (unit t) occurs as aprons of boulders (for example, fig. $4 E$ ) below rockfall areas and can be identified in DigitalGlobe imagery by the presence of accumulated boulders deposited on slopes below rockfall areas (for example, fig. 4F). We mapped large landslides using the presence of scarps (unit Iss) and displaced masses (unit Is) evident on the 10-m topography (features tens to hundreds of meters in dimension). With one exception, they have the same canopy cover as adjacent areas, indicating that they are likely prehistoric. We mapped the extent of soil creep (for example, fig. $4 A, B, C$ ) using 2014 DigitalGlobe imagery to identify areas of canopied forest (excluding rockfall areas), grasslands, and long-fallow fields (unit scc).
We used 1-m DigitalGlobe imagery and 1951 orthoimagery (fig. 11) to map features that are consequences of human modifications to the landscape, including lawns and golf courses (unit scg), modified soils (unit ms), agricultural fields (unit ofa), sideslopes (unit ss), barren soils (unit ofh), developed areas (unit dv) and waterways (unit w). Modified soils (unit ms) may be machine-moved soil, including intermittent roads and structures, and piled boulders with or without vegetation. Modified soils and agricultural fields (unit ofa) can have machine-moved piles of soil, vegetation, and (or) boulders at the margins. These piles (figs. 5D, 6), where pushed off of the margins of the fields or roadways as sidecast, are represented by the sideslopes (unit ss). These deposits appear as high-albedo aprons in figure $11 B$, sourced from the boundaries of agricultural fields and cascading down steep sideslopes towards valley bottoms (fig. 6). They occupy areas that are elsewhere rockfall, talus, or soil creep. Exposed soil and rock (unit ofh) occur on some ridgelines in Honolua and other watersheds, likely following recent human disturbance. These exposures, locally, have headscarps and lateral scarps in soils, indicating that the processes maintaining fresh exposure are a combination of overland-flow erosion and shallow landsliding.

We used low-slope areas of the valley bottom to delineate the extent of valley deposits (unit vd) that characterize the debris-flow and fluvial-transport system (see, for example, fig. $7 A$ ). We identified prominent terraces (unit tr) by mapping the boundaries of steep-walled benches adjacent to valley deposits (fig. 7B,C). Mapped terraces are typically more than 3-m-high accumulations of fluvial or debris-flow deposits. Many smaller terraces, like historic fill terraces of figure $7 D-F$, are not resolved by $10-\mathrm{m}$ data and are included in the valley deposits unit (vd). To estimate their extent, we measured them in the field.

\section{Survey of Historic Fill Terraces}

Bank erosion of historic fill terraces is a visible source of fine-grained sediment. To calculate the sediment load from this process, we estimated the extent and rate of bank erosion. Surveying every eroding bank in the field area is not feasible. Instead, we surveyed the extent of historic fill terraces in four valleys that produce coastal sediment plumes, starting in the drier south with its ephemeral streams (for example, WahikuliHahakea Gulches), and moving to the wetter north with intermittent or perennial streams of $\mathrm{Ka}^{\text {‘ }}$ opala Gulch, Honolua Stream (lower part), and Pāpua Gulch. We walked the thalweg of each valley from shore to reaches above the influence of field agriculture. Teams of four to six people used Avenza Maps ${ }^{\circledR}$ software on iPads to create GPS tracks for right and left banks, where we observed fine-grained deposits. The resulting lines show the location of fine-grained fill terraces susceptible to bank erosion in the four example valleys. As we surveyed, we measured the thickness of exposed fine-grained fill-terrace sediments at opportunistic sites, and we visually 


\section{A. West Maui in 1951}
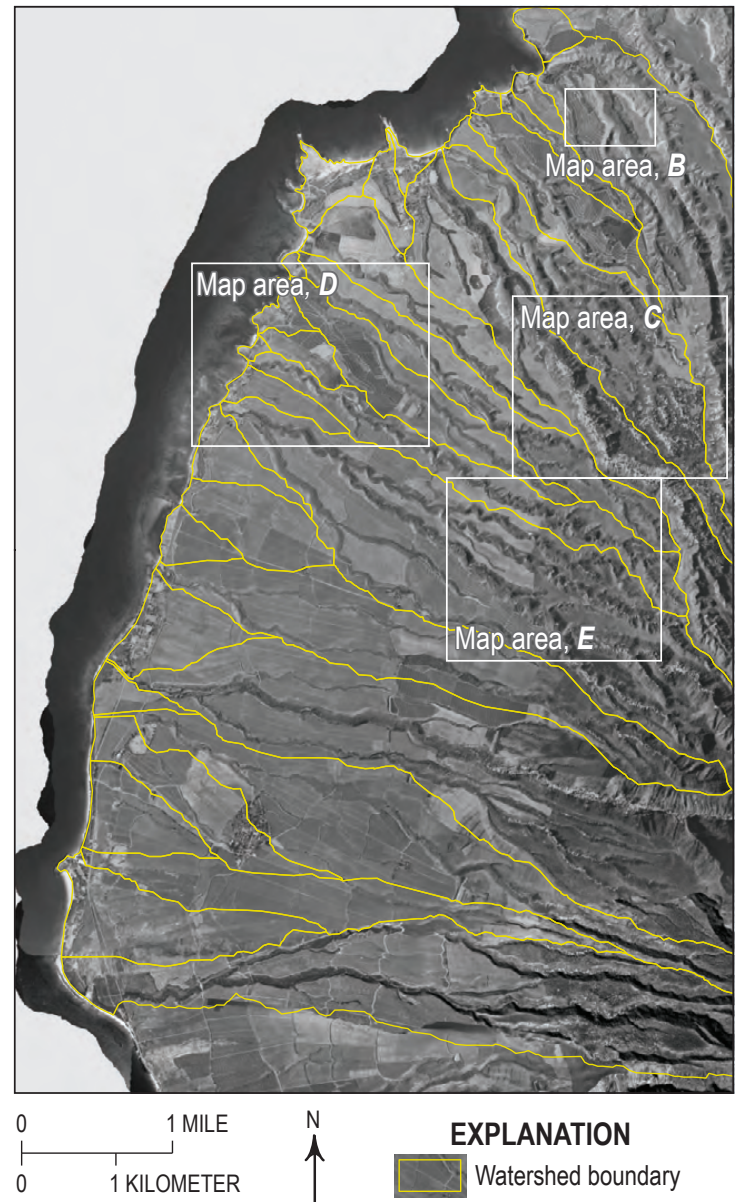

E. Field boundary (unit ofa) with soil creep (unit scc) in 1951

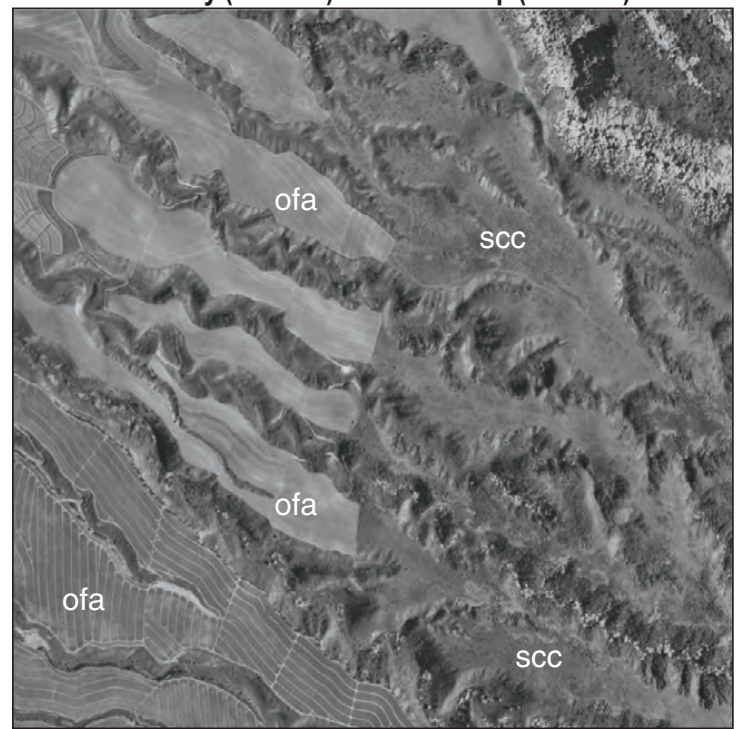

B. Sideslopes (unit ss) with sidecast from fields (unit ofa)

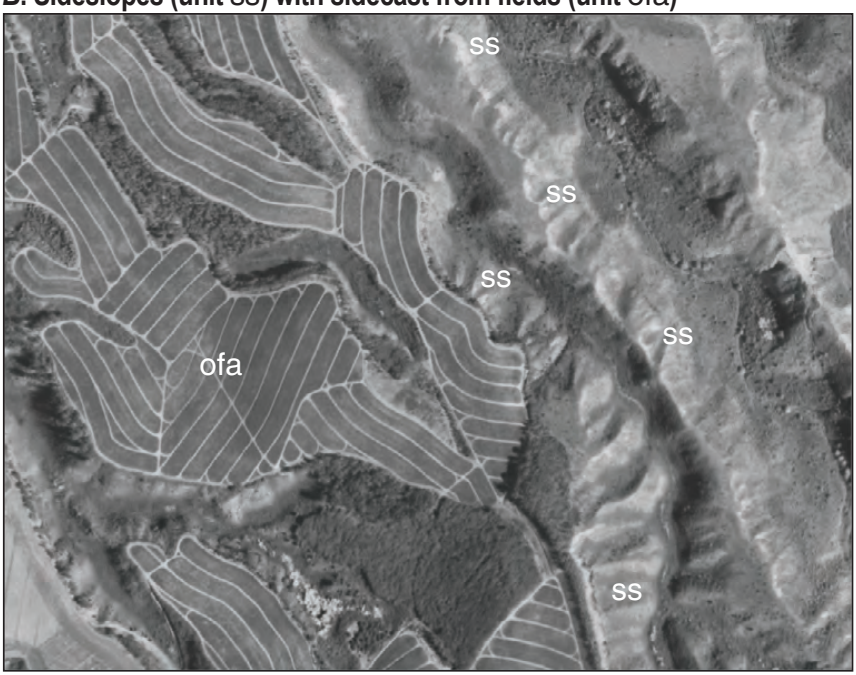

C. Agriculture (unit ofa) boundary with soil creep (unit scc)

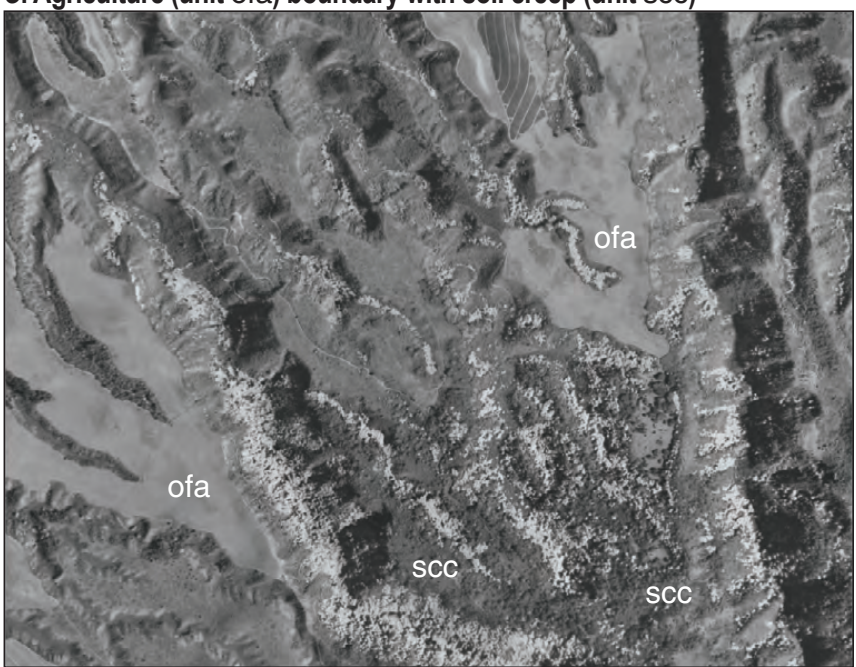

D. Unit ofa under pineapple (unit $\mathrm{p}$ ) and sugar cane (unit sc) production

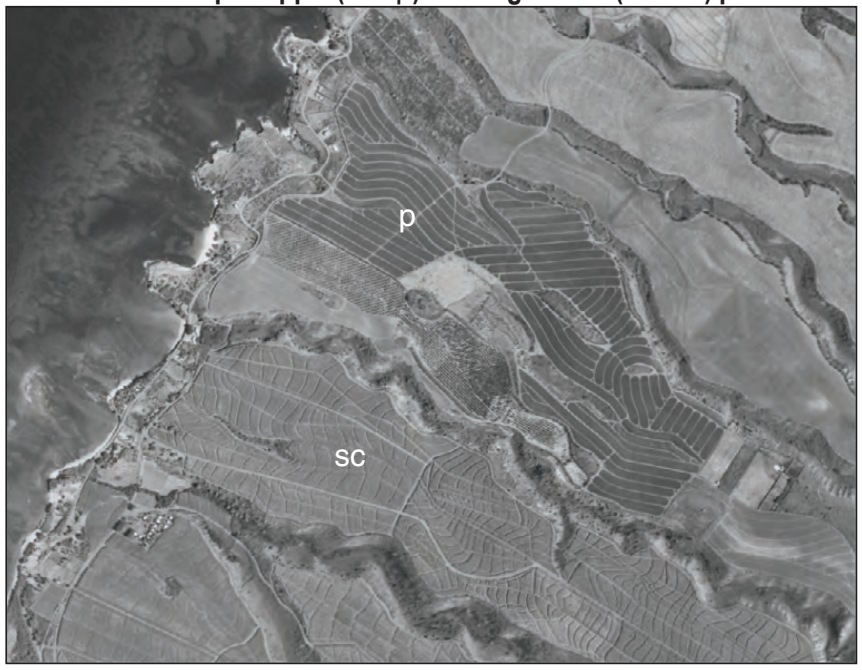

Figure 11. Orthophotographs of West Maui in 1951, illustrating pineapple and sugar-cane agricultural fields (unit ofa) and highalbedo sidecast cascading down the sideslopes (unit ss) due to former agricultural practices. $A$, Map showing location of maps $B-E$. $B$, Pineapple fields (unit ofa) with sidecast as high-albedo patches on valley walls. $C$, Fallow agricultural fields (unit ofa) bounded by canopied forest with soil creep (unit scc). D, Contrasting patterns of pineapple (unit p) and sugar-cane (unit sc) fields. $E$, Boundary of fallow agricultural fields with soil creep under forest canopy. Images $B-E$ show the source areas of fine sediments that were pushed into the valleys while shaping sugar-cane (unit sc) and pineapple (unit p) fields. 
estimated the fraction of the deposit coarser than sand. We did not map exposures less than $10 \mathrm{~m}$ in length.

We used the blue-line streams from the USGS National Hydrography Dataset (NHD; modified to match stream extents in imagery) to generalize our survey results to other watersheds. We also added a few prominent valleys that were not present on NHD, using valley networks we extracted from the threshold drainage area calculation in ArcGIS. We projected our surveyed right- and left-bank lines onto the NHD-modified streamline in each of the four surveyed valleys. This step, necessary to generalize to the rest of the watersheds, biases the bank-length estimates to low values because the NHD streamline is shorter and less sinuous than actual stream length. To calculate the fraction of bank length with fine material, we divided the total length of NHD streamlines in fine-grained valley deposits by the total NHD bank length (twice the total stream length to account for left and right banks). We averaged this fraction from all four sites to arrive at an estimate for the fraction of bank length in watersheds that is occupied by fine-grained valley deposits. We estimate the total length of eroding fine-grained banks in unsurveyed streams by multiplying each watershed's total NHD bank length by this fraction. The product of this total length of

\section{A. Pāpua Gulch, Pāpua 1 site}

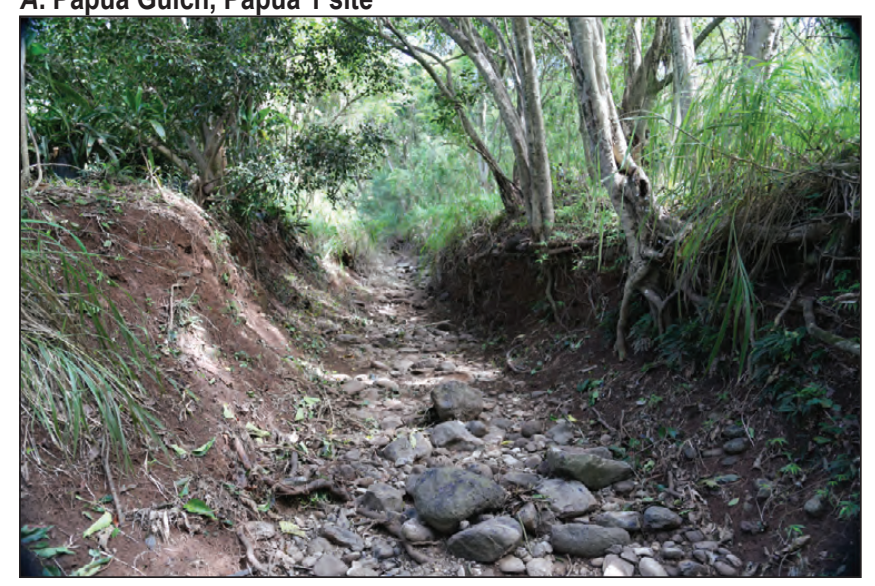

\section{Māhinahina gulch, Māhinahina site}

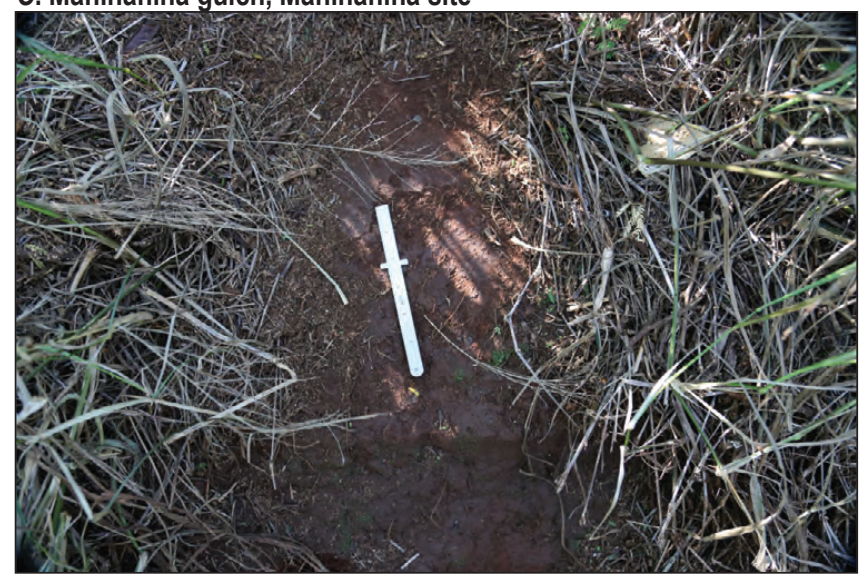

eroding banks and representative values for their thickness and fraction of fine-grained material can be multiplied by the bank-erosion rate to estimate suspended sediment flux from bank erosion.

\section{Measuring Hydraulic Geometry and Monitoring Representative Bank-Erosion Rates}

To estimate the annual release of suspended sediment from bank erosion, we selected four representative sites at which to install erosion pins (figs. 9, 12), 5-centimeter-long (5-cm-long) nails, to record bank-erosion rates. We selected sites in straight reaches with exposed fill-terrace deposits of silt and fine sand. At each site, we installed $\sim 20$ or more erosion pins to characterize lowering rates. We stretched a measuring tape taut between stakes on either bank and installed pins at even increments. We pushed, or lightly hammered in pins normal to the local surface until the rim of the pin was just below the surface. We characterize the range in bank-erosion rates using the end points of the Interquartile Range (IQR), with the lowest rate from the 25th percentile of lowering rates for ephemeral streams and the highest rate from the 75 th percentile of lowering rates for perennial streams.
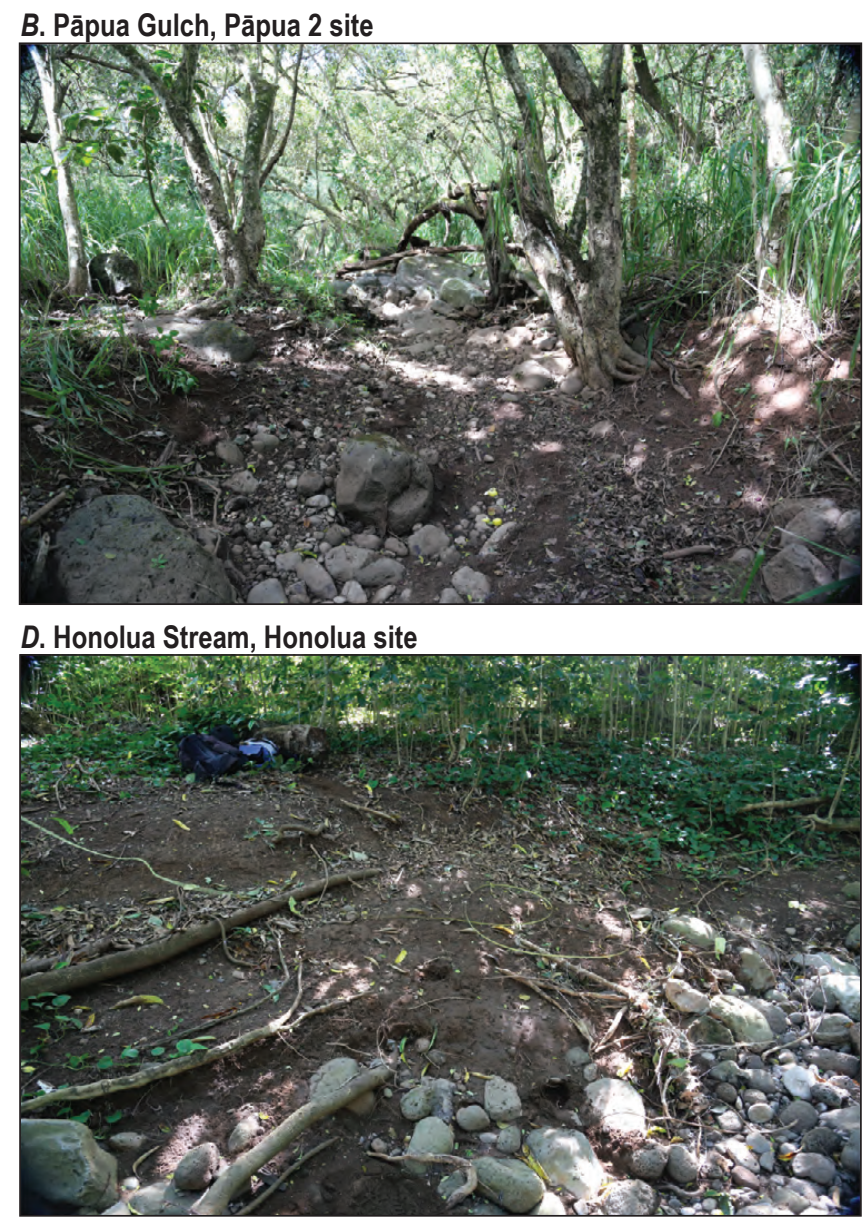

Figure 12. Bank erosion monitoring sites in West Maui. Each reach is relatively straight, bordered by a brown, fine-grained fill terrace. Gulches in Pāpua $(A, B)$ and Māhinahina $(C)$ are ephemeral (erosion pin for scale). D. Honolua Stream runs intermittently. See table 7 for cross-section data. 
With tape and hand level, we surveyed cross sections (fig. 13) and longitudinal profiles at each site to characterize the hydraulic forces driving erosion. We used this survey to estimate bankfull width, hydraulic radius, reach slope, and other channel characteristics. Recent high flows left debris and trim lines, which coincide with topographic evidence for banks, so we used the average depth and width of these flow lines to estimate bank width and hydraulic radius. We surveyed long profiles over lengths of five or more times bank width. We estimated bed grain-size distributions using Wolman's random walk method. To approximate steady, uniform flow stresses, we calculated average cross-sectional flow velocity using Manning's equation, with Manning's $n$ estimated as $0.1 \mathrm{~d}_{84}$. We also estimated the discharge recorded
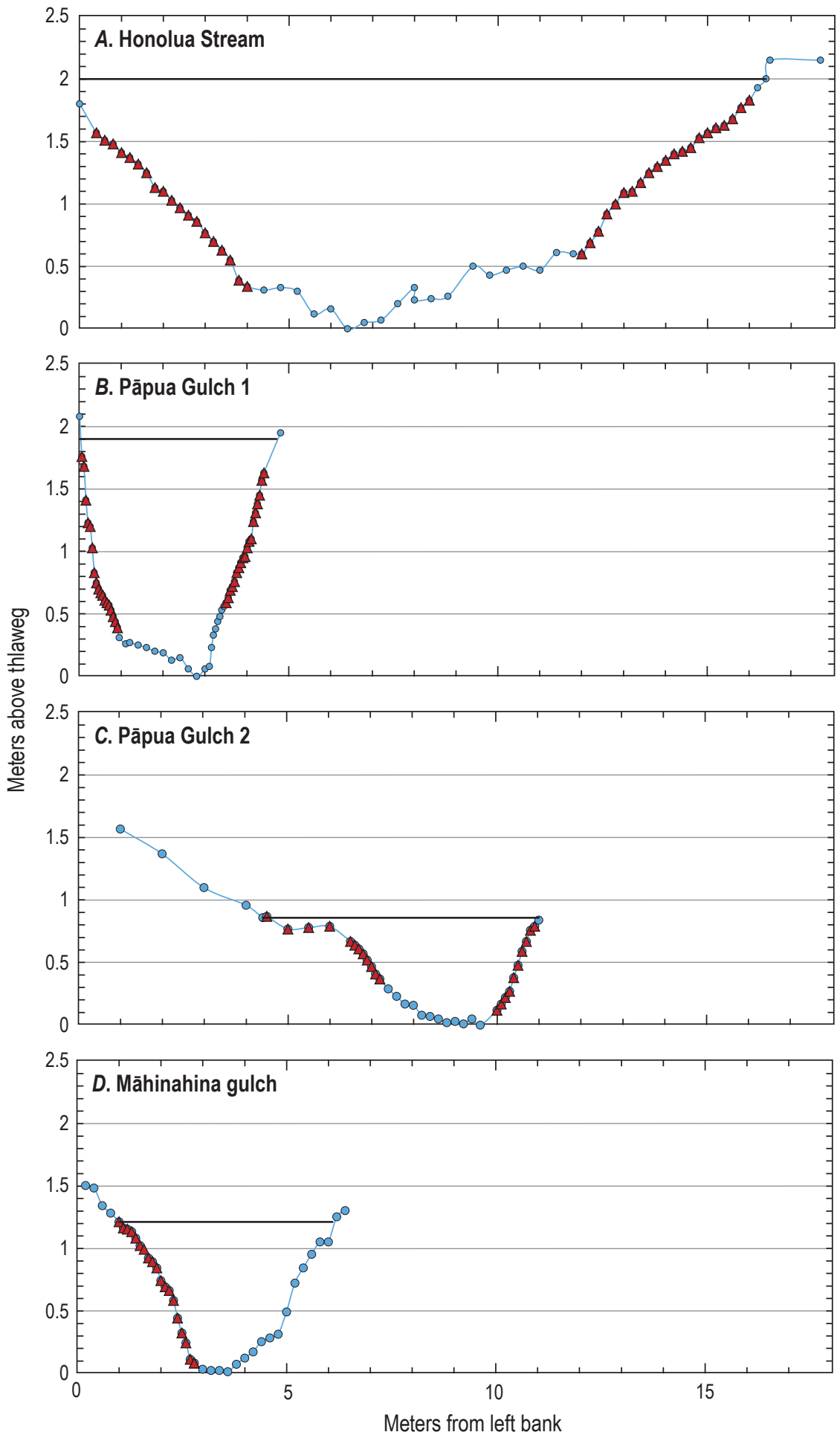

Figure 13. Cross sections of the stream channels (fig. 12) shown by blue line connecting blue dots; red triangles denote erosion pins installed to measure bank erosion. Solid black lines show field estimates of bankfull flow. Channel walls in these figures are composed of silts and fine sands from historic fill terraces. See table 7 for cross-section data. 
by recent trimlines (cross-sectional-averaged velocity multiplied by cross-sectional area) and the reach-average shear stress (hydraulic radius multiplied by reach slope, g, and water density). Flow velocity and discharge estimates have large unquantifiable errors because of the crude estimate for $\mathrm{n}$, whereas reach-averaged shear stress is not a particularly useful estimate of fluid forces from convective accelerations causing bank erosion. Such estimates do illustrate the relative increase in potential erosion with stream size, increasing from small streams like Māhinahina gulch to the largest section at Honolua Stream.

\section{Testing Resistance of Bank Material}

We used a Partrac Cohesive Strength Meter (CSM; fig. 14A) to estimate the cohesive strength of the fill-terrace sediment. The instrument is designed to simulate stresses that erode sediments in rivers and coastal estuaries. As described in Tolhurst and others (1999), the CSM uses compressed air to drive a water jet of known pressure against exposed sediment. An inverted, water-filled cup covers the impact site and houses an infrared (IR) emitter and sensor. These are positioned just above where the jet impinges on the sediment surface. As jet pressure is increased, eroded sediment in suspension reduces the transmission of IR light across the sample volume. The stresses that result from jet pressures that trigger rapid declines in IR transmission are arguably those required to overcome the cohesion of the sediment. Partrac provides a number of programmed tests that increment jet pressure from 0 to 60 pounds per square inch (PSI). Each test commences with an impulsive jet, followed by measurements of transmission over the following seconds. We used tests that ranged from 0-12 PSI for weak sediment (Mud 1) to 0-55 PSI for strong sediments (Mud 3). Each of these tests records transmission values at 1 hertz $(\mathrm{Hz})$ for 30 seconds after the jet impulse. Tolhurst and others (1999) use transmission values from the first few seconds of the jet impact, representing the material entrained by the jet stress before settling. We used the minimum value measured during the first three seconds. There is a debate about how to relate the fluid pressures recorded by the CSM to the localized stresses at the sample
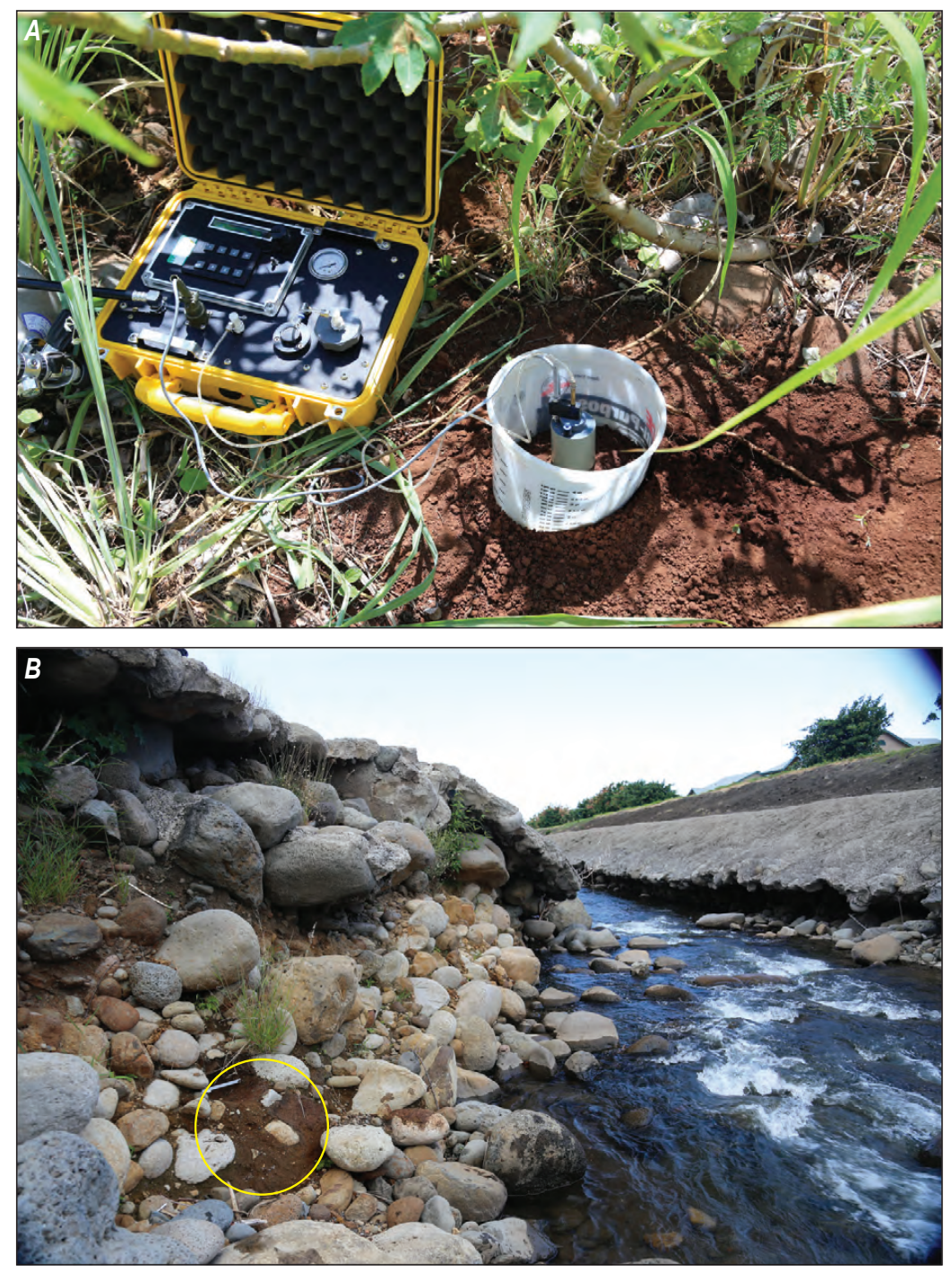

Figure 14. Illustration of Partrec's cohesive strength meter (CSM) deployed at $A$, Wahikuli Gulch fill terrace and $B$, 'Tao Stream, to characterize debris-flow-deposit matrix for a related project. $A$, The air tank along left edge pressurizes an internal water reservoir that the instrument pumps to a jet nozzle inside the gray cup in the bucket. During testing, both the gray test vessel and the surrounding bucket are filled with water to simulate submergence. These kinds of experiments provide estimates of how resistant fill-terrace material will be to erosion by streams. $B$, Test area shown by yellow circle. 
face. To estimate the stresses at the test face, some centimeters away from the jet initiation, we use a calibration from Vardy and others (2007) showing that the pressure at the test face is a multiple of 15.844 times the jet-nozzle-exit pressure. We interpret this value as an estimate of the Reynolds (or inertial) stresses that would erode material and, hence, an estimate of the material's cohesion.

We selected CSM sites at our four bank-erosion-pin monitoring sites and at additional sites along Honokōwai Stream and Wahikuli Gulch to extend geographical coverage (fig. 9). We also tested sandy fill-terrace material at 'Īao Stream (figs. 2, 14B) in the northeast side of West Maui to compare to our fine-grained examples. We chose horizontal or nearly horizontal surfaces and saturated them prior to the CSM test. Our intent by saturating the test surface was to simulate, as closely as possible, the material conditions preceding bank erosion. To accomplish this, we gently excavated a small moat around the test face and then emplaced a bottomless bucket (for example, fig. 14A). We filled the bucket with water, pouring it gently onto a thick paper towel that protected the test surface. When the soil was saturated, we removed the paper towel, emplaced the cup with the jet head on this surface, and initiated the jet test. Maintaining standing water in the bucket keeps the cup with the jet head underwater, a requirement for testing. Depending on the perceived strength of the material, we used a weak (Mud 1) or strong (Mud 3) pre-programmed test. Some sites required repeated tests to find an adequate pressure range. After testing, we sampled the sediment to estimate its particle-size distribution as a potential proxy value for bank resistance.

\section{Reconnaissance Sediment Budget}

To construct a watershed sediment budget, we summed all of the areas for each geomorphic process in a watershed and multiplied each total by a measured or hypothetical lowering rate (table 2) and a soil-bulk density to produce a sediment load in units of metric tons per year (metric tons/yr). In increasing order of magnitude, the uncertainties in this calculation are

- Uncertainty in bulk density estimate,

- Spatial variability in bulk density, and

- Spatial variability in point lowering rate.

We use 1,300 kilograms per cubic meter $\left(\mathrm{kg} / \mathrm{m}^{3}\right)$ to estimate soil and historic fill-terrace bulk density. This estimate comes from weighing a Shelby tube of fill-terrace material on Moloka'i, and likely overestimates soil bulk density, which tends to be closer to $900-1,200 \mathrm{~kg} / \mathrm{m}^{3}$ in Moloka' $i$ soils using the same method. Compressing granular media into a Shelby tube presents its own uncertainties, so these estimates should be viewed with some skepticism. Their likely effect on the sediment-load uncertainty (for example, 10-20 percent) must be small, however, compared to the uncertainties from the spatial variability of bulk density and lowering rate. We have no way of estimating these in the absence of measured sediment loads from stream gages or reservoirs. Therefore, except for bank-erosion budgets, we do not quantify the uncertainty beyond the notion that they may be an order of magnitude or more uncertain.

Table 2. Surface lowering rates used in reconnaissance sediment budget.

[Bold, estimate from measurement; italic, notional data; - , not applicable]

\begin{tabular}{llccc}
\hline $\begin{array}{c}\text { Map unit } \\
\text { label }\end{array}$ & Geomorphic process & $\begin{array}{c}\text { Annual storm } \\
\text { (mm/year) }\end{array}$ & $\begin{array}{c}\text { Hypothetical } \\
\text { decadal storm } \\
\text { (mm/year) }\end{array}$ & $\begin{array}{c}\text { Hypothetical } \\
\text { pre-human } \\
\text { (mm/year) }\end{array}$ \\
\hline rk & Rockfall & 0 & 0.03 & 0.03 \\
scc & Soil creep-canopy & 0 & 0 & 0.002 \\
scg & Soil creep-grass & 0 & 0 & 0.002 \\
ms & Modified soil & 0 & 0.1 & 0.002 \\
ofa & Overland flow ag. field & 0 & 0.1 & 0.002 \\
ofh & Overland flow hotspot & 0 & 1 & 0.002 \\
ss & Sideslopes & 0 & 0.1 & 0.002 \\
tl & Talus & 0 & 0 & 0 \\
tr & Terrace & 0 & 0 & 0 \\
Is, Iss & Landslides & 0 & 0 & 0.03 \\
vd & Valley deposits & 0 & 0 & 0 \\
u & Urbanized & 0 & 0 & 0.002 \\
w & Waterways & 0 & 0 & 0.002 \\
- & Bank erosion (wet side) & $\mathbf{1 4}$ & 14 & 0 \\
\hline & Bank erosion (dry side) & $\mathbf{5}$ & 5 & 0 \\
\hline
\end{tabular}


Table 2 lists yearly equivalent surface-lowering rates for three time scales:

- Annual storms that involve only bank erosion

- Decadal storms that erode agricultural fields

- Prehistoric lowering rates prior to human impacts

For annual storms that do not activate erosion in fields and other upland areas, we found that the majority of sediment that exits the watershed is from bank erosion, because there is no large storage of fine sediment in the channel. The effective lowering rate elsewhere is then zero. We calculated annual bank-erosion budgets by selecting the mainstem streams downstream of the boundary with historic agricultural fields. We multiplied the bank length of these mainstems from the NHD by the fraction of fine-grained banks, their median thickness, median fine-grained fraction, a bulk density estimate of $1,300 \mathrm{~kg} / \mathrm{m}^{3}$, and a median-bank-erosion rate from watersheds with perennial or intermittent streams (wet) or ephemeral streams (dry). The resulting load is an estimate of how much suspended sediment exits each watershed annually, with a crude-range estimate from propagating the IQR of bank-lowering rates (table 2).

For decadal storms, we assumed that soil creep from old flow slopes is largely unaffected by intense rainfalls and that urbanized areas and waterways also do not produce sediment. We assumed that rainfall intensities above the infiltration capacity of the agricultural fields would produce some runoff from agricultural fields and barren areas (units ofa and ofh), sideslopes (unit ss), and modified lands (unit $\mathrm{ms}$ ). These soils in former agricultural fields represent the largest reservoir of suspended-sized sediment in West Maui. We have no constraints on the lowering rates of these disturbed landscapes. For the purposes of exploring effects on the sediment budget, we hypothesize lowering rates of 0.1 $\mathrm{mm} / \mathrm{yr}$ (table 2), which approximates overland-flow-erosion rates found on rocky, barren soils on Moloka'i during intense rainfalls. This value is a major uncertainty in the decadal sediment budget.

Rockfall has the potential to deliver sediment directly to valley bottoms, but its lowering rates are unknown. We propose that the vertical component of the lowering rate of valley sidewalls should approach the long-term valleyincision rate. We calculated a valley-lowering rate midway up the basin, dividing valley relief by the age of the uppermost volcanic deposit (1.3-1.1 Ma; Sherrod and others, 2007). In the Honolua watershed, in the vicinity of Mahana (fig. 2), this calculation is $\sim 128 \mathrm{~m} /(1.3$ to $1.1 \mathrm{Ma})$, yielding a longterm bedrock valley lowering rate of $0.09-0.11 \mathrm{~mm} / \mathrm{yr}$. Talus deposits, the coarse products of rockfall, are clast-supported with porosities of about 30 percent. This volume represents the upper volume of fines that rockfall could produce. So, in areas of rockfall, the component of lowering that contributes suspended sediment is no more than one-third of the valley lowering rate of $\sim 0.1 \mathrm{~mm} / \mathrm{yr}$, or $\sim 0.03 \mathrm{~mm} / \mathrm{yr}$. We multiply the area of rockfall processes by this value to model the suspended-sediment load from rockfall (table 2). This value is almost certainly an overestimate, because it is unlikely that a third of rockfall by volume produces fine sediment. Whereas we assume that rockfall can deliver fine sediment directly to streams, both talus and prehistoric terrace deposits represent potential sinks of fine-sediment deposition. Consequently their contribution to the sediment budget is negligible.

Valley deposits are primarily gravel deposits of the active streams and terraces that are not imaged by coarse topographic data. Both could be storage sites for fine sediment originating from rockfall, soil creep, and overland flow. For instance, field observations indicate that fine sands, silts, and clays are in the matrix between gravel clasts of active streams. These fine sediments would be released when gravel moves. The resulting load is a very uncertain estimate of what a decadal storm would produce.

Estimating the suspended-sediment load to the nearshore before human impacts is particularly difficult in the absence of long-term estimates of soil creep. Low-relief surfaces (1-2 m) and advanced weathering profiles on flow slopes (Patterson, 1971) are inconsistent with more than several meters of lowering. Only a small fraction of soil-creep areas on flow slopes and elsewhere feed directly into streams. Most soil has to travel long distances by slow soil creep to reach valley walls. The lowering rate on flow slopes must be many orders of magnitude less than the long-term valley-boundary lowering rate of $\sim 0.1 \mathrm{~mm} / \mathrm{yr}$ to preserve the low-relief surfaces between the steep valleys. This suggests that over the 1.1-1.3 million years (m.y.) since eruption, rock-lowering rates of flow slopes were, very crudely, $1-2 \mathrm{~m} /(1.1-1.3 \mathrm{Ma})$, or $0.0007-0.002$ $\mathrm{mm} / \mathrm{yr}$. If lowering rates were much greater, these surfaces and their weathering carapaces would not have endured. Converting this rate to a soil-lowering rate (using rock/soil ratio of $2,900 / 1,300 \mathrm{~kg} / \mathrm{m}^{3}$ to account for the bulk density difference between rock and soil) gives $\sim 0.001-0.004 \mathrm{~mm} / \mathrm{yr}$. We use the midpoint of that range, $0.002 \mathrm{~mm} / \mathrm{yr}$, to approximate the annual prehistoric suspended-sediment flux for much of the watershed, except where landslide and rockfalls would cause lowering rates closer to $0.03 \mathrm{~mm} / \mathrm{yr}$ (table 2 ).

\section{Results}

\section{Observations on Plumes Following the Rainfalls of July 19-20, 2014}

A cyclonic-storm-generated rainfall on West Maui beginning 16:30 Hawaii Standard Time (herein all times of day are HST) on July 19, 2014, and ending 14:10 HST on July 20. Maximum intensities within the Honokōwai watershed occurred from about 06:00 to 08:00 on July 20. Tipping-bucket gages recorded rainfall totals of $67 \mathrm{~mm}$ at Honokōwai-upper, $80 \mathrm{~mm}$ at Honokōwai-lower, and $23 \mathrm{~mm}$ at Kaanapali Shores sites (figs. 9, 15A) over 14-15 hours. The gages recorded rainfall at 10-minute rainfall intensities that were mostly less than $20 \mathrm{~mm} / \mathrm{hr}$ (fig. 15B). Rainfall here has an exponential pattern of hours above a given 10-minute threshold intensity (fig. 16), a useful pattern for comparing hours of potential runoff between storms. Figure 17 illustrates 

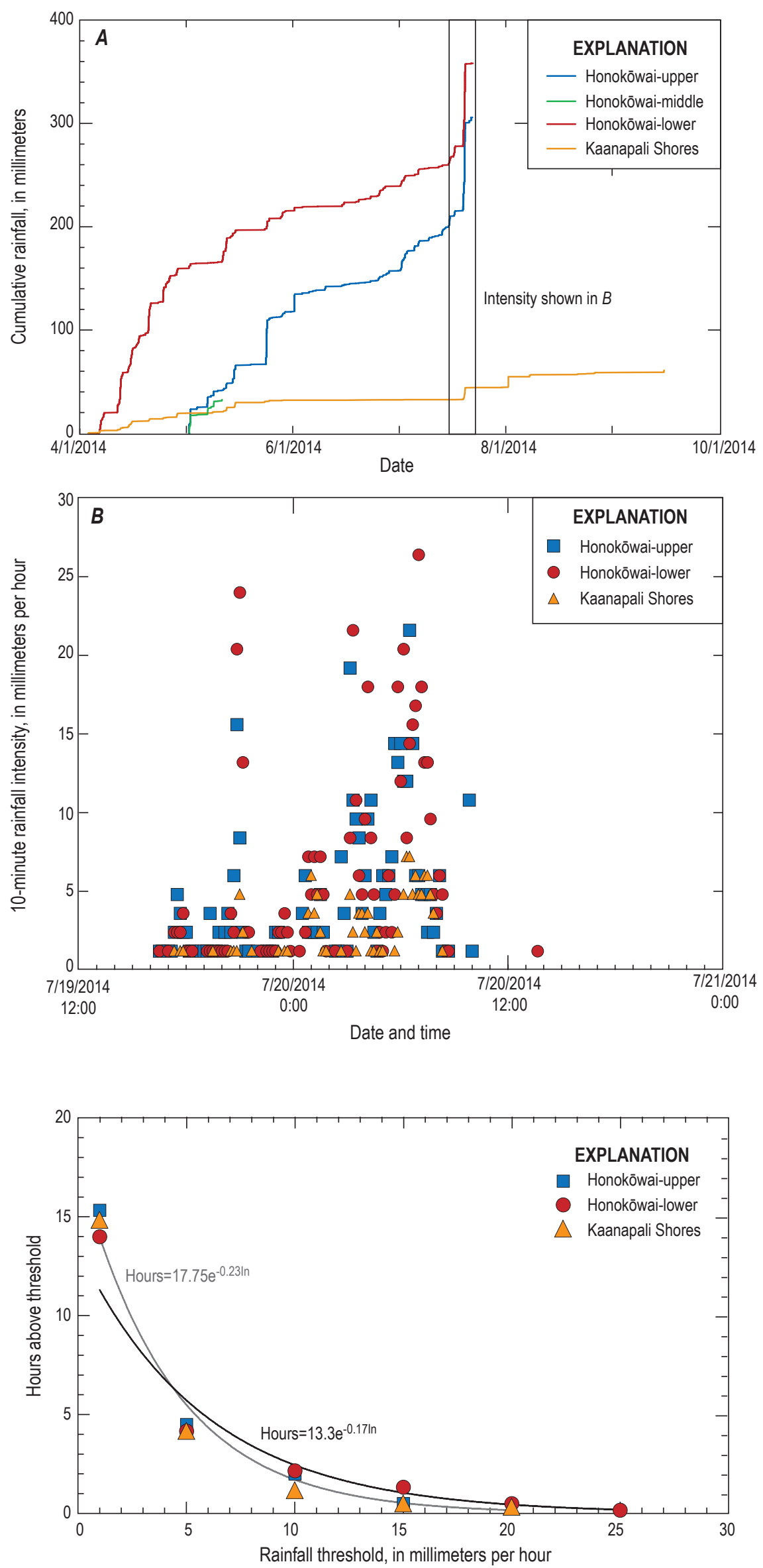

Figure 15. Plots of West Maui rainfall. A, Cumulative rainfalls for West Maui gages at locations shown in figure 9. These Onset RG3m tipping-bucket rain gages were installed in spring of 2014 by Tova Callender. Data loss abbreviates the Honokōwai-middle record. Rainfall totals for July 19-20, 2014, were roughly equivalent for the noncoastal gages (Honokōwai-upper was 67 millimeters [mm], Honokōwai-lower was 80 mm) and much less at Aston Kaanapali Shores hotel on the coast $(23 \mathrm{~mm})$. B, Rainfall intensities at 10-minute discretization recorded by tipping-bucket gages during the storm of July 19-20, 2014. The upper two gages peak at intensities of about 25 millimeters per hour ( $\mathrm{mm} / \mathrm{hr})$. The coastal gage intensities did not exceed $10 \mathrm{~mm} / \mathrm{hr}$. Rainfalls of $10-25 \mathrm{~mm} / \mathrm{hr}$ at noncoastal gages occurred from 06:00 to 08:00 HST, triggering coastal plumes.

Figure 16. Plot showing cumulative exceedance rainfall intensities for tipping-bucket gages. Data can be approximated by an exponential function with two parameters. Coastal rain gage at Aston Kaanapali Shores hotel has lower rainfall intensities, which lower its rainfall total. The two-parameter exponential function is useful to characterize rainfalls, illustrating hours of likely runoff if the saturated hydraulic conductivity of a surface is known. Curves are fitted to Honokōwailower (lower equation) and Honokōwai-upper (upper equation). 

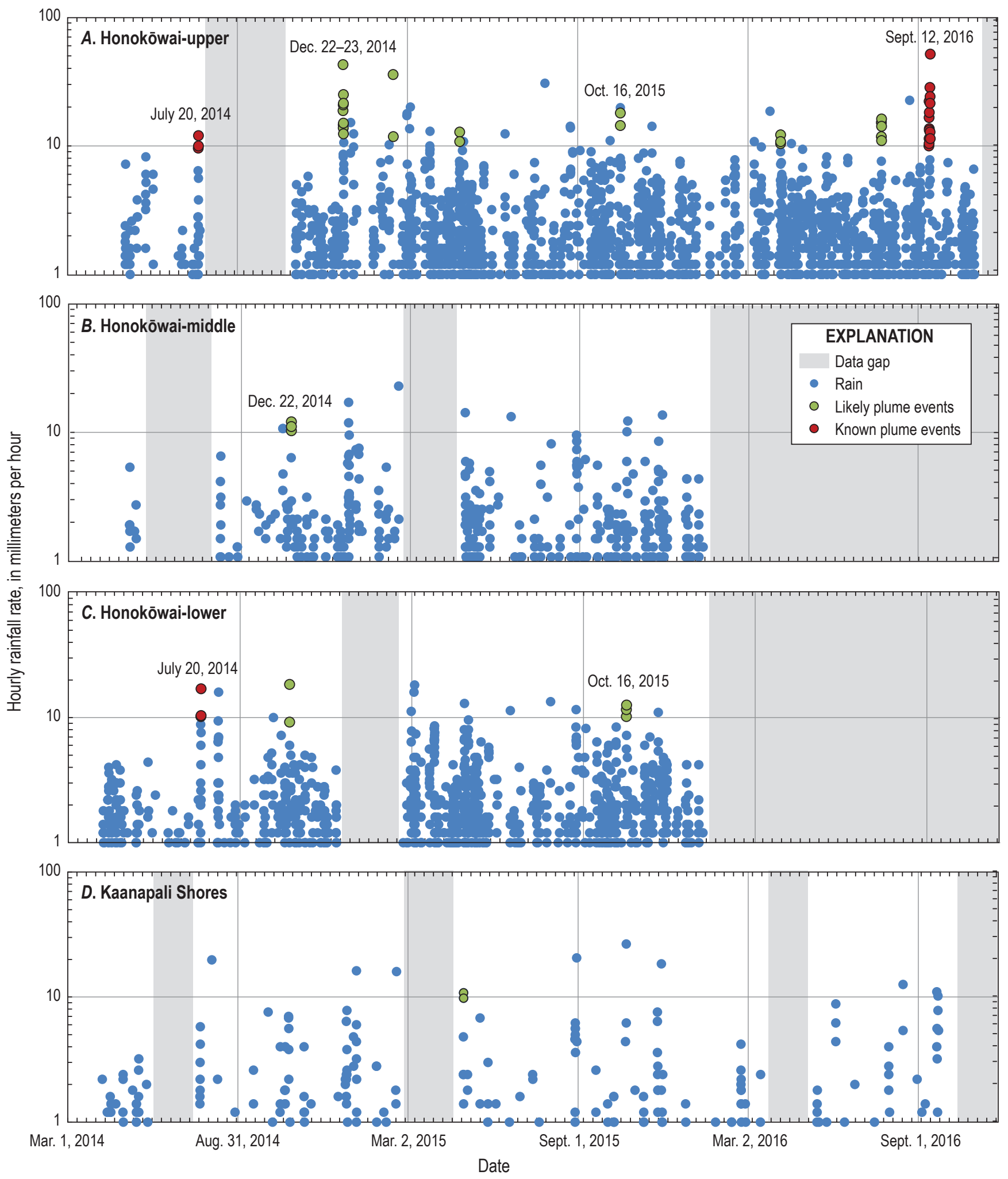

Figure 17. Four plots of hourly rainfall intensity for tipping-bucket rain gages in West Maui (fig. 9), from May 2014 to October 2016: $A$, upper Honokōwai watershed; $B$, middle Honokōwai watershed; $C$, lower Honokōwai watershed; $D$, Kaanapali Stream watershed. Red dots show rainfall intensities known to have coincided with coastal plumes on July 20, 2014, and September 12, 2016 (fig. 1). These rainfalls are all above 10 millimeters per hour ( $\mathrm{mm} / \mathrm{hr}$ ) for more than 1 hour. Green dots show likely plume-generating rainfalls that exceeded the $10 \mathrm{~mm} / \mathrm{hr}$ threshold for more than an hour. The plots suggest that West Maui has experienced nine plumes of varying magnitude over 2014-2016, approximately 4-5 plumes per year. 
the longer record of hourly rainfall intensities measured by tipping-bucket gages to 2016 . The July 2014 plume was generated by rainfalls with peak hourly intensities exceeding $10 \mathrm{~mm} / \mathrm{hr}$ for at least 2 hours in the Honokōwai Stream watershed.
Similar plumes occurred at the mouths of many West Maui streams (figs. 18, 19). Beginning at 13:10 HST on July 20, 2014, about 5-6 hours after the most intense rainfalls, author Stock visited all discharging streams (figs. 20, 21). The color and intensity of the sediment plumes varied from

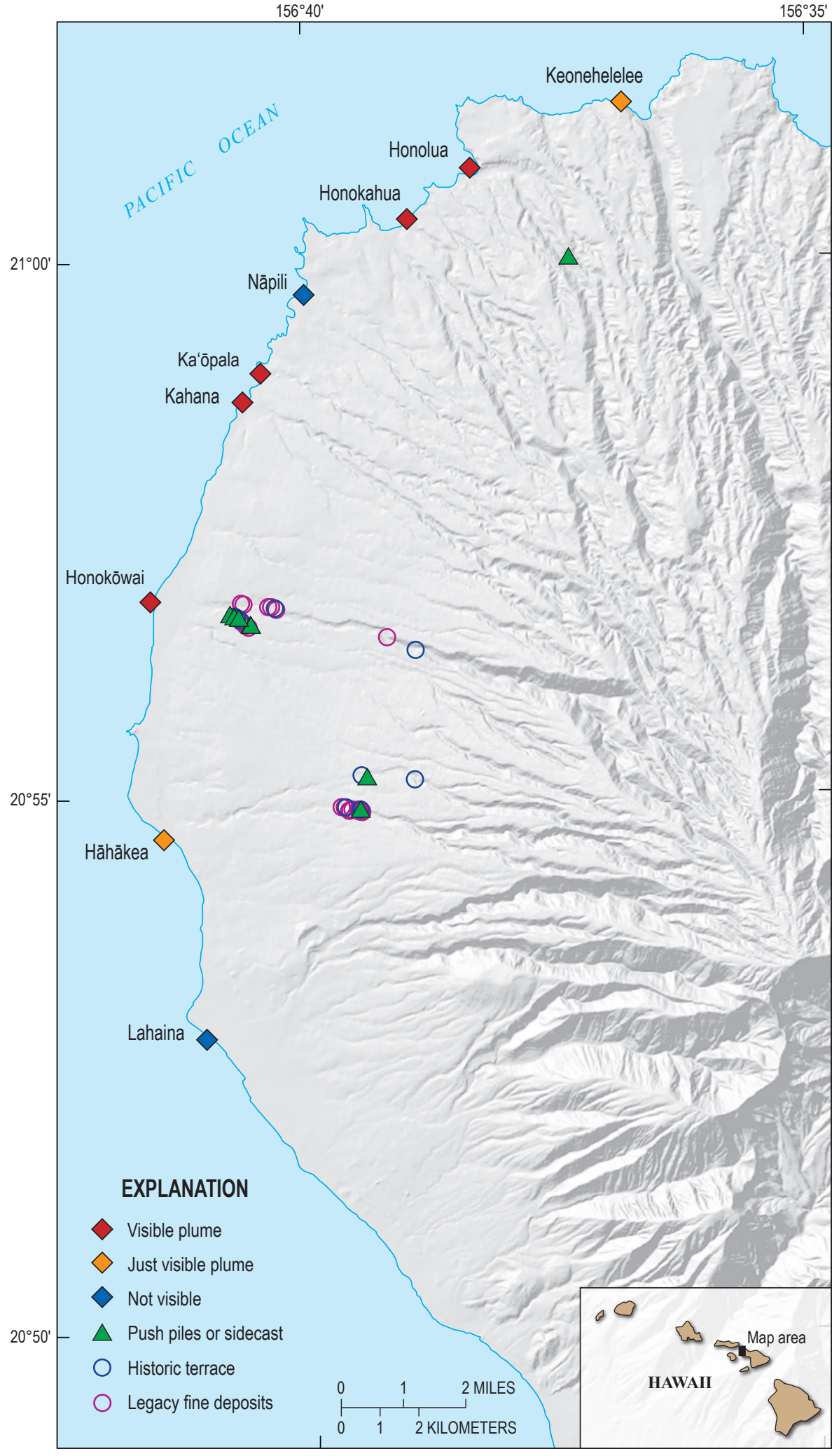

Figure 18. Map showing locations of coastal plumes (diamond) observed by Stock on July 20, 2014, 13:00-18:00 HST (Hawaii Standard Time). Intense rainfalls occurred from about 06:00 to 08:00 HST (fig. 15B), 5-7 hours prior to the beginning of these observations. The most turbid runoff occurred south of Honolua and north of Honokōwai. Nāpili Bay lacked a plume because the turbid stream draining into it lacked sufficient discharge to breach a blocking sand berm. Other symbols show potential sources of fine sediment observed following the plume, including sidecast from agricultural practices, historic fill terraces, and other legacy deposits from human activity. Erosion from these sources of fine sediment may generate coastal plumes at low stream flow. 


\section{A. Keonehelelee (east)}

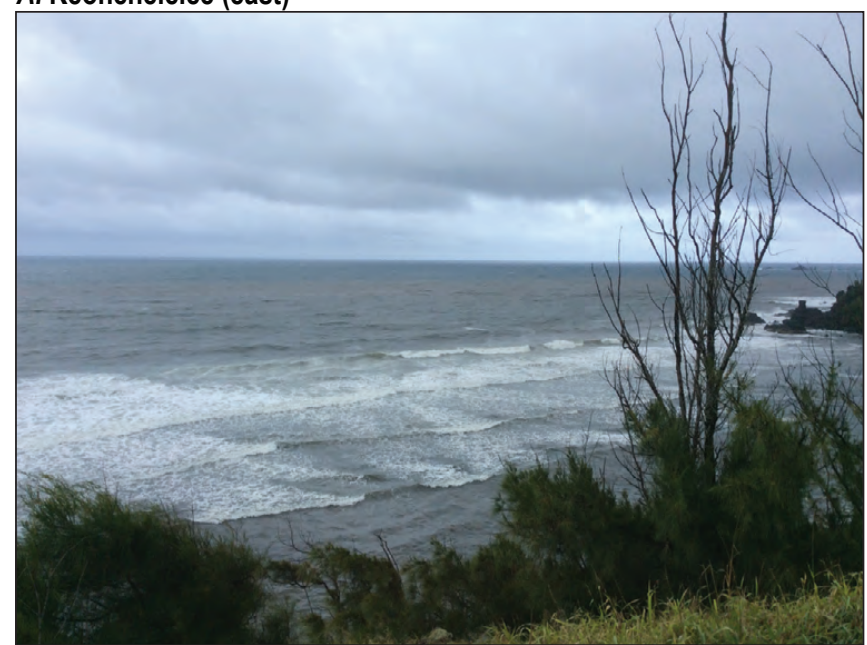

\section{Honolua Stream}

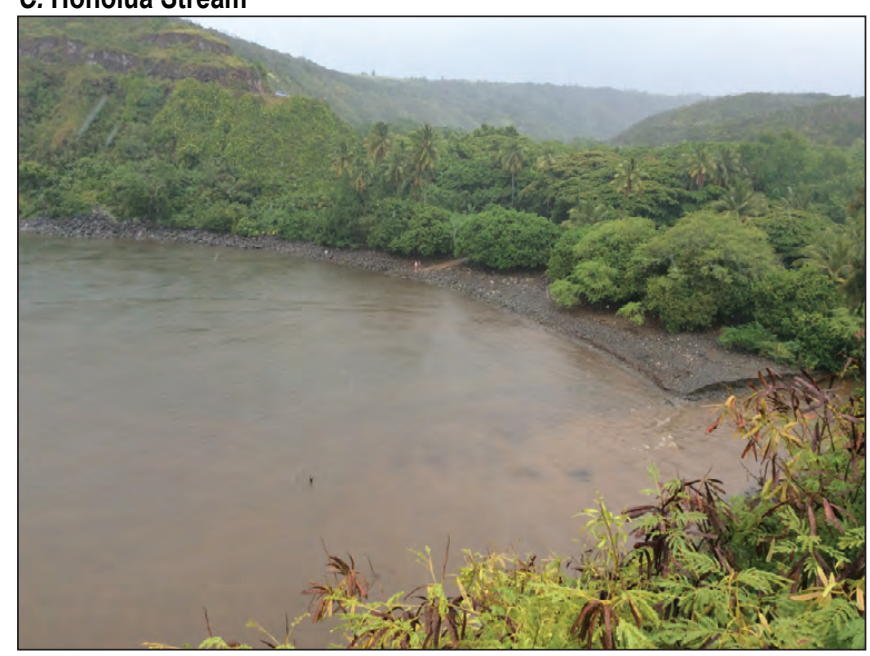

\section{E. Fleming}

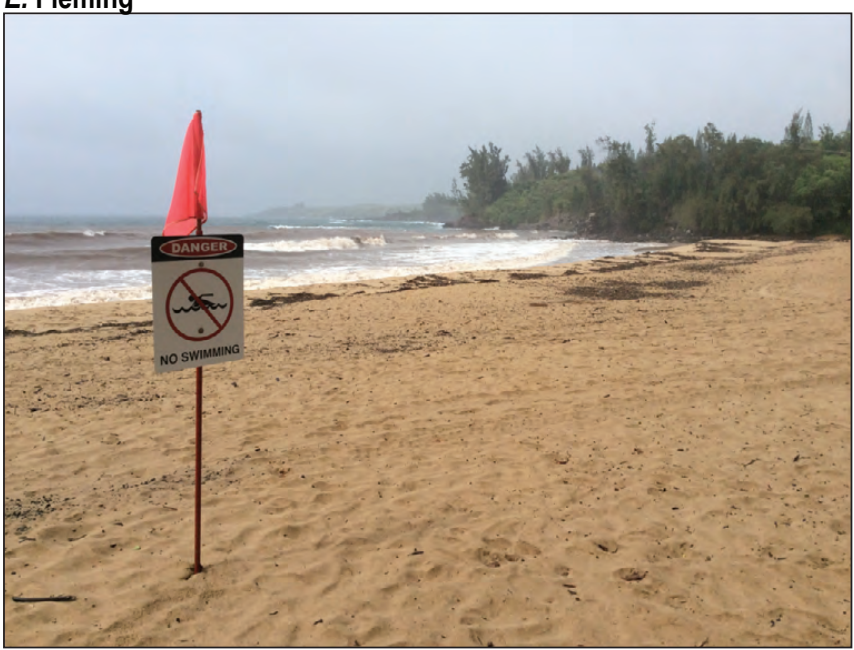

\section{B. Keoneheelee (west)}

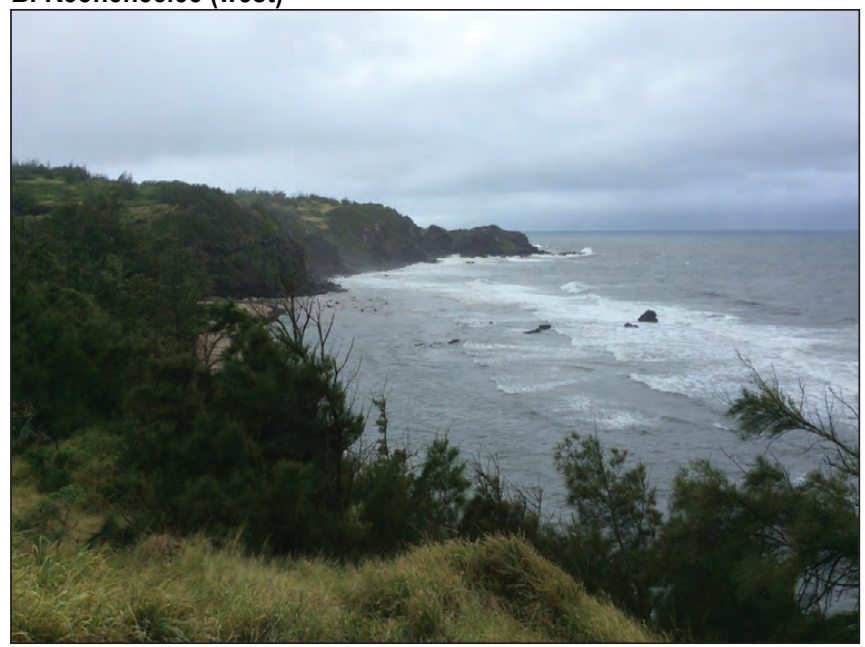

\section{Honokahua Stream}

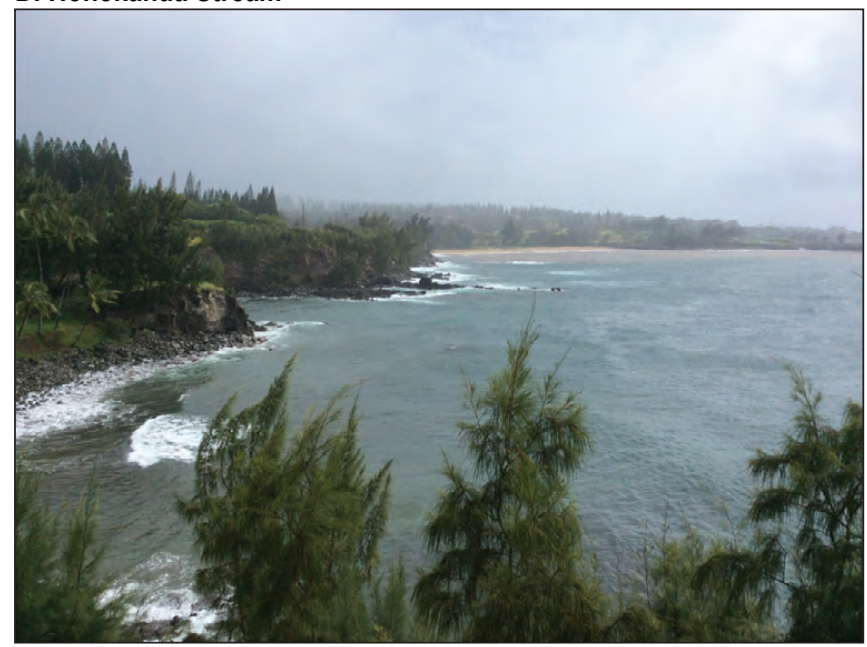

F. Nāpili 4-5

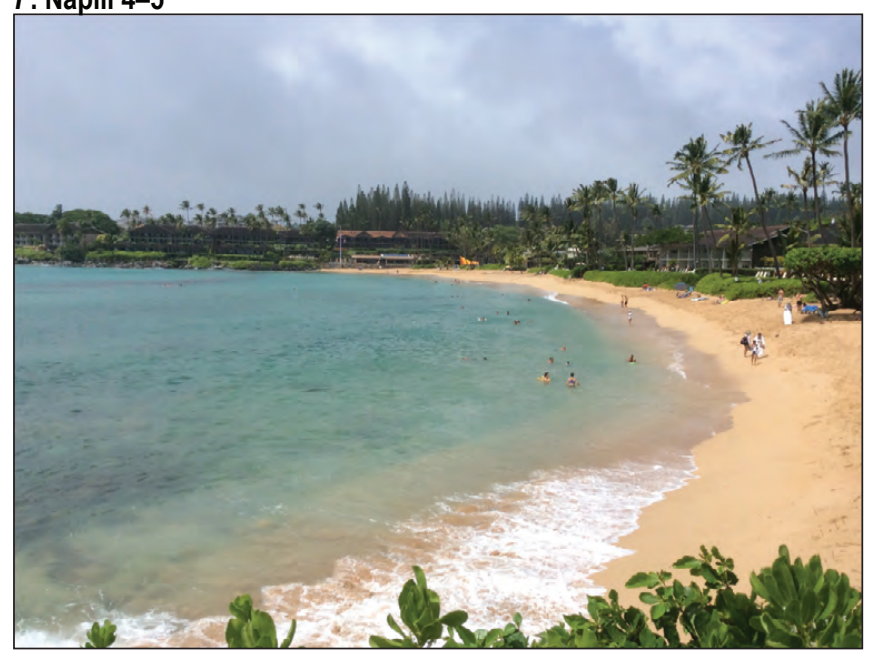

Figure 19. Photographs of West Maui coastal plumes (from north to south) observed July 20, 2014, 13:00-18:00 Hawaii Standard Time (A-K) and July $30(L)$. A, Looking east of Keonehelelee. Plume is defined by a water color difference near horizon. $B$, Looking west of Keonehelelee. No obvious plume. C, Honolua Bay. Plume at stream mouth as muddy water. D, Honokahua Bay. Plume in distance. E, D.T. Fleming Beach Park. $F$, Nāpili Bay. No plume. 


\section{G. Ka'ōpala Gulch (north)}

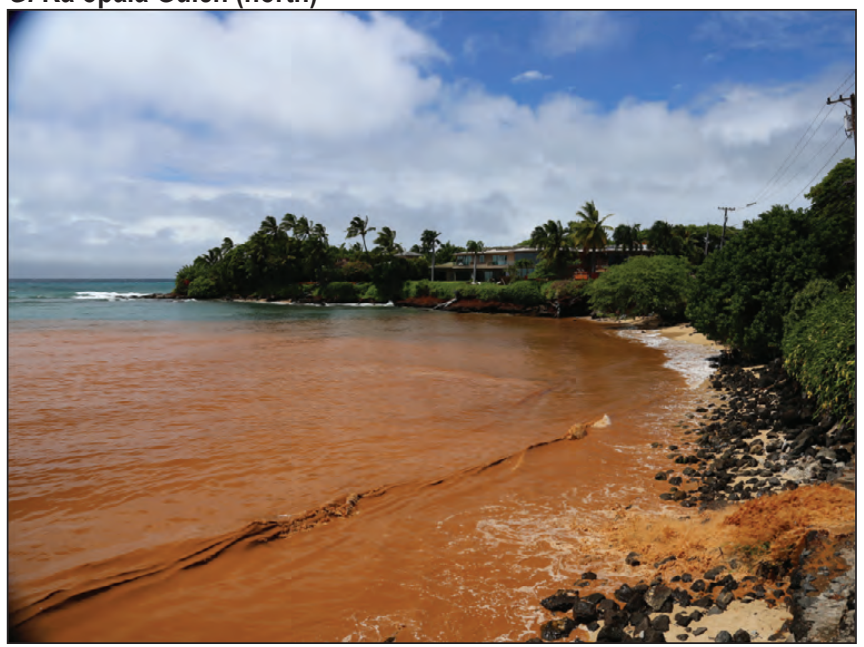

I. Ka'ea

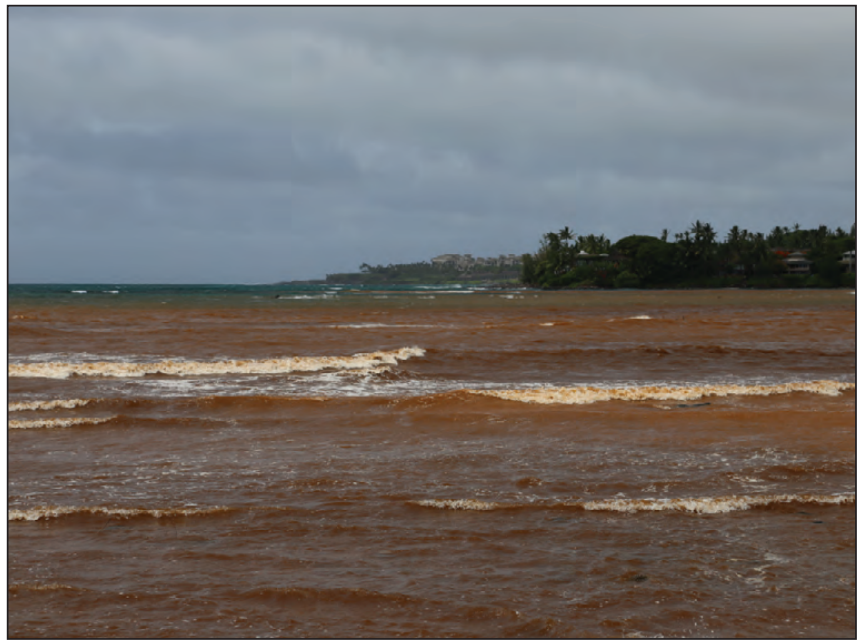

K. Honokōwai Stream

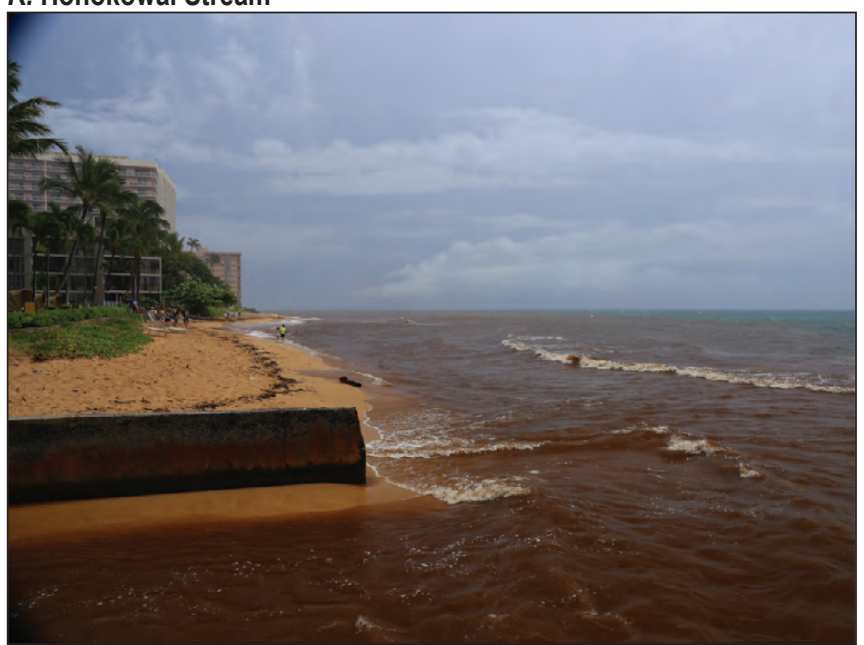

H. Ka'ōpala Gulch (south)

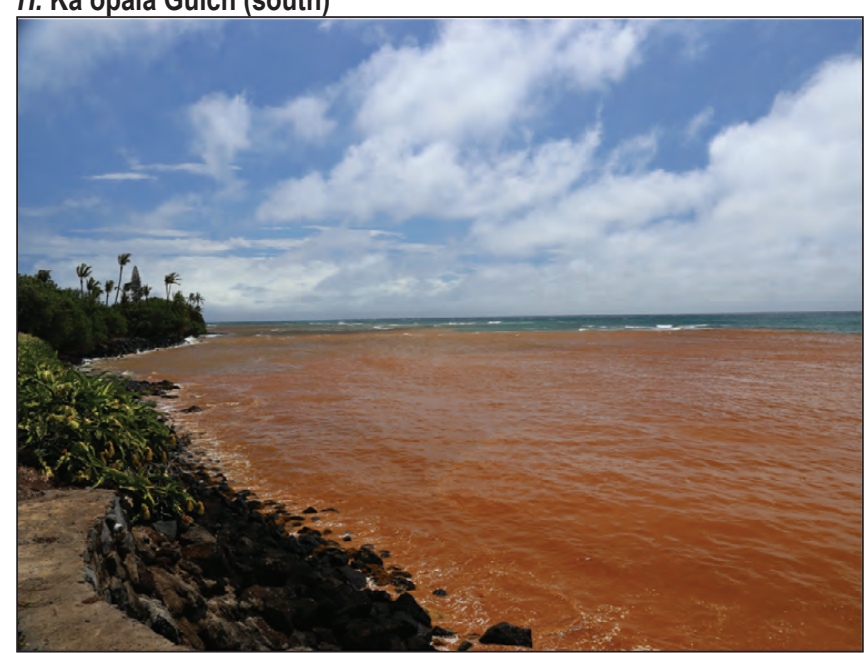

\section{J. Kahana Stream}

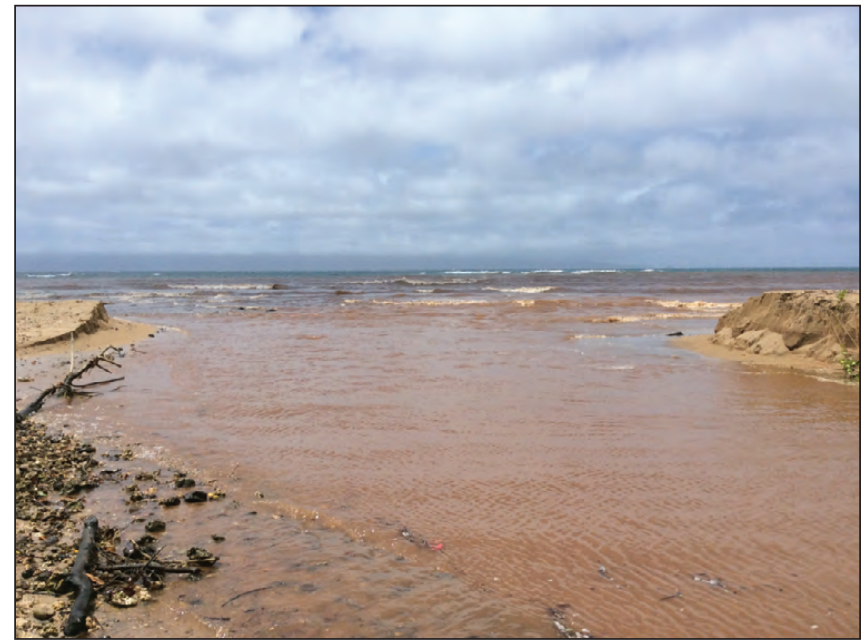

L. Honokōwai Stream (south)

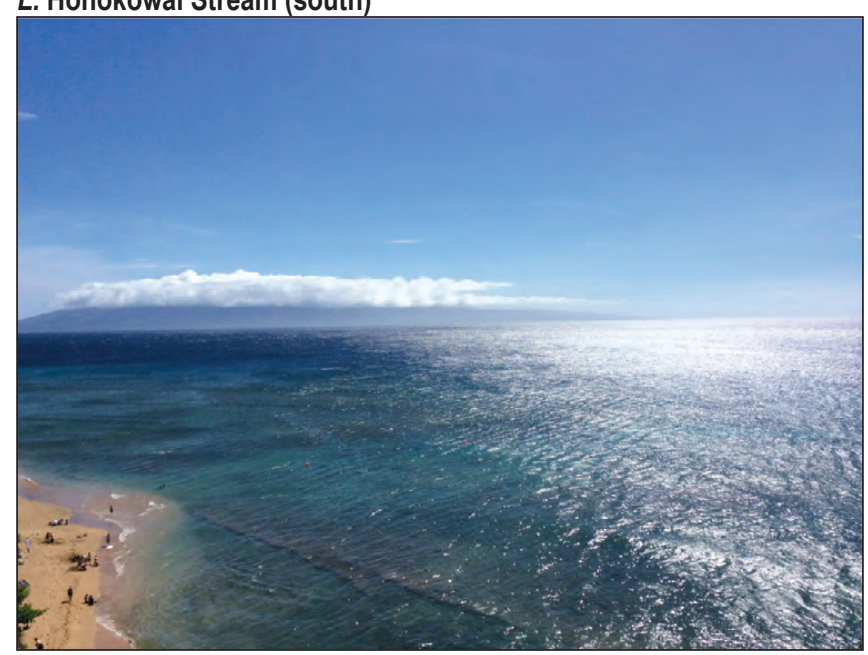

Figure 19.-Continued. Photographs of West Maui coastal plumes (from north to south) observed July 20, 2014, 13:00-18:00 Hawaii Standard Time $(A-K)$ and July $30(L)$. G, Ka'ōpala outlet looking north. H, Ka'ōpala outlet looking south. I, Ka'ea Point looking north. J, Kahana Stream outlet. K, Honokōwai Stream outlet. L, Looking south from Honokōwai. Sediment plume remaining 10 days after July 19-20 event. 


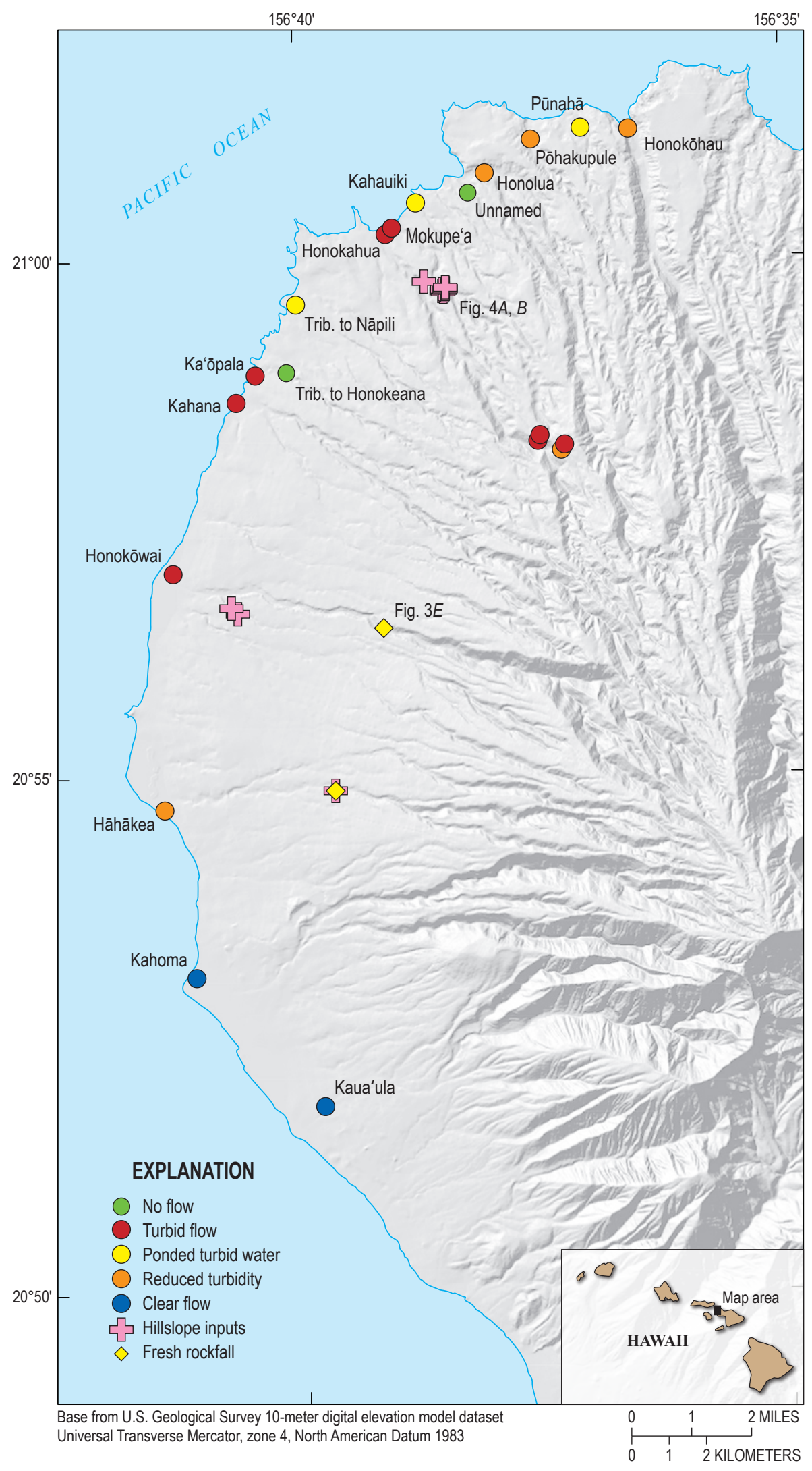

Figure 20. Map showing locations of streamsediment pollution observed by Stock on July 20, 2014, 13:00-18:00 Hawaii Standard Time, following the July 19-20 storm. The most turbid runoff occurred in streams between Honolua and Honokōwai. In these streams, we observed orange- or red-orangecolored turbidity. Streams with reduced turbidity had brown-colored suspended sediment. Intense rainfalls occurred from 06:00 to 08:00, 5-7 hours prior to the beginning of these observations (fig. 15B). Hillslope inputs included fine sediment from overland flow and small gullies active during or after the storm, as observed on July 20, 2014. Fresh rockfalls may have been triggered by this storm (for example, fig. 4). This comparatively small storm created sediment plumes along West Maui's northwest coast (fig. 19). Trib., tributary. 


\section{A. Honokōhau Stream}

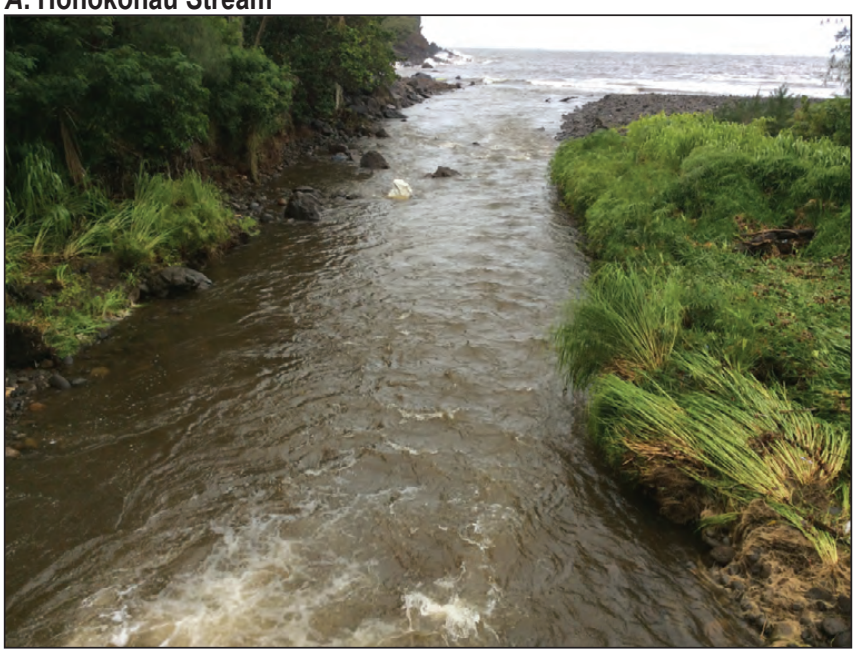

\section{Pōhakupule Gulch}

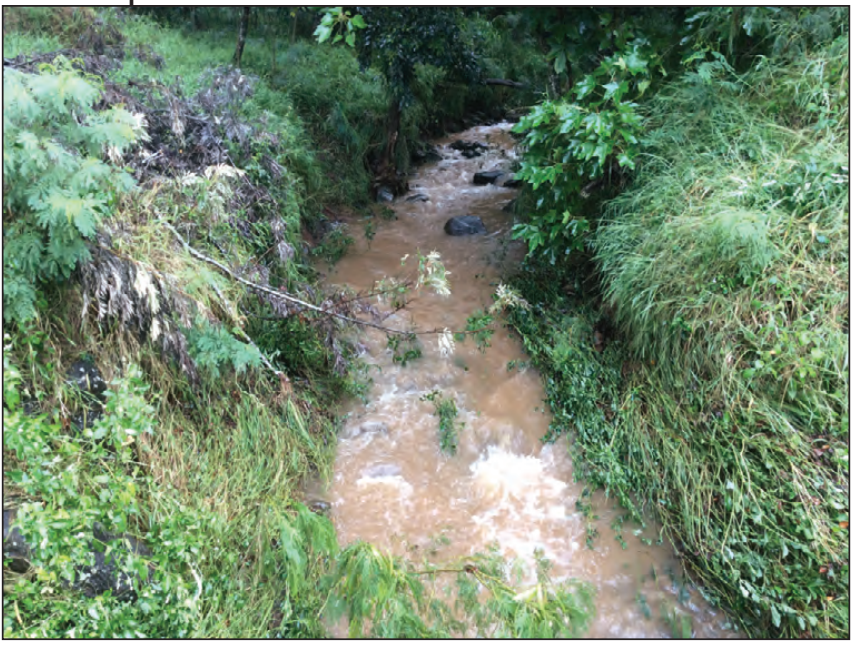

E. Unnamed

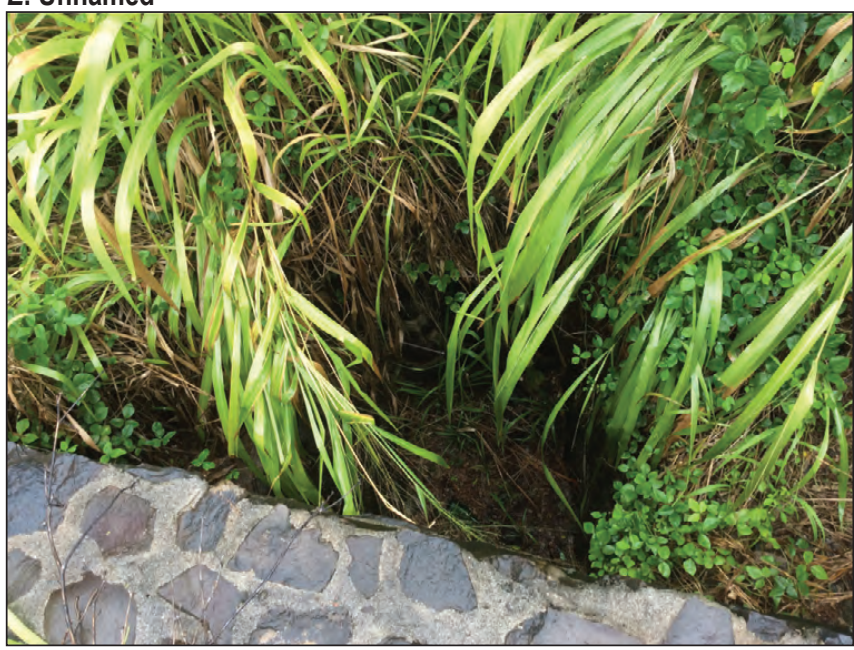

B. Pūnahā Gulch

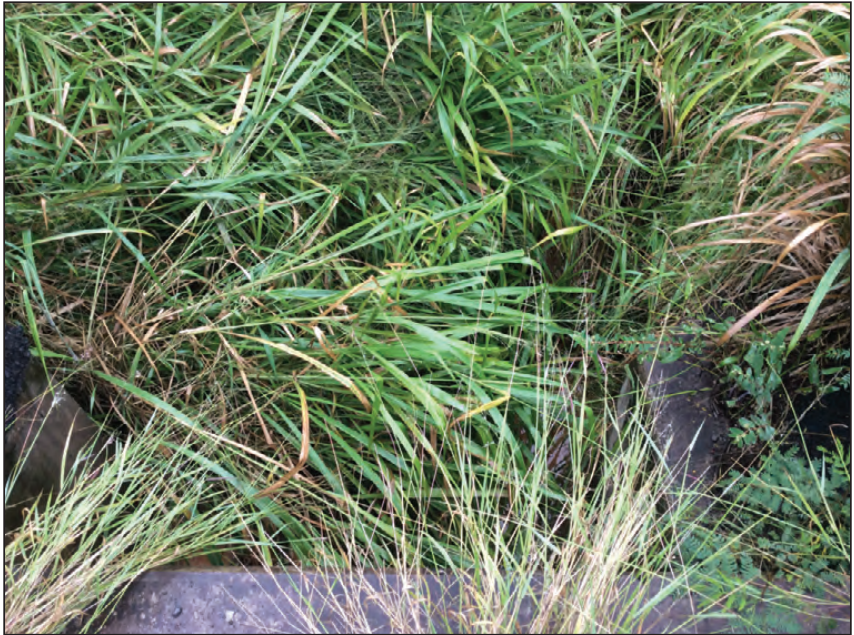

\section{Honolua Stream}

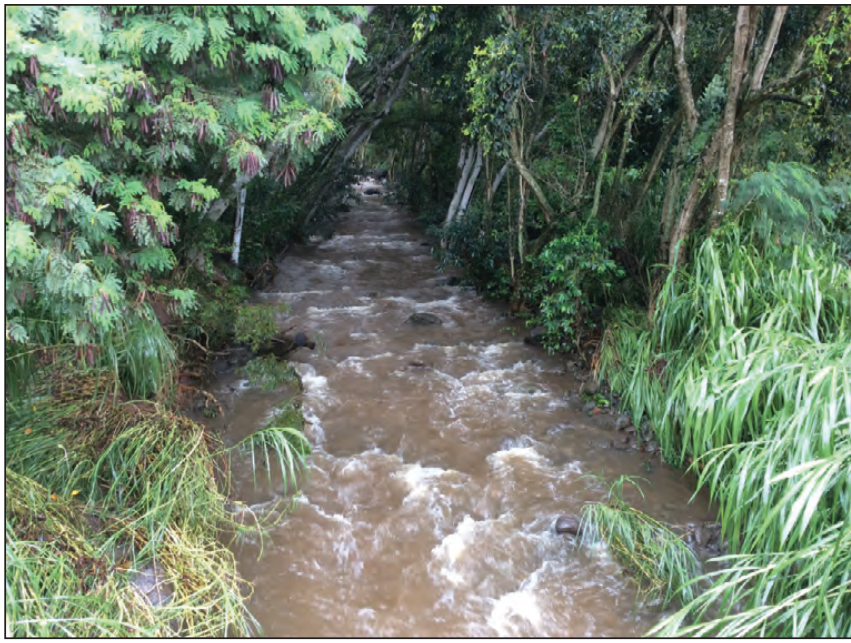

F. Kahauiki Gulch

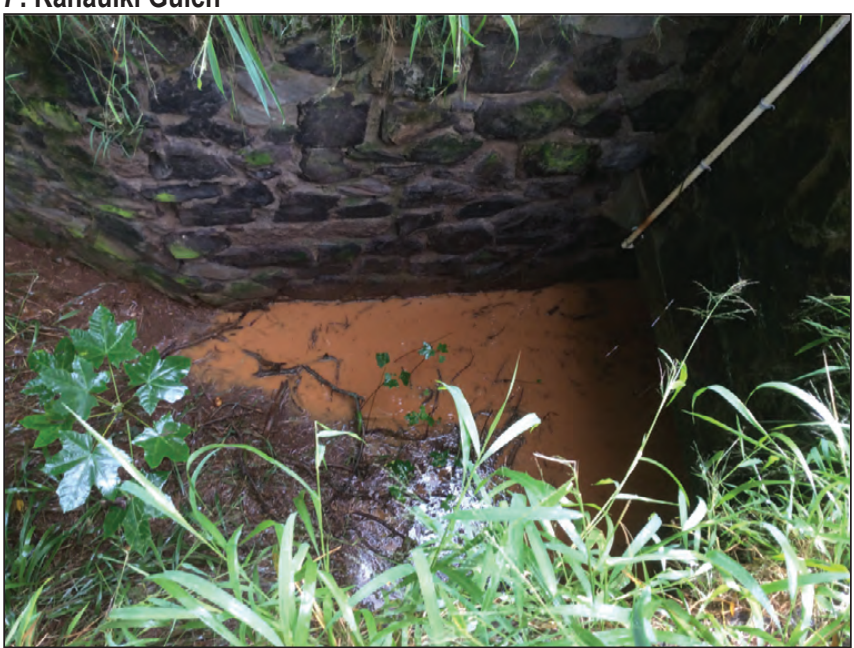

Figure 21. Photographs of suspended sediment in West Maui streams (from north to south), observed July 20, 2014, 13:00-18:00 Hawaii Standard Time. A, Honokōhau Stream. B, Pūnahā Gulch. C, Pōhakupule Gulch. D, Honolua Stream. E, Unnamed tributary to Honolua Bay near Honokohau Street. F, Kahauiki Gulch. 

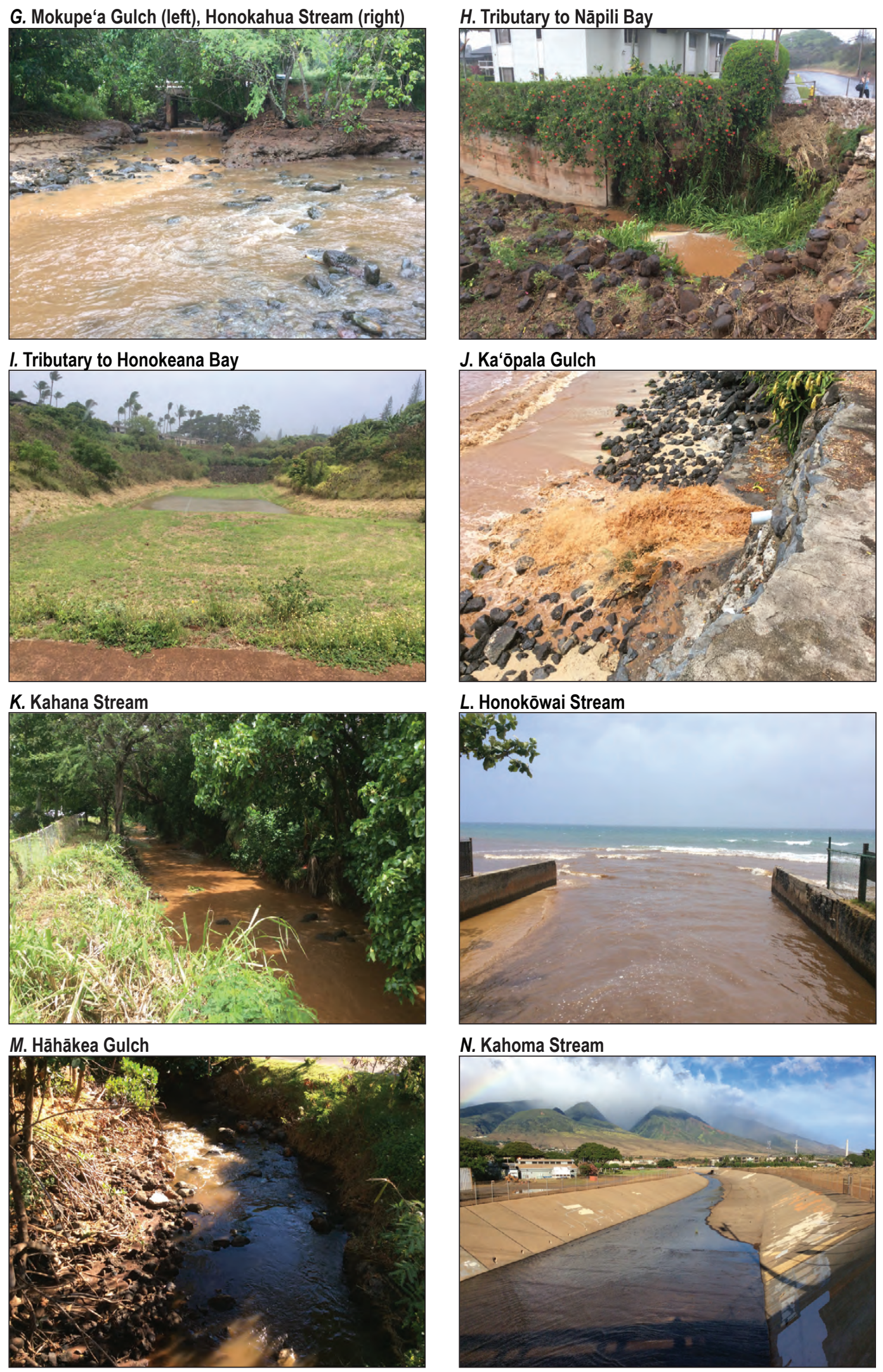

Figure 21.-Continued. Photographs of suspended sediment in West Maui streams (from north to south), observed July 20, 2014, 13:00-18:00 Hawaii Standard Time. G, Confluence of Honokahua Stream (right) and Mokupe'a Gulch (left). H, Tributary gulch to Nāpili Bay. I, Tributary gulch to Honokeana Bay. J, Ka'ōpala Gulch outlet. K, Kahana Stream. L, Honokōwai Stream; M, Hāhākea Gulch outlet $\sim 10 \mathrm{~m}$ inland from coast. N, Kahoma Stream from Front Street bridge in Lahaina. The highest visual sediment concentrations from this storm are in streams between Kahauiki Gulch $(F)$ and Honokōwai Stream (L). 
low-intensity, brown-tea colors in the northernmost runoff, to progressively more red orange toward $\mathrm{Ka}^{6} \bar{o}$ pala Gulch, and turning to brown at Honokōwai Stream, the southernmost observed runoff.

Rainfalls of July 19-20, 2014, did not produce widespread overland flows in fields or roads (see, for example, fig. 10B). In the fields, we observed evidence of patches of road runoff that produced flow, which then dissipated in the fields. We did not observe unconfined flow, rills, or gullies moving water from former fields to channels. Unimproved roads cross the low-relief flow slopes of West Maui. Some have runoff-limiting structures, such as water bars, coupled berms, and troughs that funnel flow off of the road (fig. 5C). Road surfaces are composed of red-orange airfall deposits of varying compaction. Long-used roads, such as the Honokōwai ridge road in figure $10 \mathrm{~A}$, have compacted to dense layers. These surfaces generated runoff during the July 19-20 storm, and we observed local accumulations of sediment in ponded areas behind water bars. We did not see any of these roadways dumping sediment and water into streams, but that is possible.

Abandoned trails and roadways are found along ridges and on margins of flow slopes. Some watersheds contain a network of active dirt-bike trails on ridges and along streams. Trail and roadway features are distinguished by bare surfaces, which may be incised meters below original top soils. Bare patches on the margins of these features record erosion by concentrated flow (fig. $5 B$ ) or shallow landslides. In some locations, the landslides appear to occur in old-road sidecast made of nonsorted colluvium with burnt vegetation fragments (for example, figs. $5 E, F$ ).

The agricultural ditch system that brings water from within the Honolua watershed to the Wahikuli watershed was observed to be eroding where the ditch system was unlined. Wahikuli Reservoir was decommissioned and breached in 2013; the remaining water in the system is now delivered to Wahikuli gulch and Honokōwai Stream. Ditch water creates flow in streams that is not directly correlated with rainfall events.

\section{Infiltration Rates}

Infiltration rates from fields and roads of West Maui (fig. 9; table 3) range from 12 to $93 \mathrm{~mm} / \mathrm{hr}$. This range is consistent with values found for agriculturally treated soils on $\mathrm{O}^{\prime}$ ahu, which are between 11 and $85 \mathrm{~mm} / \mathrm{hr}$ if four outlying points are excluded (table 4 in Green and others, 1982). Machine-disked pineapple fields in West Maui encompass this full range, although the majority of rates are greater than $25 \mathrm{~mm} / \mathrm{hr}$. The absence of widespread runoff from fields after rainfalls of July 19-20, 2014, (for example, fig. 10B) is consistent with the fact that rainfalls did not exceed $\mathrm{K}_{\text {sat }}$ values of table 3 . The absence of valley networks cut into these features over the past 1.1-1.3 m.y. is also consistent with saturated hydraulic conductivities that often exceed rainfall intensities. Saturated hydraulic conductivities from unimproved dirt roads, both loose and compacted, ranged from 30 to $56 \mathrm{~mm} / \mathrm{hr}$. The average airfall deposit in West Maui's agricultural fields is a loamy sand (median grain size of $0.2 \mathrm{~mm}$ ) with a saturated hydraulic conductivity of $\sim 50 \mathrm{~mm} / \mathrm{hr}$ (table 3 ) and is composed of 82 percent sand, 16 percent silt, and less than

3 percent clay by volume (figs. 22, 23; table 4). They are coarser than illustrative airfall deposits from the Island of Hawai' $i$ (dashed red curve in fig. 23) and have much less silt than fill-terrace deposits (fig. 22).

\section{Rainfall Analysis}

Figure 17 illustrates that, when rainfalls above $\sim 10-20$ $\mathrm{mm} / \mathrm{hr}$ persist for two or more hours, sediment plumes appear at the coast. There have been nine events above this threshold (see figs. 17A,B, in particular) over two years of rainfall record, or $4-5$ events per year. It is possible that even lower-intensity rain would also trigger plumes, if stream flow is sufficiently deep to erode fill terraces. The $10-20 \mathrm{~mm} / \mathrm{hr}$ threshold is below almost all saturated hydraulic conductivity values in table 3 , so it is unlikely that runoff from agricultural fields generates these plumes.

Historic rainfall records tell us when and how often these thresholds were breached in the past (appendix tables 1.1 to 1.8). Rain gages from the uplands of West Maui show that, over the past three decades,

1. annual rainfall totals have decreased (fig. 24),

2. cumulative hours of rainfall at intensities greater than $20 \mathrm{~mm} / \mathrm{hr}$ have decreased (fig. 25), and

3. the frequency of storms with continuous intense rainfall has not changed (fig. 26).

To summarize, although total rainfall has decreased since the 1970s, more rainfall now occurs during short, intense storms capable of causing runoff and erosion and generating plumes as large as or larger than the July, 2014 event.

Figure 26 (and appendix tables 1.5 to 1.8) show historic events when it rained for more than 1 hour at rates above 20 $\mathrm{mm} / \mathrm{hr}$, a value that likely initiates runoff. We chose $20 \mathrm{~mm} / \mathrm{hr}$ because more than 90 percent of the $\mathrm{K}_{\text {sat }}$ values in table 3 exceed this value, and it is the upper limit of the plumegeneration rainfall intensities in figures 16 and 17. These events represent the storms most likely to generate widespread runoff and erosion. The Lahaina and Field 46 gages recorded about one of these events per year during the 1980s (appendix tables 1.5 and 1.8) and fewer than that during the 1990s. Lahaina had only two events during the 1990s, whereas Field 46 had just less than one per year on average. Greater than $20-\mathrm{mm} / \mathrm{hr}$ storms are less frequent from 1993 to 2001. In the 2000s, Puu Kolii and Field 28 both had about one event per year (appendix tables 1.6 and 1.7).

The very largest storms, with continuous rainfall greater than $40 \mathrm{~mm} / \mathrm{hr}$, would activate runoff at a number of the former agricultural field sites in table 3 . As an example, the 


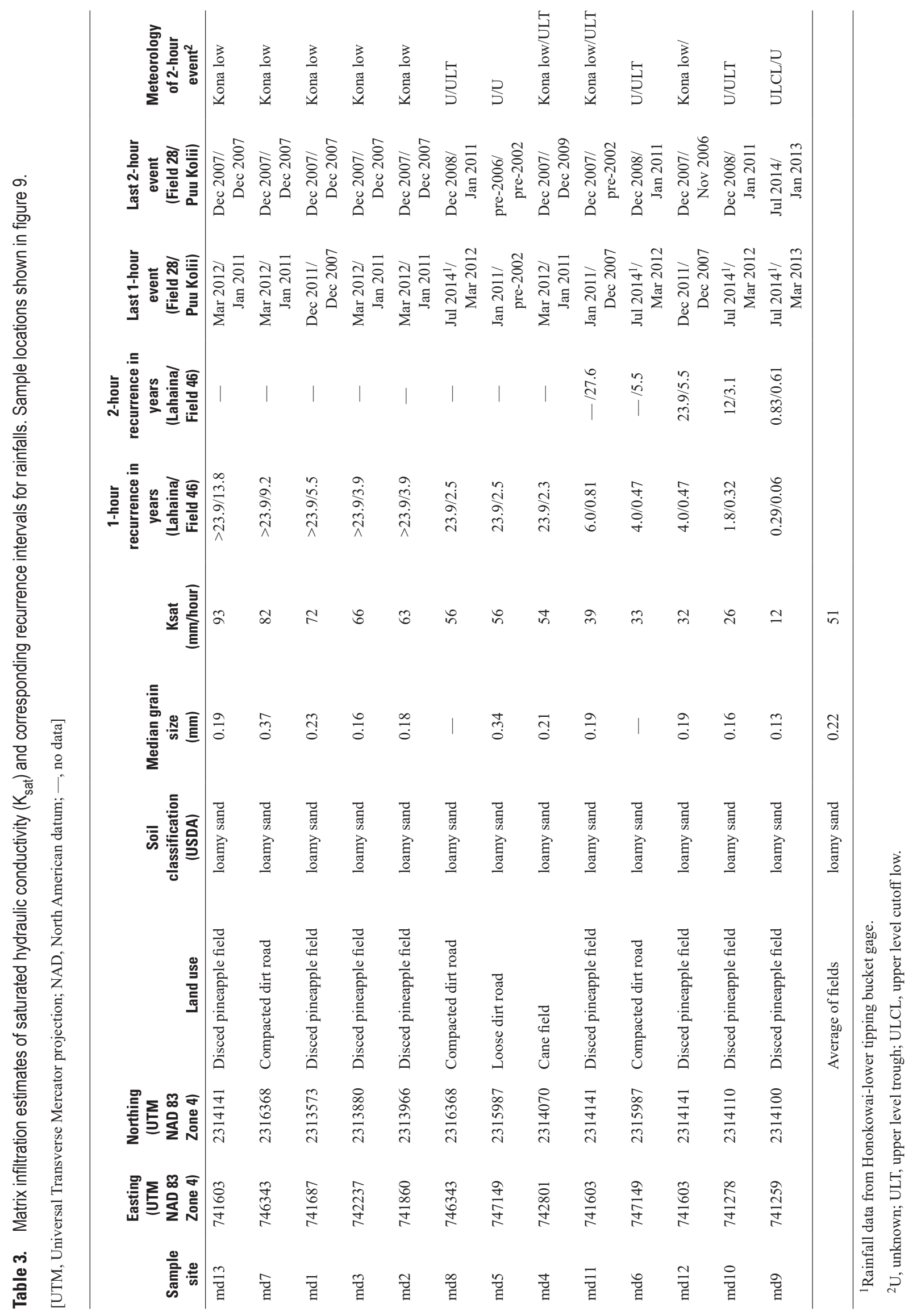




\section{EXPLANATION}

- Historic fill terraces

Airfall modified by agriculture

- Overbank flood deposit from undisturbed watershed

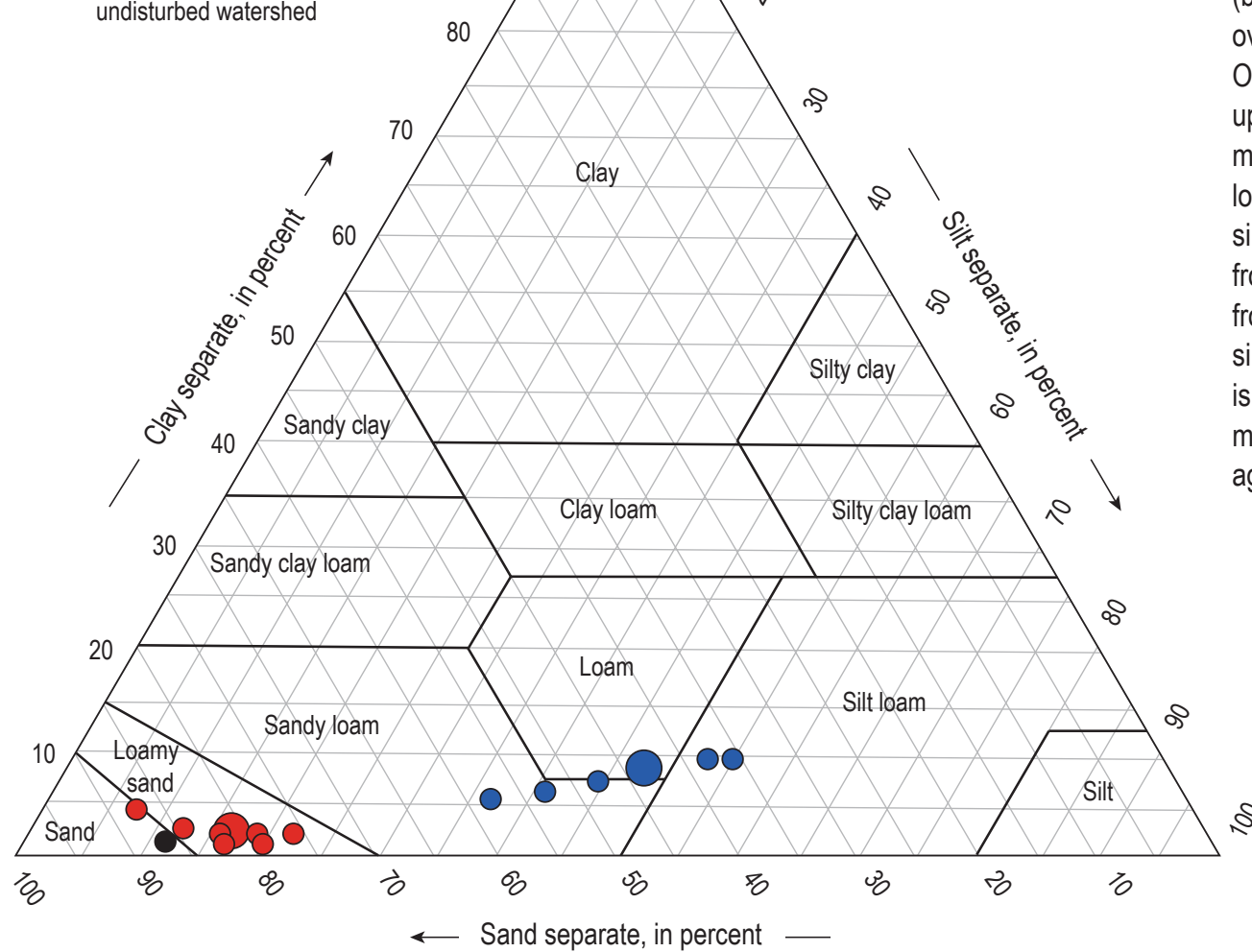

Figure 22. USDA soil classification diagram of potential plume-sediment sources, including airfall from agricultural fields (red dot) and historic fill terraces (blue dot) in watersheds. Black dot shows overbank deposits from a 2017 flood at Olowalu Steam, a catchment with no upstream agriculture. Large circles show mean values of agricultural field airfall (a loamy sand) and historic fill terraces (a silt/sandy loam). The linear trend results from the gradual linear increase in clay from 5 percent to 10 percent by weight as silt content increases. Fill terrace materia is about five times finer (median $=0.04$ millimeter [mm]) than airfall found on agricultural fields (median $=0.22 \mathrm{~mm}$ ).
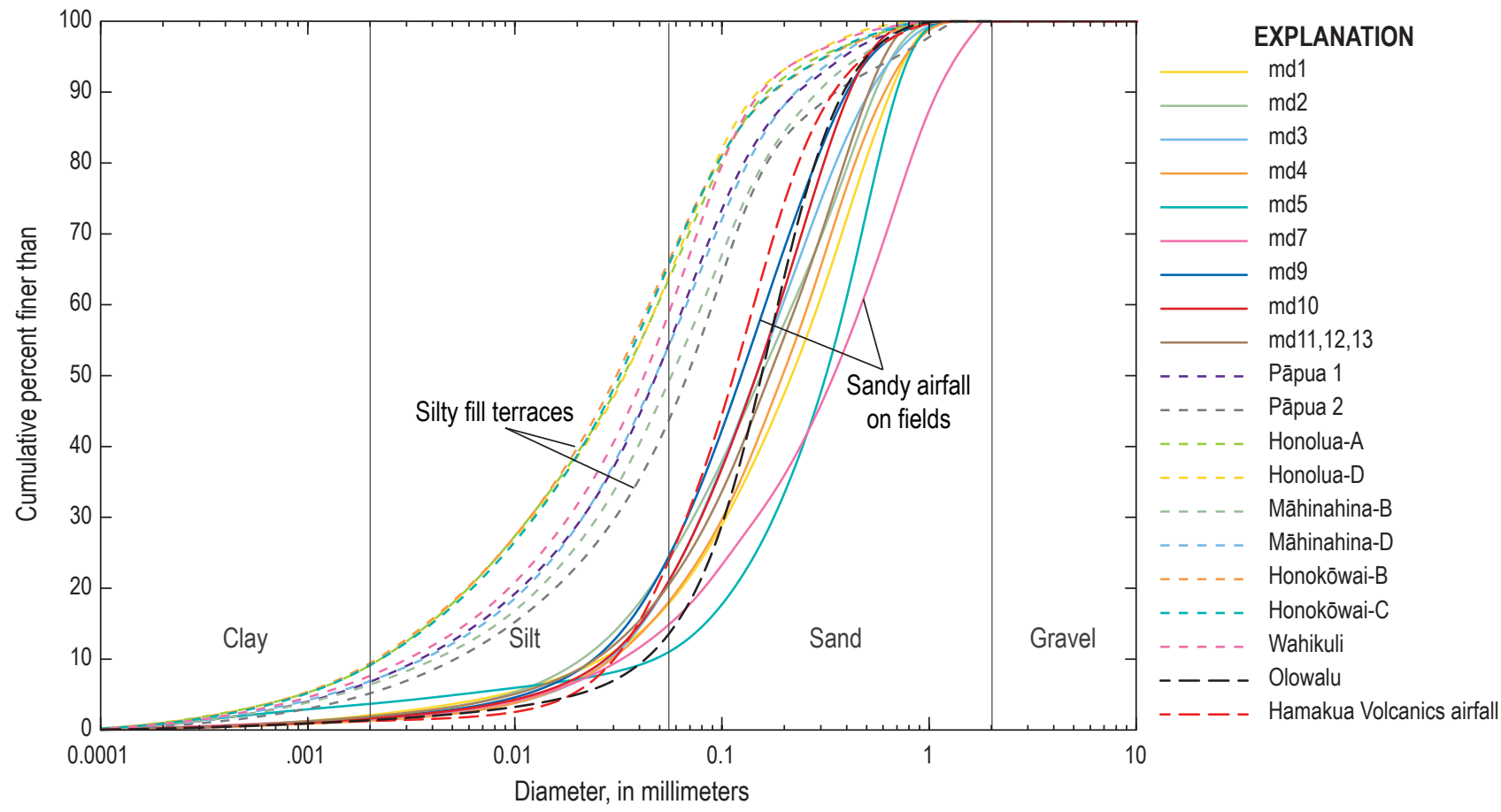

Figure 23. Plot of particle-size distributions of surface soils from infiltration-test sites on fields and roads of West Maui (see fig. 9 for Maui locations, table 4 for values) and historic fill terraces. Airfall deposits capping West Maui are loamy sands (median $=0.22$ millimeter [mm]) with a mean value of 16 percent silt by weight. Historic fill-terrace materials are sandy or silty loams (median $=0.04 \mathrm{~mm}$ ), with a mean value of 45 percent silt by weight. 


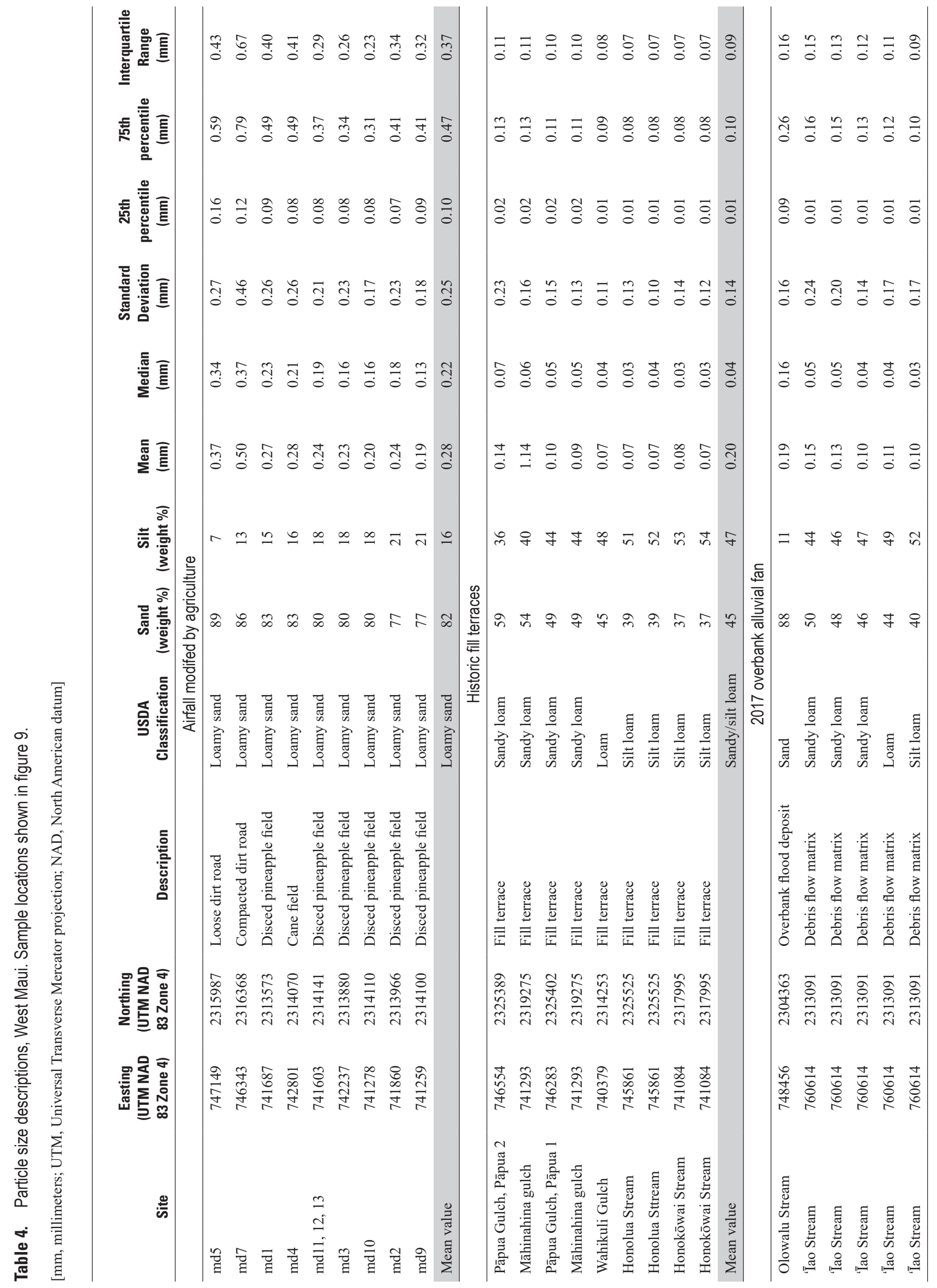




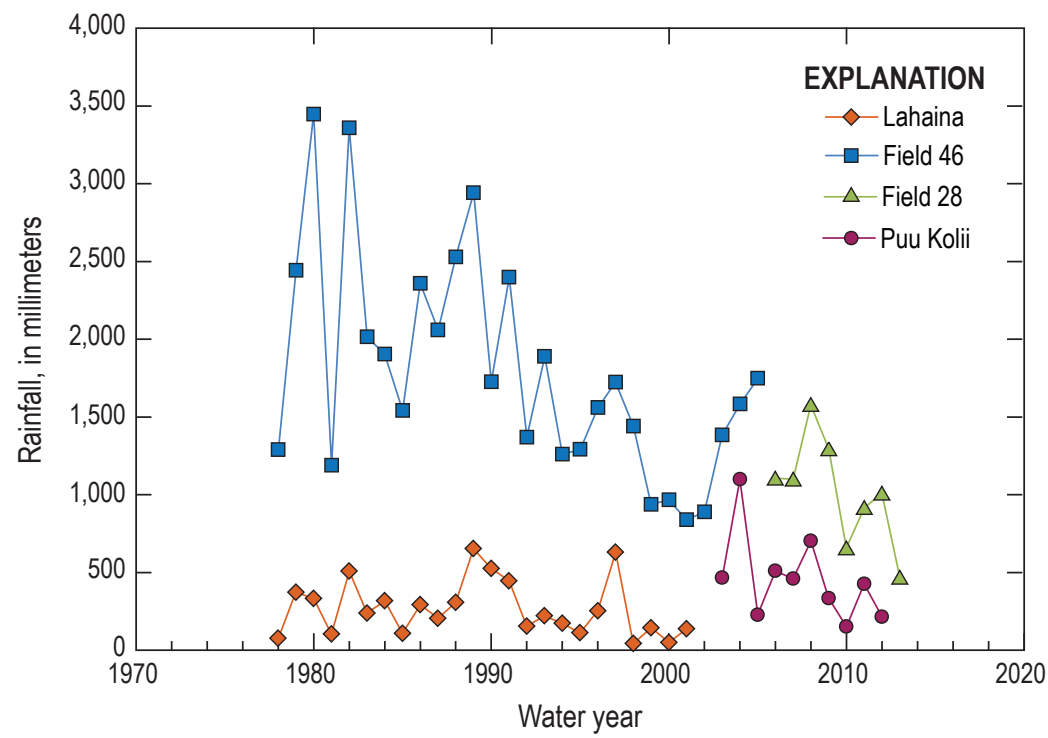

Figure 24. Historic rainfall data from West Maui gages (locations in fig. 9), plotted by water year (starts on October 1). Although there is annual variability, the trend shows that annual rainfall has decreased over the last three decades at the central and northwest gages. There is no evident trend at the arid south-central coastal gage at Lahaina.

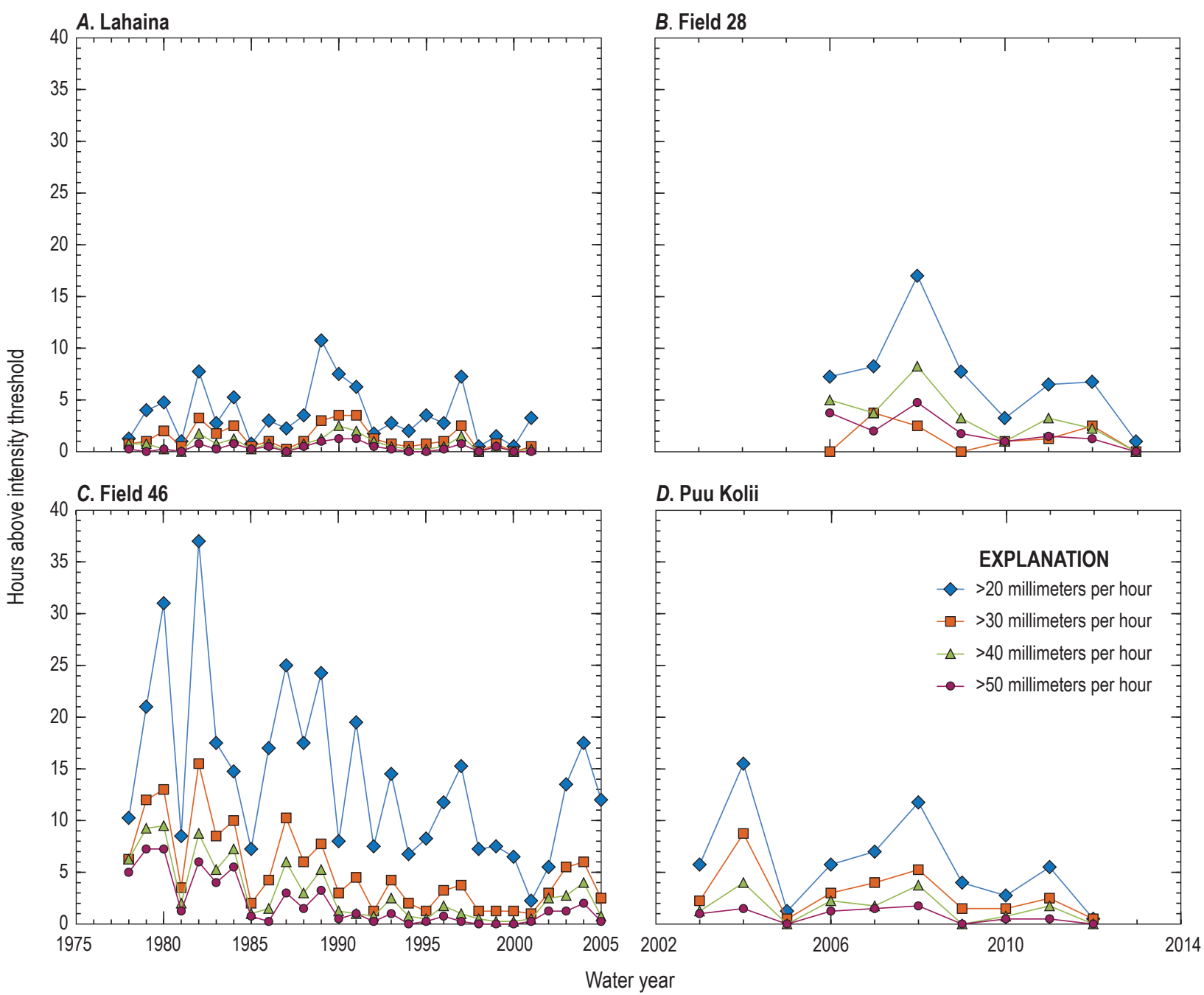

Figure 25. Plot showing the number of hours of rainfall above a given intensity for historic rain gages in West Maui (fig. 9). See appendix for historic storm records corresponding to these graphs. While the Lahaina and Puu Kolii gages show no trend, weak decreases are evident for the more northern gages (Field 28, Field 46). The heaviest rainfalls ( $>20$ millimeters per hour [mm/hr]) seem to occur for 1-11 hours per water year at Lahaina, 1-16 hours at Puu Kolii, 1-18 hours at Field 28, and 2-37 hours at Field 46, generally increasing to the north. This pattern leads to the expectation that rainfalls capable of causing plumes are more common to the north. 


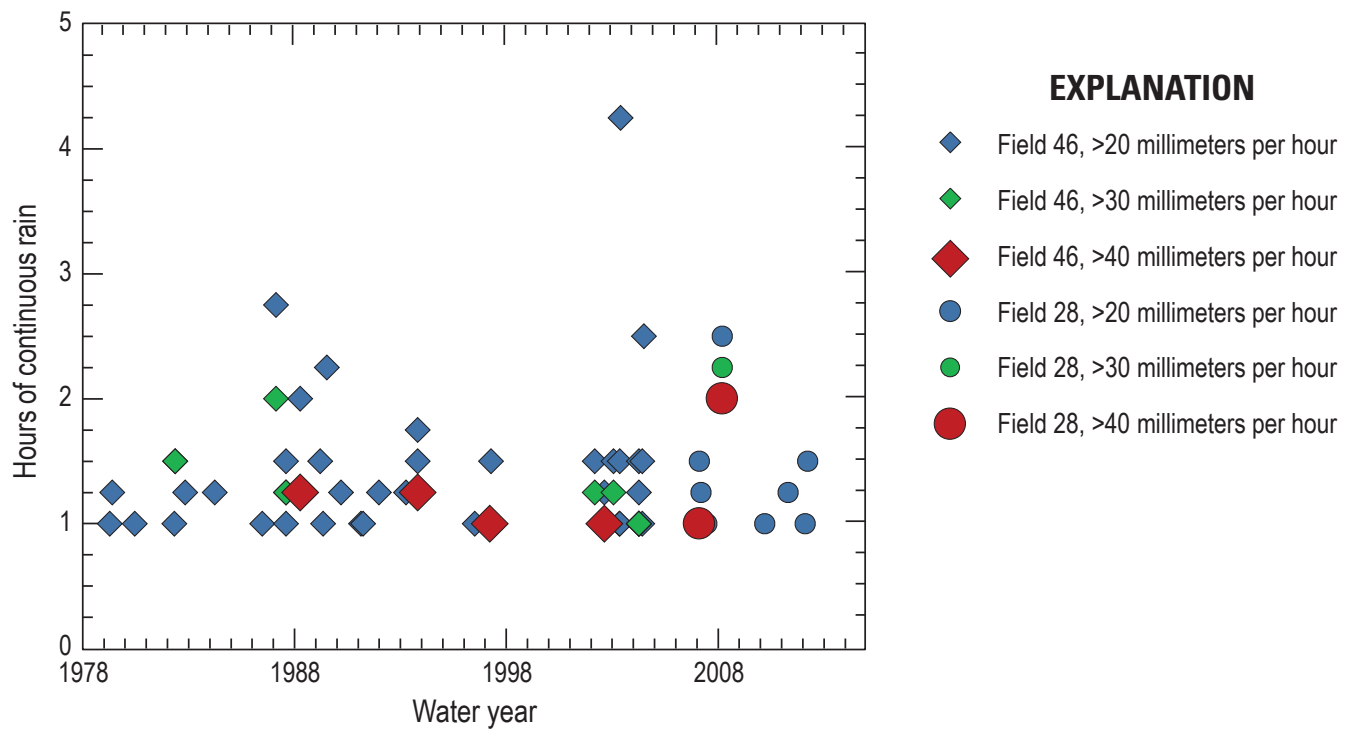

Figure 26. Plot showing occurrence of largest storms in West Maui uplands since 1978. These storms are mostly cyclones associated with kona lows and upper-level troughs (see appendix tables 1.7, 1.8 for source data). Symbols represent hours $(>1)$ of rainfall at rates greater than 20,30 , and 40 millimeters per hour. The occurrence of these most intense, continuous rainfalls has not varied systematically over this period, even as the total hours of intense rainfall and annual rainfall totals have declined. The red dot in 2008 is the December 5, 2007, calendar year storm-the event with the most intense sustained rainfall on record. These largest storms likely represent the population of rainfall events most likely to result in steepland erosion and runoff.

December 5, 2007, storm was the most intense storm during the $\sim 30$-year record of these gages. During that storm, it rained for $\sim 2$ hours at rates greater than $40 \mathrm{~mm} / \mathrm{hr}$ (table 1.7), well above the threshold for plume generation, and probably at intensities that generated runoff from some agricultural fields. These largest storms did not occur between 1978 and 1988 or between 2007 and 2014. The storms capable of generating widespread runoff from agricultural fields are decadal events in these records.

Figure 27 illustrates the structure of rainfall intensity for the largest historic storms in West Maui. As rainfall intensity increases, there is an exponential decline in the number of hours with rainfall at or above a given value. Most storms have an intercept of $\sim 4$ and slope values of $\sim 0.05$ (see equation at lower right of fig. 27A). The similarity of the curves at this scale suggests that these storms came from a similar population. But meteorological analysis reported in appendix tables 1.5-1.8 shows that cyclones (upper-level troughs and kona lows) and cut-off lows may trigger these intense rains. For instance, the storm of May 5, 1987, was an upper-level trough, exceptional for its long-duration and high-intensity rainfall. The storm of December 5, 2007, was a kona low, the most intense storm of record, with a rainfall intensity greater than 40 $\mathrm{mm} / \mathrm{hr}$ and lasting for more than one hour. All three synoptic storm types (upper-level trough, kona low, and cut-off low) generate rainfall intensities sufficient to cause erosion.

So what is the historic recurrence interval for rainfalls that generate plumes? Table 5 and figure 28 report the average return interval for historic 1- and 2-hour rainfall intensities. Two-hour intensities above $10 \mathrm{~mm} / \mathrm{hr}$ happened about three times a year in the northern wet side (Field 46) and about once a year to the south at Lahaina. These values are slightly lower than the 4-5 times/year recurrence interval suggested by the recent record between 2014 and 2016, shown in figure 18. This suggests that West Maui can expect rainfalls that generate plumes to occur between 3 and 5 times a year, depending on vagaries of storm generation.

For similar recurrence intervals, it rains twice as hard in the north (Field 46) as it does in the south (Lahaina). This difference diminishes for 2-hour intensities. Our sample locations at sandy agricultural fields would, therefore, experience brief runoff from greater than $50 \mathrm{~mm} / \mathrm{hr}$ rainfall intensities about once a decade near Lahaina, but every 1.5 years at Field 46. Sustained runoff from agricultural fields for more than 1 hour would be very rare because intensities greater than $50 \mathrm{~mm} / \mathrm{hr}$ sustained for two hours are not present in the over two-decade-long records. Because rainfall totals have decreased through time, these recurrence intervals may now be longer. As of July 2014, machine disking marks remained in the fields from the last agricultural treatment around 2012, indicating that storms greater than $50 \mathrm{~mm} / \mathrm{hr}$ sustained for two hours have not occurred since then.

\section{Geomorphic Process Map}

The geomorphic process map shows the current distribution of geomorphic processes in West Maui watersheds, with figure 29 showing the distribution of processes by area. Uplands are characterized by rockfall (for example, fig. 4D) 


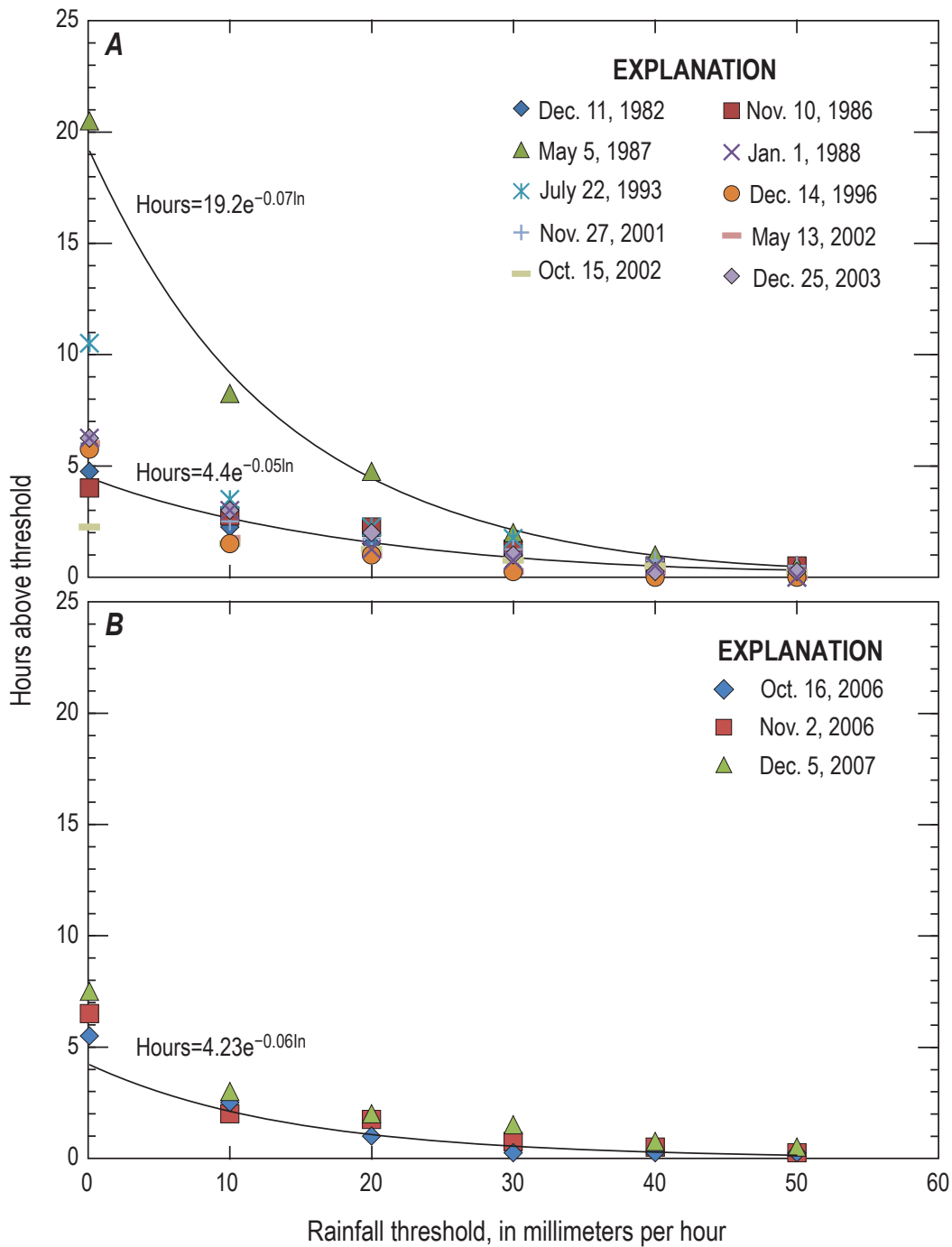

Figure 27. Plots showing the number of hours of rainfall above a given intensity for the larger storms over the record of Field $46(A)$ and Puu Kolii (B). Storm of May 1987 was one of the longest storms on record, although not the most intense, with over 5 hours of rainfall at intensities greater than 20 millimeters per hour ( $\mathrm{mm} / \mathrm{hr}$ ). The intensity structure of the remaining storms at Field 46 and Puu Kolii appear similar, as evidenced by nearly equal intercept $(4.2,4.4)$ and similar slopes $(-0.05$ to -0.06$)$. Most of these storms bring two or fewer hours of heavy rainfalls above $20 \mathrm{~mm} / \mathrm{hr}$ and have a characteristic curve, except for May 5, 1987, and July 22, 1993, which had long periods of lighter rain.

Table 5. Recurrence intervals for exceedance rainfalls at Field 46 and Lahaina. See figure 9 for data locations.

[mm/hr, millimeters per hour]

\begin{tabular}{cccccc}
\hline & \multicolumn{2}{c}{ Field 46 } & & \multicolumn{2}{c}{ Lahaina } \\
\cline { 2 - 3 } \cline { 5 - 6 } $\begin{array}{c}\text { Rainfall intensity } \\
\text { exceeds } \\
(\mathbf{m m} / \mathbf{h r})\end{array}$ & $\begin{array}{c}\text { 1-hour } \\
\text { recurrence } \\
\text { (years) }\end{array}$ & $\begin{array}{c}\text { 2-hour } \\
\text { recurrence } \\
\text { (years) }\end{array}$ & & $\begin{array}{c}\text { 1-hour } \\
\text { recurrence } \\
\text { (years) }\end{array}$ & $\begin{array}{c}\text { 2-hour } \\
\text { recurrence } \\
\text { (years) }\end{array}$ \\
\hline 20 & 0.2 & 1.6 & & 0.6 & 2.7 \\
30 & 0.4 & 3.9 & & 3.5 & 24.0 \\
40 & 0.8 & $>27.6$ & & 6.0 & $>24.0$ \\
50 & 1.5 & $>27.6$ & & 12.0 & $>24.0$ \\
60 & 3.1 & $>27.6$ & & $>24.0$ & $>24.0$ \\
70 & 4.6 & $>27.6$ & & $>24.0$ & $>24.0$ \\
\hline
\end{tabular}




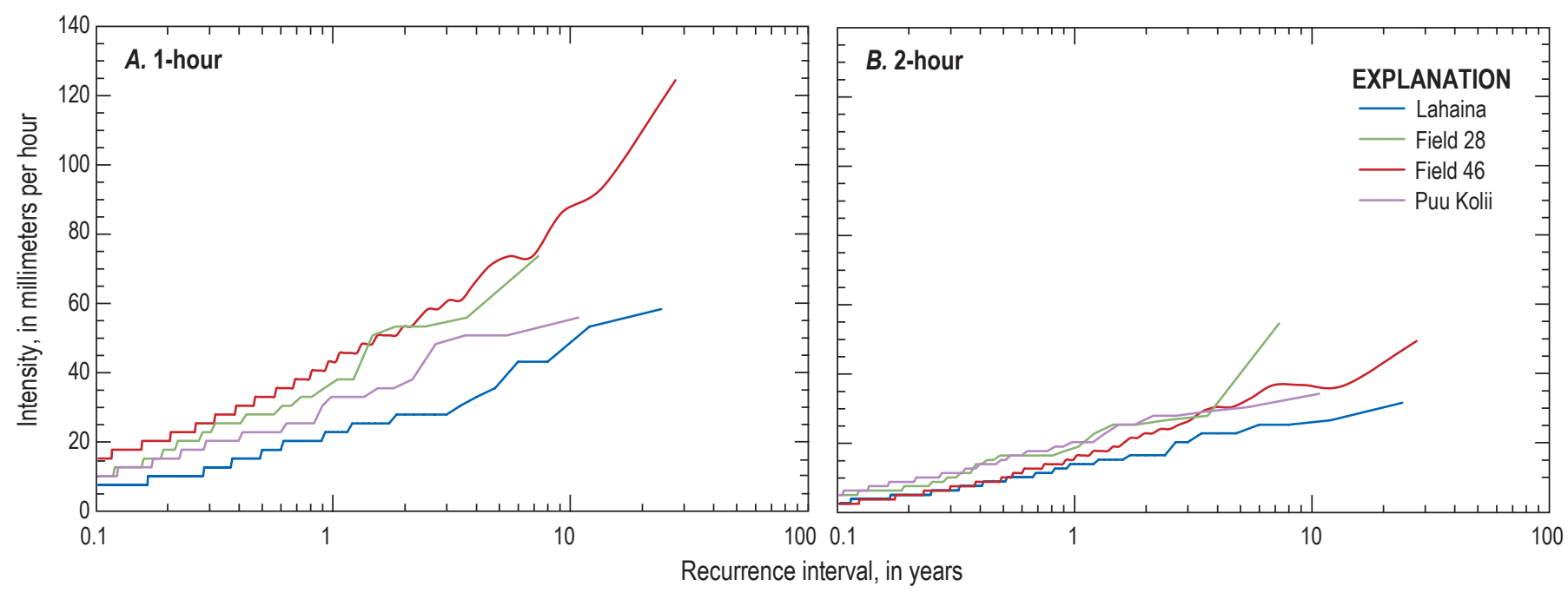

Figure 28. Plots of recurrence intervals for 1-hour rainfall intensities $(A)$ and 2-hour rainfall intensities $(B)$ in West Maui. See figure 9 and table 5 for locations and values, respectively, and text for details and limitations of records. Rainfall intensity for a given recurrence interval is roughly twice as high in the north (Field 46) as it is in the south (Lahaina). This difference diminishes for 2-hour intensities. Many of the sandy agricultural fields would experience runoff from greater than 50 millimeters per hour ( $\mathrm{mm} / \mathrm{hour}$ ) rainfalls only about once a decade in the Lahaina area and every 1.5 years at Field 46. Because rainfall intensities have decreased through time, the current recurrence intervals could be much longer, as evidenced by the machine disking marks that remain in the fields from the last treatment over 3 years before the photo. Runoff from agricultural fields for over 1 hour would be very rare because 2-hour intensities greater than $50 \mathrm{~mm} / \mathrm{hr}$ are not present in the over 2-decade-long records.

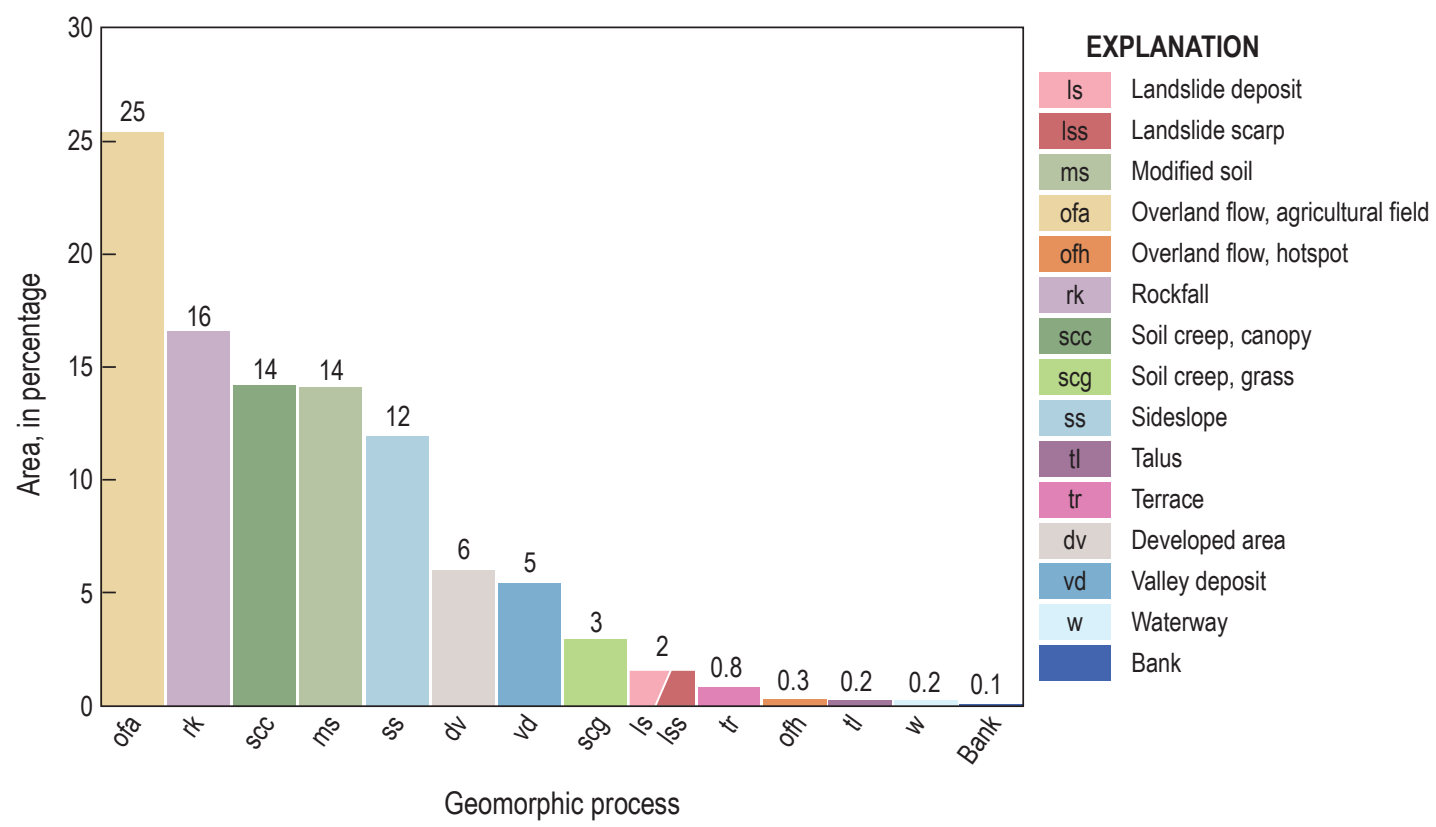

Figure 29. Area of each geomorphic process as a percentage of total map area (see accompanying map plate).

and soil creep (for example, figure $4 A, B$ ) occurring in forested areas with a largely intact canopy. Processes that create coarse sediment, such as rockfalls and landslides, occupy one-fifth to one-third of larger watersheds like Honolua, Honokahua, Kahana, Honokōwai, and Wahikuli (table 6). Lava-flow edges crop out as continuous bands along many steep valley walls (fig. 4D), illustrating the lack of soil. Flutes as wide as 10 to $100 \mathrm{~m}$ cut some valley walls (fig. 4D), consistent with episodic scour by debris flows and rockfall. A few talus deposits are sufficiently large to appear in both DigitalGlobe imagery and 10-m topography; most are too small to map. Large ( $>100$-m-wide) bedrock landslides cut into low-relief surfaces of some watersheds. In Honolua and Honokahua watersheds, the landslides are concentrated upstream of 


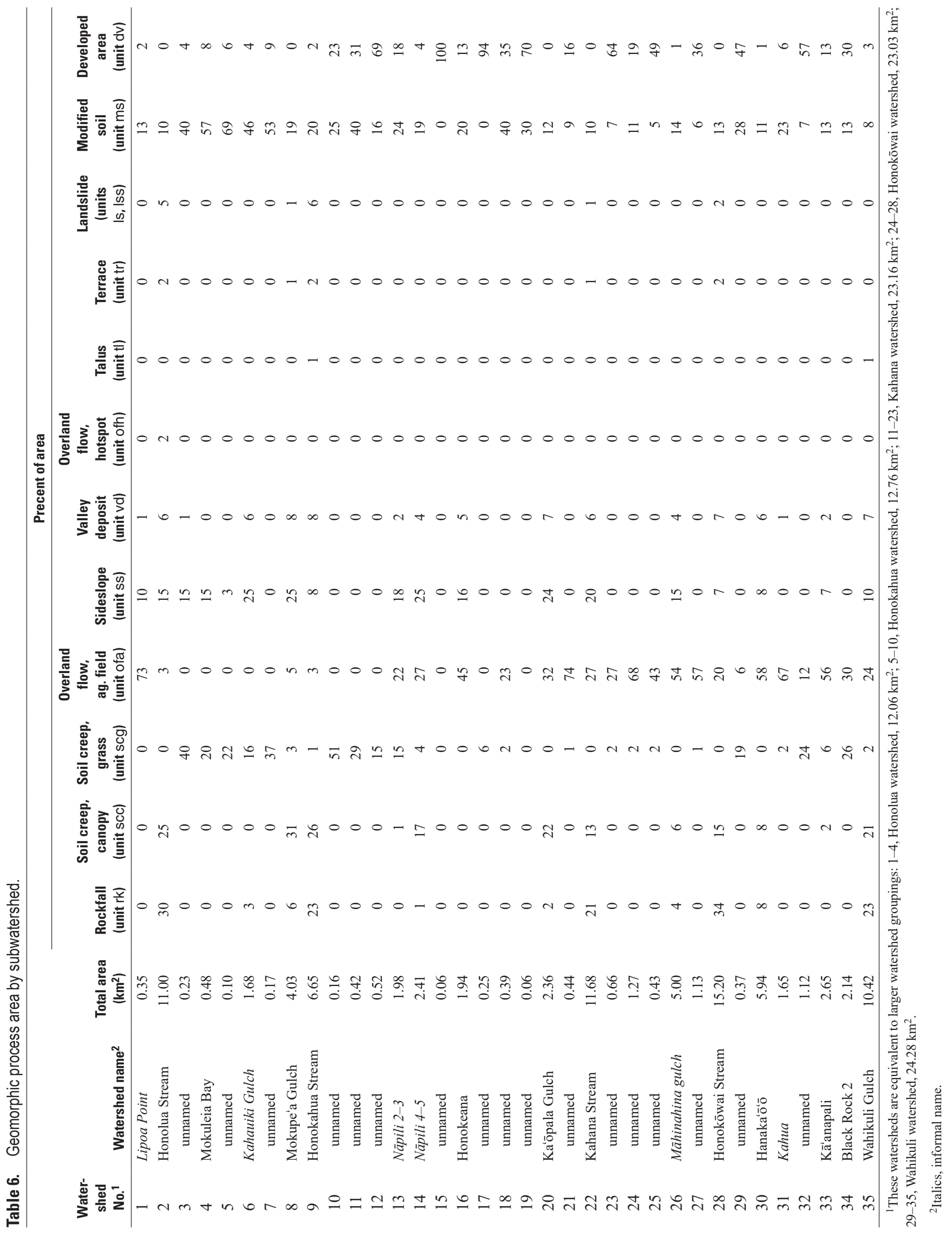


lineaments that may be the surface expression of dikes. Large (>3 m relief) debris-flow and fluvial terraces downstream of the landslides are consistent with an episodic release of coarse sediment that aggraded the valley bed, followed by incision. In the headwaters of Honokōwai Stream, we observed similar terraces composed of unsorted sediment lacking imbrication, consistent with deposition by debris flows (for example, fig. $7 B$ ). Along with smaller fluvial, debris-flow, and historic terraces, gravel and coarser grains arranged in pool-riffle, plane-bed, step-pool, or cascade bedforms (fig. 7A,C) make up the valley-deposits unit (vd). Our sparse, opportunistic measurements of hydraulic geometry and grain size scale with drainage area (fig. 30) at rates that are similar to streams elsewhere (for example, Dunne and Leopold, 1978).

Soil creep in low-relief, canopied areas occupies approximately one-fourth to one-sixth of larger watershed areas (table 6). Soil creep in grasslands occupies large portions of some of the smaller watersheds in table 6 , particularly where these small watersheds coincide with golf courses. Former agricultural fields (fig. 10B) are subject to Horton overland flow and occupy one-fifth to one-half of the larger southern watersheds (for example, Kahana, Māhinahina, Honokōwai, and Wahikuli). Northern watersheds like Honolua have a much smaller percentage of agricultural fields ( 3 percent). Current vegetation in these fields varies from full shrub cover to exposed soil.

Sideslope deposits of legacy agricultural soils occupy one-tenth (Wahikuli subwatershed) to one-fourth (Ka'oppala subwatershed) of the area of larger watersheds. These deposits are important because they represent a potential continuing source of increased sediment supply. A number of coalesced, shallow landslides with subsequent overland flow perpetuate the barren area in the lower Honolua watershed (fig. 5E).

\section{Hydraulic Geometry and Extent and Rate of Bank Erosion}

Bank erosion of historic fill terraces (fig. 31) in West Maui watersheds is widespread and rapid. Figure 32 shows the distribution of surveyed historic fill terraces (orange lines), and tables 7 and 8 summarize walking surveys of four watersheds, where fine-grained fill terraces form $\sim 40$ percent of the total bank length as projected onto the NHD. These deposits have a mean thickness of $85 \mathrm{~cm}$ and a median of $75 \mathrm{~cm}$ (fig. 33A). They are predominately fine grained by visual estimation (fig. $33 B$ ). The average sample from monitoring sites (table 4; figs. 22, 23) is a sand or silt loam, with a median grain size of $0.04 \mathrm{~mm}$ and a composition of 47 percent silt, 45 percent sand, and 8 percent clay by volume. Fill-terrace deposits have three times more silt and one-fifth the median grain size of airfall from agricultural fields. Rapid erosion of fill-terrace deposits would shed high concentrations of silts and fine sands into stream waters.

Monitoring over 2015-2016 shows that median bankerosion rates of fill terraces range from 4.6 to $24.1 \mathrm{~mm} / \mathrm{yr}$

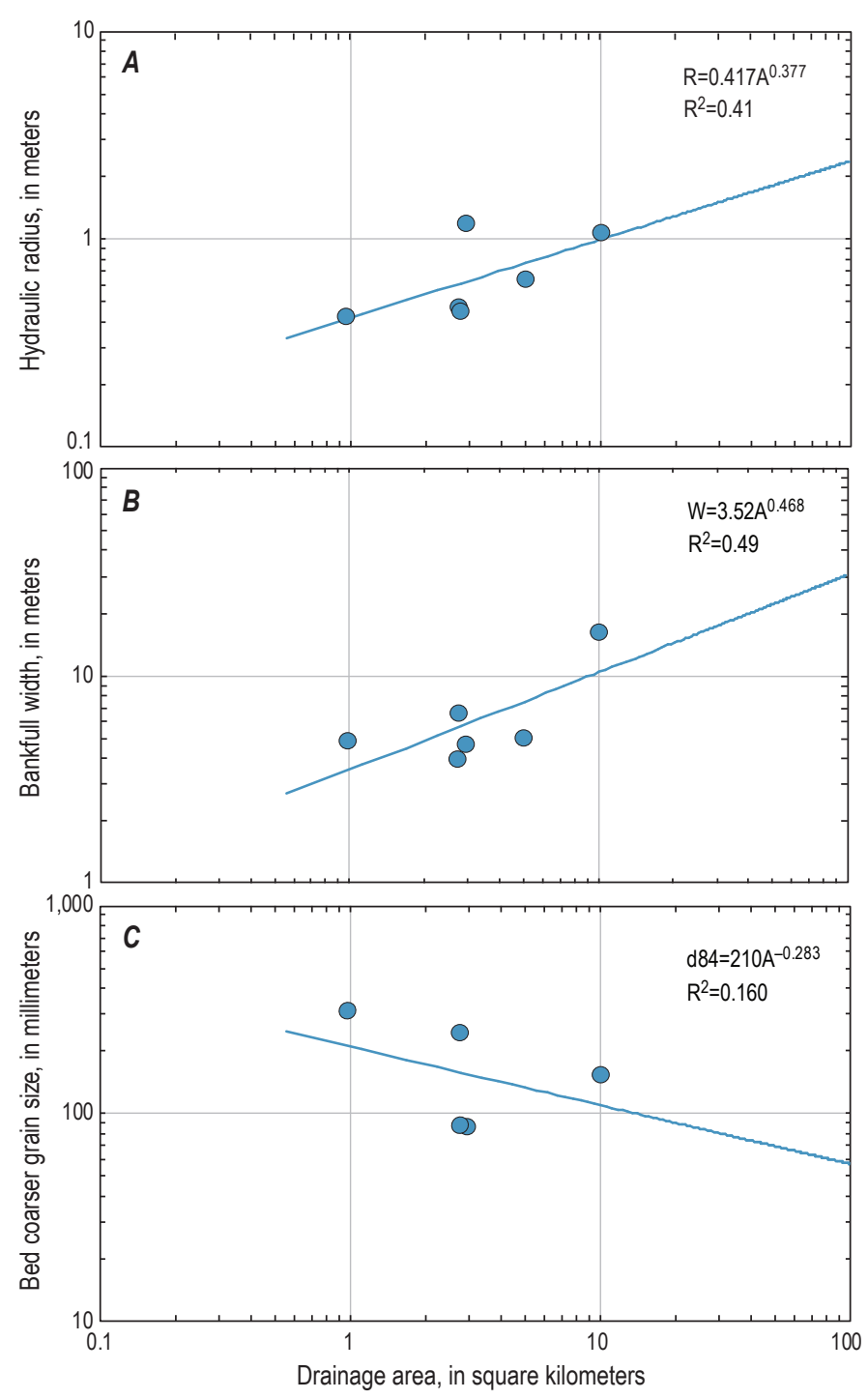

Figure 30. Hydraulic geometry and grain size for selected channels in West Maui, including erosion-pin cross-section locations. See table 7 for source data. Channel dimensions of $A$, hydraulic radius $\mathrm{R}$, and $B$, bankfull width $\mathrm{W}$, grow downstream with drainage area $A$ at rates that are comparable to channels elsewhere. $\ln C$, the coarser particles that characterize grain resistance to flow ( $d 84$, or 84 percent of grains are finer) decrease as drainage area increases. We use the hydraulic geometry to estimate reach-averaged shear stresses for bankfull flow in West Maui valleys, with the notion that this value might be a very crude proxy for bank erosion rates.

(table 7; figs. 34, 35). The three wet sites (Honolua Stream and Pāpua Gulch) have systematically higher rates compared to the dry site of Māhinahina gulch (fig. 34). When combined, rates from the three wet sites have a median lowering rate of 14 millimeters per year ( $\mathrm{mm} / \mathrm{yr})$ and approximate a lognormal distribution of lowering rates (table 7; fig. 35). The Interquartile Range (IQR) for all four sites is 5.2 to 18.0 $\mathrm{mm} / \mathrm{yr}$, a range of values we use to characterize the range of likely bank-erosion rates across all of West Maui's streams. Table 7 also shows estimates for reach-averaged shear stress 
A. Pāpua Gulch, Pāpua 1

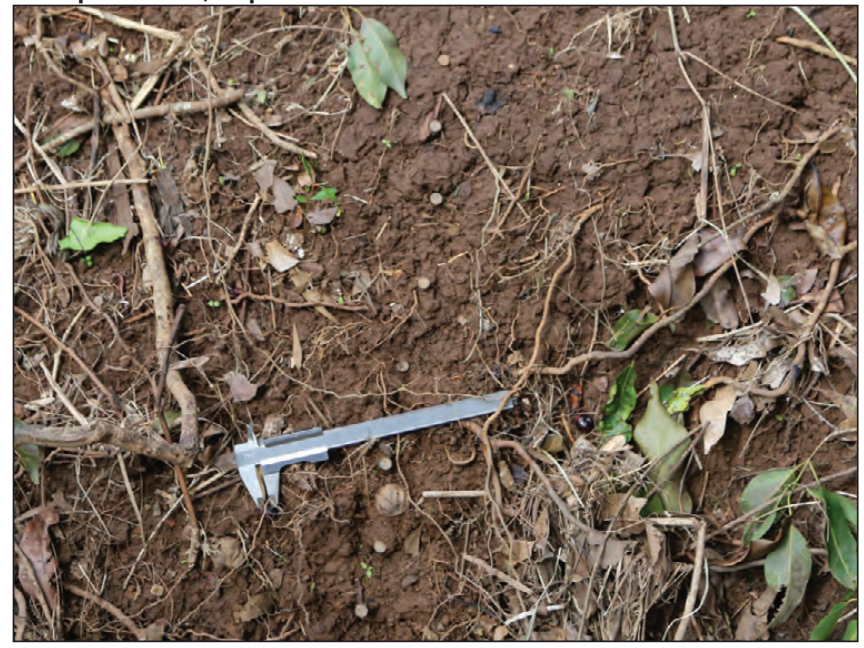

C. Honolua Stream, Honolua

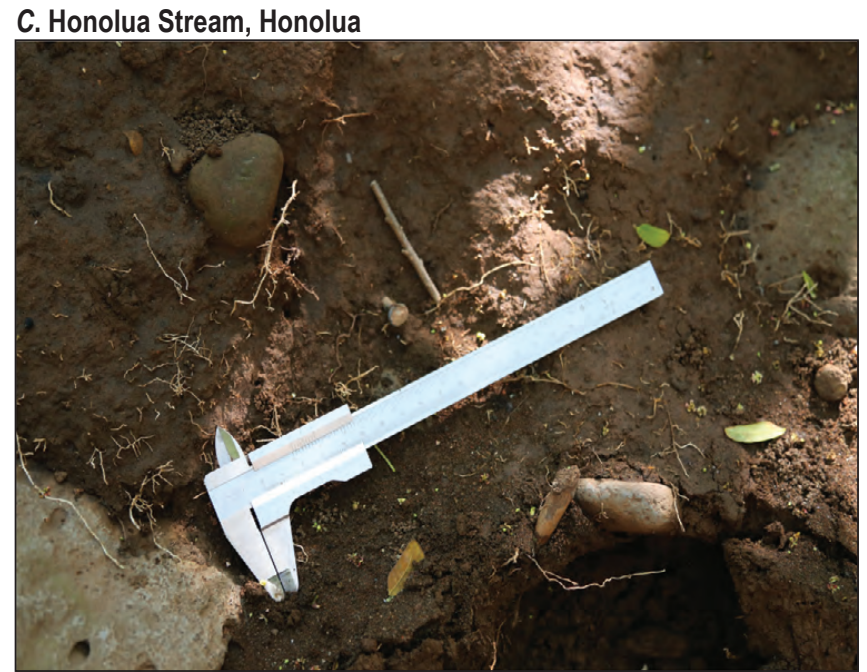

B. Pāpua Gulch, Pāpua 2

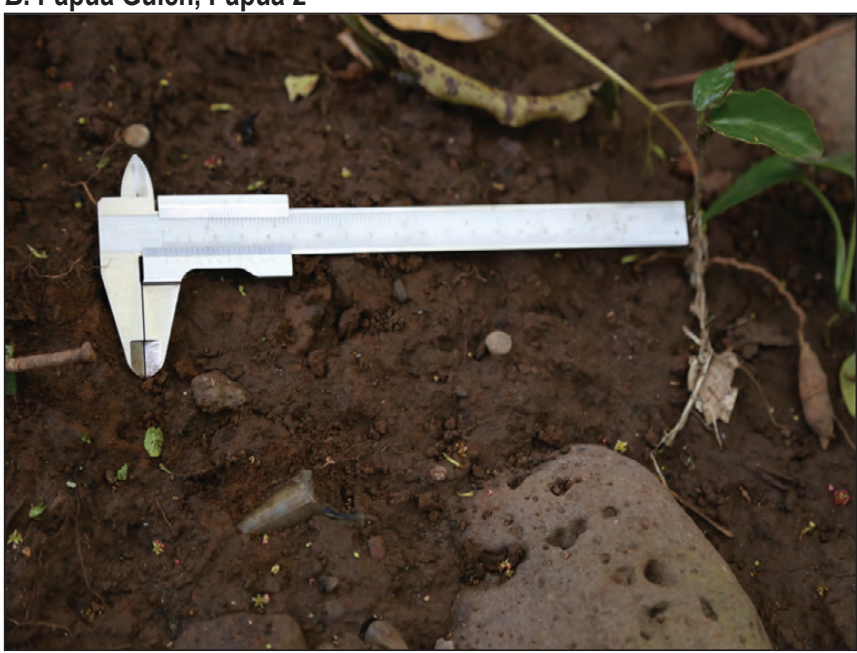

D. Māhinahina gulch, Māhinahina

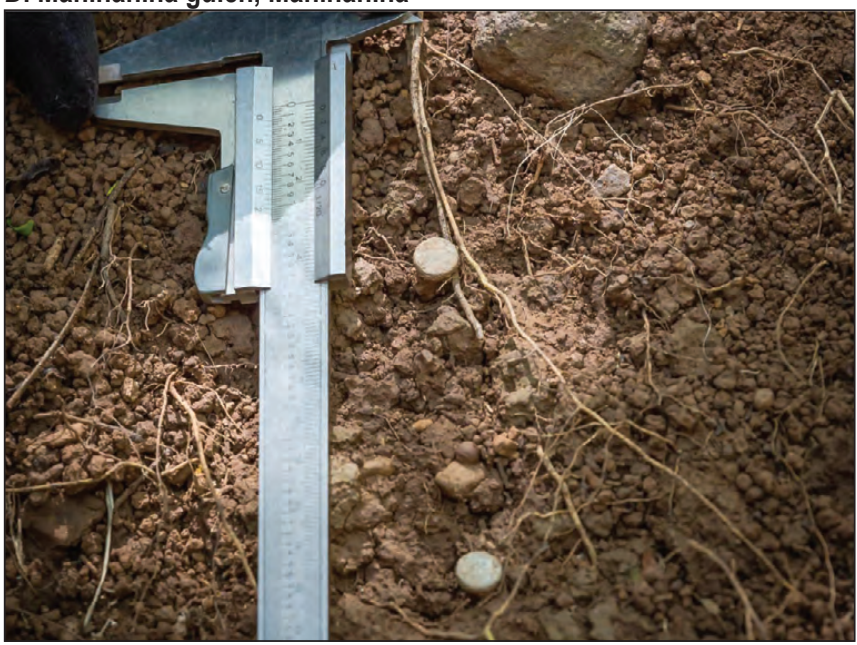

Figure 31. Bank erosion of historic fill terraces, West Maui. $A$, Pāpua 1 detail; $B$, Pāpua 2 detail; $C$, Honolua; $D$, Māhinahina detail. Exposed nails and roots show surface lowering by bank erosion over approximately 1 year of observation (15-centimeter-long calipers for scale).

from the most recent high-flow event. There is no obvious relation between these stresses and resultant lowering rates, at least at this event scale. Plotting hydraulic geometry for the monitoring sites and a few additional sites chosen opportunistically allows us to generalize reach-average shear stresses across the network, as a potential proxy for bankerosion rate.

\section{Estimates of Bank-Material Resistance}

Figure 36 shows the decline in water clarity (transmission) as increasing jet pressures erode bank materials (table 8). We interpret these graphs to estimate (1) what water stresses initiate bank erosion and (2) which stresses would entrain most bank material. These curves indicate that this bank material has a distribution of effective-cohesion values rather than one narrow range. In table 8, we use 90 percent transmission as an estimate for initiation of bank erosion in substantial amounts and 25 percent transmission as an estimate for substantial removal of bank material near the jet. We always found a jet scour pit at the end of tests, indicating that the maximum jet stresses we applied were sufficient to erode intact bank material.

At 'Iao Stream, on the east side of Maui, low and high curves bracket a fine-sand airfall test result, which is shown for comparison in figure $36 \mathrm{~A}$. The matrix of bank materials at 'Īao Stream is exceedingly weak, and minor water stresses between 0.2 and 0.5 kiloPascal $(\mathrm{kPa})$ initiate bank erosion. Water stresses above $0.7 \mathrm{kPa}$ are capable of eroding all of the matrix material given sufficent time.

In West Maui, light transmission begins to decline at water stresses of $\sim 0.2-0.5 \mathrm{kPa}$ (fig. 36A) and decreases up to stresses of $5 \mathrm{kPa}$. Water stresses above $2.5 \mathrm{kPa}$ tend to cause rapid reductions in transmission values for most surfaces. Fluctuations in transmission values of 10 percent are superimposed on this trend. Cohesion values for initiation 


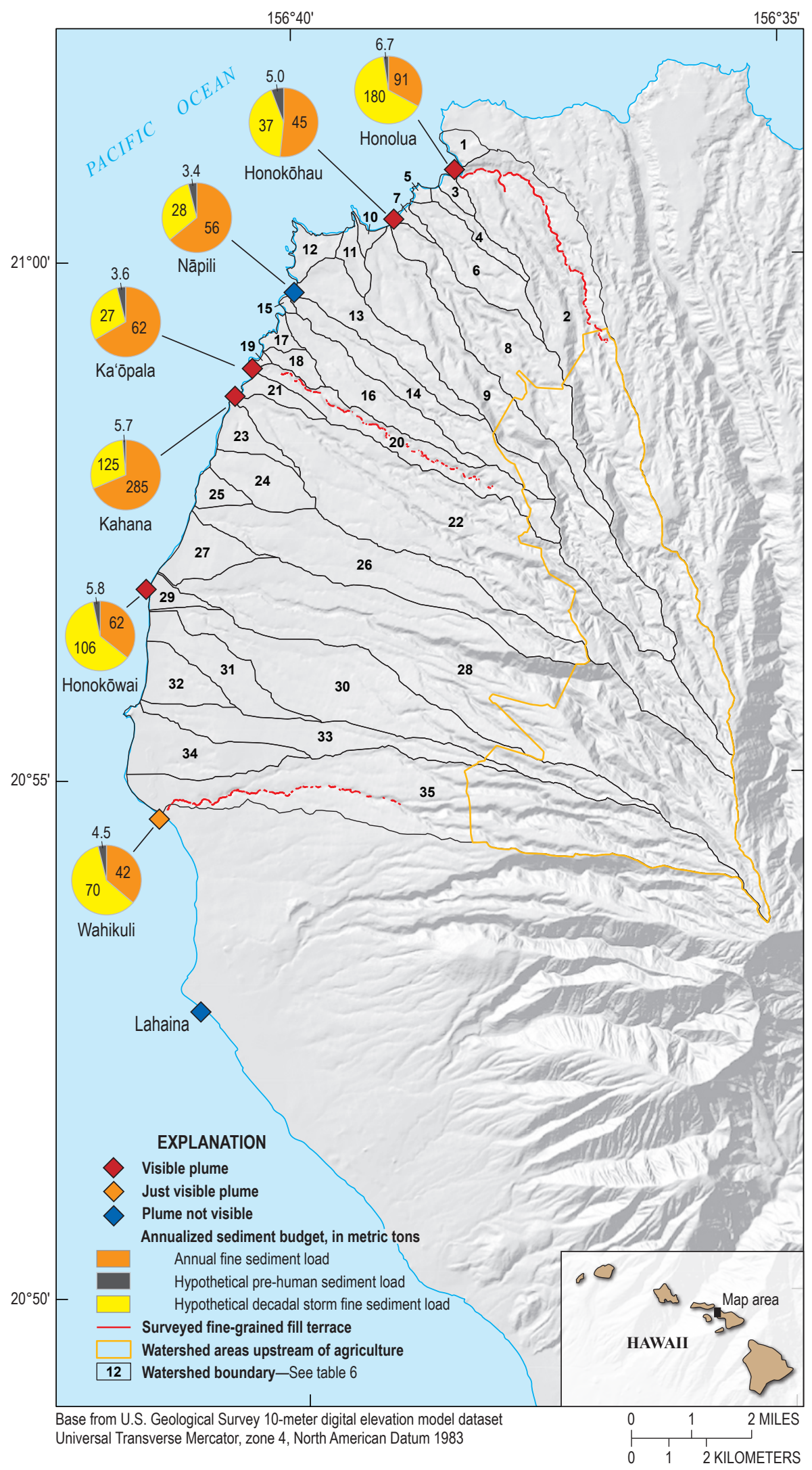

Figure 32. Map of West Maui showing watershed areas that are entirely upstream of agricultural influence (orange outline), locations of surveyed historic fill terraces (yellow lines), numbered watersheds of table 6, and pie charts showing the annualized sediment budget from the largest of the numbered watersheds, as reported in table 6. Historic fill terraces occur downstream of agricultural areas, which is what we expect if they are a result of agricultural practice. The pre-human sediment loading (gray pie slice) is often 10 times smaller than estimates of current loading in orange coastal plumes (diamond) observed by J.D. Stock on July 20, 2014, 13:00-18:00 HST. 

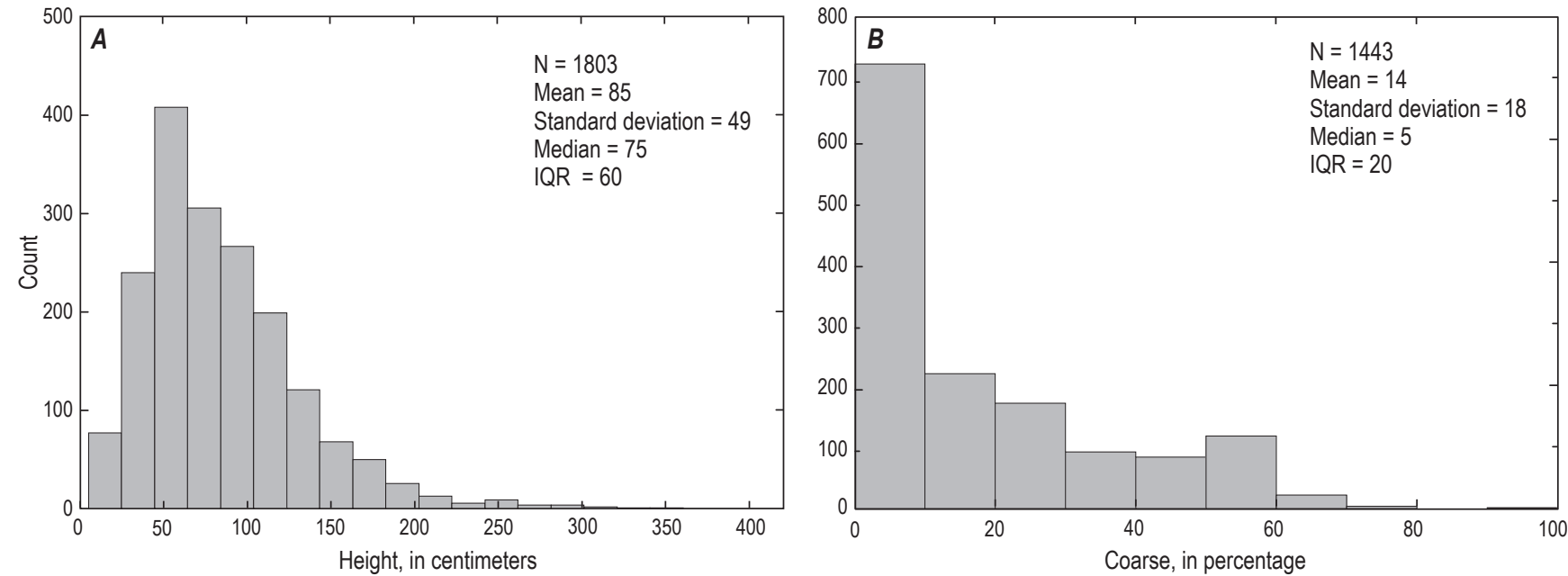

Figure 33. Distributions of $A$, measured heights ( \pm 5 centimeter [cm]), and $B$, visual estimates of the amount of coarse material (for example, larger than sand) in historic fill-terrace material of West Maui. We calculated the sediment flux from bank erosion in West Maui using the median values of height $(75 \mathrm{~cm})$ and coarse fraction (5 percent) calculated here. N, number of observations; IQR, Interquartile range.

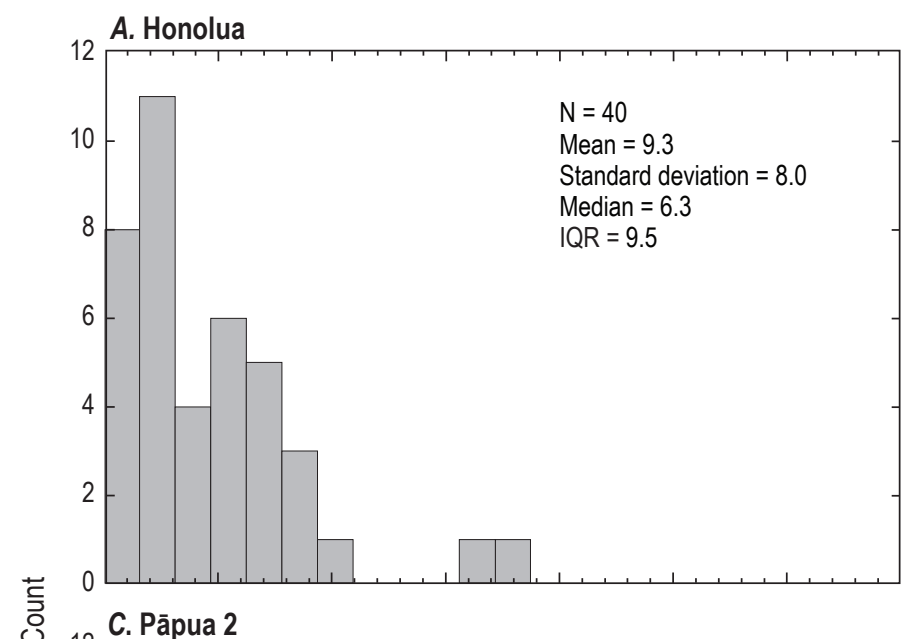

B. Pāpua 1

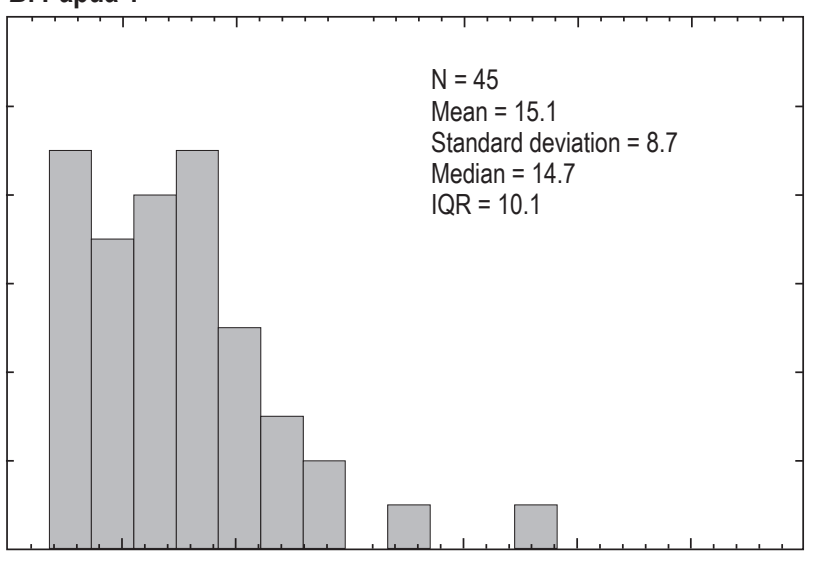

D. Māhinahina

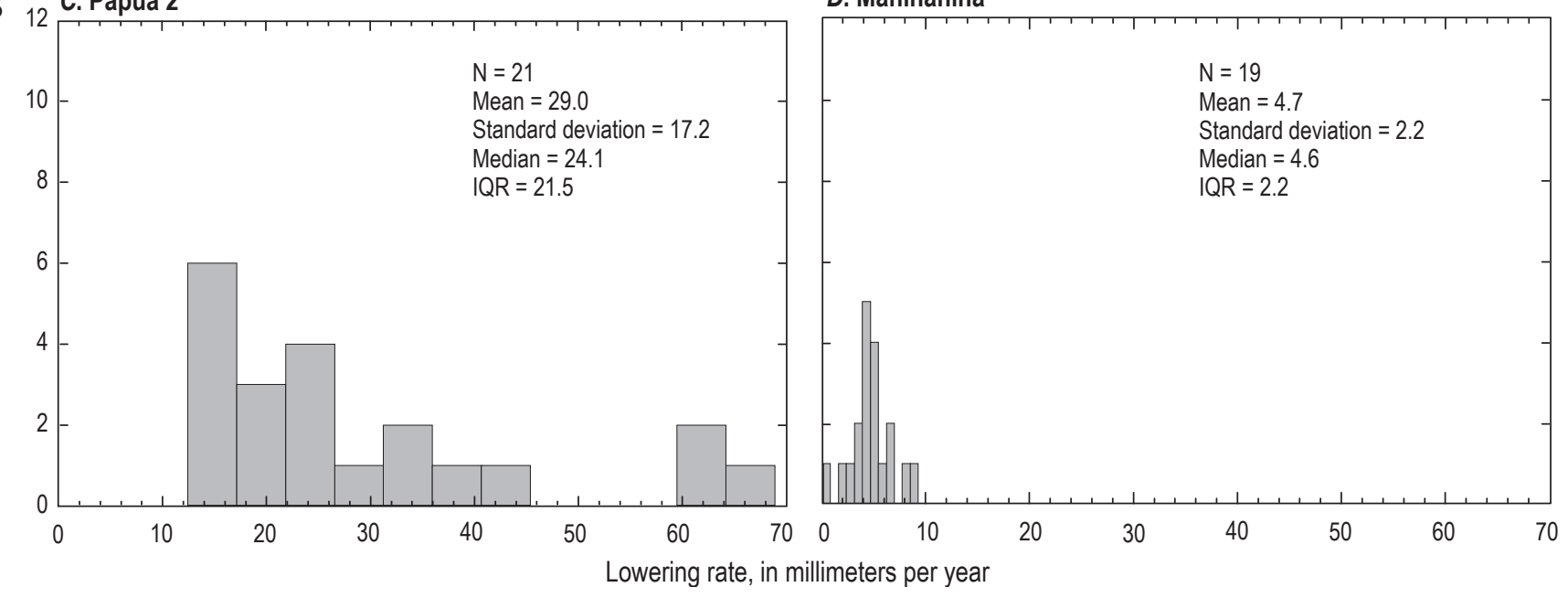

Figure 34. Lowering rates of historic fill terraces measured over a year at the locations shown in figure 9, West Maui, Hawaii. Lowering rates in the higher annual rainfall (wet side) channels of Honolua Stream (A), and its tributary Pāpua Gulch (B, Pāpua 1; C, Pāpua 2), are much higher (means of 9.5, 15.1 and 29.0 millimeters per year [mm/yr]) than those found at Māhinahina gulch $(D)$, an ephemeral channel (mean of $4.7 \mathrm{~mm} / \mathrm{yr}$ ). We use the Māhinahina site rate of $\sim 5 \mathrm{~mm} / \mathrm{yr}$ to characterize dry-side bank erosion values at Māhinahina gulch and southwards. $\mathrm{N}$, number of observations; IQR, Interquartile range. 


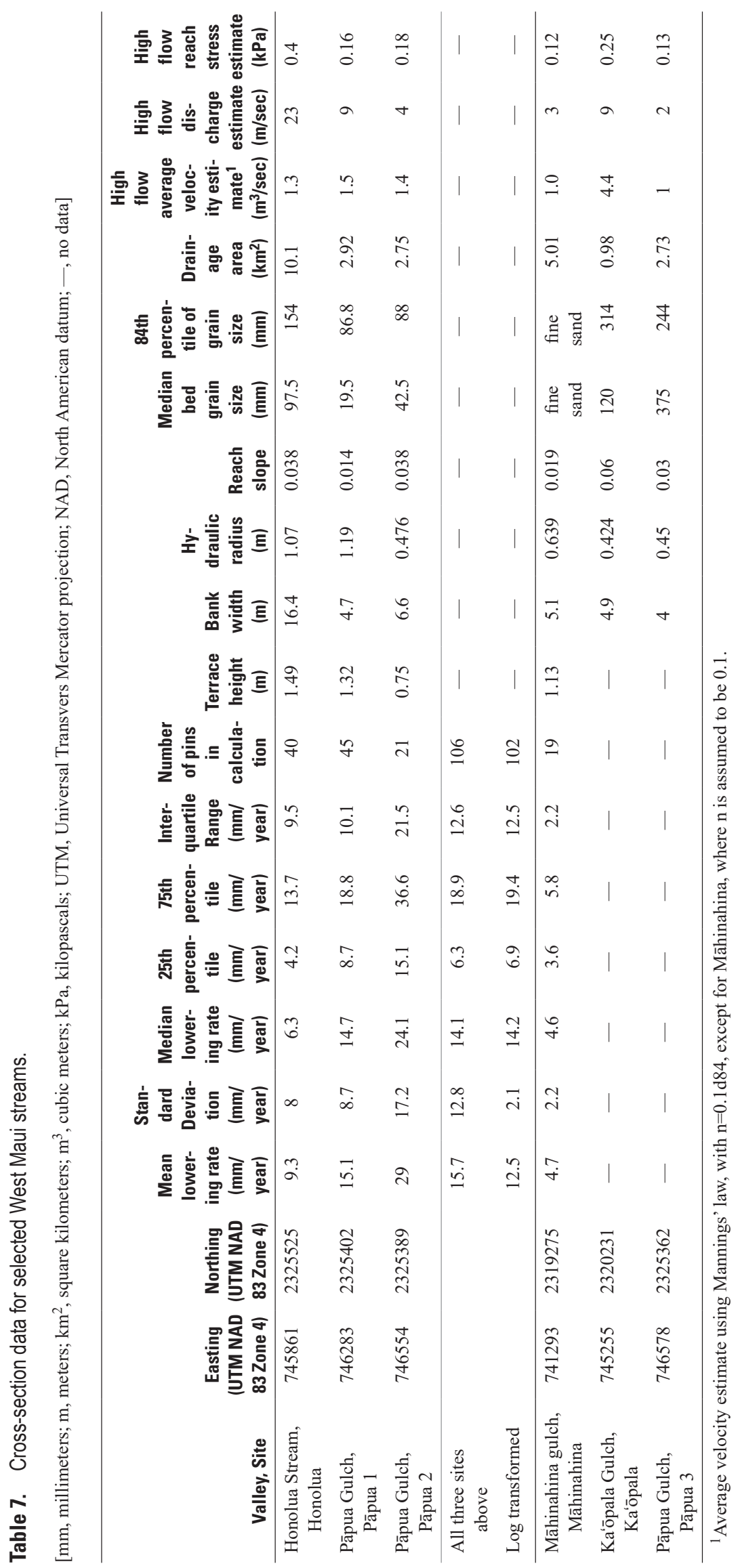



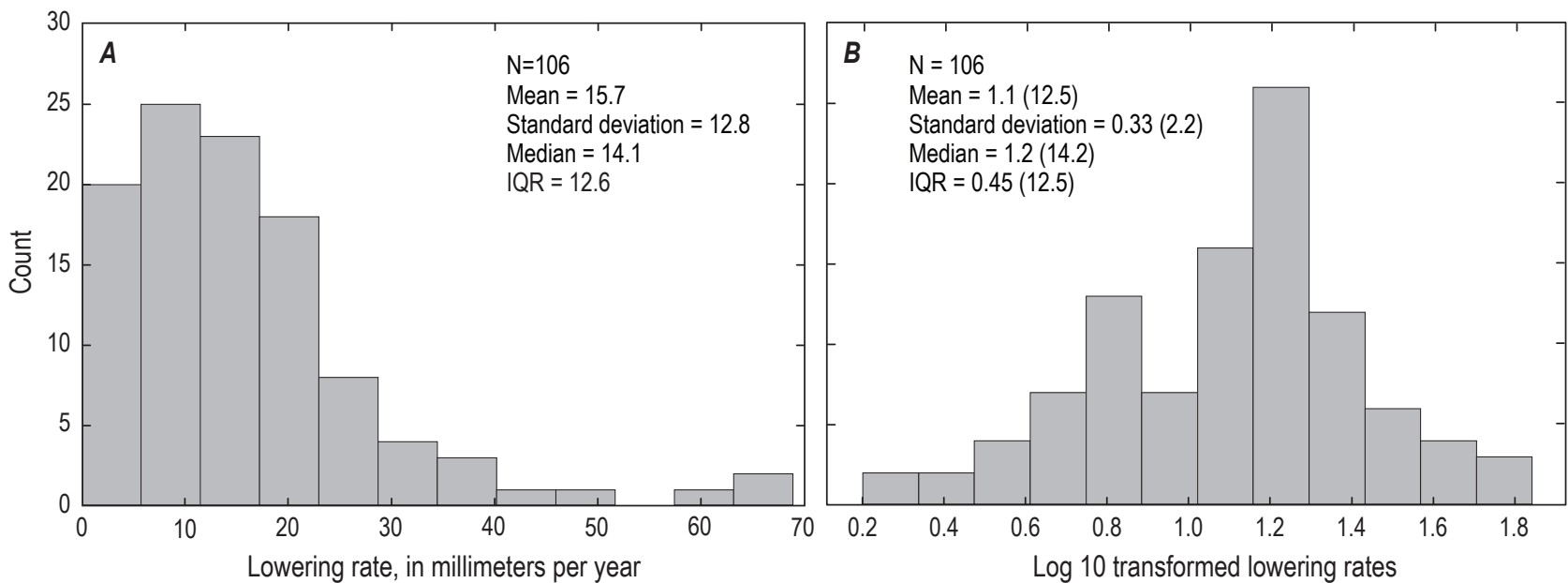

Figure 35. A, Bank lowering rates merged for the three higher-rainfall sites (wet side) in West Maui, and $B$, the log-transformed distribution. We apply the median of the merged wet-side lowering rates ( 14 millimeters/year) to represent bank erosion rates north of the Māhinahina site. The log-transformed distribution is skewed to lower values. Equivalent untransformed values are show in parentheses. N, number of observations; IQR, Interquartile range.
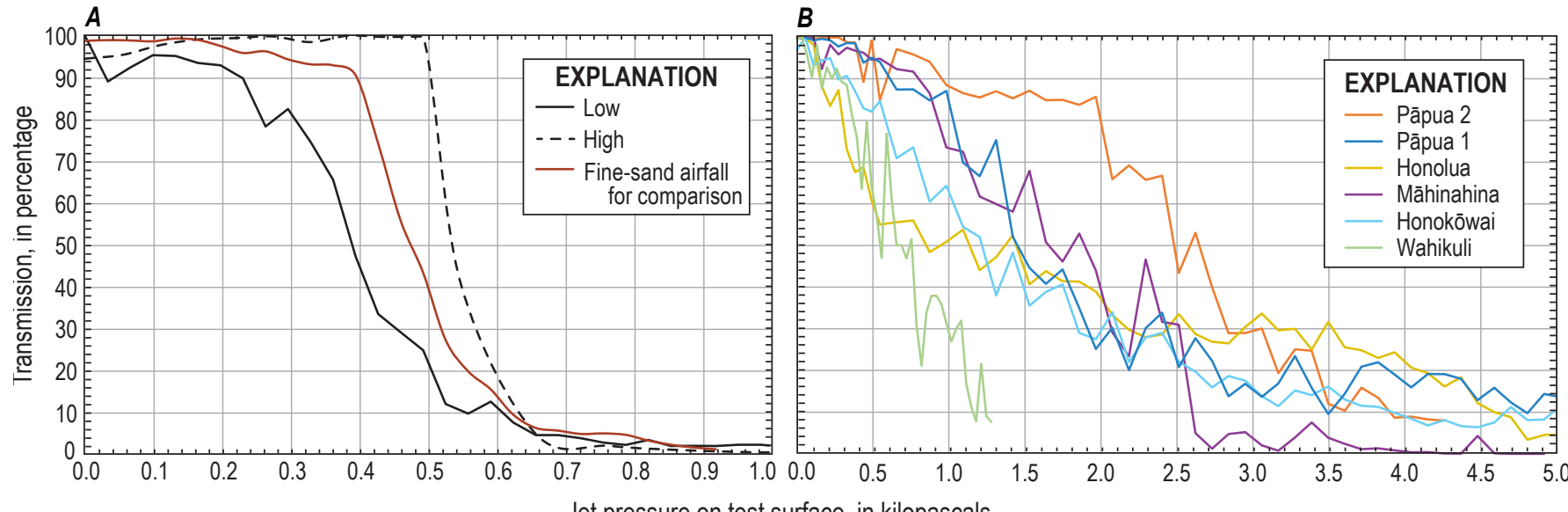

Figure 36. Plots showing the decline in water clarity (transmission) as increasing Partrac Cohesive Strength Meter (CSM) jet pressures erode bank materials. A, "Tao Stream, with low and high values for the same test area bracketing a fine-sand airfall test result shown for comparison. The matrix of bank materials at 'Tao Stream is exceedingly weak, and minor jet pressures between 0.2 and 0.5 kilopascal $(\mathrm{kPa})$ initiate bank erosion. $B$, Bank materials from West Maui's historic fill terraces. Higher clay and silt content of these materials makes them strong compared to 'Tao Stream, and it takes jet stresses above $1 \mathrm{kPa}$ to lower all transmission values below 10 percent. Locations (fig. 9) listed from northernmost site (Pāpua 2) to southernmost site (Wahikuli). There is no obvious geographic pattern in bank resistance; bank materials are all susceptible to erosion at jet pressures above $0.4 \mathrm{kPa}$, with major losses for all above $2.5 \mathrm{kPa}$. 
Table 8. Estimates of streambank material cohesion.

[UTM, Universal Transverse Mercator projection; NAD, North American Datum; mm, millimeters; PSI, pounds per square inch; kPa, kilopascals; -, no data]

\begin{tabular}{|c|c|c|c|c|c|c|c|c|c|c|c|c|c|}
\hline $\begin{array}{c}\text { Valley } \\
\text { (Island of Maui) }\end{array}$ & $\begin{array}{c}\text { Easting } \\
\text { (UTM NAD } \\
83 \text { Zone 4) }\end{array}$ & $\begin{array}{l}\text { Northing } \\
\text { (UTM NAD } \\
83 \text { Zone 4) }\end{array}$ & Material & $\begin{array}{c}\text { Median } \\
(\mathrm{mm})\end{array}$ & \multicolumn{2}{|c|}{ Cohesion at $\mathbf{9 0} \%$} & \multicolumn{2}{|c|}{ Cohesion at $75 \%$} & \multicolumn{2}{|c|}{ Cohesion at $\mathbf{5 0} \%$} & \multicolumn{2}{|c|}{ Cohesion at $25 \%$} & $\begin{array}{c}\text { Bankfull } \\
\text { shear stress } \\
(\mathrm{kPa})\end{array}$ \\
\hline 'T̄ao Stream & 760614 & 2313091 & $\begin{array}{l}\text { Debris flow } \\
\text { deposit } \\
\text { matrix }\end{array}$ & 0.04 & 0.08 & 0.5 & 0.08 & 0.5 & 0.08 & 0.5 & 0.10 & 0.7 & - \\
\hline 'T̄ao Stream & 760614 & 2313091 & $\begin{array}{l}\text { Debris flow } \\
\text { deposit } \\
\text { matrix }\end{array}$ & 0.04 & 0.03 & 0.2 & 0.05 & 0.3 & 0.06 & 0.4 & 0.07 & 0.5 & - \\
\hline $\begin{array}{r}\text { Wahikuli } \\
\text { Stream }\end{array}$ & 740379 & 2314253 & $\begin{array}{l}\text { Fine-grained } \\
\text { fill terrace }\end{array}$ & 0.04 & 0.04 & 0.3 & 0.09 & 0.6 & 0.11 & 0.8 & 0.16 & 1.1 & - \\
\hline $\begin{array}{l}\text { Honokōwai } \\
\text { Stream }\end{array}$ & 741084 & 2317995 & $\begin{array}{l}\text { Fine-grained } \\
\text { fill terrace }\end{array}$ & 0.03 & 0.06 & 0.4 & 0.10 & 0.7 & 0.17 & 1.2 & 0.36 & 2.5 & - \\
\hline $\begin{array}{l}\text { Māhinahina } \\
\text { gulch }\end{array}$ & 741293 & 2319275 & $\begin{array}{l}\text { Fine-grained } \\
\text { fill terrace }\end{array}$ & 0.05 & 0.17 & 1.2 & 0.29 & 2.0 & 0.38 & 2.6 & 0.38 & 2.6 & 0.12 \\
\hline Pāpua Gulch & 746554 & 2325389 & $\begin{array}{l}\text { Fine-grained } \\
\text { fill terrace } \\
\text { (Pāpua 2) }\end{array}$ & 0.07 & 0.14 & 1.0 & 0.30 & 2.1 & 0.30 & 2.1 & 0.49 & 3.4 & 0.18 \\
\hline $\begin{array}{l}\text { All West Maui } \\
\text { sites average }\end{array}$ & - & - & - & 0.04 & 0.09 & 0.61 & 0.17 & 1.18 & 0.24 & 1.62 & 0.39 & 2.68 & 0.22 \\
\hline
\end{tabular}

of bank erosion (90 percent transmission) at all West Maui historic fill terraces range from 0.2 to $1.2 \mathrm{kPa}$ (table 8), with no obvious geographic distribution. Their average value of $0.6 \mathrm{kPa}$ is an estimate for the regional value of bank cohesion at which erosion begins. The average value for the six West Maui fine-grained site cohesions at 25 percent transmission is $2.7 \mathrm{kPa}$. We use this value to characterize the regional cohesion of fine-grained fill terraces in West Maui, above which substantial erosion would occur. Table 7 shows that, at all of the erosion-pin sites, estimates of reach-averaged bankfull stresses approximate or exceed the stress values at 90 percent transmission, predicting that bankfull flows have the ability to erode bank materials. These values are calculated assuming steady uniform flow, and they likely underestimate actual stresses from convective accelerations and point loads from entrained sediment.

\section{Reconnaissance Sediment Budgets for West Maui Watersheds}

Annual bank erosion of historic fill terraces sheds large masses of fine sediment into West Maui's streams (table 9; fig. 37). This is a consequence of the fact that $\sim 40$ percent of the total bank length downstream of the forest boundary is eroding into historic fill terraces. Surveys show these terraces have a median thickness of $0.75 \mathrm{~m}$ and material that is roughly
95 percent fine sediment (sand, silt, and clay) with a bulk density of $1,300 \mathrm{~kg} / \mathrm{m}^{3}$ (table 7). To generalize bank-erosion rates from our four monitoring sites (Honolua, Pāpua 1, Pāpua 2, Māhinahina, see table 7 or fig. 9 ), we assign perennial and intermittent streams north of Māhinahina gulch a wet-bankerosion rate of $14 \mathrm{~mm} / \mathrm{yr}$ and Māhinahina gulch and ephemeral streams south of it a dry-erosion rate of $5 \mathrm{~mm} / \mathrm{yr}$. We use the upper ( $18.0 \mathrm{~mm} / \mathrm{yr})$ and lower $(5.2 \mathrm{~mm} / \mathrm{yr})$ IQR values to calculate a range of sediment loads due to the uncertainty in bank-erosion rates (table 7).

The annual load from bank erosion ranges from zero for watersheds without identified channels to a high of 285 metric tons/yr for Kahana Stream, which has the highest value of eroding bank length $(\sim 55 \mathrm{~km})$ in West Maui. The median annual load for watersheds with bank erosion is 45 metric tons/yr, with most values within the range of 25-62 metric tons/yr. For wet valleys, sediment loads may be $\sim 37-128$ percent of the proposed value, depending on the choice of low or high bank-erosion rate. For dry valleys, the equivalent range is $\sim 104-360$ percent, a much larger range introduced by high-end bank-erosion rates. We illustrate these annual sediment loads to the nearshore in figure 37 and, as a fractional component of prehistoric and decadal sediment loads, in figure 32. Kahana and Honolua watersheds dominate loading, with Napili, Ka'ōpala, and Honokōwai watersheds trailing. Sediment yields, the annual load divided by watershed 
Table 9. Sediment budget for bank erosion of historic fill terraces, West Maui.

[ $\mathrm{m}^{2}$, square meters; $\mathrm{kg} / \mathrm{m}^{3}$, kilograms per cubic meter; DPW, Maui Department of Public Works; $\mathrm{km}$, kilometers; $\mathrm{m}$, meters; mm/year, millimeters per year; NA, data collected, but not enough data to calculate a value; - , site has never been used to collect data (no reservoir)]

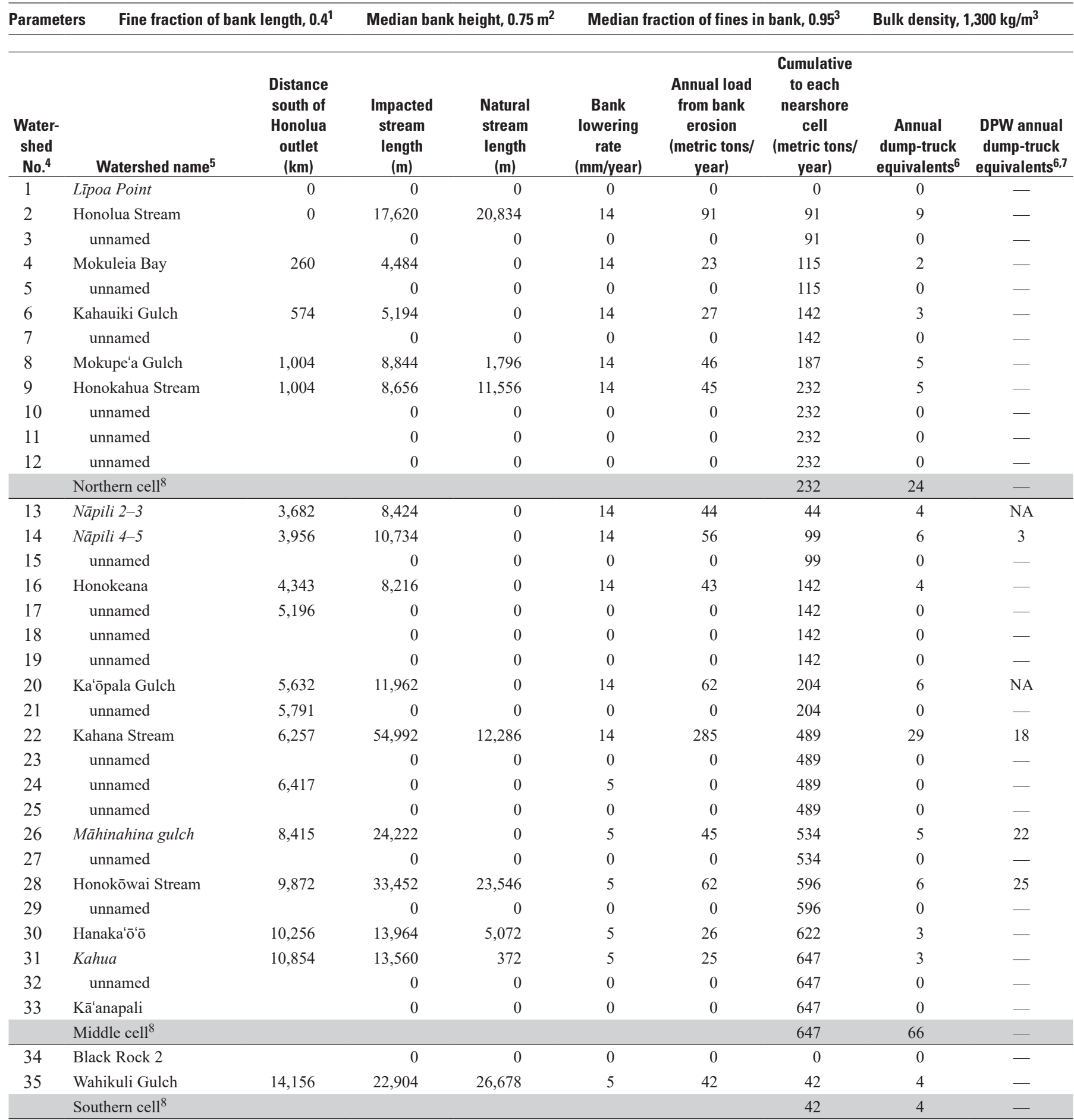

${ }^{1}$ Median value from survey of three streams in figure 23.

${ }^{2}$ Value from figure $27 \mathrm{~A}$.

${ }^{3}$ Value from figure $27 B$.

${ }^{4}$ These watersheds are equivalent to larger watershed groupings:

$1-4$, Honolua watershed, $12.06 \mathrm{~km}^{2} ; 5-10$, Honokahua watershed, $12.76 \mathrm{~km}^{2}$; 11-23, Kahana watershed, $23.16 \mathrm{~km}^{2} ; 24-28$, Honokōwai watershed, $23.03 \mathrm{~km}^{2}$ 29-35, Wahikuli watershed, $24.28 \mathrm{~km}^{2}$.
${ }^{5}$ Italic, informal name.

${ }^{6}$ Assumes a 7.6 cubic meter truck capacity of equivalent density.

${ }^{7}$ Provided by Eugene Tihada, Maui Department of Public Works, email of August 9, 2018.

${ }^{8}$ Along-shore sediment transport cells shown in fig. 39 (fig. 4 in Storlazzi and Field, 2008). 


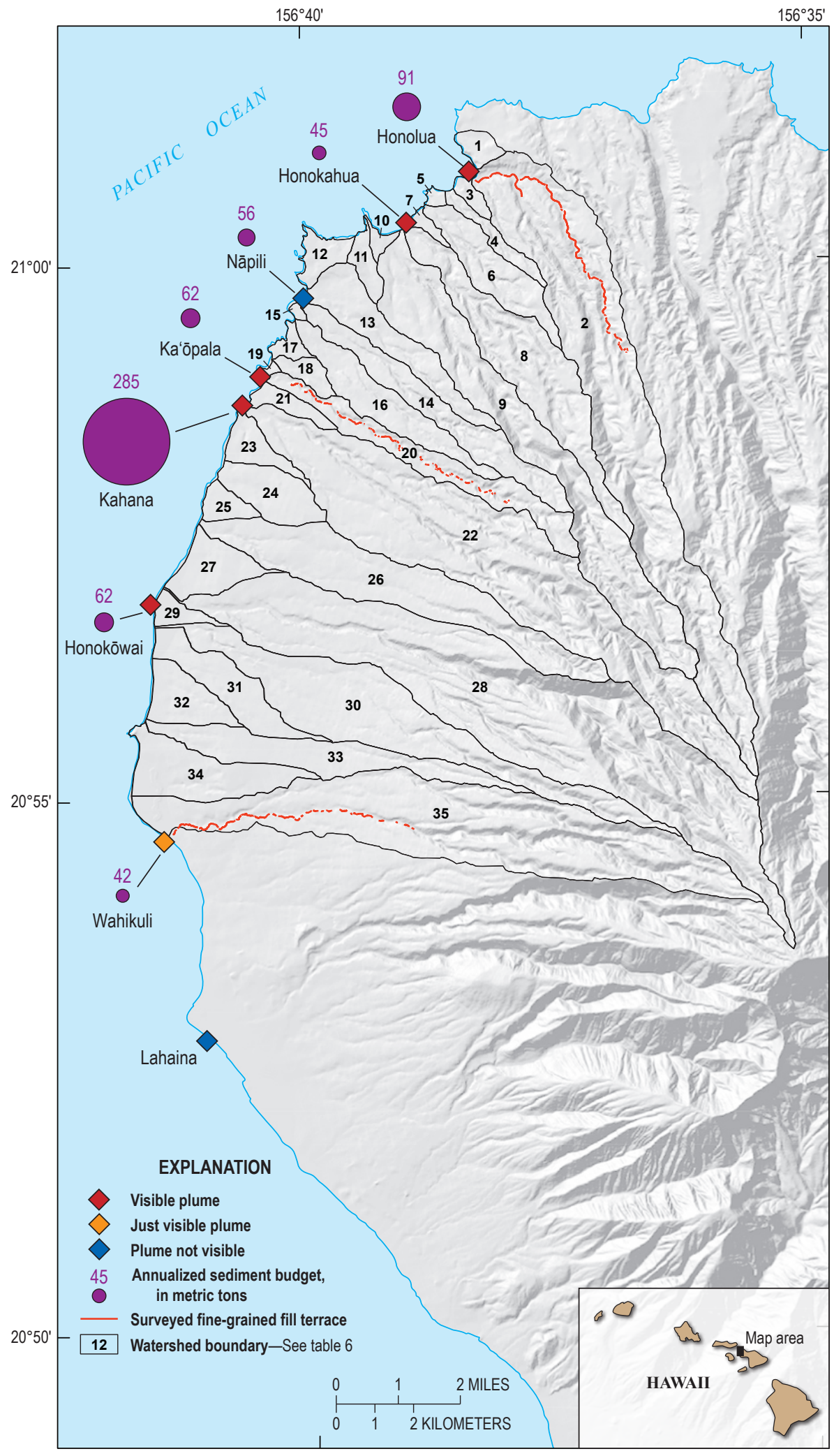

Figure 37. Illustration of the annual fine-sediment load to the nearshore from each watershed in West Maui, plotted as purple circles proportional to the metric tons reported in table 6 . The red and orange diamonds denote where nearshore sediment plumes were visible after the July 2014 storm. Kahana watershed produces $\sim 29$ dump-truck loads of sediment annually, 4-5 times more sediment than other watersheds because of its size and the length of eroding terraces. Kahana and Ka'ōpala watersheds have large sediment loads, and some of the highest sediment yields of the watersheds along the coast (tables 9, 10), which makes them prime targets for mitigation. area, vary from zero values to a high of 48 metric tons $/ \mathrm{km}^{2} / \mathrm{yr}$ (table 10). The 15 watersheds with non-zero values have a median annual sediment yield of 15 metric tons $/ \mathrm{km}^{2} / \mathrm{yr}$, with most of the larger watersheds between 9 and 26 metric tons/ $\mathrm{km}^{2} / \mathrm{yr}$. Ka'oppala has the highest sediment yield of the larger watersheds at 26 metric tons $/ \mathrm{km}^{2} / \mathrm{yr}$.
Maui County Department of Public Works (DPW) episodically removes sediment (both bed and suspended material) from retention basins below Honokōwai, Māhinahina, Kahana, Ka'ōpala, Nāpili 4-5, and Nāpili 2-3 watersheds. The last column of table 9 reports average values for the number of dump-truck loads removed from some of 
these basins in the 2009-2018 period. Volumes for Nāpili 2-3 and $\mathrm{Ka}^{\prime}$ ōpala watersheds are not available. Predicted volumes from the watersheds with wet-bank-erosion rates of $14 \mathrm{~mm} / \mathrm{yr}$ (Kahana and Nāpili 4-5) are 1.5-2 times greater than excavated volumes. Predicted sediment volumes for the dry watersheds of Māhinahina and Honokōwai are approximately one-fourth of DPW's average annual removed volumes, although Honokōwai's estimate may not include sediment. If bank-erosion rates for these ephemeral streams are closer to wet values, the predicted load is within a dump-truck load or two of DPW measured values (table 7).

Table 6 shows percent area of each geomorphic process for each subwatershed, and table 10 shows subwatershed sediment loads calculated by multiplying process areas by the hypothetical erosion rates listed in table 2. For decadal storms, the annualized sediment loads, or the decadal-event load divided by 10, range from zero to a high of 180 metric tons/yr at Honolua Stream (table 10). The median annual load is 9 metric tons/yr, with Honolua, Kahana, and Honokōwai watersheds dominating by virtue of their larger drainage areas. Figure 32 illustrates these decadal model results as the yellow sector of the sediment-loading symbol. This calculation illustrates that decadal storms with the potential to transport sediment directly from agricultural fields and erode banks could be the equivalent of 10 years of bank-erosion loading in one event. Put another way, the annual loading from bank erosion is roughly equivalent to spreading a decadal storm's results over 10 years.

The hypothetical annual pre-human sediment load is 22 metric tons/yr for Honokōwai, the largest of West Maui's watersheds, with a median value of 2.9 metric tons/yr for all watersheds (table 10). These hypothetical loads mostly range from one-half to one-tenth of the current values from bank erosion. If true, these model results indicate that historic land use has dramatically increased the load of fine sediment to West Maui's nearshore coral reefs (fig. 32).

\section{Discussion}

\section{Conditions and Source of Annual Sediment Plumes}

West Maui storms with rainfalls above $10-20 \mathrm{~mm} / \mathrm{hr}$ bring coastal sediment plumes that are plausibly sourced from erosion of historic terraces, a legacy of agriculture. These deposits were visibly eroded after the July 19-20, 2014, storm and accessible to channel flows that generated coastal plumes in the hours following the highest rainfall intensities. Poststorm observations of historic terraces indicated that streams entrained sands, silts, and clays during bank erosion at high flow, leaving behind freshly exposed roots. These deposits must have originated during historic times, because of the artifacts that they contain (for example, drip-tape fragments and bottles, figs. 7, 8). Aerial photographs from 1951 show that valley sideslopes were locally covered by aprons of sediment (fig. 11). Our interpretation of this imagery and machine-scraped boulders in the field is that bulldozers pushed mixtures of fine-grained sediment and boulders to the edge or over flow-slope margins (fig. 6). The resulting aprons of material, eroded by overland flow in small alluvial fans, were deposited as historic terraces.

Other sources for plume sediment are less plausible. The July 2014 storm brought rainfalls that were insufficient to generate overland flow in most of the former agricultural fields or unimproved roads of West Maui. The relatively high hydraulic conductivity of these surfaces likely requires very intense storms to generate runoff and erosion. Field observations of machine-disking marks and the absence of widespread evidence for overland flow (for example, fresh rills and gullies) are consistent with measured infiltration rates exceeding common rainfall intensities. Figure 26 shows rainfall intensities above $40 \mathrm{~mm} / \mathrm{hr}$, values that could generate runoff from some roads and fields. The storm of record at the Field 28 gage occurred in December 2007 (the highest red circle in fig. 26) and may have generated runoff from the field. On Moloka'i, the same storm led to as much as $1.6 \mathrm{~cm}$ of soil lowering (Stock and others, 2009, 2010), the largest amount observed to date (2006-2015). Its effect on West Maui may have been similarly large. There is no obvious temporal trend for these geomorphically effective storms, leading to the conclusion that the occurrence of geomorphically effective rainstorms has not detectably changed. The future may bring less total rainfall, reducing vegetation cover and leading to more erosion from the same population of intense storms. This population includes cyclones, synoptically characterized as upper-level troughs or kona lows, as well as cut-off lows. These synoptic characterizations do not uniquely define which storms will bring geomorphically effective rainfalls. Mesoscale boundary conditions appear to force the highintensity rainfalls driving runoff, which complicates efforts to forecast how erosion will change with climate.

\section{Evaluating Sediment Budgets}

The annual sediment budget from bank erosion is constrained by field measurements of bank extent and geometry along four streams and two years of bank-erosion rates from four sites. The resulting models predict annual sediment volumes that agree roughly with Maui DPW estimates for wet watersheds (Nāpili 4-5 and Kahana Gulch) but are approximately one-fourth of the observed values for dry watersheds to the south. Our explanation for this discrepancy is that the bank-lowering rate for dry watersheds may be closer to those of the wet northern watersheds, 3-5 times larger than the $5 \mathrm{~mm} / \mathrm{yr}$ measured at our one dry site, Māhinahina gulch.

When sediment loads enter West Maui's nearshore, imagery indicates that sediment is transported in distinct along-shore cells (figs. 38, 39), consistent with figure 4 in Storlazzi and Field (2008). Figure 38 illustrates sediment plumes in the nearshore from a December 2017 storm. The 
Table 10. Sediment budgets for West Maui watersheds.

$\left[\mathrm{km}^{2}\right.$, kilometers squared; - , no data $]$

\begin{tabular}{|c|c|c|c|c|c|c|c|c|}
\hline $\begin{array}{l}\text { Water- } \\
\text { shed } \\
\text { No. }{ }^{1}\end{array}$ & Watershed name ${ }^{2}$ & $\begin{array}{c}\text { Total area } \\
\left(\mathrm{km}^{2}\right)\end{array}$ & $\begin{array}{l}\text { Estimate of } \\
\text { annual storm } \\
\text { mass load } \\
\text { from bank } \\
\text { erosion }{ }^{1} \\
\text { (metric tons/ } \\
\text { year) }\end{array}$ & $\begin{array}{c}\text { Hypothetical } \\
\text { decadal storm } \\
\text { mass load } \\
\text { annualized } \\
\text { (metric tons/ } \\
\text { year) }\end{array}$ & $\begin{array}{l}\text { Hypothetical } \\
\text { pre-human } \\
\text { mass load }^{3} \\
\text { (metric tons/ } \\
\text { year) }\end{array}$ & $\begin{array}{c}\text { Annualized } \\
\text { yield } \\
\text { (metric tons/ } \\
\text { km²/year) }\end{array}$ & $\begin{array}{c}\text { Amplification } \\
\text { of annual } \\
\text { load over } \\
\text { hypothetical } \\
\text { background } \\
\text { (multiple of } \\
\text { background) }\end{array}$ & $\begin{array}{c}\text { Annual load } \\
\text { as a percent } \\
\text { of annualized } \\
\text { hypothetical } \\
\text { decadal load } \\
\text { (percent) }\end{array}$ \\
\hline 1 & Lipoa Point & 0.35 & 0 & 4 & 0.9 & 0 & 0 & 0 \\
\hline 4 & Mokuleia Bay & 0.48 & 23 & 7 & 1.3 & 48 & 18 & 340 \\
\hline 5 & unnamed & 0.10 & 0 & 1 & 0.2 & 0 & 0 & 0 \\
\hline 6 & Kahauiki & 1.68 & 27 & 18 & 4.0 & 16 & 7 & 146 \\
\hline 7 & unnamed & 0.17 & 0 & 1 & 0.4 & 0 & 0 & 0 \\
\hline 8 & Mokupe'a Gulch & 4.03 & 46 & 33 & 8.8 & 11 & 5 & 141 \\
\hline 12 & unnamed & 0.52 & 0 & 1 & 1.3 & 0 & 0 & 0 \\
\hline 13 & Nāpili 2-3 & 1.98 & 44 & 21 & 5.0 & 22 & 9 & 210 \\
\hline 14 & Nāpili 4-5 & 2.41 & 56 & 28 & 6.0 & 23 & 9 & 200 \\
\hline 15 & unnamed & 0.06 & 0 & 0 & 0.2 & 0 & 0 & - \\
\hline 16 & Honokeana & 1.94 & 43 & 25 & 4.8 & 22 & 9 & 173 \\
\hline 17 & unnamed & 0.25 & 0 & 0 & 0.6 & 0 & 0 & - \\
\hline 18 & unnamed & 0.39 & 0 & 3 & 1.0 & 0 & 0 & 0 \\
\hline 19 & unnamed & 0.06 & 0 & 0 & 0.2 & 0 & 0 & 0 \\
\hline 20 & Ka'ōpala Gulch & 2.36 & 62 & 27 & 5.6 & 26 & 11 & 226 \\
\hline 21 & unnamed & 0.44 & 0 & 5 & 1.1 & 0 & 0 & 0 \\
\hline 22 & Kahana Stream & 11.68 & 285 & 125 & 21.4 & 24 & 13 & 229 \\
\hline 30 & Hanaka'ô‘ ${ }^{\prime}$ & 5.94 & 26 & 63 & 13.2 & 4 & 2 & 41 \\
\hline 31 & Kahua & 1.65 & 25 & 22 & 4.2 & 15 & 6 & 115 \\
\hline 32 & unnamed & 1.12 & 0 & 3 & 2.9 & 0 & 0 & 0 \\
\hline 33 & Kā'anapali & 2.65 & 0 & 26 & 6.7 & 0 & 0 & 0 \\
\hline 34 & Black Rock 2 & 2.14 & 0 & 12 & 5.5 & 0 & 0 & 0 \\
\hline 35 & Wahikuli Gulch & 10.42 & 42 & 70 & 18.6 & 4 & 2 & 60 \\
\hline
\end{tabular}

${ }^{1}$ These watersheds are equivalent to larger watershed groupings: $1-4$, Honolua watershed, $12.06 \mathrm{~km}^{2} ; 5-10$, Honokahua watershed, $12.76 \mathrm{~km}^{2} ; 11-23$, Kahana watershed, $23.16 \mathrm{~km}^{2} ; 24-28$, Honokōwai watershed, $23.03 \mathrm{~km}^{2} ; 29-35$, Wahikuli watershed, $24.28 \mathrm{~km}^{2}$.

${ }^{2}$ Italics, informal name.

${ }^{3}$ Assumes 1,300 kilograms per cubic meter bulk density.

northern cell sources discharge from Honolua and Honokahua Streams and the central cell is fed by Ka'opala Gulch, Kahana Stream, and Honokōwai Stream. Sediment from this event did not reach the southern cell (fig. 39) that includes discharge from Wahikuli gulch. Figure 39 illustrates what the annual nearshore sediment budget from plume loading would be for this pattern. It shows that the highest sediment pollution occurs to the south of Ka'oppala Gulch and Kahana Stream, with the Honokōwai Stream nearshore loaded by $\sim 60$ dumptruck loads of fine sediment (596 metric tons) every year.

Erosion rates used in the decadal sediment budget are hypothetical, so these budgets must be viewed with skepticism until we can estimate rates from field measurement or monitoring. In the Methods section, we reasoned that suspended loads from rockfall areas would be a fraction of $0.1 \mathrm{~mm} / \mathrm{yr}$. As a crude test of the notion that this value 

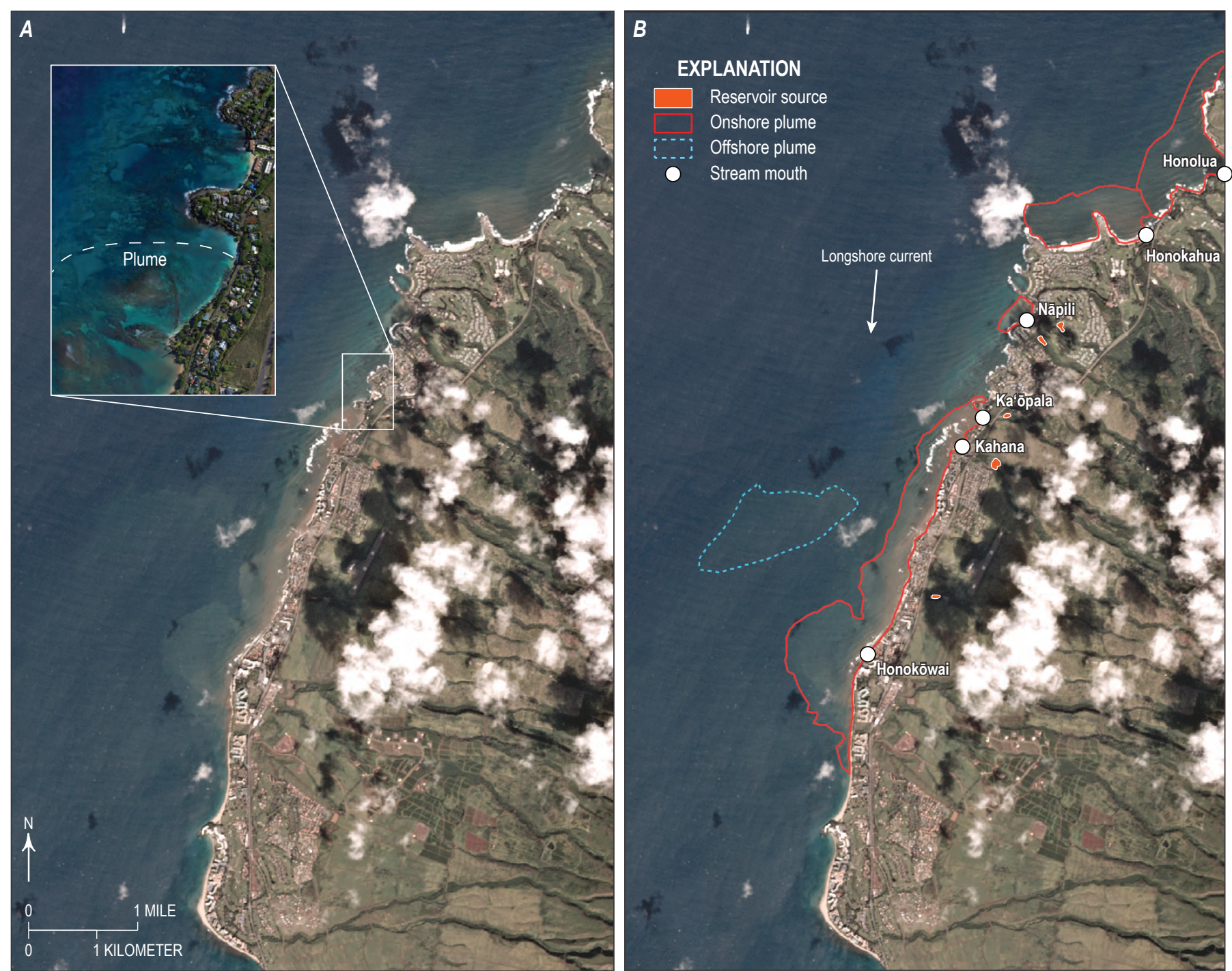

Figure 38. Planet satellite imagery over West Maui showing December 22, 2017, nearshore plume $(A)$ and interpreted plume boundary and sources $(B)$. Reservoirs at Ka'ōpala and Kahana are filled with brown runoff, discharging turbid water to the nearshore. Plume inputs are concentrated at Ka'ōpala and Kahana, consistent with the results from the sediment budget in figure 37 . This sediment was then pushed by a longshore current to south of Honokōwai where it detaches from shore. Inset $(A)$ shows 7/8/2016 DigitalGlobe imagery, illustrating sediment deposition on reefs (brown tones) from historic plumes. Planet imagery courtesy of Planet Team (2017). Planet Application Program Interface: In Space for Life on Earth. San Francisco, CA.

approximates the suspended load from rockfall areas, we plotted lowering rates calculated from suspended-sediment yields on O'ahu, Moloka'i, and Kaua'i (table 11; fig. 40). These watershed-wide values, expressed as the point-lowering rate of a low bulk-density soil of density $950 \mathrm{~kg} / \mathrm{m}^{3}$, range from 0.03 to $0.8 \mathrm{~mm} / \mathrm{yr}$ for records over 5 years in length. The majority of measurements are biased towards watersheds with land-use disturbance that created a waterquality problem requiring monitoring. These include loss of vegetation (see, for example, Stock and Tribble, 2010), construction (for example, North Hālawa Valley watershed, $\mathrm{O}^{\prime} \mathrm{ahu}$ ), and in-channel modifications (for example, Waikele Stream watershed on $\mathrm{O}^{\prime} \mathrm{ahu}$ ). These sediment yields are much greater than $0.1 \mathrm{~mm} / \mathrm{yr}$. Moanalua Stream on O'ahu, the only watershed with relatively intact vegetation and a lack of disturbance, has a sediment yield equivalent to a soil-lowering rate of $\sim 0.05 \mathrm{~mm} / \mathrm{yr}$. It has a steepland headwater with intact canopy. It is perhaps most comparable to the rockfall portions of Honokōwai Stream and Honolua Stream watersheds on Maui. This value is crudely consistent with the value of 0.03 $\mathrm{mm} / \mathrm{yr}$ suspended-load production we assume for rockfall areas of West Maui.

There is an observation gap about what erosion rates happen during sustained, heavy rainfalls (for example, December 2007) on former agricultural fields and sideslopes. These sediment sources are extensive enough to produce large coastal plumes if runoff carries their sediments to channels. Lowering rates generated by rainsplash and Horton overland 


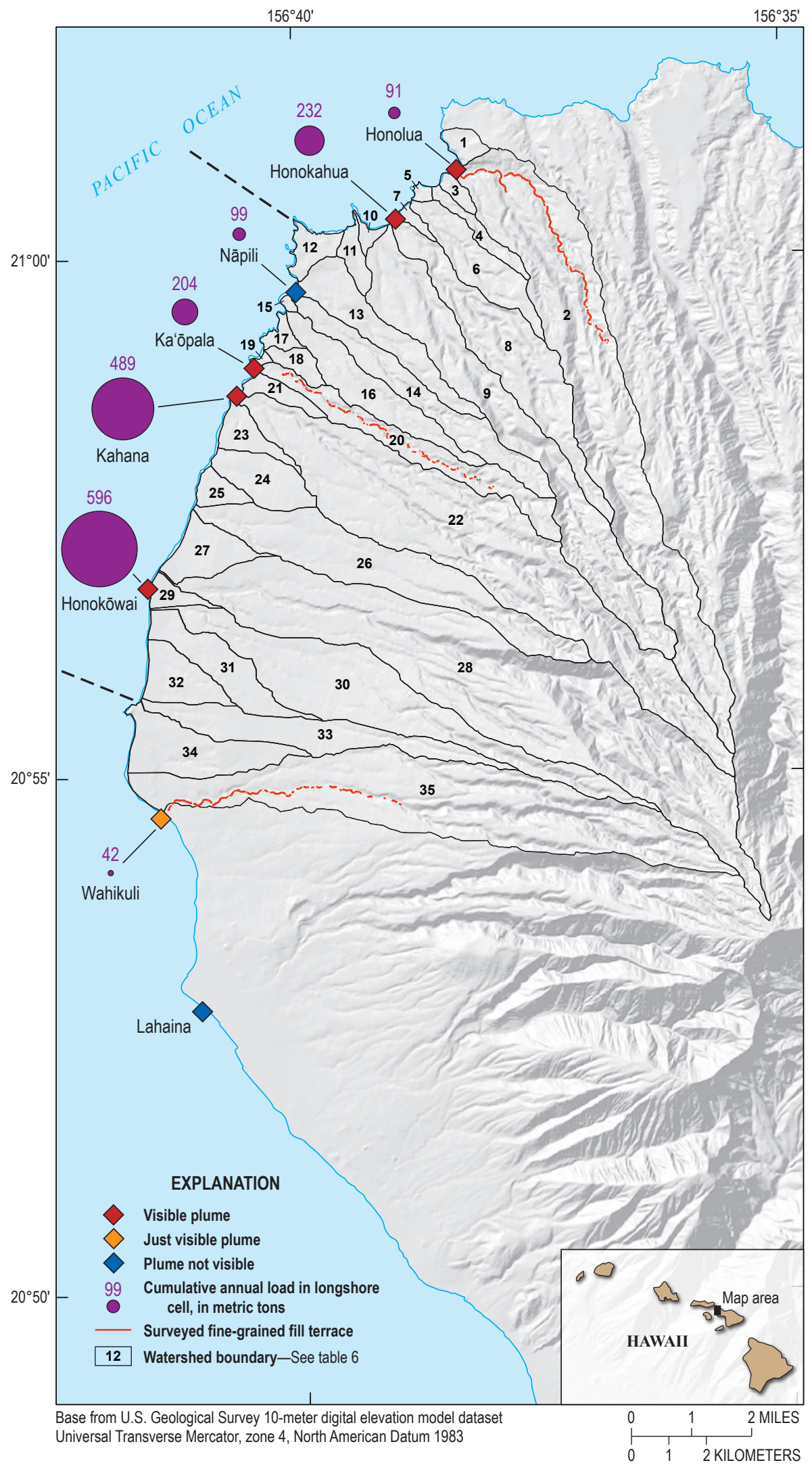

Figure 39. Illustration of simple three-cell longshore aggregation model for sediment pollution, showing longshore accumulation in metric tons, based on plume behavior in figure 38. Thick black dashed lines represent possible cell boundaries, consonant with Storlazzi and Field, 2008. 
Table 11. Compilation of estimates of Hawaiian lowering rates.

[For island-wide analyses, we used a default area of $100 \mathrm{~km}^{2}$. Ca, calcium; Cs, cesium; He, helium. PIWSC, Pacific Islands Water Science Center, U.S. Geological Survey]

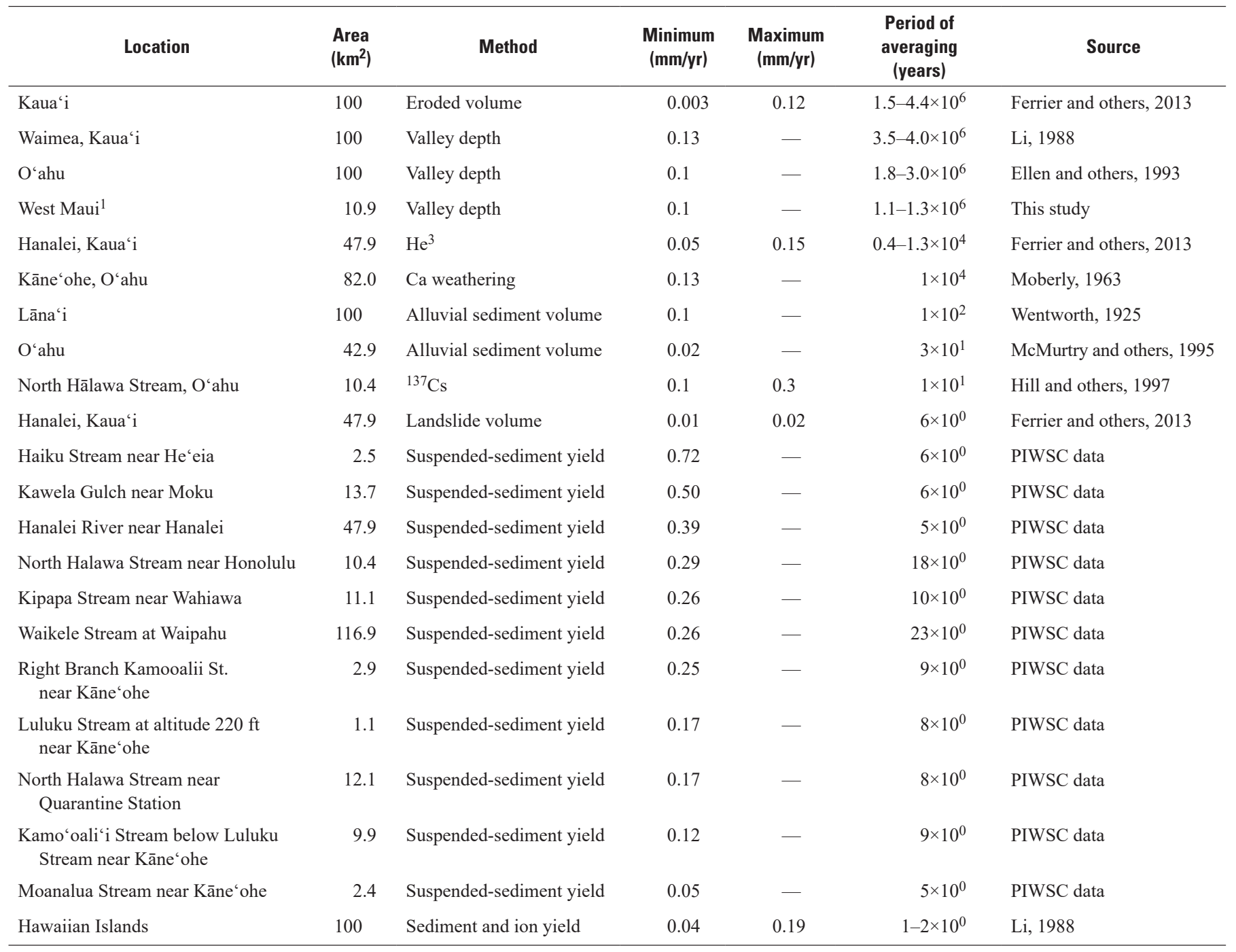

${ }^{1}$ Honokahua Stream watershed at Mahana (fig. 2).

flow in former agricultural fields are equally unknown. A case can be made that many of these areas experience sustained $(>1$ hour) runoff less than once a decade (for example, fig. 28A, Field 46). Corresponding lowering rates must be small over the last million years, given the absence of channelization into these flow-slope surfaces. Whether or not such areas contribute to coastal plumes during very intense rainfalls depends on their present connection to the valley network, a legacy of field engineering.

\section{Potential Tool for Prioritizing In-stream Mitigation}

A map of the relative rates of bank erosion for problematic watersheds might help prioritize site-level mitigation. If bank erosion co-varies with reach-averaged shear stresses from flowing water, a map of this stress would serve that need. We estimate this stress using a simple expression that assumes steady flow and omits convective accelerations and other stresses that depend on local site conditions:

$$
\tau_{\mathrm{b}}=\rho \mathrm{gDS}
$$

where

$$
\begin{aligned}
\tau_{\mathrm{b}}= & \text { basal shear stress }\left[\mathrm{N} / \mathrm{m}^{2}\right] \\
\rho= & \text { density of water }\left[\mathrm{kg} / \mathrm{m}^{3}\right] \\
\mathrm{g}= & \text { gravity }\left[\mathrm{m} / \mathrm{sec}^{2}\right] \\
\mathrm{D}= & \text { bankfull depth }[\mathrm{m}] \\
\mathrm{S}= & \text { water surface slope (approximated as } \\
& \text { channel slope) }
\end{aligned}
$$




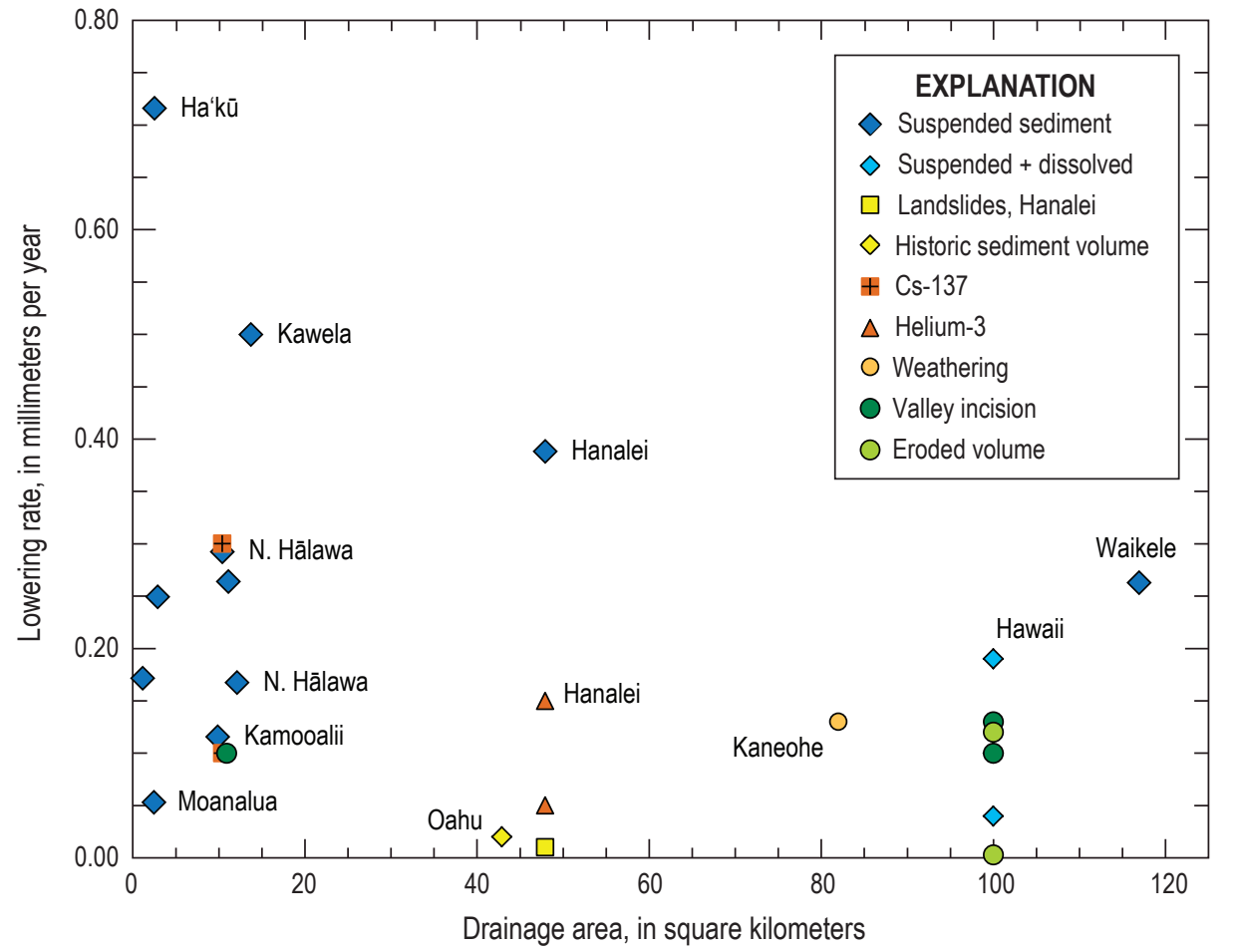

Figure 40. Published erosion rates for the Islands of Kaua'i, O'ahu, Moloka'i, Lāna'i, and Hawaii' (see table 11), expressed as the lowering rate of a 950-kilogram-per-cubicmeter $(\mathrm{kg} / \mathrm{m} 3)$ bulk-density soil. See table 11 for source data. Rates from suspendedsediment yield exclude bedload, which may be substantial (>10 percent by weight). Rates from valley incision omit hillslope processes, which may also be substantial. Terrain that is altered by vegetation loss or construction (for example, Ha'ikū, Kawela, and Hālawa) have lowering rates in excess of 0.2 millimeters per year ( $\mathrm{mm} / \mathrm{yr})$. Longterm valley incision rates are approximately $0.1 \mathrm{~mm} / \mathrm{yr}$. The least disturbed landscapes may have lowering rates from 0.01 to 0.05 $\mathrm{mm} / \mathrm{yr}$ (for example, Moanalua). These rates may approximate the yields from undisturbed terrain dominated by soil creep and rockfall, like the headwaters of West Maui valleys.
We generated a stream network using the 10-m DEM and derived slope-map, flow-direction, and flow-accumulation rasters. We used the 10-m slope map to assign a slope, $\mathrm{S}$, for each pixel. To determine the bankfull depth, D, at each pixel, we used the relation between drainage area, A, and bankfull depth, D. From figure 30, hydraulic radius D is:

$$
\mathrm{D}=0.42 \mathrm{~A}^{0.38}
$$

We input the flow accumulation raster as $\mathrm{A}$ in equation 2 to calculate $\mathrm{D}$ for each stream pixel. At each pixel along that stream network, we calculated the basal shear stress in (1) using the pixel slope and the calculated value of D from (2). For purposes of creating a simplified map, we assigned shear stresses, using quartiles, to low $(0-0.560 \mathrm{kPa})$, medium $(0.560-0.940 \mathrm{kPa})$, and high $(0.9409 .55 \mathrm{kPa})$. The low category encompasses the lowest two quartiles; medium is $50-75$ percent and high is $75-100$ percent of the data.

The resulting map, illustrated for the Ka'ōpala Gulch watershed shown in figure 41, is a crude estimate of reachaveraged shear stress. Known waterfall sections tend to dominate the red, high shear-stress category. These estimates can be compared to bankfull estimates from surveys at the erosion-pin cross sections in table 7, ranging from 0.1 to 0.4 $\mathrm{kPa}$, corresponding to the low shear-stress category (green) in figure 41. Both techniques are estimates of stresses from steady, uniform flow. They neglect stresses from convective accelerations due to channel curvature and along-reach changes in friction or slope and do not account for bank material resistance, which is variable (table 8). These effects may dominate bank-erosion rate locally, so maps of reach-averaged shear stress should be used with caution. For instance, table 7 shows that reach-averaged shear stresses do not always co-vary with erosion rate: Honolua has approximately twice the bankfull reach-averaged shear stress but smaller bank erosion rates for material that is only slightly stronger at high stresses $(3.7 \mathrm{kPa})$ than bank material at Pāpua 1 and $2(2.7-3.4 \mathrm{kPa})$. Jet tests illustrate that fine-grained fill terraces in West Maui begin to erode at water stresses of $0.6 \mathrm{kPa}$ (fig. 36), a value that exceeds the estimates of reachaveraged shear stresses from the depth-slope product (table 8). Reach-averaged estimates of shear stress almost certainly underestimate the transient, local Reynolds stresses during flow. There is no apparent geographic pattern in cohesion (fig. 41), so a threshold value of $0.6 \mathrm{kPa}$ from field tests is a likely first approximation for the central tendency values of cohesion in West Maui historic fill terraces.

There is also a need for a model to predict the flow depth that covaries with rainfall intensity as a way of estimating bank-area eroding during a storm. Figure 42 illustrates one crude approach that uses historic hourly rainfalls that generated plumes along with hydraulic geometry. In this case, we assumed that fill terraces begin to erode when the flow hydraulic radius reaches $0.2 \mathrm{~m}$, a common estimate for the first exposure of a fill terrace above a channel bed. To calibrate this approach, we assumed that the smaller July 2014 plume event was triggered by flows that just began to inundate this $0.2-\mathrm{m}$ level at the largest drainage areas of approximately 15 square kilometers $\left(\mathrm{km}^{2}\right)$, and the larger September 2016 event started eroding 0.2-m-high banks at a smaller drainage area of $1 \mathrm{~km}^{2}$. These choices set the intercept for the relation between hydraulic radius and drainage area, and they set the rainfall 


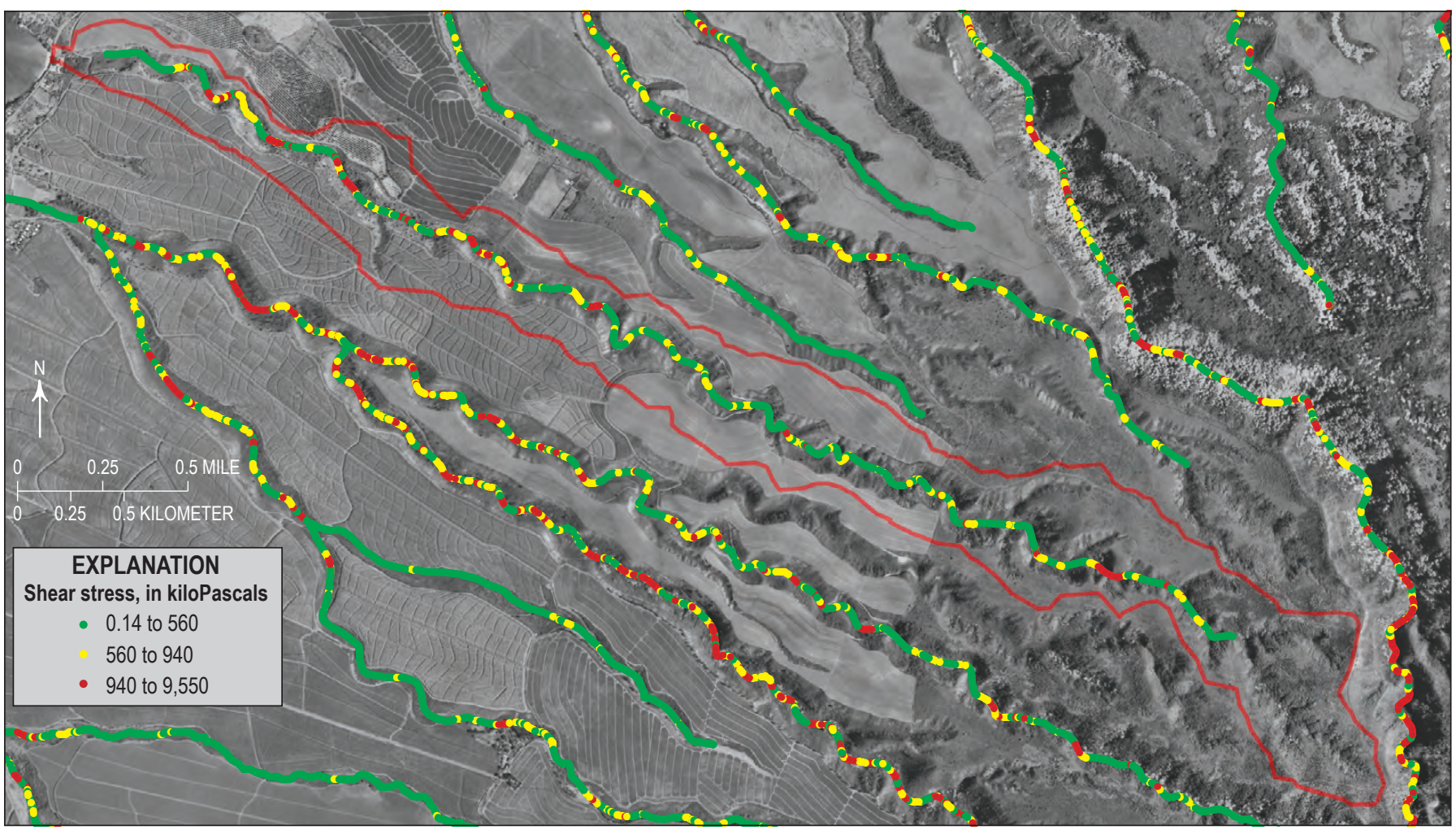

Figure 41. Map of reach-averaged shear stress estimated for Ka'ōpala Gulch (red outline) using hydraulic geometry and the 10-meter (10-m) USGS digital elevation model (DEM). The DEM provides estimates of 10-m slope, and the drainage-area value at these same cells can be substituted into the hydraulic geometry relation in figure $30 \mathrm{~A}$ to estimate bankfull depth. The reach-average shear stress is the product of the DEM slope, flow depth, and two constants ( $g$ and water density). The map is a very crude estimate of reach-average shear stress, where steep-waterfall sections tend to dominate the red (high) category. These estimates can be compared to bankfull estimates from surveys at the erosion-pin cross sections in table 7 , ranging from 0.1 to 0.4 kiloPascals. Yellow and red categories span the range of estimated bank cohesion values in figure 36 .

intensities that correspond to these events at $10 \mathrm{~mm} / \mathrm{hr}$ and $28.4 \mathrm{~mm} / \mathrm{hr}$. Assuming bankfull conditions occur at hourly rainfalls with a 2-year recurrence interval $(53 \mathrm{~mm} / \mathrm{hr}$ at Field 46) completes the model for estimating hydraulic-radius intercept as a function of hourly rainfall rate. We doubt these numbers would be a final choice for this relation, but the technique illustrates how one could use events to calibrate a bank-exposure model to prioritize mitigation.

\section{Long-Term Sediment Sources from Large Landslides}

Mapped large landslides (units Is and Iss, accompanying map plate) are covered by canopied forests with no contrast at landslide boundaries. We interpret them to be prehistoric. Downstream of the slide body, some valleys widen abruptly. This boundary sometimes coincides with lineaments normal to the valley axis, which are possibly the surface expression of dikes. One hypothesis is that elevated water tables upstream of dikes that cut across the valley slopes increase the susceptibility to deep-seated failures. The resultant large landslides widen the valley above the dikes and produce large volumes of coarse material that migrate downstream as terraces, aggrading the valley. Following incision, these deposits remain as the many paired terraces (unit tr) shown on the accompanying map plate, evidence for episodic highsediment supply. If this is a common sequence of events, many Hawaiian valleys owe their width and sidewall profile to large landslides. Consequently, the majority of the erosion of Hawaiian edifices may be accomplished by large landslides, with boundary lowering driven by rockfall and debris-flow incision of valleys. The widespread presence of debris-flow deposits above 3-5 percent valley gradients on Moloka'i and West Maui would be consistent with this hypothesis.

\section{Conclusion}

We conclude that the nearshore sediment plumes that now happen every year off West Maui come from streambank erosion of historic fill terraces, deposited as a legacy of agriculture. Field observations during and after the July 2014 sediment plumes indicated that other watershed sources did not contribute runoff. Measured hydraulic conductivities of fields and roads (averaging $50 \mathrm{~mm} / \mathrm{hr}$ ) are much larger than rainfall intensities now triggering coastal plumes $(10-20 \mathrm{~mm} / \mathrm{hr}$ 


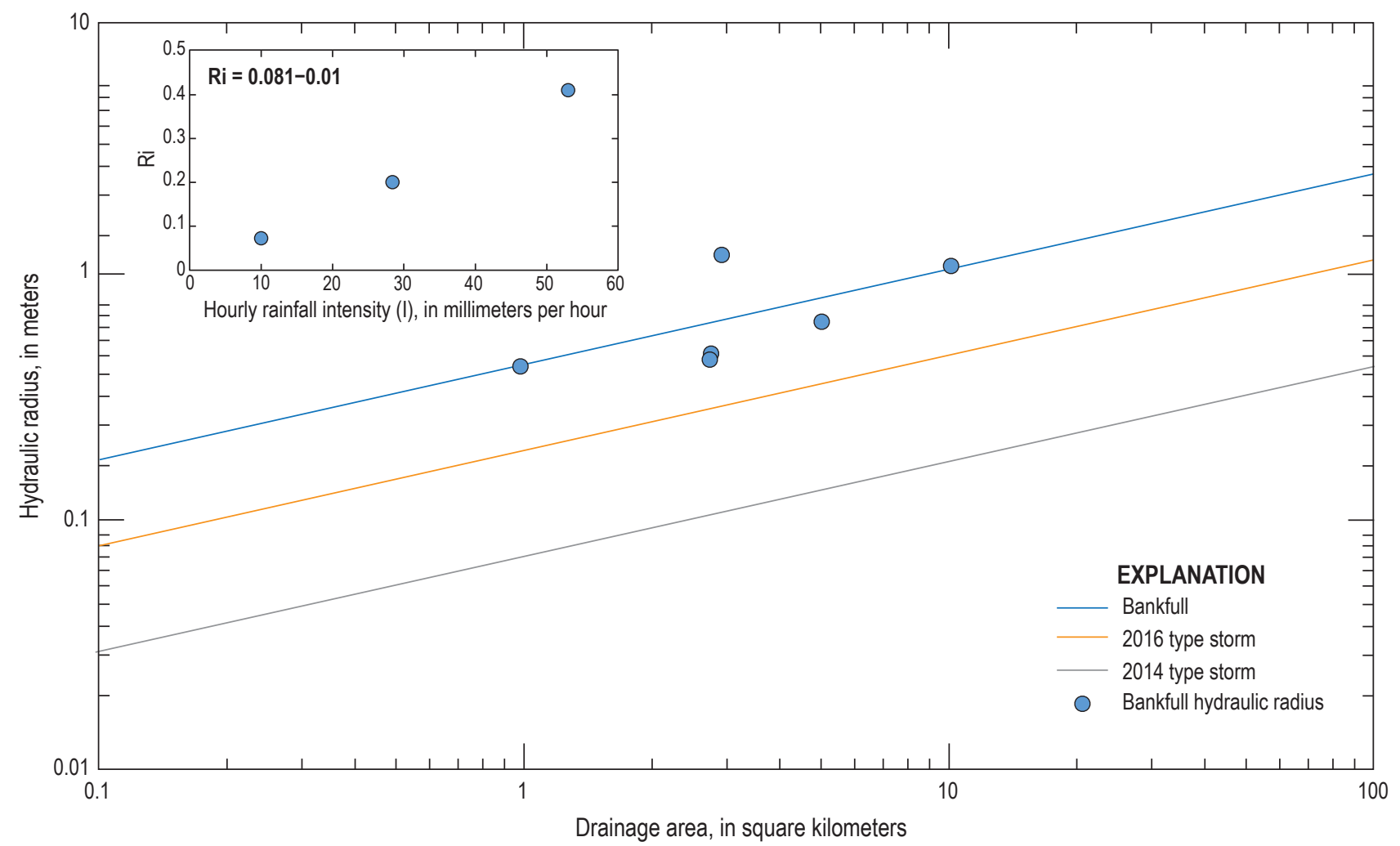

Figure 42. Example of a simple model for bank inundation throughout West Maui's streams, based on correlating rainfall intensity with flow depth at a given drainage area and using hydraulic geometry to extend the correlation through the stream network. Inset shows I as hourly rainfall intensity and $\mathrm{Ri}$ as the intercept on the power-law relation between hydraulic radius and drainage area (see fig. 30A for example). Blue dots represent bankfull hydraulic radius at sites in table 7 . See text for more details.

of rain for two or more hours). Synoptic storm types, including cyclones from upper-level troughs and kona lows and cut-off lows, have the ability to produce the $10-20 \mathrm{~mm} / \mathrm{hr}$ rainfalls that generate bank erosion and coastal plumes. A small number of these storms also have higher rainfall intensities capable of eroding agricultural fields for an hour or longer. These occurred four to five times per decade during the 1980s and 2000s but only twice during the 1990s. Although annual rainfall totals have decreased over the last three decades, there is no evidence that geomorphically effective storms have become less frequent.

Surveys show that West Maui's streams have historic fill terraces adjacent to, or downstream of, agricultural fields, where they form $\sim 40$ percent of the streambank length. These silt and fine-sand terraces were likely deposited from sidecasting of excess agricultural soils into valleys. Tests of bank-material cohesion suggest that erosion initiates at values of water stress at or under bankfull reach-averaged shear stresses at most sites. Stresses from convective water accelerations and tool impacts likely drive lowering. Terraces currently erode at rates from 5 to $24 \mathrm{~mm} / \mathrm{yr}$, feeding annual nearshore sediment plumes. A crude but defensible sediment budget indicates that this annual bank erosion sends a minimum of $\sim 920$ tons of fine sand, silt, and clay to West
Maui's nearshore, the equivalent of about 93 dump-truck loads per year. Uncertainties in bank erosion rate imply that actual sediment loads could be 30-360 percent of estimated values. The sediment budget predicts that Kahana Stream produces almost a third of this total. Most watershed-sediment yields range from 4 to 26 metric tons $/ \mathrm{km}^{2} / \mathrm{yr}$, with Ka'ōpala Gulch having the highest sediment yield of the larger watersheds. The annual loads from bank erosion plausibly represent $\sim 10$ times the likely prehistoric-watershed load values, although the constraints on this calculation need great improvement.

This sediment budget implies that treatments of former agricultural fields, roads, and reserve forests are not likely to measurably affect sediment pollution from annual storms. The presence of coastal plumes from some streams does indicate that upstream sediment-retention basins are not stopping the load from all small storms. If development proceeds, experience in urbanized systems indicates that high flows will become more frequent as concrete and asphalt surfaces concentrate rainfall from more rapid runoff into stream channels. Higher, more frequent flows will accelerate bank erosion without mitigation. West Maui will continue to experience annual nearshore sediment pollution unless an effective strategy is developed to reduce bank erosion, or its effects. 


\section{References Cited}

Anthony, K.R.N., and Connolly, S.R., 2004, Environmental limits to growth; physiological niche boundaries of corals along turbidity-light gradients: Oecologia, v. 141, p. 373-384, accessed 1/5/2020, at https://link.springer.com/ article/10.1007/s00442-004-1647-7.

Belmont, P., Gran, K.B., Schottler, S.P., Wilcock, P.R., Day, S.S., Jennings, C., Lauer, J.W., Viparelli, E., Willenbring, J.K., Engstrom, D.R., and Parker, G., 2011, Large shift in source of fine sediment in the Upper Mississippi River: Environmental Science and Technology, v. 45, p. 88048810, accessed 1/5/2020 at https://www.ncbi.nlm.nih.gov/ pubmed/21879734.

Chu, P.-S., and Chen, H., 2005, Interannual and interdecadal rainfall variations in the Hawaiian Islands: Journal of Climate, v. 18, p. 4796-4813, accessed 1/5/2020 at https://journals.ametsoc.org/doi/full/10.1175/JCLI3578.1.

Davies, P.S., 1991, Effects of daylight variations on the energy budgets of shallow-water corals: Marine Biology, v. 108, p. 137-144, accessed 1/5/2020 at https://link.springer.com/ article/10.1007/BF01313481.

Dietrich, W.E., and Dunne, T., 1978, Sediment budget for a small catchment in mountainous terrain: Annals of Geomorphology Supplement, v. 29, p. 191-206, accessed 1/5/2020 at http://wpg.forestry.oregonstate.edu/sites/wpg/ files/seminars/1978_Dietrich\%26Dunne.pdf.

Dietrich W.E., Dunne T., Humphrey, N.F., and Reid, L.M., 1982, Construction of sediment budgets for drainage basins, in Sediment budgets and routing in forested drainage basins: United States Department of Agriculture General Technical Report PNW-141, p. 5-24.

Dunne, Thomas, and Leopold, L.B., 1978, Water in environmental planning: New York, W. H. Freeman and Company.

Edmondson, C.H., 1928, The ecology of an Hawaiian coral reef: Bulletin of the Bernice P. Bishop Museum, Bulletin 45, $64 \mathrm{p}$.

Ellen, S.D, Mark, R.K., Cannon, S.H., and Knifong, D.L., 1993, Map of debris-flow hazard in the Honolulu District of Oahu, Hawaii: U.S. Geological Survey Open-File Report 93-213, 28 p., accessed 1/5/2020 at http://pubs.usgs.gov/ of/1993/of93-213/.

El-Swaify, S.A., Dangler, E.W., and Armstrong, C.L., 1982, Soil erosion by water in the tropics: Honolulu, University of Hawaii, Hawaii Institute of Tropical Agriculture and Human Resources, Research extension series 024, 173 p.
Fabricius, K.E., 2005, Effects of terrestrial runoff on the ecology of corals and coral reefs; review and synthesis: Marine Pollution Bulletin, v. 50, p. 125-146, accessed 1/5/2020 at https://www.sciencedirect.com/science/article/ abs/pii/S0025326X04004497.

Ferrier, K.L., Perron, J.T., Mukhopadhyay, S., Rosener, M., Stock, J.D., Huppert, K.L., and Slosberg, M., 2013, Covariation of climate and long-term erosion rates across a steep rainfall gradient on the Hawaiian island of Kaua' $i$ : Geological Society of America Bulletin, v. 125, p. 11461163, accessed 1/5/2020 at https://pubs.geoscienceworld. org/gsa/gsabulletin/article/125/7-8/1146/125923/

Covariation-of-climate-and-long-term-erosion-rates.

Gellis, A.C., Pavich, M.J., Ellwein, A.L., Aby, S., Clark, I., Wieczorek, M.E., and Viger, R., 2012, Erosion, storage, and transport of sediment in two subbasins of the Rio Puerco, New Mexico: Geological Society of America Bulletin, v. 124, p. 817-841, accessed 1/5/2020 at https://pubs.geoscienceworld.org/gsa/gsabulletin/articleabstract/124/5-6/817/125813/Erosion-storage-and-transportof-sediment-in-two?redirectedFrom $=$ fulltext.

Gellis, A.C., Webb, R.M., Wolfe, W.J., and McIntyre, S.C., 1999, Effects of land use on upland erosion, sediment transport, and reservoir sedimentation, Lago Loiza basin, Puerto Rico: U.S. Geological Survey Water-Resources Investigations Report 99-4010, accessed 1/5/2020 at https://doi.org/10.3133/wri994010.

Gilbert, G.K., 1909, The convexity of hilltops: Journal of Geology, v. 17, p. 344-350.

Gilmour, J., 1999, Experimental investigation into the effects of suspended sediment on fertilisation, larval survival and settlement in a scleractinian coral: Marine Biology, v. 135, p. 451-462, accessed 1/5/2020 at https://link.springer.com/ article/10.1007/s002270050645.

Granger, D.E., Kirchner, J.W., and Finkel, R., 1996, Spatially averaged long-term erosion rates measured from in situproduced cosmogenic nuclides in alluvial sediment: Journal of Geology, v. 104, p. 249-257, accessed 1/5/2020 at https://www.jstor.org/stable/30068190?seq=1.

Green, R.E., Ahuja, L.R., Chong, S.-K., and Lau, L.S., 1982, Water conduction in Hawaii oxic soils: University of Hawaii at Manoa, Water Resources Research Center Technical Report 143, 122 p.

Hill, B.R., Fuller, C.C., and DeCarlo, E.H., 1997, Hillslope soil erosion estimated from aerosol concentrations, North Halawa Valley, Oahu, Hawaii: Geomorphology, v. 20, p. 67-79. 
Jokiel, P.L., Rodgers, K.S., Storlazzi, C.D., Field, M.E., Lager, C.V., and Lager, D., 2014, Response of reef corals on a fringing reef flat to elevated suspended-sediment concentrations, Moloka'i, Hawaii: PeerJ, Biodiversity and Conservation Section, v. 2, no. e699, accessed 1/5/2020 at https://www.ncbi.nlm.nih.gov/pmc/articles/PMC4304865/.

Kodama, K.R., and Barnes, G.M., 1997, Heavy rain events over the south-facing slopes of Hawaii: Weather and Forecasting, v. 12, no. 2, p. 347-367, accessed 1/5/2020 at https://doi.org/10.1175/1520-0434(1997)012<0347:HREOT $\mathrm{S}>2.0 . \mathrm{CO} ; 2$.

Li, Y.-H., 1988, Denudation rates of the Hawaiian Islands by rivers and groundwaters: Pacific Science, v. 42, p. 253-266.

McMurtry, G.M., Snidvongs, A., and Glenn, C.R., 1995, Modeling sediment accumulation and soil erosion with $137 \mathrm{Cs}$ and $210 \mathrm{~Pb}$ in the Ala Wai Canal and central Honolulu watershed, Hawaii: Pacific Science, v. 49, p. 412451, accessed 1/5/2020 at https://www.researchgate.net/ publication/29737595_Modeling_Sediment_Accumulation_ and_Soil_Erosion_with_137Cs_and_210Pb_in_the_Ala Wai_Canal_and_Central_Honolulu_Watershed_Hawai'i.

Moberly, R., Jr., 1963, Rate of denudation in Hawaii: Journal of Geology, v. 71, p. 371-375.

National Oceanic and Atmospheric Administration, 2014, Climate data online: National Centers for Environmental Information database [formerly National Climatic Data Center], accessed July 25, 2014, at http://www.ncdc.noaa. gov/cdo-web/.

Oki, D.S., 2004, Trends in streamflow characteristics at longterm gaging stations, Hawaii: U.S. Geological Survey Scientific Investigations Report 2004-5080, 120 p, accessed 1/5/2020 at https://pubs.usgs.gov/sir/2004/5080/.

Patterson, S.H., 1971, Investigations of ferruginous bauxite and other mineral resources on Kauai and a reconnaissance of ferruginous bauxite deposits on Maui, Hawaii: U.S. Geological Survey Professional Paper 656, 74 p.

Perez III, K., Rodgers, K.S., Jokiel, P.L., Lager, C.V., and Lager, D.J., 2014, Effects of terrigenous sediment on settlement and survival of the reef coral Pocillopora damicornis: PeerJ, v. 2, no. e387, accessed 1/5/2020 at https://www.ncbi.nlm.nih.gov/pmc/articles/PMC4034646/.

Reid, L.M., and Dunne, T., 1996, Rapid evaluation of sediment budgets: Germany, Reiskirchen, Catena Verlag GMBH, 164 p.
Reid, L.M., and Dunne, T., 2016, Sediment budgets as an organizing framework in fluvial geomorphology, in Kondolf, G.M., and Piégay, Hervé, Tools in fluvial geomorpholgy (2nd ed.): Wiley Online Library, John Wiley \& Sons, Ltd., chap. 16, p. 357-380, accessed 1/5/2020 at https://doi.org/10.1002/9781118648551.ch16.

Roering, J.J., Kirchner, J.W., and Dietrich, W.E., 1999, Evidence for nonlinear, diffusive sediment transport on hillslopes and implications for landscape morphology: Water Resources Research, v. 35, p. 853-870, accessed 1/5/2020 at http://seismo.berkeley.edu/ kirchner/ reprints/1999_29_Roering_nonlinear.pdf.

Russell, M.A., Walling, D.E., and Hodgkinson, R.A., 2001, Suspended sediment sources in two small lowland agricultural catchments in the UK: Journal of Hydrology, v. 252 , p. $1-24$, accessed $1 / 5 / 2020$ at https://www. sciencedirect.com/science/article/pii/S0022169401003882.

Sherrod, D.R., Sinton, J.M., Watkins, S.E., and Brunt, K.M., 2007, Geologic map of the State of Hawaii: U.S. Geological Survey Open-File Report 2007-1089, pamphlet 83 p., 8 pls., scales 1:100,000 and 1:250,000, available at http://pubs.usgs.gov/of/2007/1089/.

Stearns, H.T., and Macdonald, G.A., 1942, Geology and ground-water resources of the island of Maui, Hawaii: Hawaii (Terr.) Division of Hydrography, Bulletin 7, 344 p., 2 maps, scale 1:62,500.

Stock, J.D., Hanshaw, M.N., Rosener, M., Schmidt, K.M., Brooks, B.A., Tribble, G., and Jacobi, J., 2009, Hillslope-channel coupling in a steep Hawaiian catchment accelerates erosion rates over 100-fold [abs.]: American Geophysical Union, Fall Meeting 2009 Abstracts, abstract no. EP53E-04, available at https:/ui.adsabs.harvard.edu/ abs/2009AGUFMEP53E..04S/abstract.

Stock, J.D., Rosener, M., Schmidt, K.M., Hanshaw, M.N., Brooks, B.A., Tribble, G., and Jacobi, J. 2010, Sediment budget for a polluted Hawaiian reef using hillslope monitoring and process mapping [abs.]: American Geophysical Union, Fall Meeting 2010 Abstracts, abstract no. EP22A-01, available at https://ui.adsabs.harvard.edu/ abs/2010AGUFMEP22A..01S/abstract.

Stock, J.D., and Tribble, G., 2010, Erosion and sediment loads from two Hawaiian watersheds, in Joint Federal Interagency Conference, 2nd, Las Vegas, Nev., June 27July 1, 2010, Proceedings: Advisory Committee on Water Information, accessed April 13, 2015 at http://acwi.gov/sos/ pubs/2ndJFIC/Contents/11D_Stock_02_28_10.pdf. 
Storlazzi, C.D. and Field, M.E., 2008, Winds, waves, tides, and the resulting flow patterns and fluxes of water, sediment, and coral larvae off west Maui, Hawaii: U.S. Geological Survey Open-File Report 2008-1215, 13 p., accessed 1/5/2020 at http://pubs.usgs.gov/of/2008/1215/.

Storlazzi, C.D., Norris, B.K., and Rosenberger, K.J., 2015, The influence of grain size, grain color, and suspended-sediment concentration on light attenuation-Why fine-grained terrestrial sediment is bad for coral reef ecosystems: Coral Reefs, v. 34, p. 967-975, accessed 1/5/2020 at https://link.springer.com/article/10.1007/s00338-015-1268-0.

Storlazzi, C.D., Reguero, B., Lowe, E., Shope, J.B., Gibbs, A.E., Beck, M.W., and Nickel, B., 2017, Rigorously valuing the role of coral reefs in coastal protection-An example from Maui, Hawaii, U.S.A.: Coastal Dynamics, p. 665-674, accessed 1/5/2020 at http://coastaldynamics2017.dk/ onewebmedia/035_storlazzi.pdf.

Tolhurst, T.J., Black, K.S., Shayler, S.A., Mather, S., Black, I., Baker, K., and Paterson, D.M., 1999, Measuring the in situ erosion shear stress of intertidal sediments with the cohesive strength meter (CSM): Estuarine, Coastal and Shelf Science, v. 49, p. 281-294, accessed 1/5/2020 at https://www. researchgate.net/publication/223176344_Measuring_the in_situ_Erosion_Shear_Stress_of_Intertidal_Sediments_ with_the_Cohesive_Strength_Meter_CSM.

van Genuchten, M.Th., 1980, A closed-form equation for predicting the hydraulic conductivity of unsaturated soils: Soil Science Society of America Journal, v. 44, p. 892-898.
Vardy, S., Saunders, J.E., Tolhurst, T.J., Davies, P.A, and Paterson, D.M., 2007, Calibration of the high-pressure cohesive strength meter (CSM): Continental Shelf Research, v. 27 , p. 1190-1199, accessed 1/5/2020 at https://www. sciencedirect.com/science/article/pii/S0278434307000118.

Walling, D.E., Russell, M.A., Hodgkinson, R.A., and, Zhang, T., 2002, Establishing sediment budgets for two small lowland agricultural catchments in the UK: Catena, v. 47, no. 4, p. 323-353, accessed $1 / 5 / 2020$ at https://www.sciencedirect.com/science/article/abs/pii/ S0341816201001874.

Warrick, J.A., Bountry, J.A., East, A.E., Magirl, C.S., Randle, T.J., Gelfenbaum, G., Ritchie, A.C., Pess, G.R., Leung, V., and Duda, J.J., 2015, Large-scale dam removal on the Elwha River, Washington, USA; source-to-sink sediment budget and synthesis: Geomorphology, v. 246, p. 729-750, accessed 1/5/2020 at https://www.sciencedirect.com/ science/article/abs/pii/S0169555X15000227.

Weber, M., de Beer, D., Lott, C., Polerecky, L., Kohls , K., Abed, R.M.M., Ferdelman, T.G., and Fabricius, K.E., 2012, Mechanisms of damage to corals exposed to sedimentation: Proceedings of the National Academy of Science of the United States of America, v. 109, p. E1559, accessed 1/5/2020 at https://www.pnas.org/content/109/24/E1558.

Wentworth, C.K., 1925, The geology of Lanai: Bishop Museum Bulletin, v. 24, 72 p.
Moffett Field Publishing Service Center, California

Manuscript approved for publication on November 11, 2020

Edited by J.L. Zigler

Layout and design by JoJo Mangano 


\section{Appendix 1. Rainfall Data For West Maui}

Table 1.1. Annual totals of intense rainfalls, Lahaina, West Maui.

[mm, millimeters; $\mathrm{mm} / \mathrm{hr}$, millimeters per hour; bold, largest events]

\begin{tabular}{|c|c|c|c|c|c|c|}
\hline \multirow{2}{*}{ Water year } & \multirow{2}{*}{$\begin{array}{l}\text { Total rainfall } \\
(\mathrm{mm})\end{array}$} & \multirow{2}{*}{$\begin{array}{l}\text { Sustained } \\
\text { rainfall } \\
>20 \mathrm{~mm} / \mathrm{hr} \\
\text { (in hours) }\end{array}$} & \multicolumn{4}{|c|}{ Total hours of rainfall above intensity threshold } \\
\hline & & & $20 \mathrm{~mm} / \mathrm{hr}$ & $30 \mathrm{~mm} / \mathrm{hr}$ & $40 \mathrm{~mm} / \mathrm{hr}$ & $50 \mathrm{~mm} / \mathrm{hr}$ \\
\hline 1978 & 76 & 0 & 1.25 & 0.75 & 0.75 & 0.25 \\
\hline 1979 & 373 & 0 & 4 & 1 & 0.75 & 0 \\
\hline 1980 & 333 & 0 & 4.75 & 2 & 0.25 & 0.25 \\
\hline 1981 & 104 & 0 & 1 & 0.5 & 0 & 0 \\
\hline 1982 & 508 & 4.5 & 7.75 & 3.25 & 1.75 & 0.75 \\
\hline 1983 & 239 & 1.25 & 2.75 & 1.75 & 0.75 & 0.25 \\
\hline 1984 & 318 & 3 & 5.25 & 2.5 & 1.25 & 0.75 \\
\hline 1985 & 109 & 0 & 0.75 & 0.5 & 0.25 & 0.25 \\
\hline 1986 & 292 & 1 & 3 & 1 & 0.75 & 0.5 \\
\hline 1987 & 206 & 0 & 2.25 & 0.25 & 0 & 0 \\
\hline 1988 & 307 & 1 & 3.5 & 1 & 0.75 & 0.5 \\
\hline 1989 & 653 & 3.75 & 10.75 & 3 & 1.25 & 1 \\
\hline 1990 & 526 & 3 & 7.5 & 3.5 & 2.5 & 1.25 \\
\hline 1991 & 447 & 0 & 6.25 & 3.5 & 2 & 1.25 \\
\hline 1992 & 155 & 0 & 1.75 & 1.25 & 1 & 0.5 \\
\hline 1993 & 221 & 0 & 2.75 & 0.75 & 0.5 & 0.25 \\
\hline 1994 & 173 & 0 & 2 & 0.5 & 0.25 & 0 \\
\hline 1995 & 112 & 0 & 3.5 & 0.75 & 0.25 & 0 \\
\hline 1996 & 254 & 0 & 2.75 & 1 & 0.5 & 0.25 \\
\hline 1997 & 630 & 1.25 & 7.25 & 2.5 & 1.5 & 0.75 \\
\hline 1998 & 43 & 0 & 0.5 & 0 & 0 & 0 \\
\hline 1999 & 145 & 1.25 & 1.5 & 0.75 & 0.5 & 0.5 \\
\hline 2000 & 51 & 0 & 0.5 & 0 & 0 & 0 \\
\hline 2001 & 137 & 0 & 3.25 & 0.5 & 0.25 & 0 \\
\hline
\end{tabular}

Table 1.2. Annual totals of intense rainfalls, Puu Kolii, West Maui. See figure 9 for location.

[mm, millimeters; $\mathrm{mm} / \mathrm{hr}$, millimeters per hour]

\begin{tabular}{|c|c|c|c|c|c|c|}
\hline \multirow{2}{*}{ Water year } & \multirow{2}{*}{$\begin{array}{l}\text { Total rainfall } \\
(\mathrm{mm})\end{array}$} & \multirow{2}{*}{$\begin{array}{l}\text { Sustained } \\
\text { rainfall } \\
>20 \mathrm{~mm} / \mathrm{hr} \\
\text { (in hours) }\end{array}$} & \multicolumn{4}{|c|}{ Total hours of rainfall above intensity threshold } \\
\hline & & & $20 \mathrm{~mm} / \mathrm{hr}$ & $30 \mathrm{~mm} / \mathrm{hr}$ & $40 \mathrm{~mm} / \mathrm{hr}$ & $50 \mathrm{~mm} / \mathrm{hr}$ \\
\hline 2003 & 467 & 5.75 & 0 & 2.25 & 1.25 & 1 \\
\hline 2004 & 1,100 & 15.5 & 3.75 & 8.75 & 4 & 1.5 \\
\hline 2005 & 229 & 1.25 & 0 & 0.5 & 0 & 0 \\
\hline 2006 & 511 & 5.75 & 1.25 & 3 & 2.25 & 1.25 \\
\hline 2007 & 460 & 7 & 2.75 & 4 & 1.75 & 1.5 \\
\hline 2008 & 704 & 11.75 & 3.25 & 5.25 & 3.75 & 1.75 \\
\hline 2009 & 335 & 4 & 0 & 1.5 & 0 & 0 \\
\hline 2010 & 152 & 2.75 & 0 & 1.5 & 0.75 & 0.5 \\
\hline 2011 & 427 & 5.5 & 0 & 2.5 & 1.75 & 0.5 \\
\hline 2012 & 216 & 0.5 & 0 & 0.5 & 0 & 0 \\
\hline
\end{tabular}


Table 1.3. Annual totals of intense rainfalls, Field 28, West Maui. See figure 9 for location.

[mm, millimeters; $\mathrm{mm} / \mathrm{hr}$, millimeters per hour $]$

\begin{tabular}{|c|c|c|c|c|c|c|}
\hline \multirow{2}{*}{ Water year } & \multirow{2}{*}{$\begin{array}{l}\text { Total rainfall } \\
(\mathbf{m m})\end{array}$} & \multirow{2}{*}{$\begin{array}{c}\text { Sustained } \\
\text { rainfall } \\
>20 \mathrm{~mm} / \mathrm{hr} \\
\text { (in hours) }\end{array}$} & \multicolumn{4}{|c|}{ Total hours of rainfall above intensity threshold } \\
\hline & & & $20 \mathrm{~mm} / \mathrm{hr}$ & $30 \mathrm{~mm} / \mathrm{hr}$ & $40 \mathrm{~mm} / \mathrm{hr}$ & $50 \mathrm{~mm} / \mathrm{hr}$ \\
\hline 2006 & 1,107 & 7.25 & 0 & 5 & 3.75 & 2.5 \\
\hline 2007 & 1,100 & 8.25 & 3.75 & 3.75 & 2 & 1.25 \\
\hline 2008 & 1,580 & 17 & 2.5 & 8.25 & 4.75 & 2.75 \\
\hline 2009 & 1,295 & 7.75 & 0 & 3.25 & 1.75 & 1.25 \\
\hline 2010 & 658 & 3.25 & 1 & 1 & 1 & 1 \\
\hline 2011 & 917 & 6.5 & 1.25 & 3.25 & 1.5 & 1 \\
\hline 2012 & 1,011 & 6.75 & 2.5 & 2.25 & 1.25 & 1 \\
\hline 2013 & 470 & 1 & 0 & 0 & 0 & 0 \\
\hline
\end{tabular}

Table 1.4. Annual totals of intense rainfalls, Field 46, West Maui. See figure 9 for location.

[mm, millimeters; $\mathrm{mm} / \mathrm{hr}$, millimeters per hour]

\begin{tabular}{|c|c|c|c|c|c|c|}
\hline \multirow{2}{*}{ Water year } & \multirow{2}{*}{$\begin{array}{l}\text { Total rainfall } \\
\quad(\mathrm{mm})\end{array}$} & \multirow{2}{*}{$\begin{array}{c}\text { Sustained } \\
\text { rainfall } \\
>20 \mathrm{~mm} / \mathrm{hr} \\
\text { (in hours) }\end{array}$} & \multicolumn{4}{|c|}{ Total hours of rainfall above intensity threshold } \\
\hline & & & $20 \mathrm{~mm} / \mathrm{hr}$ & $30 \mathrm{~mm} / \mathrm{hr}$ & $40 \mathrm{~mm} / \mathrm{hr}$ & $50 \mathrm{~mm} / \mathrm{hr}$ \\
\hline 1978 & 1,290 & 10.25 & 0 & 6.25 & 6.25 & 5 \\
\hline 1979 & 2,443 & 21 & 2.25 & 12 & 9.25 & 7.25 \\
\hline 1980 & 3,449 & 31 & 1 & 13 & 9.5 & 7.25 \\
\hline 1981 & 1,191 & 8.5 & 0 & 3.5 & 2 & 1.25 \\
\hline 1982 & 3,360 & 37 & 3.75 & 15.5 & 8.75 & 6 \\
\hline 1983 & 2,017 & 17.5 & 0 & 8.5 & 5.25 & 4 \\
\hline 1984 & 1,905 & 14.75 & 1.25 & 10 & 7.25 & 5.5 \\
\hline 1985 & 1,542 & 7.25 & 0 & 2 & 1 & 0.75 \\
\hline 1986 & 2,360 & 17 & 1 & 4.25 & 1.5 & 0.25 \\
\hline 1987 & 2,060 & 25 & 6.5 & 10.25 & 6 & 3 \\
\hline 1988 & 2,530 & 17.5 & 3.25 & 6 & 3 & 1.5 \\
\hline 1989 & 2,944 & 24.25 & 4.75 & 7.75 & 5.25 & 3.25 \\
\hline 1990 & 1,727 & 8 & 1.25 & 3 & 1.25 & 0.5 \\
\hline 1991 & 2,400 & 19.5 & 3.25 & 4.5 & 1 & 1 \\
\hline 1992 & 1,372 & 7.5 & 0 & 1.25 & 0.75 & 0.25 \\
\hline 1993 & 1,890 & 14.5 & 4.5 & 4.25 & 2.5 & 1 \\
\hline 1994 & 1,262 & 6.75 & 0 & 2 & 0.75 & 0 \\
\hline 1995 & 1,293 & 8.25 & 0 & 1.25 & 0.5 & 0.25 \\
\hline 1996 & 1,562 & 11.75 & 1 & 3.25 & 1.75 & 0.75 \\
\hline 1997 & 1,725 & 15.25 & 2.5 & 3.75 & 1 & 0.25 \\
\hline 1998 & 1,443 & 7.25 & 0 & 1.25 & 0.5 & 0 \\
\hline 1999 & 940 & 7.5 & 0 & 1.25 & 0.25 & 0 \\
\hline 2000 & 968 & 6.5 & 0 & 1.25 & 0.25 & 0 \\
\hline 2001 & 841 & 2.25 & 0 & 1 & 0.5 & 0.25 \\
\hline 2002 & 892 & 5.5 & 2.75 & 3 & 2.5 & 1.25 \\
\hline 2003 & 1,384 & 13.5 & 9.25 & 5.5 & 2.75 & 1.25 \\
\hline 2004 & 1,585 & 17.5 & 7.75 & 6 & 4 & 2 \\
\hline 2005 & 1,750 & 12 & 0 & 2.5 & 0.75 & 0.25 \\
\hline
\end{tabular}


Table 1.5. Record of heaviest rainfalls over 1 hour in Lahaina, West Maui. See figure 9 for location. [mm, millimeters; $\mathrm{mm} / \mathrm{hr}$, millimeters per hour; bold, largest events; - , no data]

\begin{tabular}{|c|c|c|c|c|}
\hline \multirow{2}{*}{ Time at end of storm } & \multirow{2}{*}{$\begin{array}{c}\text { Water year total } \\
\text { rainfall at end of } \\
\text { storm }(\mathrm{mm})\end{array}$} & \multicolumn{3}{|c|}{ Durations of rainfall above intensity threshold } \\
\hline & & $20 \mathrm{~mm} / \mathrm{hr}$ & $30 \mathrm{~mm} / \mathrm{hr}$ & $40 \mathrm{~mm} / \mathrm{hr}$ \\
\hline $1 / 7 / 19826: 45$ & 30 & 1 & - & - \\
\hline $1 / 21 / 198214: 00$ & 178 & 1.75 & - & - \\
\hline 1/22/1982 5:00 & 249 & 1.75 & - & - \\
\hline $12 / 23 / 198220: 30$ & 175 & 1.25 & - & - \\
\hline $12 / 25 / 19832: 45$ & 91 & 1.75 & - & - \\
\hline 12/25/1983 5:15 & 140 & 1.25 & - & - \\
\hline $10 / 18 / 19857: 30$ & 117 & 1 & - & - \\
\hline $11 / 14 / 198718: 45$ & 56 & 1 & 1 & - \\
\hline $11 / 4 / 198814: 30$ & 74 & 1.75 & - & - \\
\hline 12/16/1988 9:00 & 292 & 1 & - & - \\
\hline $2 / 2 / 198921: 15$ & 378 & 1 & - & - \\
\hline 10/9/1989 0:45 & 142 & 1.5 & - & - \\
\hline 12/9/1989 11:45 & 292 & 1.5 & 1 & - \\
\hline 1/20/1997 1:15 & 472 & 1.25 & 1.25 & 1.25 \\
\hline $12 / 31 / 1998 \quad 7: 15$ & 74 & 1.25 & - & - \\
\hline
\end{tabular}

Table 1.6. Record of heaviest rainfalls over 1 hour in Puu Kolii, West Maui. See figure 9 for location. [mm, millimeters; $\mathrm{mm} / \mathrm{hr}$, millimeters per hour; bold, largest events; —, no data ]

\begin{tabular}{|c|c|c|c|c|}
\hline \multirow{2}{*}{ Time at end of storm } & \multirow{2}{*}{$\begin{array}{l}\text { Water year total } \\
\text { rainfall at end of } \\
\text { storm }(\mathrm{mm})\end{array}$} & \multicolumn{3}{|c|}{ Durations of rainfall above intensity threshold } \\
\hline & & $20 \mathrm{~mm} / \mathrm{hr}$ & $30 \mathrm{~mm} / \mathrm{hr}$ & $40 \mathrm{~mm} / \mathrm{hr}$ \\
\hline $1 / 1 / 200414: 15$ & 246 & 1.25 & - & - \\
\hline $1 / 3 / 20040: 45$ & 424 & 1.25 & - & - \\
\hline $3 / 22 / 20045: 15$ & 859 & 1.25 & - & - \\
\hline 3/24/2006 3:00 & 338 & 1.25 & - & - \\
\hline $10 / 16 / 20065: 30$ & 48 & 1 & 1 & - \\
\hline 11/2/2006 14:00 & 226 & 1.75 & 1.5 & - \\
\hline 11/28/2007 12:00 & 99 & 1.25 & - & - \\
\hline 12/5/2007 11:00 & 312 & 2 & 1.75 & - \\
\hline
\end{tabular}

Table 1.7. Record of heaviest rainfalls over 1 hour in Field 28, West Maui. See figure 9 for location.

[mm, millimeters; mm/hr, millimeters per hour; bold, largest events; - , no data]

\begin{tabular}{|c|c|c|c|c|}
\hline \multirow{2}{*}{ Time at end of storm } & \multirow{2}{*}{$\begin{array}{l}\text { Water year total } \\
\text { rainfall at end of } \\
\text { storm }(\mathrm{mm})\end{array}$} & \multicolumn{3}{|c|}{ Durations of rainfall above intensity threshold } \\
\hline & & $20 \mathrm{~mm} / \mathrm{hr}$ & $30 \mathrm{~mm} / \mathrm{hr}$ & $40 \mathrm{~mm} / \mathrm{h}$ \\
\hline 11/2/2006 14:30 & 221 & 1.5 & 1 & 1 \\
\hline $12 / 2 / 20067: 00$ & 389 & 1.25 & - & - \\
\hline 3/10/2007 3:00 & 709 & 1 & - & - \\
\hline 12/5/2007 11:00 & 582 & 2.5 & 2.25 & 2 \\
\hline $12 / 3 / 200923: 15$ & 251 & 1 & - & - \\
\hline 1/13/2011 4:00 & 630 & 1.25 & - & - \\
\hline $10 / 31 / 201122: 45$ & 74 & 1 & - & - \\
\hline 12/13/2011 11:15 & 345 & 1.5 & - & - \\
\hline
\end{tabular}


Table 1.8. Record of heaviest rainfalls over 1 hour in Field 46, West Maui. See figure 9 for location. [mm, millimeters; $\mathrm{mm} / \mathrm{hr}$, millimeters per hour; bold, largest events; —, no data]

\begin{tabular}{|c|c|c|c|c|}
\hline \multirow{2}{*}{ Time at end of storm } & \multirow{2}{*}{$\begin{array}{l}\text { Water year total } \\
\text { rainfall at end of } \\
\text { storm }(\mathrm{mm})\end{array}$} & \multicolumn{3}{|c|}{ Durations of rainfall above intensity threshold } \\
\hline & & $20 \mathrm{~mm} / \mathrm{hr}$ & $30 \mathrm{~mm} / \mathrm{hr}$ & $40 \mathrm{~mm} / \mathrm{h}$ \\
\hline 1/11/1979 17:30 & 513 & 1 & - & - \\
\hline 2/21/1979 5:45 & 1,328 & 1.25 & - & - \\
\hline 3/16/1980 17:45 & 1,714 & 1 & - & - \\
\hline 1/25/1982 5:30 & 1,135 & 1 & - & - \\
\hline $2 / 11 / 19826: 15$ & 1,420 & 1.5 & 1.5 & - \\
\hline 8/1/1982 10:15 & 2,962 & 1.25 & - & - \\
\hline $12 / 25 / 19836: 30$ & 737 & 1.25 & - & - \\
\hline 3/19/1986 22:45 & 1,052 & 1 & - & - \\
\hline $11 / 10 / 19867: 30$ & 272 & 2.75 & 2 & - \\
\hline 5/5/1987 18:15 & 1,344 & 1.25 & 1.25 & - \\
\hline 5/6/1987 4:15 & 1,438 & 1 & - & - \\
\hline $5 / 6 / 198710: 45$ & 1,524 & 1.5 & - & - \\
\hline 1/1/1988 8:00 & 922 & 2 & 1.25 & 1.25 \\
\hline 4/3/1988 6:15 & 1,778 & 1.25 & - & - \\
\hline 12/16/1988 9:45 & 424 & 1.5 & - & - \\
\hline 2/2/1989 21:30 & 859 & 1 & - & - \\
\hline 4/5/1989 3:15 & 1,471 & 2.25 & - & - \\
\hline $12 / 9 / 198911: 45$ & 274 & 1.25 & - & - \\
\hline $11 / 19 / 19902: 30$ & 488 & 1 & - & - \\
\hline $12 / 24 / 19901: 45$ & 871 & 1 & - & - \\
\hline 9/19/1991 13:00 & 2,388 & 1.25 & - & - \\
\hline $12 / 31 / 19921: 45$ & 640 & 1.25 & - & - \\
\hline 7/22/1993 15:15 & 1,537 & 1.75 & 1.25 & 1.25 \\
\hline 7/22/1993 19:45 & 1,590 & 1.5 & - & - \\
\hline 3/30/1996 23:15 & 1,016 & 1 & - & - \\
\hline 12/14/1996 4:00 & 348 & 1 & 1 & 1 \\
\hline 1/4/1997 10:15 & 668 & 1.5 & - & - \\
\hline $11 / 27 / 20017: 15$ & 381 & 1.5 & 1.25 & - \\
\hline 5/13/2002 5:15 & 617 & 1.25 & 1 & 1 \\
\hline $10 / 15 / 2002$ 7:00 & 81 & 1.5 & 1.25 & - \\
\hline $1 / 24 / 200322: 30$ & 419 & 1 & - & - \\
\hline $1 / 29 / 200323: 15$ & 505 & 1.5 & - & - \\
\hline $1 / 30 / 20034: 30$ & 554 & 1 & - & - \\
\hline 2/14/2003 8:45 & 732 & 4.25 & - & - \\
\hline $12 / 25 / 200314: 00$ & 175 & 1.25 & 1 & - \\
\hline $12 / 25 / 2003 \quad 16: 15$ & 226 & 1.5 & 1 & - \\
\hline $2 / 27 / 200420: 30$ & 419 & 1 & - & - \\
\hline $2 / 27 / 200423: 30$ & 478 & 1.5 & - & - \\
\hline $3 / 22 / 200419: 45$ & 937 & 2.5 & - & - \\
\hline
\end{tabular}




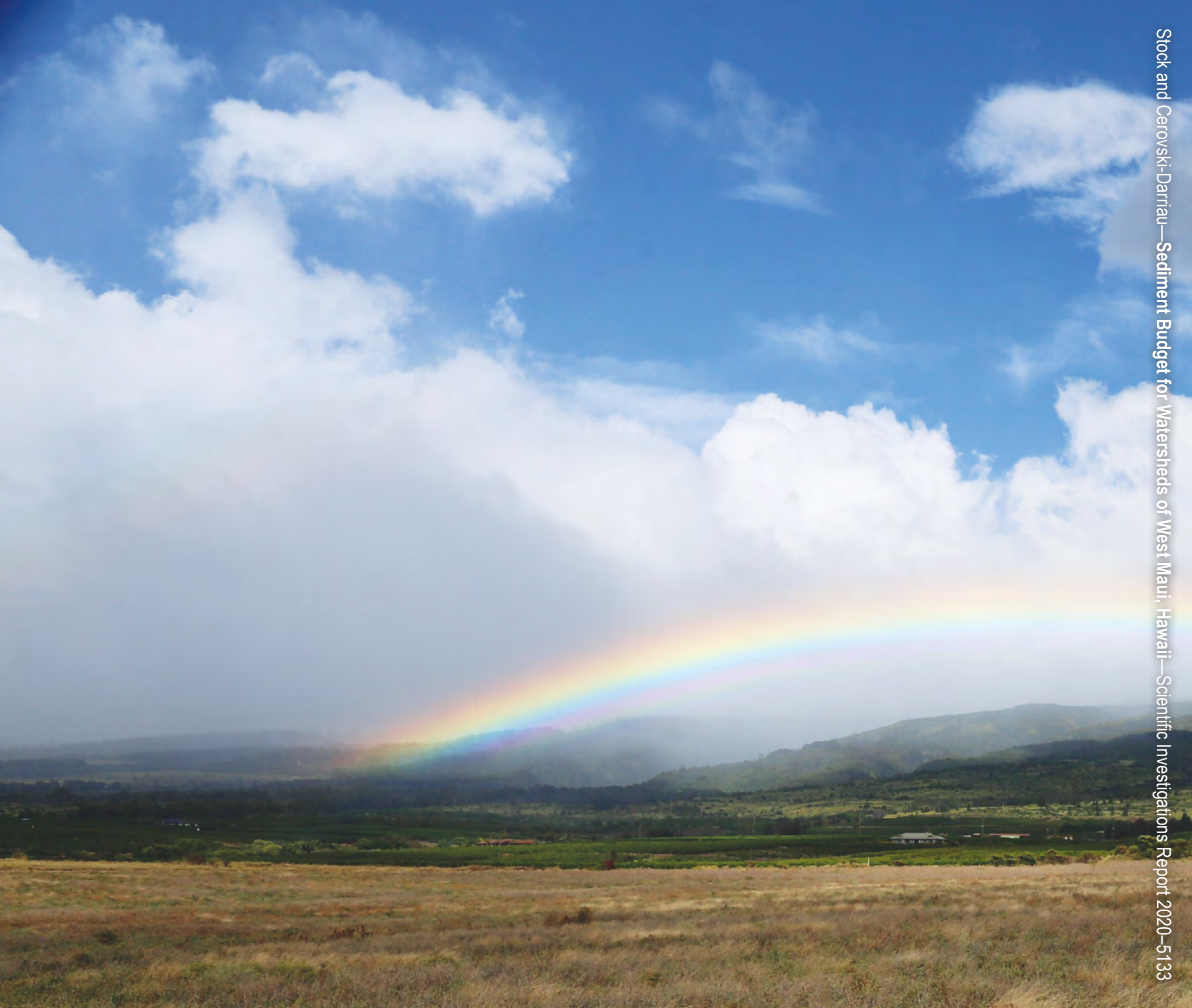
25.

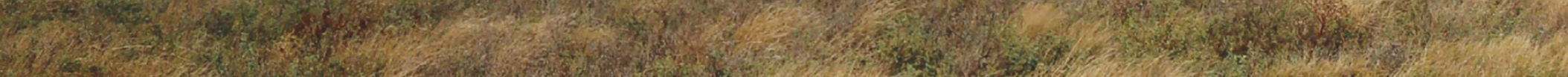

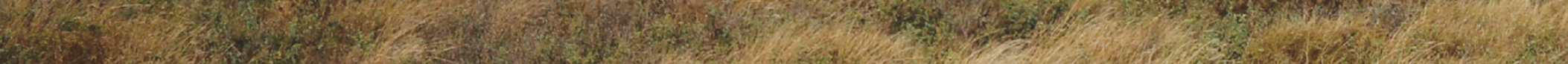

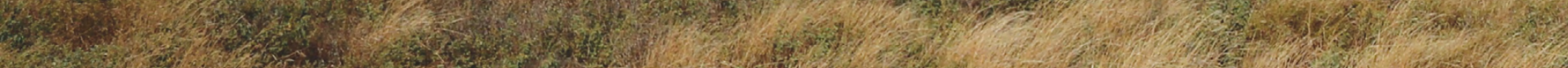

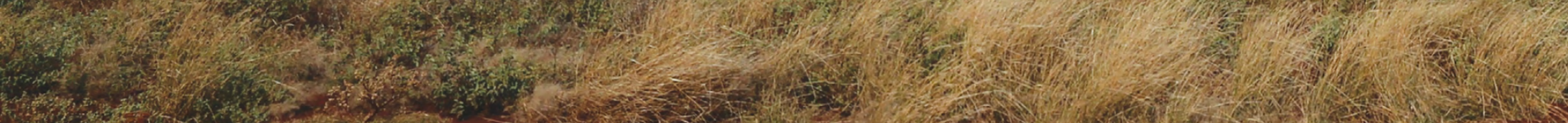
19.6.

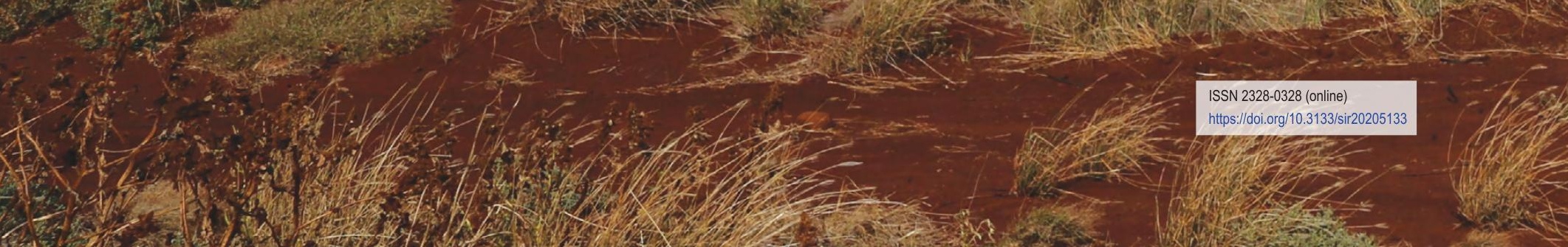

